University of Louisville

ThinkIR: The University of Louisville's Institutional Repository

$5-2015$

\title{
Hidden sites of 'first-year' composition : what do we mean when we say 'AP'? : the diversity of practices in AP English language and composition courses.
}

Hollye Nicole Wright

University of Louisville

Follow this and additional works at: https://ir.library.louisville.edu/etd

Part of the Rhetoric and Composition Commons

\section{Recommended Citation}

Wright, Hollye Nicole, "Hidden sites of 'first-year' composition : what do we mean when we say 'AP'? : the diversity of practices in AP English language and composition courses." (2015). Electronic Theses and Dissertations. Paper 2090.

https://doi.org/10.18297/etd/2090

This Doctoral Dissertation is brought to you for free and open access by ThinkIR: The University of Louisville's Institutional Repository. It has been accepted for inclusion in Electronic Theses and Dissertations by an authorized administrator of ThinkIR: The University of Louisville's Institutional Repository. This title appears here courtesy of the author, who has retained all other copyrights. For more information, please contact thinkir@louisville.edu. 
HIDDEN SITES OF 'FIRST-YEAR' COMPOSITION: WHAT DO WE MEAN WHEN WE SAY 'AP'? THE DIVERSITY OF PRACTICES IN AP ENGLISH LANGUAGE AND COMPOSITION COURSES

\author{
By \\ Hollye Nicole Wright \\ B.A., University of Louisville, 2006 \\ M.A.T., University of Louisville, 2008 \\ M.A., University of Louisville, 2010
}

\begin{abstract}
A Dissertation
Submitted to the Faculty of the

College of Arts and Sciences of the University of Louisville in Partial Fulfillment of the Requirements

for the Degree of
\end{abstract}

Doctor of Philosophy in English/Rhetoric and Composition

Department of English

University of Louisville

Louisville, Kentucky

May 2015 
Copyright 2015 by Hollye Nicole Wright

All rights reserved 

HIDDEN SITES OF 'FIRST-YEAR' COMPOSITION: WHAT DO WE MEAN WHEN WE SAY 'AP'? THE DIVERSITY OF PRACTICES IN AP ENGLISH LANGUAGE AND COMPOSITION COURSES

\author{
By \\ Hollye Nicole Wright \\ B.A., University of Louisville, 2006 \\ M.A.T., University of Louisville, 2008 \\ M.A., University of Louisville, 2010 \\ A Dissertation Approved on
}

March 9, 2015

by the following Dissertation Committee:

Dissertation Director, Bronwyn T. Williams

Mary P. Sheridan

Brenda Jo Brueggemann

Debra Journet

Dottie Willis 


\section{ACKNOWLEDGEMENTS}

I would like to thank my director, Bronwyn Williams, for his guidance, support, and encouragement throughout this project. I would also like to thank my committee: Mary P. Sheridan, Brenda Brueggemann, Debra Journet, and Dottie Willis for their insight, feedback, and patience throughout this process. Several other professors also deserve special thanks for the support they provided throughout my time at $\mathrm{U}$ of $\mathrm{L}$ : Tamara Yohannes, Joanna Wolfe, Matthew Biberman, and Stephen Schneider.

Thanks particularly to the participants of this project. The generosity of the teachers who welcomed me into their classrooms and shared their time and experiences made this project a reality. And, a special thanks to the many students that welcomed me into their classrooms and shared their experiences in AP English Language and Composition with me.

I would also like to thank the friends and colleagues that helped shape this project along the way: Caroline Wilkinson, Laura Detmering, Susannah Kilbourne, Kristin Vukmanic, Rob Detmering, Rachel Gramer, and Steve Cohen. Thank you for spending countless hours helping me develop ideas, review drafts, and for your continued support and friendship.

Finally, a special thanks to my family. This dissertation was able to become a reality through your love and support. 


\begin{abstract}
HIDDEN SITES OF 'FIRST-YEAR' COMPOSITION: WHAT DO WE MEAN WHEN

WE SAY ‘AP’? THE DIVERSITY OF PRACTICES IN AP ENGLISH LANGUAGE

AND COMPOSITION COURSES

Hollye Nicole Wright

March 9, 2015
\end{abstract}

This dissertation responds to recent conversations on college readiness and precollege credit for writing alternatives. Specifically, this dissertation investigates the ways in which dispositions associated with college readiness are fostered within AP English Language and Composition courses at multiple locations within a single school district and illustrates the intersections between AP English Language and Composition and first-year writing at different locations to highlight the diversity of practices within AP English Language and Composition.

Chapter one traces the histories and intersections of AP English Language and Composition and first-year writing. Chapter two describes the research methods utilized in this study. Chapter three examines the ways in which policies associated with AP English Language and Composition encourage learning environments focused on developing the dispositions identified in the Framework for Success in Postsecondary Writing. Chapter four explores the literacy experiences occurring in four AP English Language and Composition classes and the ways in which these experiences relate to 
dispositions identified in the Framework for Success in Postsecondary Writing. Chapter five provides a case study of AP English Language and Composition at Violet Fields High School and finds that the course is effectively serving as a site of first-year writing. Chapter six provides a case study of AP English Language and Composition at Blue Meadows High School and finds that, while the course is challenging, meets the outcomes outlined by the College Board, and covers a variety of material, this course lacks essential elements needed for it to successfully function as a site of first-year writing. Chapter seven provides a case study of AP English Language and Composition at Red River High School and finds the course functioning as a site of first-year writing and as a site of college preparation as the result of efforts to increase enrollment in AP courses through participation in Advance Kentucky. The conclusion addresses implications of the findings of this project for secondary and postsecondary teachers of writing in regards to policy and pedagogy in AP English Language and Composition. 


\section{TABLE OF CONTENTS}

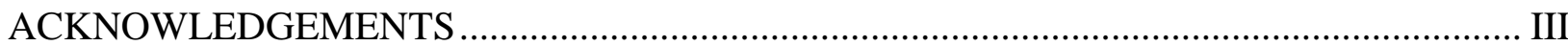

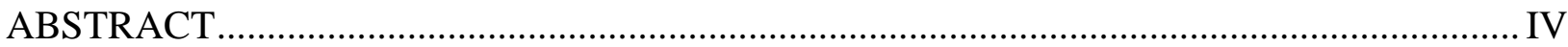

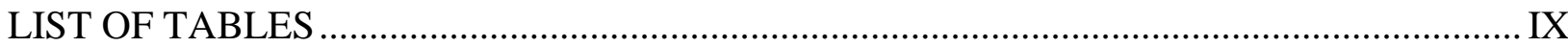

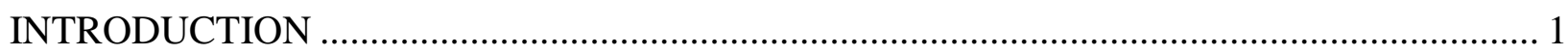

CHAPTER 1: HISTORIES AND INTERSECTIONS: FIRST-YEAR WRITING AND

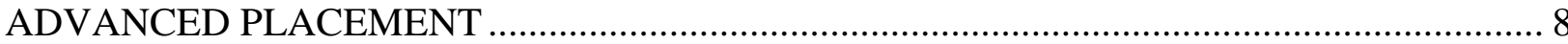

The Development of First-Year Writing ………………............................................ 8

The Development of Advanced Placement English......................................................... 10

AP English Responds: The Evolving AP English Language and Composition Course 15

WPA OS History and Development .......................................................................... 16

WPA OS and Precollege Credit for Writing Alternatives ........................................... 19

Tensions Between Advanced Placement English and First-Year Writing..................... 21

Responses from Rhetoric and Composition: Growing Attention to Precollege Credit for

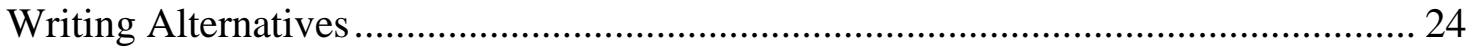

Frameworks for Considering Literacy, Advanced Placement English, and First-Year

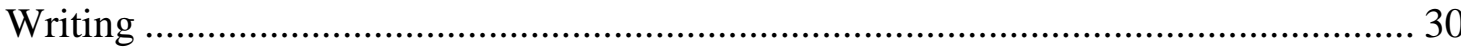

Actor-Network Theory as Heuristic for Examining the Connections Between AP English Language and Composition and First-Year Writing........................................ 37

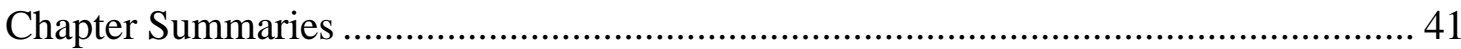

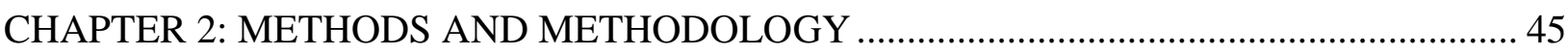

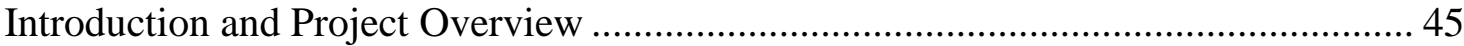

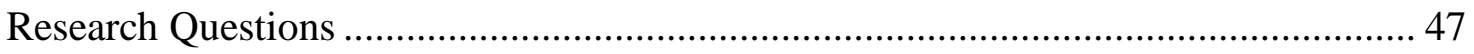

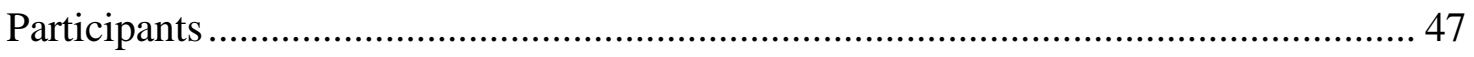

Methods and Methodology...................................................................................... 55

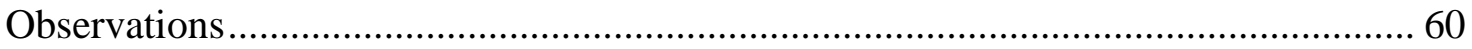




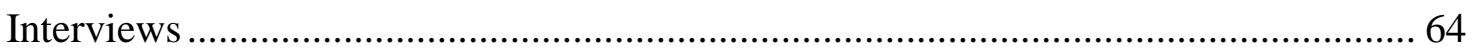

Survey

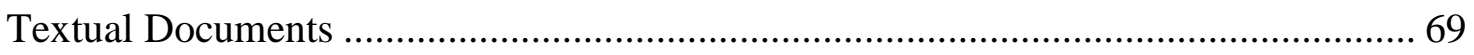

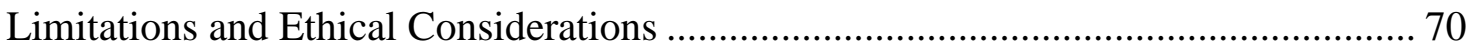

CHAPTER 3: COLLEGE READINESS, THE FRAMEWORK FOR SUCCESS IN POSTSECONDARY WRITING, AND AP ENGLISH LANGUAGE AND COMPOSITION

College Readiness and Advanced Placement................................................................ 77

The Framework for Success in Postsecondary Writing ............................................... 83

AP English Language and Composition Preparing Students for Postsecondary Writing 91

Dispositions and AP English Language and Composition Outcomes .......................... 97

Conclusions 107

CHAPTER 4: CULTIVATING DISPOSITIONS THROUGH LITERACY EXPERIENCES: AP ENGLISH LANGUAGE AND COMPOSITION AND COLLEGE READINESS

AP English Language and Composition: An Investigation of Four Courses.............. 112

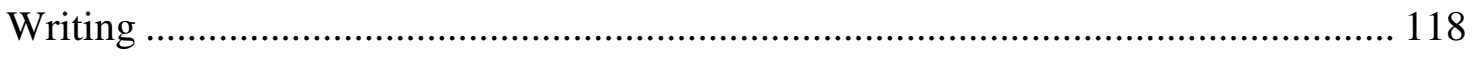

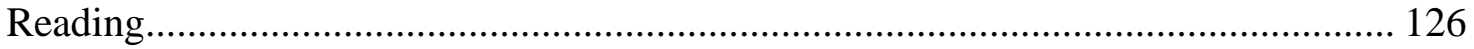

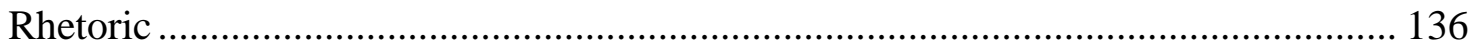

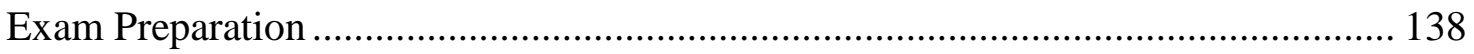

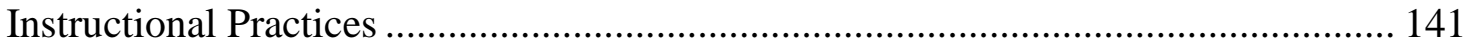

Cultivating Dispositions for College Readiness: The Framework for Success in Postsecondary Writing and AP English Language and Composition........................ 142

AP English Language and Composition and Literacy : A Few Concerns ................... 149

Conclusions 152

CHAPTER 5: EXCEPTIONAL CONSTRUCTIONS OF AP ENGLISH LANGUAGE AND COMPOSITION: A LOOK AT ONE TEACHER'S PRACTICE AND PHILOSOPHY

AP English Language and Composition at Violet Fields High School....................... 155

Instructional Approach and Teaching Philosophy ……………………………….... 158

The Unit: Keys to Successful College Writing ......................................................... 170

Writing Instruction .......................................................................................... 180 
The Researched Argument Paper and First-Year Composition Outcomes................ 189

Conclusions

CHAPTER 6: TRADITIONAL CONSTRUCTIONS OF AP ENGLISH LANGUAGE AND COMPOSITION: THE STORY OF ONE TEACHER'S INSTRUCTIONAL APPROACH

AP English Language and Composition at Blue Meadows High School 197

Instructional Practices 199

Student Perceptions .......................................................................................... 216

Conclusions 219

CHAPTER 7: INNOVATIVE CONSTRUCTIONS OF AP ENGLISH LANGUAGE AND COMPOSITION: PRECOLLEGE CREDIT FOR WRITING AND PREPARATION FOR COLLEGE READINESS

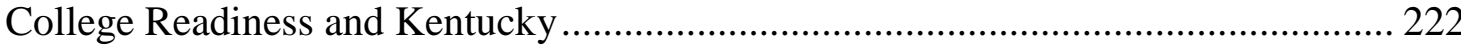

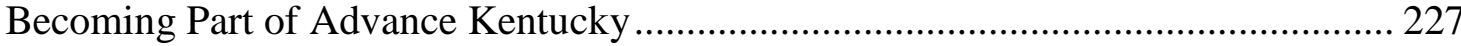

Reading and Writing in AP English Language and Composition............................. 238

Rhetoric in AP English Language and Composition ............................................. 264

Students' Perceptions About Writing In Postsecondary Education ........................... 266

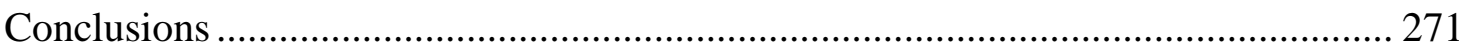

CONCLUSION: INVESTIGATING PRACTICES IN AP ENGLISH LANGUAGE AND COMPOSITION LEADS TO REIMAGINING POSSIBILITIES

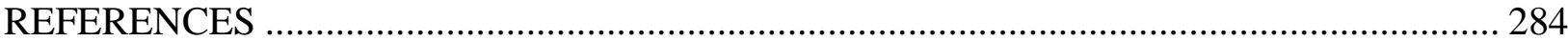

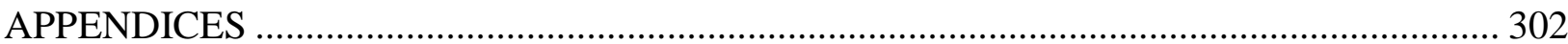

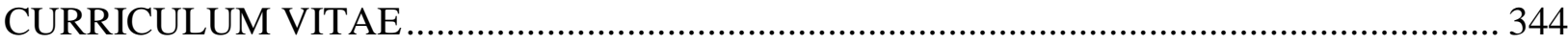




\section{LIST OF TABLES}

Table 1: WPA OS \& AP English Language and Composition Outcomes ....................... 95

Table 2: Curiosity \& AP English Language and Composition Outcomes........................ 98

Table 3: Openness \& AP English Language and Composition Outcomes ..................... 100

Table 4: Engagement \& \& AP English Language and Composition Outcomes ............ 100

Table 5: Creativity \& AP English Language and Composition Outcomes ................... 101

Table 6: Persistence \& AP English Language and Composition Outcomes ................... 103

Table 7: Responsibility \& AP English Language and Composition Outcomes ............. 104

Table 8: Flexibility \& AP English Language and Composition Outcomes................... 105

Table 9: Metacognition \& AP English Language and Composition Outcomes ............. 106

Table 10: Warm-Up: Vocabulary/Grammar/Usage Question Examples....................... 200

Table 11: Warm-Up: Word of the Day Examples ...................................................... 203

Table 12: Warm-Up Quote of the Day Examples...................................................... 204

Table 13: Warm-Up Big Question Examples ........................................................... 206 


\section{INTRODUCTION}

"In most institutions, college composition, the course for which the AP English Language and Composition Exam is designed to test for exit-level proficiency, is a class where students begin to work in earnest to achieve two goals: to succeed as independent readers, writers, and thinkers in courses throughout the curriculum, and to function as literate, responsible citizens in their lives outside the walls of academia." (Teacher's Guide 3)

David A. Jolliffe

In the opening quotation, from the AP English Language and Composition Teacher's Guide, David A. Jolliffe summarizes the goals of first-year composition by focusing on the skills and dispositions that first-year composition courses strive to develop. The skills associated with reading, writing, and thinking are brought to the forefront because it is through the development of these skills that students are also able to develop important dispositions that allow them to undertake these tasks independently and experience success. Students have the opportunity to develop skills and dispositions when they are presented with challenging and rigorous tasks, such as the tasks they are asked to complete in first-year writing courses and in AP English Language and Composition courses. While the first goal explicitly links with experiences tied to the WPA Outcomes Statement for First-Year Writing and AP English Language and Composition outcomes, the abstract nature of the second goal takes students outside of the space of the first-year writing course and relies not so much on skills but on dispositions that will equip students to experience success outside the classroom and 
away from outcomes. In this second goal, Jolliffe is drawing attention to the multiple and complex layers of learning that first-year composition courses have the potential to foster. Implicitly, Jolliffe is drawing attention to the relationship between the development of skills and the development of dispositions and the fact that students need to develop both in order to experience lasting success.

Contrary to the complex goals that Jolliffe identifies in the opening quotation, too frequently first-year composition becomes the victim of negative attitudes that designate the course and the content covered as remedial work, and this attitude is often perpetuated through precollege credit for writing alternatives that encourage students to complete the first-year writing requirement while they are enrolled in high school. Daniel Mahala and Michael J. Vivion explain that with AP English "students are understanding undergraduate 'English' as one of the easiest subjects to 'test out of' in the university...[and] this trivialized view of writing is encouraged by the structure of the AP English program and its promotional literature" (46). On a similar note, David Jolliffe and Bernard Phelan point out that "[b]ecause many parents, students, school administrators equate college writing instruction solely with freshman English, stakeholders in all these categories tend to see AP English as a method to avoid college writing rather than as a means to place into a writing course that is appropriately challenging for a student's level of reading and writing ability" (italics original 95). Kristine Hansen also points out that precollege credit writing alternatives "are often marketed to students and their parents as a way to 'take care of' the college writing requirement or 'get it out of the way' while the students are still in high school" (2). While there is concern among scholars in Rhetoric and Composition that AP English, and 
other alternatives to first-year writing, continue to spread the stereotype that first-year writing courses are remedial, the recent development of some educational initiatives, such as Advance Kentucky, broadens the function of AP English to focus on preparing students to enter postsecondary institutions. So, not only do scholars in Rhetoric and Composition have a concern about AP English associating negative remedial attitudes about first-year writing, they must also begin to investigate new ways that AP English is being repurposed as a means for preparing students to enter postsecondary institutions prepared to enroll in first-year writing courses.

Helping students transition from writing in high school to writing in college should be a shared enterprise between secondary and postsecondary teachers of writing. The call in existing scholarship in Rhetoric and Composition for increased conversations between secondary and postsecondary teachers of writing also is important when discussing precollege credit for writing and AP English. Collaboration between educational levels aligns with Eli Goldblatt's concepts of "deep alignment" and his extension of Deborah Brandt's conception of "literacy sponsorship." Goldblatt's work on "deep alignment" and "literacy sponsorship" provide ways of looking at the practices of AP English Language and Composition that take into consideration the institutional and structural differences inherent in the ways in which AP English Language and Composition functions as a site of first-year writing because of its physical location within high school curriculum and ideologies, and this dissertation begins to show the differing experiences that students coming out of AP English Language and Composition experience.

\footnotetext{
${ }^{1}$ By "deep alignment" Goldblatt means "a connection between institutions that goes beyond articulation agreements and the automatic acceptance of course equivalencies" (96).
} 
Further aligning with Goldblatt's concept of "deep alignment" is the call for increased communication between secondary and postsecondary teachers of writing that is found in the scholarship and echoed by the secondary teachers participating in this project. Henry, a teacher of AP English Language and Composition, explains,

Dear lord we need the dialogue [with postsecondary teachers of writing] but I'm telling you that's not the conversation going on right now. The conversation is nothing but...[increasing performance on standardized assessments]...[But we] are trying our best to align to what college wants. And quite frankly some of it is a very educated guess. We are not receiving that direction. And the district, quite frankly, from what the state is putting on them, the district really does not have time to have that conversation at this point. So, we really need it from UL, UK and Bellarmine. We need that type of direction. You guys are busy too though, I understand. (Interview 10 March 2014)

Henry laments the lack of communication between writing teachers at the secondary and postsecondary level locally and implicitly draws attention to larger issues-particularly, the pressure to increase the number of students meting college readiness benchmarks on standardized assessments-occupying conversations about education at the school, district, state, and national level. Stella, another AP English Language and Composition teacher, tells a similar story. She explains, "teachers, down to the teacher level, as much as we may want to do that [collaborate with postsecondary teachers of writing] we are constantly given more things to do and no time or compensation for them. We just don't have time to do that" (Interview 13 March 2014). Conversations with many secondary 
teachers indicated that high school teachers of writing are interested in the skills and practices that students will be asked to demonstrate in first-year writing courses. However, at the same time, current conversations about preparing students for postsecondary education are focused in other areas, such as meeting college readiness benchmarks. Therefore, the state and district levels are not providing a platform to support these types of collaborative conversations.

As more and more students are experiencing AP English Language and Composition, it is especially important that writing program administrators and instructors of first-year writing courses have an awareness of where students are coming from and where they are going in order to build on the literacies students already have and help cultivate the literacies that they may need in the future. This means that postsecondary teachers of writing need to understand the writing experiences occurring in high school and the ways in which these experiences sponsor literacy. Teachers and administrators also need to have a deeper understanding of what it means to grant firstyear writing credit for AP English Language and Composition.

My dissertation enters into conversations about precollege credit for writing and college readiness by investigating the ways in which AP English Language and Composition cultivates skills and dispositions associated with postsecondary success at the institutional level through the outcomes and documents distributed by the College Board. My dissertation also examines practices occurring at the local level through investigating documents distributed by teachers at individual schools as they construct what AP English Language and Composition means at their particular location. Through my analysis I will demonstrate the ways in which AP English Language and Composition 
works through outcomes and practices to cultivate dispositions in students that have the potential to assist them in postsecondary education. This dissertation also begins to address the diversity within AP English Language and Composition through the exploration of three AP English Language and Composition courses. It is important to understand the wide range of diversity present in AP English Language and Composition based on the individual location, school history, resources available, experiences of the teacher, and background and future goals of the students. This investigation also examines the practices associated with these courses and the similarities and differences each location has with the goals of first-year writing because it is important to understand the different writing experiences that student bring to postsecondary education and the ways in which these experiences are similar to and different from the experiences fostered in first-year writing courses.

Informed by literacy studies and actor-network theory, this project investigates the hidden sites of first-year writing that occur in AP English Language and Composition courses and considers the differences between AP English Language and Composition at multiple locations within a single school district. At a time when the AP program is expanding, my study indicates that there is no singular AP English Language and Composition experience, as is represented by the dual purposes that AP English Language and Composition serves as it operates as a site of first-year writing for students traditionally served by AP and as a site of college preparation for students traditionally excluded from AP courses. Because it is important to view each course from multiple perspectives and consider classroom practices, this project investigates the multiple purposes of AP English Language and Composition through a combination of classroom 
observations at two high schools, interviews with five AP English Language and Composition teachers, thirty three student interviews, and course documents provided by the College Board and participating teachers.

The following chapter explores the development of first-year writing courses and the origins of the AP program in order to investigate the ways in which the two have come to be associated as sites of first-year writing and preparation for college. The chapter also addresses the ways in which AP English courses have evolved based on the development of the WPA Outcomes Statement for First-Year Composition. The chapter then moves to examining the tensions that exist between first-year writing and AP English and precollege credit for writing alternatives. This chapter concludes by addressing relevant theoretical material from literacy studies and actor-network theory. 


\section{CHAPTER 1: HISTORIES AND INTERSECTIONS: FIRST-YEAR WRITING AND ADVANCED PLACEMENT}

\section{The Development of First-Year Writing}

Before precollege credit for writing can be successfully discussed, it is important to recognize the historical origins of the first-year writing class because many of the alternative programs aiming to fulfill first-year college writing can be connected to its origins. According to James Berlin, the history of first-year writing can be traced back to Harvard in 1874. Because so many prospective students were unable to pass the entrance exam, Harvard instituted a required freshman English course in 1879. This course was considered remedial material that students should have mastered by the time they entered college. Berlin contends that this change reflected a change in demographics whereby students were no longer only coming from elite families. Because this early model of first-year writing based itself on remediation and providing the needed skills to a rising middle class, current-traditional rhetoric blossomed as a skills based pedagogy focusing on "superficial correctness — spelling, punctuation, usage, syntax — and on paragraph structure" and on the modes of discourse (Berlin 38). Within this early system of firstyear writing, the first-year writing course was seen as a way for colleges to supplement what students were supposed to be learning in high school.

While Berlin argues that first-year writing arose out of a need for remediation, Robert Connors argues "that composition-rhetoric... is based in very deep cultural changes in nineteenth century America" that include postsecondary institutions enrolling 
a rising middle class population in preparation for professional and managerial careers and the influx of women entering postsecondary institutions (24). In addition, Connors contends that the first-year writing course developed before the discipline, even though "college courses of study have traditionally emerged from the accumulation of a body of knowledge, which is gradually formalized and finally developed to the point where it produces experts who can teach it" (7-8). The history of first-year writing that Connors presents positions the first-year course as a response to the changing types of employment and enrollment demographics.

Even though Berlin and Connors present histories with slightly different emphases, the creation of the course at Harvard in 1879 to deal with remediation and the changes that resulted from cultural shifts during the nineteenth century continue to be seen in how some stakeholders view the goals and purposes of first-year writing, as is noted in the introduction. Such a view of the first-year course has influenced attitudes about where and how the course should be taught. Because capable students have the opportunity to "take care of" their first-year writing requirement while still enrolled in high school, first-year writing is viewed by some as material for the developmentally appropriate high school junior or senior. This tradition of avoidance can be traced back to the association of first-year writing with remediation and works to locate it as a course for developmentally ready high school students. This tradition also contributes to the development and growth of alternative precollege credit for writing courses that students have the opportunity to complete while still enrolled in high school. However, recent programs, such as Advance Kentucky, work against the attitude that first-year writing is 
associated with remediation and, instead, foster an attitude associated with preparation for college.

\section{The Development of Advanced Placement English}

Since their creation in 1954 by the College Board as a way for advanced students to begin work on college-level material while enrolled in high school, AP courses have continued to increase in popularity. The College Board states that 2.9 million students took one or more of their 34 AP exams with the hopes of receiving some form of college credit in 2013. Even though the AP program was originally conceived as an instructional and assessment program for a small minority of exceptionally gifted students, currently students of all academic levels are permitted and encouraged to enroll in AP courses. This change has resulted from the combination of rising college costs and the association of the AP program with rigor, challenge, and academic excellence in the larger culture. Because of this change, more and more students are attempting to bypass important firstyear college courses by gaining the appropriate score from an AP exam. As the number of students participating in AP courses increases, more scholarly attention turns to the skills and practices associated with these courses and subsequent exams (The College Board). In Jefferson County Public Schools in Louisville, Kentucky this increase translates into 6,237 students enrolled in at least one AP course during the 2012-2013 school year with a total of 8,043 AP exams taken and 3,841 students scoring a three or higher on those exams (JCPS Data Book-2013 Advanced Placement Results). The AP program is especially successful in enrolling students in one of its two AP English courses - AP Literature and Composition and AP Language and Composition- because students earning a high enough score have the potential to earn credit for the first-year college writing requirement. For example, students entering the University of Louisville 
have the opportunity to earn English 101: Introduction to College Writing credit by earning a score of a 3 on either one of the AP English exams and have the opportunity to earn English 102: Intermediate College Writing credit for a score of a 3, 4, or 5 on either one of the AP English exams. However, beginning in Fall 2015, the University of Louisville will adjust this policy to better reflect the commonalities among the AP English course offerings and the English courses offered by the university. At this point, students scoring a 3, 4, or 5 on the AP English Language and Composition exam will be awarded credit for English 101: Introduction to College Writing. Credit will no longer be awarded for English 102: Intermediate College Writing. And, students scoring a 3, 4, or 5 on the AP English Literature and Composition exam will be awarded credit for English 250: Introduction to Literature. Credit will no longer be awarded for first-year writing based on exam scores from the AP English Literature and Composition exam. This change reflects a change in the curriculum of the courses and an attempt to better align precollege credit for writing with the curriculum of postsecondary course offerings with the goal of better supporting students in their transition from high school to college writing.

The AP program originated out of a perceived need to challenge advanced high school students, while first-year writing courses originated out of a perceived need for remediation. David Chalmers asserts that the AP program was developed to "offer an opportunity and a challenge to the best schools and the most able and ambitious" students (309). David Foster contends, similar to Chalmers, that the AP program was originally intended "to give better high school students more challenging work" (3). Joseph Jones agrees with Chalmers and Foster. He asserts that AP started out of a concern that "the 
'best' students were not being challenged and advanced as quickly as they should be" (43) and the AP program was seen as a solution to the "problem of talented students languishing in redundant general education courses" (52). Originally conceived as a training ground for elite students that would enter prestigious postsecondary institutions, AP courses provided educational opportunities for select groups of students that would position them ahead of "redundant general education courses".

For the most part, the ideas of prestige, challenge, and rigor continue to position students enrolled in AP courses as superior to the general population of entering first-year college students and thus capable of completing general education courses required by postsecondary institutions while still enrolled in high school. Although AP focuses on rigor, there is also a push to increase enrollment numbers in AP courses in many secondary schools. The call for greater access to the rigor associated with AP increases the number of students enrolled in these courses. However, while additional students experience the benefits associated with AP coursework, these students do not necessarily pass the AP exam, although they benefit in other ways, such as increases scores used to measure college readiness benchmarks.

Although the founding principles of AP English differ greatly from the founding principles of first-year composition, AP English has developed into a site of first-year writing instruction through the granting of college credit for scores on AP English exams and based on the attitude that the remedial work of first-year composition would not be needed for the brightest students who would enroll in AP English. Despite the fact that AP English and first-year writing developed with different purposes and intentions, overtime they have crossed paths and become intertwined with recent educational 
initiatives. For example, Advance Kentucky is a program that began in 2007 as part of the National Math Science Initiative "to work with local, state and national partners to dramatically expand access to and participation and success in rigorous college-level work in high school, particularly among student populations traditionally underrepresented in these courses" (Advance Kentucky). Through this program, students not typically served by the AP program are actively encouraged and provided the support needed to enroll and complete AP courses. This means that the very students that were once in need of remediation are being served by the AP program that was created to challenge gifted students through the Advance Kentucky initiative. The implementation of this initiative is potentially influencing the pass rate for Jefferson County Public Schools in Louisville, Kentucky. For example, Jefferson County Public Schools in Louisville, Kentucky reported that 7,762 AP exams were taken in 2012 with a pass rate of $49.7 \%$. In 2013 they reported that 8,043 AP exams were taken with a pass rate of 47.9\%. This means that the pass rate dropped 1.9\% (JCPS High School Data Book). However, a few schools in the district were participating in Advance Kentucky during this time.

Innovative initiatives in education, such as Advance Kentucky, alter and expand the purpose of AP courses because they seek to repurpose the traditional aims of the program and serve a wider and more academically diverse student population. Part of the reason students experience success can possibly be attributed to structure of the program. The program is structured under a ten-part organization that is "integrated into a holistic strategy focused on student access, engagement, and success" (Advanced Kentucky). The largest difference to AP courses under this program is the expanded enrollment 
opportunities that students are offered. The Advance Kentucky program and its effect on AP English Language and Composition will be addressed in more detail in chapter seven. While Advance Kentucky largely receives positive reception, critiques exist that question encouraging underprepared students to enroll in AP courses. As Phillip M. Sadler points out,

The disparity in educational attainment between students of high and low economic status and among different racial and ethnic groups is a national concern. Social equity is also a stated concern of the College Board...Closing the achievement gap by equalizing educational opportunity can allow students to fulfill their potential, thereby loosening the bonds of intergenerational poverty and increasing productivity. Providing access to advanced coursework to as many high school students as possible is seen by many as a way to make this happen. However, one must keep in mind that inequities in educational opportunity are cumulative. Disadvantages in the educational experience from early grades on...cannot be ameliorated by simply making advanced courses available in high school (Lee \& Burkham, 2002). While well-prepared students may benefit from college-level classes, others may be lost in such classes or alienated by the subject or may slow down other students' progress. (8-9)

As Sadler indicates, there are many concerns when expanding enrollment of advanced programs with the goal of increasing student achievement and teachers must be equipped with the material resources and institutional support to effectively include nontraditional 
AP students in AP courses. As the case study in chapter seven demonstrates, Advance Kentucky attempts to address some of these concerns.

\section{AP English Responds: The Evolving AP English Language and Composition Course}

Although AP English and first-year writing have their origins in different

traditions and sometimes seek to assist different types of students in preparation for college, the AP English Language and Composition course has demonstrated an active desire to become more closely aligned with first-year composition over the years. Because of diverse approaches to first-year composition in colleges and universities, the AP program developed a second AP English course in 1980. As Kathleen M. Puhr explains, "[t]he English Language course was created due to changes in the college composition course, primarily the movement away from writing about literature" (70). She explains that " $[\mathrm{t}]$ he AP English Literature remains a course concerned with literary comprehension and interpretation," while "AP Language and Composition is becoming a rhetoric course, designed to provide high school students with a curriculum closely aligned with a college composition course" (Evolution 68). In the AP English Language and Composition course, according to Puhr, "students learn how to analyze, synthesize, and evaluate nonfiction texts" (Teachers Guide 1). This course developed in response to changes occurring in first-year writing and continues to respond to developments in the field. The first instance of this response is the implementation of the second course, and, perhaps more important, in changes this course has undergone over the past 10 years, changes that seem to be a result of the publication of the Council of Writing Program Administrators WPA Outcomes Statement for First-Year Composition. Puhr comments that "the major climate change that precipitated the recent, rapid evolution of the AP English Language course occurred in 2002, when representatives from the AP English 
Test Development Committee along with an experienced AP teacher met with writing program administrators at the WPA conference" (73). This meeting led to changes that resulted in the AP English Language and Composition course and exam being focused on analysis, synthesis, and argument.

\section{WPA OS History and Development}

The changes to AP English Language and Composition were set into motion almost ten years before the actual changes were made when several compositionists worked to exert disciplinary authority through the adoption and recommendation of a set of outcomes for the first-year writing course. Through his frustration working as a consultant to university writing programs and programs never being able to tell him what outcomes were expected of students at the end of writing courses, Edward M. White posed the following question to the WPA listserv: "Is it an impossible dream to imagine this group coming out with at least a draft set of objectives that might really work and be usable, for instance, distinguishing comp 1 from comp 2 or from 'advanced' comp? We may not have professional consensus on this, though, or even consensus that we should have consensus. How would we go about trying" (quoted in White 4)? Four years later, the WPA released the WPA Outcomes Statement for First-Year Composition ${ }^{2}$.

It is important to note that White was not frustrated "so much with the different approaches taken by different teachers - that could in fact be considered a strength—but with the differing goals and expectations they express" (White 4). White wanted to shift the conversation from what the teacher did to focus on what was expected of the students at the completion of the course. Therefore, a key component that led to the success of the WPA OS is its focus on outcomes. In recalling the development of the WPA OS, Keith

\footnotetext{
${ }^{2}$ From this point forward referred to as the WPA OS.
} 
Rhodes, Irvin Peckham, Linda S. Bergmann, and William Condon assert that with outcomes " [w]e could specify what students should do in first-year composition in terms that could work within any of the variations we knew about; and we could leave decisions about how well students should perform those outcomes where those decisions belonged - in the local context" (emphasis original 12). Kathleen Blake Yancey agrees with Rhodes et al and contends that "Outcomes provides another way of talking about and understanding curricular work... [because it allows focus to be on] what it is that we want students to know, to understand, and to do at the conclusion of a course, a program, a major" (emphasis original 21). As Rhodes et al and Yancey point out, the development of the WPA OS may have influenced the teaching of first-year writing in many ways but it has been clear from the start that the developers of this document did not seek to standardize first-year writing or exert control over the daily happening in the classroom.

Even though the majority of writing program administrators support and encourage the adoption of the WPA $O S$, not all writing program administrators endorse this statement. Two edited collections examine the uptake of and resistance to the WPA OS. The first collection, The Outcomes Book: Debate and Consensus After the WPA Outcomes Statement, published in 2005 , looks at the process of creating the WPA OS, reflects on the implementation of the document at particular locations and examines (possible) implications. The second collection, The WPA Outcomes Statement: A Decade Later, published in 2013, reflects on the ways in which the WPA OS has interacted in the field both positively and negatively. From these collections, we learn that the multiple audiences that have an interest in and participate in first-year writing were a driving consideration behind the WPA OS. Susanmarie Harrington explains that "[k]nowing that 
students, parents, deans, legislators, and teachers at other levels all had a stake in what happens in first-year composition programs led the developers to craft a statement that is plain enough to speak to those outside the discipline, yet rooted in disciplinary language enough to have status in the field" (xvi). However, the influence of the WPA OS is most likely not as far reaching as the introduction to the document indicates. The actual audience using the document is probably comprised mostly of writing program administrators seeking to do a particular type of work through the first-year writing programs that they direct. The vast majority of the people that Harrington identifies as having a stake in first-year writing programs do not take up the WPA OS in the ways in which the scholars behind the statement suggest.

While the WPA OS is quite possibility not known outside the writing program administers community, it also faces resistance at the institutional level in some locations. For example, Teresa Grettano, Rebecca Ingalls, and Tracy Ann Morse describe the resistance that they experienced when they sought to implement the WPA OS at their institution. They explain, "[w]eilding the WPA OS like a sword of valor, we entered this financially challenged institution only to learn that the ideals if the WPA OS are not universal" (45). Even though the goal of the WPA OS was "a one-page statement that captured the essence of composition programs, that pointed to the further work students could do as writers, and that helped faculty in all programs consider how to teach students to become increasingly effective writers" (Harrignton xvi), the implementation of the document experienced resistance. Grettano et al continue to argue that "[i]mplementing the WPA OS in any program is partly an ideological task. The WPS OS is a construction of knowledge from a larger body of teacher-scholars, and drawing it into 
the culture of an institution exacerbates the ideological tensions already at work in the culture of that institution" (46). The politics and institutional relationships operating at particular institutions were not always welcoming to the WPA $O S$ and faculty supporting the document had to negotiate its place in the culture.

\section{WPA OS and Precollege Credit for Writing Alternatives}

A by-product of the development and publication of the WPA OS is that the outcomes, even if not universally accepted and adopted for first-year writing, allowed precollege credit for writing alternatives, such as AP English, to more closely align programs with the outcomes endorsed by the professional field overseeing first-year writing at the postsecondary level. And, this is seen in the changes made to the AP English Language and Composition course.

Scholars have already traced the impact that the WPA OS had on influencing on the AP English Language and Composition exam ${ }^{3}$. Now referenced in the AP English Language and Composition Teacher's Guide 4 as "the rhetoric course" (1), students completing AP English Language and Composition can be expected to "construct arguments drawn from their own observations, experience, and reading...learn to synthesize as a result of their own research opportunities and...learn to analyze arguments both for their appeals - ethos, logos, pathos — and for the context in which these arguments appear" (1). Many of these changes influenced the exam for this course. As Puhr points out, the AP English Language and Composition exam also changed in 2005 to include a question in the multiple choice section that "was an attempt to align curriculum and assessment more closely with that in college composition courses, which

\footnotetext{
${ }^{3}$ For more information see Kathleen Puhr's "The Evolution of AP English Language and Composition" in College Credit for Writing in High School: The "Taking Care of" Business.

${ }^{4}$ From this point forward referred to as the Teacher's Guide.
} 
usually include study of the purposes and forms of documentation" (Evolution 75). Another change resulting from the 2002 meeting was the addition of the synthesis question in 2007. As Puhr explains the change, "[t]he newly added essay question testing this skill gives students a prompt that requires them to develop a contention about a topic, drawing on at least three of the six or seven sources provided" (Evolution 74). These changes demonstrate that AP English Language and Composition has been influenced by the legacy of the WPA $O S$ at the institutional level.

Revisions to the AP English Language and Composition course and exam can be seen to most clearly support the WPA $O S$ and a rhetorical approach to first-year composition. Many AP English Language and Composition courses are adopting a pedagogy focused on argument. This is clearly demonstrated in the Teacher's Guide. All three sample AP English Language and Composition syllabi included use Everything's An Argument as the course textbook and many of assignments ask students to make different kinds of arguments for different purposes. This focus on argumentative writing makes sense in light of the strong connection that has developed between the WPA OS and the AP English Language and Composition course.

From an outcomes standpoint, AP English Language and Composition fits into the current landscape of first-year composition as outlined by the WPA OS very well. As Puhr successfully demonstrates in "The Evolution of AP English Language and Composition" and as Jolliffe shows in the Teacher's Guide section he authors on “College Composition: Goals, Outcomes, Innovations" (4-6), AP English Language and Composition has taken great steps to align itself with the WPA OS. Every outcome for the AP English Language and Composition course can be mapped directly on to the WPA 
OS, with the most overlap occurring in the Rhetorical Knowledge and Critical Thinking, Reading and Writing sections. The only exception is the WPA OS dealing with Composing in Electronic Environment that was added in 2008. However, we must pause to question if students in AP English Language and Composition are really experiencing the same type of first-year writing that they would as first-year college students on a college campus, even though alignment is seen in the outcomes. On every level, outcomes do not necessarily result in good pedagogy. We need to look more closely at how these documents play out in practice in real classrooms and the dispositions that are being developed in students enrolled in these courses.

\section{Tensions Between Advanced Placement English and First-Year Writing}

Despite changes made by the AP program to AP English Language and

Composition, tensions exist between AP English and first-year writing. These tensions are multiple but include: concerns over pedagogy, content, location, and transfer of skills. Scholars in Rhetoric and Composition question the pedagogical practices in AP English courses because high school English course are mainly literature based and must adhere to state and district curriculum requirements. Moreover, questions also arise over the physical and institutional location of AP within high school education (Hesse). Questions of transfer also arise when considering the learning experiences of students enrolled in AP English Language and Composition because little is known about the daily practices of these courses and what is known focuses on preparing students to take the AP exam (Hansen et al; Donahue).

While multiple points of tension exist in the field of Rhetoric and Composition over granting first-year writing credit for AP English, the most visible point of tension in the scholarship concerns assessing student learning through a timed exam consisting of 
multiple-choice questions and on-demand essays. Scholars in Rhetoric and Composition dismiss the notion that any type of timed writing assessment is an appropriate assessment for a writing course (Jones; Fleitz). Jones argues that "[t]he values established for English education in the mid-1950s through the vehicle of AP examination, while not irrelevant, are nonetheless conscribed in ways incapable of accounting for advancements in theory and practice during the past fifty years" (54). Along with Jones, David Foster, Sylvia A. Holladay, and Jeffery Schwartz all raise questions about the AP exam. Writing in 1989, Foster calls for two major changes on AP English exams based on changes that occurred in the teaching of first-year writing over the past 50 years. Similarly, Holladay questions the assessment measurement of AP English courses. She claims that "[t]he AP English exams intensify problems and uncertainties in the assessment of reading, writing, and literary response" (80). While she provides a broader critique of the issue than the specific problems identified by Foster, the underlying issue of assessment remains the same. Schwartz follows Foster and Holladay and also comments on the problems of the AP exam as an assessment. However, he also argues that the AP exam is only one part of the AP experience and that "[u]ntil the test catches up with current theory and research, though, we must design curricula that meet students' needs" (56). Schwartz reminds us that the exam is only one part of the AP experience. Yet, we have little knowledge concerning other classroom practices that students enrolled in these courses experience at specific locations.

The field of Rhetoric and Composition has also periodically focused on the validity of the AP exam. In 1981, before the expansion of AP English offerings, Christopher C. Modu and Eric Wimmers found that " $[\mathrm{t}]$ he data show clearly that the AP 
candidates in secondary school performed better than the college composition students on both the multiple-choice and essay sections of the validity examination" (615). Modu and Wimmers conclude from their study of comparing scores on the AP English Language and Composition exam from high school students and students enrolled in first-year writing that the results of "[t]he study demonstrated the rigor of the new AP English examination and...its validity as a composition test" (616). However, this may also indicate that the AP English Language and Composition course focuses on test preparation. Working in 2004, and also concerned with issues of validity, Kristine Hansen, Suzanne Reeve, Jennifer Gonzalez, Richard R. Sudweeks, Gary L, Hatch, Patricia Esplin, and William S. Bradshaw point out that "there is little substantial research...focusing on the predictive validity of AP English scores for student success in college...Few studies have been performed in the last ten years, some are twenty years old or more" (31). Hansen et al continue to question the validity of AP English exams in their 2006 study of college sophomores when they "found that sophomore students that took an AP course in high school and an FYC course at BYU performed better in the two writing tasks we evaluated than did those who had only AP or only FYC" (482).

Although conversations exist in the field of Rhetoric and Composition that address the validity of the AP English Language and Composition exam, actual investigations into the practices occurring in AP English Language and Composition classrooms are missing. Moreover, little attention is given to this subject in K-12 research as the majority of research here focuses on the way in which the AP program, in general, expands possibilities and opportunities for students. Exploration into actual classroom practices, curriculum, activities, and writing tasks, such as the focus of my study, are 
important because they offer an alternative method of examining the validity of the AP English experience that examines the similarities and differences between AP English Language and Composition and first-year writing. The AP exam is just one part of the experience and investigating the classroom practices of the course can uncover important relevant information about what students in AP English Language and Composition are learning, how they are learning, and the relationship that this learning has to first-year writing.

\section{Responses from Rhetoric and Composition: Growing Attention to Precollege Credit for Writing Alternatives}

While the previous section addresses some specific tensions that exist between Rhetoric and Composition and AP English, this section focuses on the ways in which scholars in Rhetoric and Composition have responded to precollege credit for writing alternatives. In 1989, Advanced Placement English: Theory, Politics, and Pedagogy, edited by Gary A. Olson, Elizabeth Metzger, and Evelyn Ashton-Jones, presented the first in-depth look at AP English, even though the College Board's AP English course and exam had been in existence since the 1950s. This early response to precollege credit for writing sought to reach a wide audience including high school teachers of AP English, high school administrators, postsecondary administrators, and college writing instructors. This collection identifies problems with equating instruction received in AP English to instruction received in first-year writing. Specifically, David Foster argues that the AP English program was problematic because (1) the exams were thought of before the course; (2) the course focuses on preparing students to take the exam; (3) the focus is on a product, rather than a process because of the emphasis of the exam; and (4) in AP Literature and Composition, the focus is on reading texts in isolation and identifying 
literary elements. Foster proposed changing the format of the exam to address these problems.

Similarly, Karen Spear and Gretchen Flesher, in their empirical study also included in Advanced Placement English: Theory, Politics, and Pedagogy, agree that changes need to be made to the AP English exam, particularly that "AP classes might engage students in writing rather than writing the AP exam" (italics original 49). They also find that "[c]ollege students clearly value their AP experience, primarily for its enriched intellectual opportunities to read superior literature, to contemplate important ideas, to work at a faster pace, and to interact with equally capable peers" (45). Yet, they also point out that "[f]ormer AP students...needed to overcome the message of the AP course that they were finished developing as writers - a message that the decisiveness of the AP exam and subsequent waivers from college writing requirements unfortunately reinforce" (47). In short, Foster and Spear and Flesher identify problems within the conflicting values present in the AP course, exam, and first-year writing courses that student gain credit for achieving an appropriate score on an AP English exam.

More recently, College Credit for Writing in High School: The 'Taking Care of' Business, edited by Kristine Hansen and Christine R. Farris in 2010, has brought a renewed focus on the AP English course as a precollege credit for writing alternative and addresses issues such as the differences between the AP exam and first-year composition curriculum (Jones), the content of the AP Language English and Composition course and exam (Puhr), and the value of additional college-level writing instruction after AP (Whitley and Paulsen). This collection raises important issues about literacy, writing instruction, and general education requirements at both secondary and postsecondary 
levels. David A. Jolliffe summarizes these issues as follows: "First, high school and college literacy advocates need to look skeptically at two propositions...the notion that literacy is literacy is literacy, no matter what the context; and, second, the idea that once you've 'got' literacy, that you've 'got' it for life (x). In short, this collection argues that postsecondary institutions need to examine practices surrounding the granting of precollege credit for writing, including AP English credit, and consider the message that such practices send to students about learning, literacy, and postsecondary education.

Since September 2013, the issue of receiving college credit for writing completed in high school has received additional attention with the Council of Writing Program Administrators publication of its Position on Pre-College Credit for Writing and the National Council of Teachers of English publication of a policy research brief on FirstYear Writing: What Good Does It Do? Both documents address increasing concerns in the field of Rhetoric and Composition over granting first-year writing credit for work completed in high school. The Position on Pre-College Credit for Writing outlines a comparison of curriculum, student readiness, and instructors for the popular alternatives to first-year writing. While this document compares Advanced Placement, International Baccalaureate, and Concurrent Enrollment options for earning credit for first-year writing, the comments on AP are most important for this project. They assert that because of standards mandating that American Literature be taught during the junior year of high school, when most students enroll in the AP Language and Composition course, "the curriculum of an AP course is not comparable to that of the typical college FYW course. Nor is it usually a good match in terms of the practice in writing that students receive" because of the focus on preparing the students to construct timed responses for the AP 
exam (8). This position statement comes to the conclusion "that rigorous AP courses are valuable in their own right...[but] does not recommend that students take AP English tests in order to try to exchange their AP scores for FYW credit” (6-7). While this position statement acknowledges that the rigor and academic experience of taking AP courses helps prepare students to complete work at the postsecondary level, the authors contend that there is not a strong enough one-to-one correlation between AP English and first-year writing to allow AP English to replace the first-year writing experience. Along similar lines, First-Year Writing: What Good Does It Do? follows the recommendation set forth by the Council of Writing Program Administrators and recommends that "[a]lternative routes to satisfy first-year writing requirements, such as online courses, test-out options, or dual enrollment coursework, can offer students useful preparation for FYW courses. However, such instruction cannot fully replicate the experiences of FYW" (14). Again, this document praises alternatives to first-year writing programs in regard to the academic rigor they offer students but cautions against allowing these alternatives to replace traditional forms of first-year writing.

What the scholarship has yet to address concerns the ways in which AP English Language and Composition incorporates the practices, pedagogies, and theories of firstyear writing in daily instructional practices at specific locations. This research is particularly important for a number of reasons. While recent scholarship has addressed concerns over Concurrent Enrollment, International Baccalaureate, Early College, and Advanced Placement programs, in-depth investigations into intersections between classroom practices of these alternatives and traditional first-year writing courses are absent. AP English is the best location to explore these issues because it is the largest 
alternative method high school students use to fulfill first-year writing requirements while enrolled in high school, and is the option that has been around the longest ${ }^{5}$. Additionally, AP English Language and Composition is an ideal location to ground this investigation because of attempts made by the College Board to more closely align AP English Language and Composition with first-year writing through incorporating the WPA OS in the Course Description and Teacher's Guide for this course and by making changes to the exam that reflect the revised emphasis on rhetoric. In order to fill this gap, this project works in collaboration with stakeholders to investigate the ways in which AP English Language and Composition incorporates the practices, pedagogies, and theories of first-year writing at particular locations in Jefferson County, Kentucky and explores how programs, such as Advance Kentucky, are altering the purpose and function of AP by expanding access to underrepresented populations with the goal of preparing these students to enter college and experience success.

The field of Rhetoric and Composition, as well as individual first-year writing programs, would benefit from an examination of the relationship between first-year writing courses and AP English courses because students can, and often do, bypass firstyear composition by earning an appropriate score on the AP English Language and Composition exam. It is important for AP English teachers, first-year composition teachers, and college administrators deciding whether or not to grant first-year writing credit to be aware of the similarities and gaps between what is outlined in the framing documents for AP English Language and Composition and how these documents play out

\footnotetext{
5 "In 1952, a pilot program was launched introducing advanced courses in 11 initial subjects. By the 1955 56 school year, the program was underway and the College Board was invited to step in and take over administration of the program, named the College Board Advanced Placement program" (A Brief History of the Advanced Placement Program 1).
} 
in classroom practice. It is also important for these stakeholders to realize the diversity within AP English Language and Composition courses. It is also important to investigate the perceptions and attitudes that AP English Language and Composition teachers and students hold concerning the connection between the AP English Language and Composition course, first-year composition, and postsecondary writing. It is important for students enrolled in AP English Language and Composition (and their parents) to understand the ways in which this course functions as a site of first-year writing, and whether it is effective in doing so, because it fulfills the role of first-year composition for many of these students. It is also important to examine the ways in which pedagogical innovations, such as Advance Kentucky, are serving students and promoting college readiness. Finally, it is important for those concerned with college writing to understand what is happening in AP courses when we think about designing upper level writing courses, writing center pedagogy, and other programs at the postsecondary level.

Moreover, research concerning AP English in the field of Rhetoric and Composition calls for increased conversations between secondary and postsecondary teachers of writing. Hansen et al lament the lack of communication between secondary and postsecondary instructors of writing when they acknowledge the lack of knowledge concerning the type of writing that AP English students complete. They conclude, based on the lack of evidence, that "[t]hough we have little more than anecdotal data about the kind of writing these students did in their AP courses in high school, if all or most of what they did was practice writing timed essays, they will have little knowledge or skill to transfer except what they learned about writing brief timed essays" (485). While students preparing to take the AP exam most likely did practice timed writing in 
preparation for the exam, it is unfair to assume that other meaningful writing experiences were excluded from their high school AP English courses without examining classroom practices. Hansen et al recommend an "expansion and acceleration of dialogue between secondary and post-secondary institutions to determine how administrators and teachers can work together to achieve the writing outcomes necessary for students to succeed in college, and later in the workplace" (490). As James Warren points out, "by reaching out to AP programs, college writing programs can improve the alignment of high school and college writing instruction, particularly at high schools whose student population is underrepresented at postsecondary institutions" (96). More communication must take place between teachers of writing at different educational levels in order to provide more effective writing instruction to students.

\section{Frameworks for Considering Literacy, Advanced Placement English, and First- Year Writing}

While the previous section examined the growing attention that the field of Rhetoric and Composition is paying to precollege credit for writing alternatives, this section focuses on framing this investigation within prior work on literacy in Rhetoric and Composition in order to lay the foundation for this project.

\section{Ideological Model of Literacy}

This project draws on Brian Street's ideological model of literacy. Street argues for an ideological model of literacy where literacy practices are multiple and cannot be separated from context and culture. This ideological model replaces an autonomous model that "generalise[d] broadly from... a narrow, culture-specific literacy practice" (1), acknowledged a "single direction" (2) of literacy and "isolate[d] literacy" (2) from the larger social and cultural contexts. In contrast to the autonomous model, the ideological 
model is based on the belief of multiple literacies and the "culturally embedded nature of...[those] practices" (2). Moreover, under this model, literacy "practices" are taught in "context" that is impacted by "social structure" (8). The context specific focus in the ideological model allows for a shifting definition of literacy based upon the social institutions involved (8).

The ideological model is important in this investigation for three main reasons. First, the ideological model calls for the exploration of multiple literacies. This is important in the AP English Language and Composition classroom because there are several different types of literacies coming together to form the literacy experience of the course. For example, preparing for the AP exam is one type of literacy experience, but it is not the only literacy experience because students also participate in classroom literacy experiences that do not relate to preparation for the exam. Second, the ideological model pays attention to the "culturally embedded nature of...practices" (2). This is important because this project explores the literacy practices associated with different purposes and functions of AP English Language and Composition at specific locations. While all schools in this project follow the AP English Language and Composition course outcomes and curriculum, the way in which AP English Language and Composition is taken up at each particular location is influenced by the school's individual history, location, resources, teachers, and students. The third reason the ideological model is important to my project is because, under this model, literacy "practices" are taught in "context" that is impacted by "social structure" (8). This is important for my project because I am only looking at a small sampling of AP English Language and Composition 
courses and need to be aware that what these representations are reflective of the context and social skktructure of the particular locations.

\section{Literacy Sponsorship}

Deborah Brandt's notion of "literacy sponsorship" and Eli Goldblatt's concept of "deep alignment" provide ways to explore the relationship between AP English Language and Composition and first-year writing. Brandt argues that literacy sponsors "are any agents, local or distant, concrete or abstract, who enable, support, teach, model, as well as recruit, regulate, suppress, or withhold literacy — and gain advantage by it in some way" (166). As her definition suggests, the literacy practices of certain groups, such as AP English students, are influenced by the ways in which sponsoring agencies and institutions frame and promote literacy. For example, in considering the literacy sponsors of AP English Language and Composition, multiple literacy sponsors can be identified: the College Board, the local school district, programs such as Advance Kentucky, the individual school, the teacher, and parents. All of these sponsors have certain interests in sponsoring literacy in specific ways and their enactment of literacy sponsorship is shaped in response to these interests. Literacy sponsors powerfully impact the literacy that students in AP English Language and Composition have access to because they "set the terms for access to literacy and wield powerful incentives for compliance and loyalty" (Brandt 166-167).

Brandt's explanation of sponsors applies in thinking about the multiple literacy sponsors of AP English Language and Composition. She asserts that "[s]ponsors... are powerful figures who bankroll events or smooth the way for initiates. Usually richer, more knowledgeable, and more entrenched than the sponsored, sponsors nevertheless enter a reciprocal relationship with those they underwrite. They lend their resources or 
credibility to the sponsored but also stand to gain benefits from their success" (167). The sponsors of AP English Language and Composition, most specifically the College Board, stands to gain economically through the sponsored buying into the program and agreeing to purchase access to the AP English Language and Composition exam. Moreover, local districts and schools also stand to gain financially and in reputation by effectively sponsoring students in the AP English experience. Advance Kentucky also seeks to gain as students experience success and teachers and schools within this system seek to gain financial resources. While the literacy sponsors of AP English Language and Composition seek to gain, the sponsored, in this case the students, also seek to gain from the relationship. Students enrolled in AP English Language and Composition seek to gain prestige in the increasingly competitive college application process, higher class rankings (since AP courses are typically weighted more heavily), the potential to earn college credit while still enrolled in high school, and be more prepared for postsecondary writing experiences. In short, students are invested in the sponsored relationship because the relationship provides them with capital for future college success.

AP English Language and Composition provides students with access to a valuable good—nationally recognized rigorous coursework and potential college creditas they seek to market themselves competitively in the college application process. As Brandt points out, "[a] focus on sponsorship can force a more explicit and substantive link between literacy learning and systems of opportunity and access" (169). Yet, this access is not equal, as demonstrated by the disproportional number of students having access to quality AP English Language and Composition courses and the recent local push to increase minority enrollments in AP courses. However, initiatives do exist to 
assist students not traditionally served by the AP program. One of the goals of Advance Kentucky is to provide opportunities to students that have traditionally been shut out of the benefits offered by the AP program and its rigorous curriculum.

Goldblatt expands on Brandt's notion of literacy sponsorship by focusing on "associat[ing] sponsorship with institutional realities" (113). However, he points out that "neither...[him or Brandt] has said very much about the nature of the institution determining how teachers, as local agents, administer literacy sponsorship under the specific demands of time and place" (113). He addresses this gap in Because We Live Here: Sponsoring Literacy Beyond the College Curriculum and argues that differences in local practice can be interpreted through the ways in which different instructors at different schools "operate under very different sponsoring notions of literacy due to their institutional affiliations, their relationship to market forces, and the history of schooling students bring to the classroom" (114). The notions of sponsorship outlined by Brandt and Goldblatt present productive frames for examining the ways in which sponsorship is functioning at particular locations in relation to AP English Language and Composition.

I am arguing that AP English Language and Composition is sponsoring literacy in ways similar to first-year writing, but we need to understand the differences that exist in this sponsorship based on location, history, and resources available. I am also arguing that secondary and postsecondary institutions need to practice what Goldblatt terms "deep alignment" (96). By this he means "a connection between institutions that goes beyond articulation agreements and the automatic acceptance of course equivalencies" (96). Before the determination can be made if AP English Language and Composition is providing the same type of literacy experience that a first-year writing course would 
provide, the practices of particular locations must be examined to see the ways in which the foundational documents, such as outcomes, are enacted in practice. Moreover, given that Advanced Kentucky is expanding the purpose of AP to include preparing students for college but not necessarily focusing on earning precollege credit, postsecondary institutions should be aware of the ways in which the AP course is being used in secondary institutions to prepare students to enter higher education.

In addition to conceptions of sponsorship and deep alignment, AP English Language and Composition and first-year writing both operate in specific institutional contexts and these contexts are influenced by institutional power dynamics. I understand academic literacy and college writing to be impacted by the local histories and structures of which they are part. I also understand academic literacy and college writing to be impacting these histories and structures. Work by David Barton and Mary Hamilton allow me to focus on the situated and social nature of the practices that occur in AP English Language and Composition classrooms that are part of my project. Moreover, the literacies that will be fostered in the AP English Language and Composition spaces will be "positioned in relation to the social institutions and power relations which sustain them" (1). It is important to examine the ways in which the physical and institutional location of AP English Language and Composition in high schools and within secondary school curriculum and ideologies influences the way writing is taught in AP English Language and Composition. Not only are institutional forces at play, students' literacies extend beyond the walls of the AP English Language and Composition classroom and students bring their histories and experiences with them into the classroom. The same is true of AP English Language and Composition teachers. Barton and Hamilton help me 
to position the literacies occurring in AP English Language and Composition classes in relation to the larger structures impacting specific locations.

While there has not been scholarship in the field of Rhetoric and Composition that addresses how the literacy practices of AP English Language and Composition function in terms of first-year writing, the existing scholarship does call for increased conversation between secondary and postsecondary teachers of writing. Writing program administrators and instructors need an awareness of where students are coming from and where they are going in order to build on the literacies students already have and to help cultivate the literacies that they may need in the future. This means that postsecondary teachers of writing have an obligation to understand the writing experiences occurring in high school and the ways in which these experiences sponsor literacy, and this means a deeper understanding of what it means to grant first-year writing credit for AP English Language and Composition.

The best place to investigate the ways that AP English Language and Composition functions as a site of first-year writing and open conversations between secondary and postsecondary teachers is in the classroom through collaboration with the stakeholders involved. This type of investigation fits with a longstanding tradition in the field of Rhetoric and Composition of studying what happens in the classroom. Elizabeth Chiseri-Strater presents a way of looking at how students make sense of academic literacy practices and negotiate past and current literacies to operate successfully in new situations through studying what happens in the classroom and talking about her observations with the stakeholders in Academic Literacies. This is important because all students enrolled in AP English Language and Composition bring with them many years 
of literacy experiences, including, for many, prior experience with/in other AP courses. In addition to these school literacies that the students bring into this space, they bring outof-school literacies that they are remaking and using to navigate the AP English Language course. It is important to this project to consider how students negotiate and use their multiple literacies in the environment of the AP English Language and Composition course.

\section{Actor-Network Theory as Heuristic for Examining the Connections Between AP English Language and Composition and First-Year Writing}

The previous section examined the ways in which prior work in literacy studies

provides a foundation for this project. This section focuses on the benefits and limitations of using actor-network theory as a heuristic to examine the ways in which AP English Language and Composition operates as a site of precollege credit for writing, as preparation for college bearing coursework at the completion of secondary education at particular locations, and as preparation for the AP English Language and Composition exam.

Recently, studies in education have been using actor-network theory as a heuristic to examine practices, policies, and networks. In Actor-Network Theory in Education, Tara Fenwick and Richard Edwards explain that "Actor-network theory examines the associations of human and non-human entities in the performance of the social, the economic, the natural, the educational, etc" (3). In these examinations, "[t]he objective is to understand precisely how these things come together...to form associations that produce agency and other effects" (italics original 3). Actor-network theory is important for this investigation into the practices of AP English Language and Composition because it allows for "non-human entities" to be examined in order to see the ways in which these 
objects function in networks at particular locations and in relation to other "human and non-human entities." Of particular importance here is the ways in which the AP English Language and Composition foundational framing documents (outcomes, course description, prep material, etc.) function in certain locations and how these foundational framing documents relate to other "human and non-human entities" in the network of AP English.

Additionally, when talking about AP English Language and Composition teachers, it is important to acknowledge that "[a] human being is not an autonomous clump of emotions, intentions, memories, and acquired skills in one isolated sack of skin, because these elements are shaped and inscribed by non-human things" (Fenwick \& Edwards 35-36). The individual experiences that AP English Language and Composition teachers bring with them into the classroom influence their perspectives and choices within the classroom. While all AP English Language and Composition teachers complete the required training sponsored by the College Board and have their course syllabi approved through the audit process, the actual enactment of the curriculum is influenced by individual experiences and institutional support. Actor-network theory allows a way to investigate the individual choices made by "human entities" within the larger network of AP English Language and Composition and within the smaller local network of AP English Language and Composition at the district and school level.

Furthermore, the material conditions under which AP English Language and Composition operates differ greatly from location to location. The materials available (or lack of materials available) affect the ways in which AP English Language and Composition is enacted. The "non-human entities" that participate in the AP English 
Language and Composition network work to provide particular experiences for students. Technology, books, examination preparation material, and afterschool resources operate differently based on location.

AP English Language and Composition can be considered to occupy several places in several different networks. For example, the largest and seemingly most stable network to which AP English Language and Composition belongs is that of the College Board. However, as the course moves into different networks, its perceived stability waivers. At the state and district level, AP interacts and intersects with local curricular requirements at some locations. Furthermore, perhaps the variable presenting the most instability is at the micro-level at the local and individual uptake of the AP English Language and Composition course at particular schools. The way in which AP English Language and Composition functions at individual schools, while bounded by the AP English Language and Composition outcomes statement, is greatly influenced by other nodes occupying the local network, such as teacher experience and investment, available texts, and technology. Moreover, AP English Language and Composition has also become intertwined with parts of the network associated with college readiness through programs, such as Advance Kentucky.

Work involving actor-network theory and the ways in which standardized curriculum is enacted at multiple locations informs what this project does with AP English Language and Composition. Fenwick and Edwards maintain that "ANT-informed studies of curriculum accept that such a degree of control is temporary stabilization at best" (57). Therefore, while the AP program maintains continuity through the approved AP English Language and Composition outcomes statement, Advanced Placement 
Summer Institutes, syllabi audits, and the examination, the reality is that control over the enactment and daily practice of the course are non-existent. The control and stability are constrained by the framing documents produced, supported, and approved by the College Board. Fenwick and Edwards continue to suggest that "It is in the observations of the enacted curriculum that we often witness tensions between what is intended, what is aspired to and what is achieved" (57). Thus, the individual uptake and enactment becomes important to the consideration of the daily practices of AP English Language and Composition.

While using actor-network theory as a lens to examine the practices of AP English Language and Composition is productive, it also brings limitations. Actornetwork theorists caution against what is termed the "black box." Fenwick and Edwards argue that the outcomes may "appear immutable and inevitable, while concealing all the negotiation that brought it into existence" (11). For example, the College Board did not simply alter AP English offerings without negotiating changes through considering the landscape and history of the first-year composition course. Furthermore, the most recent changes to the AP English Language and Composition course and exam did not occur solely because of the production and adoption of the WPA $O S$, even though that move greatly influenced the change. Additionally, AP is also responding to changes in postsecondary institutions and the assignment of credit for AP courses. In short, when using actor-network theory, negotiations between parts of the network, between networks, and boundary objects must be considered in light of the forces that work for and against their shaping. 
This chapter has contextualized this project within the historical landscape of the development of first-year writing courses and locates the rise of AP English courses within this history. After exploring the histories and intersections between first-year writing and AP, this chapter moved to examining the ways in which the College Board's AP English course offerings responded to changes in first-year composition by evolving the AP English Language and Composition course. The tensions between AP English and first-year composition are then explored to highlight the complexity of the relationship between the two programs. The chapter then looked at recent developments in Rhetoric and Composition that pay growing attention to precollege credit for writing alternatives, which includes AP English courses. This chapter concluded with an investigation of how literacy studies and actor-network theory provides a heuristic to examine the connections between AP English Language and Composition, first-year writing, and college readiness.

\section{Chapter Summaries \\ Chapter Two: Methods and Methodology}

Chapter two describes the research methods used to conduct the study that is reported in this dissertation. Details concerning data collection methods and descriptions of participating schools, teachers, and students are included. The methodology underlying this project is also discussed in this chapter. This chapter concludes by addressing ethical considerations and limitations.

\section{Chapter Three: The Framework for Success in Postsecondary Writing, AP English}

\section{Language and Composition and College Readiness}

While typical conversations about AP English center on the course as an option for precollege credit for writing, chapter three argues that AP English Language and 
Composition is designed to provide a learning environment that promotes college readiness by encouraging the development of dispositions that have been linked with success. Thus, this chapter focuses on the ways in which the policies associated with AP English Language and Composition promote learning environments that focus on the development of dispositions identified in the Framework for Success in Postsecondary Writing.

\section{Chapter Four: Cultivating Dispositions through Literacy Sponsorship: AP English}

\section{Language and Composition}

Chapter four continues the investigation begun in chapter three. However, the focus of this chapter shifts to practices occurring in multiple AP English Language and Composition classrooms throughout Jefferson County, Kentucky. Specifically, this chapter explores the types of literacy experiences occurring in six classrooms and the ways in which these experiences relate to dispositions identified in the Framework for Success in Postsecondary Writing.

Chapter Five: Exceptional Constructions of AP English Language and Composition: AP English Language and Composition as First-Year Writing

Chapter five provides a case study of AP English Language and Composition at Violet Fields High School, a highly ranked, affluent school with a privileged student population. This examination finds that the AP English Language and Composition course at this location is effectively serving as a site of first-year writing, which is important as many of the students intend for this class to fulfill their first-year writing requirement. However, this chapter points out that the rigor, challenge, and complexity in 
this AP English Language and Composition course is unique to this particular location and would be difficult to replicate at another school with a different student population.

\section{Chapter Six: Traditional Constructions of AP English Language and Composition:}

Chapter six provides a case study of AP English Language and Composition at Blue Meadows High School. This examination is representative of the ways in which AP English Language and Composition functions at many schools across the district. This exploration finds that, while the AP English Language and Composition course is challenging, meets the outcomes outlined by the course by the College Board, and covers a variety of material, the writing instruction, the type of writing assignments included and the frequency at which students are asked to compose are not sufficient for this course to successfully function as a site of first-year writing instruction. This is problematic because many students, and the teacher, view this course as a precollege credit for writing alternative. Therefore, students exiting this course with a high enough score on the AP English Language and Composition exam have the potential to bypass first-year writing and without experiencing foundational writing instruction or composed assignments that are comparable to those completed in first-year writing courses.

\section{Chapter Seven: Innovative Constructions of AP English Language and Composition:}

\section{Precollege Credit for Writing and preparation for College Readiness}

Chapter seven provides a case study of AP English Language and Composition course at Red River High School. This chapter examines how Red River High School's participation with Advance Kentucky facilitates an open enrollment policy for AP courses and addresses the influence that this relationship has on the AP English Language and Composition course and writing instruction. Because of the dual nature of the student 
population enrolled in AP English Language and Composition - those viewing it as a site of precollege credit for writing and those seeking to gain preparation so as to meet college readiness benchmarks so that they are able to enroll in first-year writing when they enter their chosen postsecondary institution - the course is functioning as both a site of first-year college writing and as a site of college preparation.

\section{Conclusion}

The conclusion addresses implications of the findings of this project for secondary and postsecondary teachers of writing by drawing attention to the variety of course experiences found in AP English Language and Composition and drawing attention to the multiple purposes that AP English Language and Composition serves. It also discusses implications for policy and pedagogy in AP English Language and Composition. The conclusion ends by examining limitations of this project and calling for future research. 


\section{CHAPTER 2: METHODS AND METHODOLOGY}

\section{Introduction and Project Overview}

Recent research in Composition Studies focuses on the diversity present within the methods and methodologies in the field. Lee Nickoson and Mary P. Sheridan capture this diversity well in Writing Studies Research in Practice by drawing attention to important methodological and ethical considerations. Importantly, they point out that "[a]lthough readers may find the distinction between methods and methodology to be hazy, such slippage exposes the complex ways researchers navigate this intertwining of practice and theory" (italics original 2). Thus, in this chapter I explain not only what I did to collect data for this project but why I made these choices throughout. As Nickoson and Sheridan point out, distinguishing between my methods and methodology is difficult and the two are interwoven in the description that follows.

My project explores the multi-nature of AP English Language and Composition as it functions in Kentucky as a site of first-year writing for some students, as a site of college preparation through innovative programming for others, and as a site of test preparation. Many investigations of AP English focus on the alignment of learning outcomes between AP English Language and Composition ${ }^{6}$ and first-year college writing or the granting of college credit for certain scores on the AP English Language and

\footnotetext{
${ }^{6}$ For more information see: Puhr, Kathleen M. "The Evolution of AP English Language and Composition." College Credit for Writing in High School: The 'Taking' Care of Business. Urbana, IL: National Council of Teachers of English, 2010. 68-85. Print.
} 
Composition exam ${ }^{7}$. However, this project expands the conversation by examining how the course operates as a hidden site of first-year writing, as it functions simultaneously as a site of precollege credit for writing, a way to prepare students to enter postsecondary education ready to enroll in credit bearing courses, and as a site of test preparation. It also questions the ways in which AP English Language and Composition is enacted differently at different locations because of the history associated with individual schools, resources available, experiences brought into the classroom by individual teachers, and the background and goals of students. This project incorporates a variety of qualitative research methods. Including:

- observations from AP English Language and Composition courses

- individual interviews with AP English Language and Composition teachers from across Jefferson County Public Schools

- textual analysis of data supplied by current AP English Language and Composition teachers

- interviews and surveys, with students enrolled in the AP English Language and Composition courses being observed

- textual analysis of data published by the College Board

Although the study size is small and generalizing from case studies does present limitations, this study highlights the differences and similarities between AP English Language and Composition and first-year writing and explores the multiple functions that the course serves. This study was granted IRB approval at the University of Louisville

\footnotetext{
${ }^{7}$ For more information see: Hansen, Kristine, Suzanne Reeve, Jennifer Gonzalez, Richard R. Sudweeks, Gary L. Hatch, Patricia Esplin and William S. Bradshaw. "Are Advanced Placement English and First-Year College Composition Equivalent? A Comparison of Outcomes in the Writing of Three Groups of Sophomore College Students." Research in the Teaching of English, 40.4 (2006): 461-501. Print. JSTOR.
} 
and approval by the Jefferson County Schools Office of Research. Pseudonyms are used for all school names, teacher names, and student names. The following question guides this project: How does AP English Language and Composition prepare students for postsecondary writing experiences?

\section{Research Questions}

- How does the AP English Language and Composition course encourage literacy that promotes preparation and readiness for postsecondary education? What connections exist between the types of sponsorship occurring and the Framework for Success in Postsecondary Writing?

- What kinds of writing pedagogies are practiced in AP English Language and Composition at the particular locations under study? In what ways do these pedagogies and theories work to prepare students for postsecondary writing experiences? In what ways do these practices use available resources?

- In what ways are pedagogical innovations changing how AP English Language and Composition operates?

\section{Participants}

\section{Study Location}

This project took place in the state of Kentucky. Kentucky was the first state to formally commit to participating in the Common Core State Standards in 2009, was active in making changes in response to the No Child Left behind Act in the 2000s, and gained national attention in the 1990s with the Kentucky Educational Reform Act (KERA). The 2014 Kentucky Performance Rating for Educational Progress (K-Prep) test scores indicate that $62.3 \%$ of students in the state are college and career ready, up from 
$54.1 \%$ in 2013 and exceeding the goal for growth ${ }^{8}$. The state is taking active measures to increase the percentage of students who graduate from Kentucky schools ready for college and career. These measures include programs such as Advance Kentucky, Complete College America, and other initiatives to increase students' preparation for entry in postsecondary education and the workforce.

According to the 2013-2014 District Report Card ${ }^{9}$, Jefferson County Public Schools served 95, 794 students during the 2013-2014 school year, making it the largest district in the state. The demographic population by race for this period breaks down as follows: 49.2\% white, 36.1\% African American, 8.2\% Hispanic, 3.4\% Asian, 0.1\% American Indian or Alaska Native, $0.1 \%$ native Hawaiian or other Pacific Islander, and $3 \%$ identified as two or more races. The ratio of male to female students for this period was almost equal with $50.8 \%$ male and $49.2 \%$ female. Jefferson County Public Schools has a free lunch rate at $57.3 \%$ and a reduced lunch rate at $5.7 \% .72 \%$ of students exiting Jefferson County Public high schools indicated that they would be attending college. There are ninety elementary schools, twenty-seven middle schools, twenty-two high schools, and twenty-nine special schools in the district ${ }^{10}$. Students enrolling in high school are assigned a resides school based upon their home address but may apply to Five Star Programs, Magnet Schools, Magnet Programs, and other high schools with Open Enrollment.

\section{Schools and Teachers}

Out of twenty-two high schools listed on the Jefferson County Public Schools webpage, contact information for either the English Department Chair or AP English

\footnotetext{
${ }^{8}$ Information obtained from the State Report Card. Update 9/27/2014.

${ }^{9}$ Updated 8/11/2014.

${ }^{10}$ Information obtained from the JCPS website. Accessed 10/12/2014.
} 
Language and Composition teacher was located for sixteen schools. An IRB approved email soliciting participation for this study was sent to these sixteen schools. Eight responses were returned. Two of the schools did not offer AP English Language and Composition during the 2013-2014 school year. The other six responses either indicated interest in participating or forwarded the participation invitation to the appropriate teacher. From these six contacts, seven teachers from five different schools agreed to be interviewed. Five interviews took place. Two interviews were abandoned after numerous attempts to schedule failed. After the initial interview with the five teachers, I inquired about conducting observations in each teacher's AP English Language and Composition class. Of these five, two teachers at different locations immediately agreed to allow me to come back weekly for observations. Two other locations extended offers but I had to decline because their schools operated on a rotating block schedule that interfered with my own work and teaching schedule. One location felt that it would be very difficult to get parental consent documents returned and offered her classroom as a last resort site. In the following section, I describe the teachers who agreed to be interviewed and the schools at which they teach ${ }^{11}$.

\section{William-Blue Meadows High School}

William teaches AP English Language and Composition at Blue Meadows High School in Jefferson County, Kentucky. William has been teaching AP English Language and Composition for many years and taught two sections during the 2013-2014 school year. He also serves as the English Department Chair. He participated in the Advanced Placement Summer Institute training before he began teaching the course. Blue Meadows High School is a magnet school that students must apply to in order to attend. It offers

${ }^{11}$ See the appendix for a chart comparing the schools involved in this project. 
seventeen AP courses. In the 2013-2014 school year, 1,724 students were enrolled. The demographic population by race is as follows: $62.5 \%$ white, $32.6 \%$ African American, 2.2\% Hispanic, $0.1 \%$ American Native or Alaska Native, $0 \%$ Native Hawaiian or Other Pacific Islander, and $1 \%$ identifying as two or more races. The school is labeled as a "School of Distinction" and is classified as "Distinguished/Progressing" with an accountability score of 86.4 . The school spends an average of $\$ 6,524$ per student. $23.3 \%$ of the students were receiving free lunch and $7.5 \%$ of students were receiving lunch at a reduced rate. The average student to teacher ratio is 21:1. The teachers at Blue Meadows High School have the following professional qualifications: 4.5\% Bachelor's, 51.1\% Master's, 35.2\% Rank 1, 2.3\% Specialist, and 2.3\% Doctorate.

\section{Sophia-Green Gables High School}

Sophia teaches AP English Language and Composition at Green Gables High School in Jefferson County, Kentucky. Sophia has been teaching AP English Language and Composition for three years. She attended the Advanced Placement Summer Institute at Western Kentucky University the summer before she began teaching the course. She is the Regional Coordinator for Advance Kentucky. Green Gables High School hosts a Culinary Arts Program and Professional Career Theme Programs. It also participates in Advance Kentucky. It is one of the lowest performing schools in the district. During the 2013-2014 school year, 709 students were enrolled. The racial breakdown for the school is: $37.5 \%$ white, $49.1 \%$ African American, 9.3\% Hispanic, 2.4\% Asian, and $1.7 \%$ identify as two or more races. The school is labeled as a "Priority School" and classified as "Needs Improvement/Progressing" with an accountability score of 65.1. The school spends an average of $\$ 13,091$ per student. The free lunch rate is $72.9 \%$ and the reduced lunch rate is $4.2 \%$. The average student to teacher ratio is $13: 1$. The teachers at Green 
Gables High School have the following professional qualifications: 7.6\% Bachelor's, 53\% Master's, 30.3\% Rank 1, 1.5\% Specialist, and 0\% Doctorate.

\section{Henry-Orange Tree High School}

Henry teaches AP English Language and Composition at Orange Tree High

School in Jefferson County, Kentucky. He teaches two sections of the course. He has been teaching for over twenty years and has also taught first-year composition at the University of Louisville while completing his Master's in English. He also attended the Advanced Placement Summer Institute the summer before he began teaching the course. Henry was responsible for establishing AP English Language and Composition at Orange Tree High School. Orange Tree High School is a magnet school that has programs in medicine, law, computer technology, and business. During the 2013-2014 school year, 1,088 students were enrolled at Orange Tree High School. The demographics of the student population during this time included: $7.8 \%$ white, $80.9 \%$ African American, $6.6 \%$ Hispanic, 3.6\% Asian, and $1.1 \%$ identifying as two or more races. The school has been labeled as a "Focus School" and classified as "Needs Improvement/Progressing" with an accountability score of 68.7. Orange Tree High School spends an average of $\$ 9,776$ per student. $74.2 \%$ of the students received free lunch and $9.6 \%$ of the students received their lunch at a reduced rate during the 2013-2014 school year. The student to teacher ratio is 15:1. Teachers at Orange Tree High School have the following professional qualifications: 9.4\% Bachelor's, 37.6\% Master's, 38.8\% Rank 1, 1.2\% Specialist, and $3.5 \%$ Doctorate.

\section{Owen-Red River High School}

Owen teaches AP English Language and Composition at Red River High School in Jefferson County, Kentucky. He teaches three sections of the course. He has been 
teaching for ten years, after spending nine years in the United States Navy as a commissioned officer. He received his Master's in English from the University of Louisville in 2004 and completed coursework for a Ph.D. in Humanities in 2011. Red River High School participates in the Five Star Program and is an Advance Kentucky participant. It enrolled 1,389 students during the 2013-2014 school year. The racial demographic breakdown is: $48.2 \%$ white, $37.9 \%$ African American, $7.5 \%$ Hispanic, $4.5 \%$ Asian, $0.1 \%$ American Indian or Alaska Native, and 1.9\% identifying as two or more races. The school is labeled a "Priority School" and classified as "Proficient/Progressing" with an accountability score of 71.4 . Red River spends an average of $\$ 8,268$ per student. The free lunch rate is $55.8 \%$ and the reduced lunch rate is $8.1 \%$. The student to teacher ratio is 17:1. The teachers at Red River High School have the following professional qualifications: 15.5\% Bachelor's, 40.2\% Master's, 26.8\% Rank 1, 1.0\% Specialist, and $1.0 \%$ Doctorate.

\section{Stella_Violet Fields High School}

Stella teaches at Violet Fields High School in Jefferson County, Kentucky. She teaches two sections of the course. She has been teaching AP English Language and Composition for eight years. She attended the Advanced Placement Summer Institute training the summer before she began teaching the course. Violet Fields High School is a magnet school that is ranked top in the state. It offers 27 AP courses, the most of any high school in Kentucky, and has the highest ACT average of any school in the state. During the 2013-2014 school year, 1,860 students were enrolled. The racial demographics of the student population include: $67.1 \%$ white, $15.9 \%$ African American, $2.5 \%$ Hispanic, 12.9\% Asian, $0.1 \%$ American Indian or Alaska Native, $0.3 \%$ Native Hawaiian or other Pacific Islander, and $1.2 \%$ identifying as two or more races. Violet Fields High School is 
labeled as a "School of Distinction" and classified as "Distinguished /Progressing" with an accountability score of 91.8 . The school spends an average of $\$ 7,845$ per student. The free lunch rate for 2013-2014 was 16.8\% and 3.8\% percent received lunch at a reduced price. The student to teacher ratio is 20:1. The teachers at Violet Fields High School hold the following professional qualifications: 7.3\% Bachelor's, 36.6\% Master's, 46.3\% Rank 1, and $2.4 \%$ Doctorate.

\section{Students}

Student participants were solicited from the schools-Blue Meadows High School and Red River High School—where teachers agreed to allow me observe. Informed consent was received from participating students over the age of eighteen. Parental consent and student assent were received from participating students under the age of eighteen. I received consent from sixty-eight total students. From this, fifty-nine completed surveys and thirty-two were interviewed.

The students at Blue Meadows High School are traditional AP students who have achieved certain scores on standardized assessments, been in the advanced track, and received teacher recommendation for the course. They are all in the eleventh grade and plan to enroll in AP English Literature and Composition or dual credit English offered through the University of Louisville during their senior year. The majority also expressed that they were hoping to gain some form of college credit from taking the course and bypass part of the first-year writing requirement when they enrolled in their postsecondary institution. During my first observation at Blue Meadows High School, participation was solicited from the students. William explained to the students that I would be observing their class and that they would have the opportunity to talk with me about my research at the end of the school year. He also explained to them that, because 
they were not yet eighteen, we needed their parents to consent to their participation in this study. I explained the consent form to the students and attached to the consent form a letter addressed to parents explaining my project. Many students returned their consent forms the next class day and William collected them. When I returned the next week, I spoke with each student who had returned a parental consent form and explained the assent form. This occurred during the middle of March. Students continued to bring in parental consent forms for several weeks and I continued to explain assent forms. William and I agreed that I would observe on Tuesday afternoons until the AP English Language and Composition exam. In late May, after the students had taken all of their AP exams and end of course exams, I returned to distribute surveys and interview students. More information about this process will be included in the section below when I discuss data collection for interviews.

Red River High School practices open enrollment for AP courses because of their participation in Advance Kentucky. Therefore, the students at this location span a range in terms of grade level, scores on standardized assessments, English Language status, prior high school English course, and plans for their next English course. At Red River High School, Owen had told the students that I would be coming to talk with him about a project I was completing on AP English. I observed the first class immediately after my initial interview with Owen. During this time, I explained to the students who I was and what I was doing at their school. I also explained and distributed consent forms. The majority of the students were not yet eighteen so they had to take the forms home for their parents to sign. However, a handful of students in this class were seniors and had turned eighteen. These students returned the consent forms immediately. Similar to Blue 
Meadows High School, many students returned the consent forms the next day and Owen collected them for me. Again, I attached a letter to parents that explained my project. When I returned for my second observation, I explained assent forms. However, Owen soon realized, when students began asking me questions and the students in the class did not match up to the roster he had given me the week before, that Red River High School had changed trimesters and shuffled students based on schedule changes since my first observation a week earlier. Thus, I explained my project and the consent forms again to new students. Owen and I decided that, even though I would be observing during fourth period, we would open the survey and interview to all three of his classes because of the shuffle that had taken place. I was invited to show up anytime to observe and my weekly observations soon grew to twice weekly when my schedule permitted. The day after the AP English Language and Composition exam, I returned for the first set of student interviews. I also returned the following week to accommodate the large number of students that volunteered to be interviewed. More details about student interviews can be found below when I discuss student interviews.

\section{Methods and Methodology}

This project is ethnographically informed. Judith Green and David Bloome describe the differences between "doing ethnography" (italics original 183), "adopting an ethnographic perspective" (italics original 183), and "using ethnographic tools" (italics original 183). They assert that "doing ethnography involves the framing, conceptualizing, conducting, interpreting, writing and reporting associated with a broad, in-depth, and long-term study of a social or cultural group, meeting the criteria for doing ethnography as framed within a discipline or field" (italics original 183). While embracing "an ethnographic perspective...mean[s] that it is possible to take a more focused approach 
(i.e., do less than a comprehensive ethnography) to study particular aspects of everyday life and cultural practices of a social group. Central to the ethnographic perspective is the use of theories of culture and inquiry practices derived from anthropology or sociology to guide the research" (italics original 183). Finally, "using ethnographic tools, refers to the use of methods and techniques usually associated with fieldwork. These methods may or may not be guided by cultural theories or questions about the social life of group members" (italics original 183). This project fits into this third category of "using ethnographic tools" because I adopt the data collection methods of observations and interviews to examine the practices of AP English Language and Composition. Ethnographic research and using ethnographic tools have a long history in the field of Rhetoric and Composition and literacy studies.

Early ethnographies focus on literacy in home, community, and school contexts. These early studies borrowed heavily from anthropology and education. Shirley Brice Heath's Ways with Words is one of the earliest ethnographies to focus on literacy practices is a key text in the history of using ethnographic research methods to investigate literacy. In her extended study of the communities of Roadville and Trackton, Heath traces home and community literacy practices of these two communities by following children from these communities into school where she explores the ways in which home and community literacy practices influenced the experiences the children had in school. Heath's work shows researchers the benefits of ethnographic research and thick description that could be accomplished when the researcher spent extended amounts of time living and working in the community being studied. Similarly, Ralph Cintron follows in the ethnographic footsteps of Heath in Angelstown - his ethnographic study of 
the literacy practices of a Latino community outside of Chicago. Those of us interested in literacy are particularly intrigued by Cintron's examination of Valerio and the learning disabled label placed upon him by the school. Similar to Heath's study, we see Valerio's literacy both in and out of school. In both of these ethnographies, we see that the researchers are able to take an emic perspective because they take the time to develop relationships with their participants through participating as a member of the community under study.

While Heath and Cintron both perform ethnographies that follow participants inside and outside of classroom experiences, ethnographic work in the field of Rhetoric and Composition has also had a powerful influence in examining literacy within educational contexts. Elizabeth Chiseri-Strater's Academic Literacies: The Public and Private Discourse of University Students is one such study. In this ethnography ChiseriStrater follows Anna and Nick through selected university courses to examine the ways in which they negotiate academic literacy expectations. She finds that the university did not adequately support Anna or Nick causing their performance to suffer. In fact, she claims that Anna and Nick can be considered literate in spite of, not because of, the literacy support given to them in these academic circumstances. They both had to rely on previous literacy experiences in an attempt to negotiate the academic literacy expectations of their courses.

Similar to Chiseri-Strater, Glynda Hull, Mike Rose, Kay Losey Fraser, and Marisa Casrellano present results from an educational ethnographic study that they performed in a college writing classroom where June, the teacher, dismissed comments made by Maria, the student, and labeled her as having trouble connecting ideas because 
she did not follow the IRE sequence that structured many traditional educational classrooms, such as June's. Similar to Hull et al, Pamela Hartman also performs ethnographic work in an educational setting when she explores the influence of class and gender on a group of working-class girls in a high school English class. She finds that the teens in her study valued the "good girl" and "good student" labels and worked to fit into these labels. Through the use of classroom ethnographies, these researchers demonstrate the ways in which extended participant-observation can render unfamiliar educational situations familiar. Moreover, these classroom ethnographies usually present some type of knowledge or recommendation for practice that other scholars can take and apply. For example, Chiseri-Strater suggests that professors model reading and writing and work to apprentice their students; Hull et al suggest we look away from deficit models when our students struggle and consider other possible interpretations; Hartman suggests we pay attention to the ways in which class and gender influence students' expectations.

Although I acknowledge that the anthropological tradition would not classify this project as ethnography, this project follows the ethnographic tradition found in Rhetoric and Composition by adopting ethnographic tools. Over twelve weeks, I spent multiple days a week observing in three different AP English Language and Composition classes located at two different schools. While I do not classify this project as a traditional ethnography because I entered these communities after they had been formed, was able to spend only a few hours a week with each community, and it is questionable if a classroom can be a site of a true ethnography because students are grouped by institutional forces instead of self-selecting to be part of individual classroom communities, I did use the ethnographic methods of observation to collect data about the 
classroom practices and learning environments at these locations. Moreover, I also adopted the ethnographic tool of interviewing individuals involved with AP English Language and Composition at each location. Using these methods, I completed over twenty hours of classroom observations, and thirty-six interviews over twelve weeks.

I gathered data from multiple sources: classroom observations, interviews with teachers, surveys and interviews with students, and textual materials. Multiple data sources were important for this project because they allowed multiple angles of AP English Language and Composition to be investigated from multiple perspectives. For example, the textual data obtained from the College Board allowed the boundary objects for the course to be examined in the form that is officially sanctioned by its creators and promoters. The textual documents provided by the participating teachers allowed for an investigation of the official practices to be extended to the ways in which individual teachers at local schools enacted the course. The textual documents created by teachers also allowed interview conversations with teachers to look at the ways in which they were interpreting the materials provided by the College Board. This allowed for additional information to be gained about the classroom practices that typically occur in their AP English Language and Composition courses. Additionally, the surveys that student participants completed allowed for an overview of student attitudes and beliefs concerning AP English Language and Composition and first-year composition to be explored and provided a foundation for student interviews where students were asked to further discuss the themes addressed in the survey questions.

Although the textual data, interviews, and surveys were all beneficial, the class observations provided a particularly rich source of material for this project because they 
permitted me to see the ways in which official documents and teacher documents were put into action under particular circumstances with specific groups of students. Because this is a project focusing on classroom practices, the observations allowed me to witness and gather information on the daily happenings in the course and examine these practices in light of the materials gained from other data sources. While the multiple data sources complimented one another and often allowed for a deeper analysis of the happenings of AP English Language and Composition, at times, the multiple data sources resulted in minor inconsistences.

\section{Observations}

Observations for this project occurred at two locations-Blue Meadows High School and Red River High School.

\section{Blue Meadows High School}

I observed two sections of AP English Language and Composition taught by William at Blue Meadows High School. These sections met at the end of the school day. Section one had twenty-nine students and section two had twenty-six students. I observed once a week on an agreed upon day for nine weeks. I conducted six observations in each section. There were three observation days at Blue Meadows High School where I was

unable to observe due to special schedules that altered class times. I stopped observations after the AP English Language and Composition exam and returned during the last week of school to conduct interviews.

William's classroom was a square room with desks arranged in three sections to create a stage area in the middle of the room. For these observations, I was either located in the back corner of the room or the front corner of the room, depending on which white 
board William planned to use for the day's lesson ${ }^{12}$. I was always given a clear view of William and the material being presented during large group discussion. However, I was unable to see a one section of student desks from my position in the front of the room. I arrived at the school approximately ten minutes before the first section began in order to situate myself and not interrupt the daily happenings of the class. Students were aware that I was in the room; however, I had very limited contact with students. While observing at Blue Meadows High School, I took notes in the double entry style described by Heath and Street using legal pads. In one column I had descriptive notes about what was occurring in the class. In the second column, I made notes about connections to theory, other sources, relationships to research questions, etc. In between sections, William often left the room to attend to hall duty or make copies and I was left in the room with students entering and exiting. I was able to talk with students during the five minute passing period. Once the second section was over, I would stay and talk with William informally for ten minutes while the busses cleared out of the parking lot. During this time, William would comment on why he did certain things in the class, talk about what he had done with the students earlier in the year, and what plans he had for the class once they took the AP English Language and Composition exam. These conversations were not recorded but I continued to take notes. I had limited access to the materials that the students used during AP English Language and Composition. Usually, I would be able to review materials during the class session but not provided with hardcopies of documents. When the students were working with materials found on the

\footnotetext{
${ }^{12}$ I mention the set-up of the room and my location during observations because where I was positioned in the room and the ways in which the teacher participants interacted with me in front of the students influenced my relationship with the students.
} 
College Board's website, I was able to access the materials later by taking down the identifying information during the observation and looking it up afterwards.

\section{Red River High School}

I was invited to observe all three sections of AP English Language and Composition that Owen taught at Red River High School. However, because these sections were spread across the school day and I was working at the University of Louisville as a Graduate Teaching Assistant responsible for administrative tasks and teaching one class, we decided that I would observe during a single period. This decision was made for a few reasons. First, Owen had a planning period before this period and a lunch period immediately after. This allowed additional time to discuss what I was observing and other aspects of the course. Second, this section was representative of the student population enrolled in AP English Language and Composition with a mix of traditional AP students and students encouraged to participate because of the school's participation in Advance Kentucky. Third, I was able to observe during this time and arrive to work on-time. I was invited to just show-up any day that I wanted to observe and did not have to give prior notice. There were thirty students enrolled in the section observed. I usually observed twice a week for twelve weeks.

Owen's classroom was a large rectangular room with student desks arranged in two sets so that all desks faced an isle that was created in the middle of the classroom. While I observed, I usually sat in Owen's desk for large class work and moved around to empty student desks when students were working in pairs or small groups. Owen and the students regularly interacted with me during class. I continued to take notes using a double entry journal on legal pads following the same procedures that I used to take notes at Blue Meadows High School. I usually arrived thirty minutes before class started so that 
Owen and I could discuss any questions I had from the prior observation. He would also explain what he would be teaching for the day and provide me with copies of all the materials that the students would be using. These conversations were audio recorded and later transcribed. We also used this time to discuss the outside projects students were working on and Owen's rationale for assigning them, the afterschool supports that were offered at Red River High School, or look at samples of student writing from students with informed consent forms. I also usually stayed fifteen minutes or so after class. During this time, I was able to ask questions about what I had observed and Owen would provide me with an overview of what was happening in the next few classes. These conversations were also recorded and transcribed.

After each set of observations at Blue Meadows High School, I returned to my office at the University of Louisville and reviewed my notes, making additional commentary in the second column. I also typed a brief narrative of each class session and created a list of themes that I saw in the observations for the day. I also located any material from the College Board's website. I printed my follow-up notes, along with any resources from the College Board's website that were utilized during the classes observed. I then filed these documents with my observation notes.

After each observation at Red River High School, I followed the same procedure as when I observed at Blue Meadows High School. However, I crafted follow-up questions to ask Owen. I also made notes about the materials that Owen had shared me with about the structure of the course and the lessons that had occurred during the beginning part of the school year. 
I frequently reviewed my observational notes from both schools throughout the observation period. Through this review, I was able to identify themes that were occurring repeatedly and notice new or developing themes that were consistent with the goals of this project. I attempted to loosely code themes from the observations based on the original research questions for the project. However, I quickly found, my research questions were developing and changing as the project progressed.

\section{Interviews}

\section{Teachers}

All teacher participants were interviewed at their convenience. Interviews took place at their schools and in their classrooms. Upon responding to my IRB approved email solicitation for an interview, participating teachers were asked to indicate days/times that would work to schedule an interview. I had planned for each interview to last between sixty and seventy-five minutes and had prepared an interview script of ten questions ${ }^{13}$ that had received IRB approval. Because I scheduled the interviews at times selected by the participants, I conducted interviews during planning periods, lunch periods, afterschool, and during an AP English Language and Composition course while students were practicing a timed-essay response. All of the interviews took place in the participating teachers' classrooms and were audio recorded and transcribed.

At the start of each interview, I explained the IRB approved consent form and asked all teacher participants to sign informed consent documents. I also gave participants a copy of the informed consent document. After explaining the informed consent and the purpose of this study, I shared with teacher participants three documents that inform this project. These documents are the Frameworkfor Success in

\footnotetext{
${ }^{13}$ See the appendix for a copy of the Teacher Interview Script.
} 
Postsecondary Writing, First-Year Writing: What Good Does It Do?, a policy research document produced by NCTE, and the CWPA Position Statement on Pre-College Credit for Writing. The purpose behind sharing these documents with participants at the beginning of interviews sessions was to establish a foundation for my project and seek to develop a connection with them as teachers of writing. I then started the audio recorder and began with the first interview question. However, I allowed the interviews to flow as natural conversation developed. While the interviews did, at times, get off script, the information that the teacher participants where sharing was valuable to the project. During interviews, teachers also shared resources with me. While I had requested a copy of their AP English Language and Composition syllabus, many teachers shared much more either through copying electronic files or providing me with hardcopy handouts. These documents also caused the interview conversations to drift away from the interview script. However, these unscripted portions of the interviews often provided very rich and nuanced data. Throughout the interviews, I was cautious to keep track of time and redirect the conversation as necessary to be respectful of the participants' time.

I conducted initial interviews with four of the five teacher participants. The fifth teacher participant, William from Blue Meadows High School, was never able to meet for an official interview, although we talked informally on multiple occasions. I also completed five follow-up interviews with Owen at Red River High School. These interviews focused on what I was witnessing through course observations and more about Red River High School's participation in Advance Kentucky. All of these interviews were audio recorded and transcribed. 
Interviews were analyzed using the "Listening Guide" developed in qualitative psychology by Lyn Mikel Brown and Carol Gilligan. Deborah L. Tolman and Mary Brydon-Miller explain that "[t]his method is premised on the role of narrative in organizing human experience and recognizes that there are multiple layers of meaning in experiential narratives, which are (most often) co-constructed in various interview contexts" (7). Additionally, Bronwyn T. Williams explains that this method allows for ways to deal with contradictions that come up while talking with participants and acknowledges "[n]uances in a conversation, such as a prolonged pause, a change in voice tone, and nervous laughter" (39) that can be difficult to analyze from transcriptions. The "Listening Guide" allowed me to listen to the recorded interviews multiple times and focus on a different emphasis each time. Therefore, this method allowed multiple themes and dimensions of the responses to be examined. In listening to the interviews from AP English Language and Composition teachers, I focused on how the teacher described the purpose and function of AP English Language and Composition; the descriptions of assignments, writing pedagogies, and instructional strategies that the teacher commonly includes in his/her classroom practice; the ways in which the writing process is used/viewed in the course; the connections between AP English Language and Composition and college readiness indictors; the relationship(s) between AP English Language and Composition, first-year college writing, and postsecondary writing. I listened to each interview twice and documented the themes indicated above. I then listened to each interview a third time and transcribed word-for-word the responses provided by the participants. After transcribing, I listened to each interview a fourth time to note additional themes and check my transcriptions for accuracy. 


\section{Students}

Students were interviewed at Blue Meadows High School and Red River High School. Student interviews took place after the 2014 AP English Language and Composition exam. I received parental consent from all students interviewed and student assent from the students. Students over the age of eighteen consented for their own participation. Because the informed consent documents had been completed when I began observations several weeks earlier, I started each interview session by reminding students of the documents, providing extra copies, and answering any questions.

At Blue Meadows High School, I conducted fifteen student interviews. These interviews took place in the book/copy/storage room and were occasionally interrupted by people coming into the room to retrieve documents from the printer, make copies, or locate books. William, the AP English Language and Composition teacher at Blue Meadows, explained to students that I was going to be interviewing students. He then sent the students one at a time, alphabetically according to who had turned in consent forms, to me in the book/copy/storage room. I interviewed as many students as possible during the single class period. I used the interview question set ${ }^{14}$ that had been approved by IRB, asking follow-up and clarifying questions as needed, and letting students direct the conversation as much as possible. The student interviews at Blue Meadows High School lasted between four minutes and eight minutes. Student interviews only occurred during this single session at Blue Meadows High School.

At Red River High School, I conducted seventeen student interviews. These interviews took place in an unoccupied classroom. The students in AP English Language and Composition at Red River High School were familiar with me and regularly engaged

\footnotetext{
${ }^{14}$ See the appendix for this document.
} 
in conversations with me by the time I conducted student interviews. Owen, the AP English Language and Composition teacher at Red River High School, allowed me to speak to the whole class to explain that I was finally going to interview them about their experiences and perceptions of AP English Language and Composition. Owen then allowed students, who had already turned in parental consent, to volunteer to be interviewed. So many students volunteered that I came back to Red River High School to conduct additional interviews the following week. I used the interview question set that had been approved by IRB, asking follow-up and clarifying questions as needed, and letting students direct the conversations as much as possible. The student interviews at Red River High School lasted between six and fifteen minutes and often ended with students sharing their expectations about college or asking me questions about my work at the University of Louisville.

I also used the "Listening Guide" to analyze student interviews. In listening to these recordings, I looked for the following: why the student was interested in enrolling in AP English Language and Composition; what the student felt that he/she learned in AP English Language and Composition; how they see enrolling in precollege credit for writing influencing their transition to college; how they understand "rhetoric" and their ability to analyze texts rhetorically; the student's individual experiences with the course. I listened to each interview twice. I then listened to each interview a third time to note themes on a thematic chart and mark possible quotations.

\section{Survey}

The survey for this project was approved by IRB. The purpose of the survey for this study was to gain an indication of students' attitudes and beliefs concerning AP English Language and Composition and first-year writing. All surveys were completed 
anonymously. This data collection tool was used to gain an additional perspective that could be used to triangulate the data collected from observations and interviews. The survey ${ }^{15}$ included six questions. All questions asked students to reflect on their enrollment in AP English Language and Composition and their attitudes towards firstyear college writing. Students indicated their level of agreement on a five-point Likert scale. Only students who had completed the informed consent process were eligible to complete a survey. A total of fifty-nine students completed the survey—-thirty-four from Blue Meadows High School and twenty-five from Red River High School ${ }^{16}$. The mean, median, and mode were determined for each location where survey data was collected, as well as for the combined survey data.

\section{Textual Documents}

In addition to observations and interviews, this study involved textual analysis of material published by the College Board and course documents created by participating teachers. Analysis of foundational documents created by the College Board for AP English Language and Composition occurred to examine the ways in which the class is officially represented. These documents include the Teacher's Guide for AP English, the Course Description for AP English, and released prompts for the AP English Language and Composition exam. Additionally, course syllabi by participating teachers were analyzed to examine the ways in which individual teachers at different locations enact AP English Language and Composition based on the boundary objects provided by the College Board. Course assignments created by participating teachers were looked at to see the ways in which the outcomes for the course were being fostered in assigned work.

\footnotetext{
${ }^{15}$ This document can be found in the appendix.

${ }^{16}$ Survey results can be found in the appendix.
} 
In short, the textual analysis provided additional information on practices that were observed during classroom observations and provided a backdrop for interviews with teachers and students that allowed complications and assumptions to emerge.

\section{Limitations and Ethical Considerations}

While the above sections explain the research tradition followed and my methods and methodology for this study, this section examines a few limitations and ethical considerations arising from my data collection choices.

In "Seduction and Betrayal in Qualitative Research," Thomas Newkirk points out that IRB-approved consent forms often give researchers and their subjects a false sense of ethical security and do not address questions of how participants will be represented in writing about the research. He specifically calls for qualitative researchers "to acknowledge the exploitative potential of qualitative research and to consider guidelines that may do what traditional consent forms clearly fail to do- protect the person being rendered" (4). Newkirk's concern stems partly from the fact that, while participants consent to be part of the study, they have no control over the ways in which the researcher represents their contributions in written representations or oral presentations of the study. In order to minimize possible complications that may arise over the researcher's representation of participants, a few preventative measures can be taken. First, adopting Newkirk's suggestion of having a plan for dealing with bad news is essential when working in settings such as schools where issues such as teaching practices are being examined ${ }^{17}$. Newkirk suggests "that laying out a process for talking about issues at least provides a foundation for later discussion" (13). Even though having

\footnotetext{
${ }^{17}$ Cheri L. Williams also talks about what happens in research projects when "bad news" arises when completing classroom ethnographies.
} 
a plan for dealing with bad news presents a way to deal with issues when they arise, this is a difficult topic to discuss. In my project, my goal was to foster conversations with my research participants, particularly the two classroom teachers, about literacy, college readiness, writing instruction, AP English, and first-year writing. However, I was also aware of the pressures that AP English Language teachers are facing from state, district, and school levels and the ways in which this pressure has the possibility of influencing instructional practices. Yet, I also believed that the teachers participating in my research would want to know what else they can do to prepare their students for college writing and that bad news might be taken as an opportunity to examine the situation to better serve students. In short, while I approached the issue of bad news before beginning observations with both of my teacher participants, this was not an issue that arose during the observation period. This was not a major issue partly because of the open lines of communication that I shared with the teacher participants. We were already having conversations about classroom practices and pedagogical strategies so that when questions arose we were able to focus the conversations on discussing the purposes and function on specific practices and strategies. However, after school year concluded, the relationship with one teacher lapsed before I was able to finish data collection.

The issue of transparency also had to be addressed during my research process. In an effort to be as transparent as possible, I shared details of my project with the classroom teachers before I began collecting data. This mostly took the form of sharing documents, such as the Framework for Success in Postsecondary Writing, What Good Does First-Year Writing Do? and the CWPA Position Statement on Precollege Credit for Writing, and discussing the purpose of my project in relation to these documents. I also 
shared interview and survey questions with the teacher participants before using these data collection tools with students. My hope was that by sharing my plans and rationale behind my decisions that participants would have a better understanding of what I was trying to accomplish with my project and this would provide some type of rationale for why I was asking about certain aspects of classroom practice. I also hoped that being deliberate and explicit about my goals would lead to my participants sharing materials that fit within my goals. In addition to being specific concerning my goals before beginning observations, I also agree with Newkirk that "[t]he researcher should grant the teacher (and, when relevant, her students) the opportunity to respond to interpretations of problematical situations...ideally these exchanges should be part of the data gathering and not be postponed for the time when a full manuscript has been prepared" (13). Therefore, as I was collecting data I was also talking with Owen from Red River High School and William from Blue Meadows High School about the practices that I was observing in their courses. Throughout the observation period, I would offer my analysis as to why I suspected some practices were being included and they would either confirm or deny my speculations and explain the function of certain learning practices and pedagogical strategies from their perspective. These exchanges were invaluable in my research. My participants will also be offered the opportunity to read my completed dissertation when the project has been approved by my committee.

While issues concerning the researcher's relationship to her participants and transparency of practice are important, Patricia Sullivan further reminds researchers to consider issues of representation when rendering participants in writing. In "Ethnography and the Problem of the 'Other,"' she points out that composition researchers very often 
invert the terms of ethnography because we are often investigating a site or community where we also hold membership. While, traditionally, the goal of ethnography has been to make the strange familiar, composition researchers invert this goal and make the familiar, everyday practices strange. I kept this in mind as I was collecting data and drafting chapters, especially since I am also a writing teacher and I went into these classrooms to study the practices of other writing teachers. Representing my participants fairly and in ways that appropriately convey their practices are concerns that I continually revisited throughout this project. In order to address these concerns, I regularly reflected on my interpretation of the practices that I observed and discussed these with participants and colleagues. 


\section{CHAPTER 3: COLLEGE READINESS, THE FRAMEWORK FOR SUCCESS IN POSTSECONDARY WRITING, AND AP ENGLISH LANGUAGE AND COMPOSITION}

"Habits of mind — ways of approaching learning that are both intellectual and practicalare crucial for all college-level learners. Beyond knowing particular facts or completing mandatory readings, students who develop these habits of mind approach learning from an active stance. These habits help students succeed in a variety of fields and disciplines. They are cultivated both inside and outside school. Teachers can do much to develop activities and assignments that foster the kind of thinking that lies behind these habits and prepare students for the learning they will experience in college and beyond." (527)

Framework for Success in Postsecondary Writing

"Overall, I would like to see high school students begin to think about college readiness in ways that focus not on test scores or particular curricular achievements and skill sets, but on dispositional qualities and character traits." (550)

$\sim$ Patrick Sullivan

"Our desire is to make curriculum, instruction, and assessment more balanced so that students have the opportunity to learn, practice, and demonstrate the development of dispositions. We want our children to develop those dispositions that lead them to become lifelong learners, effective problem solvers and decision makers, able to 
communicate with a diverse population and to understand how to live successfully in a rapidly changing, high-tech world. " (15-16)

\section{$\sim$ Arthur L. Costa and Bena Kallick}

These three quotations illustrate the often unspoken aspect of preparing secondary students to enter sites of postsecondary education - the cultivation of dispositions that will provide success in college and beyond. When viewed through the lens of developing dispositions, the conversation shifts from meeting outcomes and developing skills to cultivating character traits that lead to success in multiple situations. While the opening quotes represent multiple perspectives on the issue of cultivating dispositions, they agree that students with particular types of experiences and habits experience increased levels of success in college, thus, pointing to the fact that college readiness is about more than meeting benchmarks on standardized assessments. It is about learning to learn and approaching learning in particular ways.

The first quotation, found in the Framework for Success in Postsecondary Writing $^{18}$ created by the Council of Writing Program Administrators, the National Council of Teachers of English, and the National Writing Project, positions learning as an active experience that includes more than the acquisition of content knowledge and skills. The kind of learning advocated for in the Framework calls on students to develop "ways of approaching learning" that will serve them in multiple ways in college and after graduation. Endorsed by organizations holding positions of authority in the teaching of writing, this quote explicitly connects college readiness and dispositional qualities. And, working from the standpoint that preparing students for college is a K-16 endeavor, the Framework seeks to connect skills with dispositions that students will have started to

\footnotetext{
18 This document is referred to as the Framework from this point forward.
} 
develop in secondary school writing experiences that they will continue to develop in postsecondary writing experiences.

The second quotation by Patrick Sullivan, in "Essential Habits of Mind for College Readiness," responds to the Framework's call for the development of habits of mind among students. Sullivan calls attention to the differences that exist between developing skills and developing dispositions. For Sullivan, the concept of college readiness encompasses much more than a score-meeting benchmark, and, even though the Framework specifically links the identified habits of mind to particular writing experiences, the qualities that will assist students in being successful in multiple situations.

In the third quotation, Arthur L. Costa and Bene Kallick relate the learning experiences typical of educational settings to the development of dispositions to indicate the larger implications of fostering certain dispositional qualities in students. Coming from the perspective of researchers with many years working with scholarship on qualities of successfulness, Costa and Kallick speak to the versatility that well-cultivated dispositions afford students in college and beyond.

While it has become commonplace, especially since the implementation of the Common Core State Standards in 2009, to focus educational conversations on conceptions of college readiness, these conversations typically focus on students either being, or more commonly, not being college ready according to standardized assessments and the implications of this status for students and schools. The focus is on scores, on benchmarks, and not necessarily on what scores and benchmarks indicate about potential success for the student in postsecondary education. This chapter addresses the ways in 
with AP English Language and Composition is about more than passing the exam at the end of the course because the course fosters dispositions that prepare students for college through sponsoring particular types of literacy experiences ${ }^{19}$. In short, while typical conversations about AP English center on the course as an option for precollege credit for writing, I argue that when the emphasis is on learning and exposing as many students as possible to the challenging curriculum, AP English Language and Composition is designed to provide a learning environment that promotes college readiness by encouraging the development of dispositions that have been linked with success. Thus, this chapter begins to address AP English Language and Composition in terms of the learning environment that the course has the potential to create when the emphasis shifts away from assessment and towards a different orientation toward learning that focuses on the development of dispositions that students will be able to use in the future. This chapter shows the connection between the AP English Language and Composition outcomes, WPA OS, and the dispositions identified in the Framework in order to set up the investigation of the ways in which AP English Language and Composition cultivate dispositions through literacy experiences across Jefferson County Public Schools that follows in chapter four.

\section{College Readiness and Advanced Placement}

First-year composition started as a remediation tool to address the students who were not meeting the college readiness standards for Harvard in 1874. Despite the fact that what it means to be "college ready" has greatly evolved, the current argument surrounding the topic remains eerily similar to early conversations surrounding the

\footnotetext{
${ }^{19}$ As explained in chapter one, I am following Brandt's notion of literacy sponsorship. Brandt argues that literacy sponsors "are any agents, local or distant, concrete or abstract, who enable, support, teach, model, as well as recruit, regulate, suppress, or withhold literacy — and again advantage by it in some way" (166).
} 
implementation of first-year writing courses. Postsecondary institutions continue to insist that a number of students are not ready to enroll in college level coursework because of a lack of necessary skills. However, in recent years, this issue has gained increased attention with the creation and adoption of the Common Core State Standards ${ }^{20}$. College readiness has increasingly become a marker, a tool used to classify students. Not only have conversations concerning college readiness exploded with the Common Core State Standards initiative, but efforts are being made at national, state, and local levels to clearly define what it means for a student exiting secondary education and entering a postsecondary institution to be college ready. The goal behind this movement is for remediation to occur before students enter postsecondary institutions. Particularly, in Kentucky college readiness is defined as "the level of preparation a first-time student needs in order to succeed in credit-bearing courses at a postsecondary institution. 'Succeed' is defined as completing entry-level courses at a level of understanding and proficiency that prepares the student for subsequent courses" (Unified Strategy for College and Career Readiness 7). College readiness is measured through standardized tests, such as the ACT, and other placement tests approved by the state ${ }^{21}$.

In order to promote college readiness by preparing students to enter postsecondary institutions without the need for remediation, the state of Kentucky began working on several approaches to increase the number of high school seniors that are college ready. These include Accelerated Learning Opportunities, Secondary Intervention Programs, College and Career Readiness Advising, and Postsecondary College

\footnotetext{
${ }^{20}$ The Common Core State Standards is referred to Senate Bill 1 or Unbridled Learning in the state of Kentucky. It is also important to note that Kentucky was the first state to sign on to the CCSS initiative in 2009.

${ }^{21}$ Currently, an ACT sub score of 18 in English and 20 in Reading makes a student college ready in Kentucky.
} 
Persistence and Degree Completion (Unified Strategy for College and Career Readiness 3). Of particular importance for this project is the first strategy because it is "focusing on the expansion of AP/IB access and dual credit opportunities" (3). With this approach, the Kentucky Department of Education has identified three goals, all of which are important to the conversation concerning precollege credit for writing but goal one is of particular importance because it directly relates to the AP program. Goal one states that " $[\mathrm{b}] \mathrm{y}$ August 2014, all students will have access to Advanced Placement (AP), International Baccalaureate (IB), or other accelerated learning opportunities. Student success in accelerated learning opportunities will increase" (Unified Strategy for College and Career Readiness 10). Moreover, the Kentucky Department of Education has identified three sub goals that impact the ways in which literacy is being sponsored in AP English courses.

Sub goal 1.1.4 states that "Kentucky will reach or exceed the national average for the number of students in a graduating class taking at least one AP exam in their high school career" and the expected outcome is that "[m]ore students will take AP exams in Kentucky schools" (Unified Strategy for College and Career Readiness 11). Sub goal 1.1.4 also states that not only is it expected that more students will take AP courses and exams but that "Kentucky will reach or exceed the national average for students who score a 3 or higher on at least one AP exam in high school" (Unified Strategy for College and Career Readiness 11). While sub goal 1.1.4 focuses on increasing the number of students experiencing the AP curriculum and benefits associated with it, sub goal 1.1.5 addresses preparing teachers to handle the increase number of students enrolled in AP courses. It states that "Seventy-five percent (75\%) of Kentucky's school districts will have access to an Advanced Kentucky AP teacher training and incentive program" and 
the expected outcome is that since " $[\mathrm{m}]$ ore teachers will be trained to deliver AP courses [,] [m]ore students will take AP exams" (Unified Strategy for College and Career Readiness 11). While sub goals 1.1.4 and 1.1.5 address increasing enrollment and preparing teachers to handle this increase, sub goal 1.1.7 addresses changing the ways in which AP is viewed to allow a larger population of students the opportunity for enrollment. Sub goal 1.1.7 states that "[a]11 districts will have an open enrollment policy for $\mathrm{AP} / \mathrm{IB} /$ dual enrollment, and schools will implement district policies" with the expected outcome that "[s]chools will remove barriers to student participation in accelerated learning opportunities" (Unified Strategy for College and Career Readiness 11).

While the AP program originally sought to jump start the college experience for gifted students and first-year writing sought to provide remedial instruction to make sure entering students would be capable of completing college level coursework, the conversations connecting these things have converged in recent years under the heading of college readiness. The underlying goal of AP English Language and Composition and first-year writing is to provide students with the tools they need to be successful in college level writing. Yet, the term college readiness is not new, and as the development of the first-year writing course at Harvard in 1874 demonstrates, nor is the argument that students are coming to college without the necessary skills to succeed.

A search of EBSCO Academic Search Premier, EBSCO ERIC, and JSTOR show that the term "college readiness" has occupied and continues to occupy an increasingly popular place in scholarship surrounding K-12 education and postsecondary education. The results combined for a search of "college readiness" show that there are 1,826 
returns. When narrowed to include only scholarly sources the number of returns drops to 569. In fact, the earliest use of the term appeared in $1944^{22}$ in discussions of a general education curriculum for college education. The term continues to appear sporadically up until the 1990s when its frequency becomes more consistent. The steady increase continues in the early 2000s as schools implement the 2001 No Child Left Behind reform. However, it is important to note that there is a striking increase of the term in scholarship after 2009 when the Common Core State Standards begins to place a high emphasis on college readiness. This shows us not only the sheer volume of work being done both in popular and scholarly settings on college readiness but also allows the recent influx to be noted. College readiness, while not a new idea, is at the center of educational conversations.

The recent influx of attention to college readiness in popular and scholarly writing is connected to the Common Core State Standards ${ }^{23}$. Created in 2009 to respond to the lack of consistent educational standards between states, the development of the CCSS was led by "the nation's governors and education commissioners" in order to "ensure that all students have the skills and knowledge necessary to succeed in college, career, and life upon graduation from high school, regardless of where they live" $(1)^{24}$. Additionally, the CCSS "enables collaboration among states on a range of tools and policies" (1). This collaboration has the possibility to extend from textbooks to teaching materials to common assessments. One such consistent measure that many states have adopted to measure college readiness is benchmark scores on the ACT exam. Another such

\footnotetext{
${ }^{22}$ Koos, Leonard V. "The Record of a Notable General-Education Program." The School Review. 52.6 (1944): 376-377. JSTOR.

${ }^{23}$ Also referred to as the CCSS.

${ }^{24}$ From the Common Core State Standards Initiative Frequently Asked Questions found at: http://www.corestandards.org/about-the-standards/frequently-asked-questions/
} 
consistent program that already existed nationwide is the AP program developed and administered by the College Board. Under past conceptions of AP courses, the terms college readiness and AP could have been used interchangeably; as I explain in chapter one, the original intention of the AP program was to serve gifted students who were not being challenged enough by high school curriculum and used AP courses as an opportunity to experience a more rigorous curriculum and potentially gain college credit. Under this system, only the best and brightest students enrolled in AP courses. However, the purpose and function of AP is changing under the push for college readiness and current educational initiatives. While the goal of college readiness seeks to reach students who were not traditionally served by the College Board's AP program, the proven benefits of the rigorous curriculum associated with AP courses has presented itself as a way to challenge students, prepare them for college, and get them ready to meet college readiness benchmarks. ${ }^{25}$ Gatekeeping measures that once kept AP courses reserved for the elite are being removed and replaced with an open enrollment model where all students are encouraged to enroll for the type of college preparation that AP courses afford. Despite the fact that college readiness is currently measured by benchmark scores on standardized tests in the state of Kentucky, college readiness indirectly indicates that the student has developed certain dispositions that will assist them as they transition to postsecondary educational institutions and these dispositions are fostered by the AP English Language and Composition curriculum.

In order for students to become college ready, they need to be able to employ and deploy tactics and strategies, not just skills, to navigate and negotiate complex literacy experiences, such as the ones they come into contact with and learn to negotiate through

\footnotetext{
${ }^{25}$ I look at this issue in more depth in the case study of Red River High School in chapter seven.
} 
AP English Language and Composition and first-year composition. The ways in which literacy is promoted in first-year writing courses and in the AP English Language and Composition course work to promote college readiness during the first year of postsecondary education and while students are still enrolled in secondary education. These two programs should not be seen as having conflicting values, despite the fact that they were created to serve different populations of students. Instead, AP English Language and Composition can be viewed as one possible curriculum that allows students the experiences that they need to become college ready. For this particular population of students, they do not necessarily seek out AP English Language and Composition as a precollege credit option but as a site to develop the literacy necessary to be rendered college ready. In short, they enroll in the course in order to cultivate and develop dispositions and skills that will allow them to be successful in first-year college writing courses when they enter postsecondary education.

\section{The Framework for Success in Postsecondary Writing}

In January 2011, the Council of Writing Program Administrators, the National Council of Teachers of English, and the National Writing Project worked together to develop the Framework for Success in Postsecondary Writing. This document was created in response to the realization by NCTE, CWPA, and NWP that while they shared the joint goal of preparing students to enter postsecondary institutions prepared to write, a joint conversation between K-12 and postsecondary teachers of writing was absent from the conversation. In "Creating the Framework for Success on Postsecondary Writing" Peggy O’Neill, Linda Adler-Kassner, Cathy Fleischer, and Anne-Marie Hall point out that three beliefs underlie the document. The first belief "is that writing instruction is an 
activity shared by k-16 teachers" (520). The second belief is that " 'college readiness' in writing should be defined jointly by instructors in two- and four-year postsecondary classrooms and high school teachers who had those classrooms in mind as they worked with students in grades 9-12" (520-521). Third, representatives from NCTE, CWPA, and NWP "agreed that a collaborative statement from them would represent college and career readiness in the area of writing more accurately than would other attempts to articulate this concept, because such a statement would draw on both the experiences of K-16 teachers and research on writing instruction, especially in the postsecondary years" (521). In addition to these beliefs, the task force also worked within the framework provided by the Common Core State Standards because "[f]rom the onset of the discussion about the Common Core State Standards (CCSS), it was clear that the Standards outlined in that document would significantly affect the writing experiences that students would have before entering college" (522). However, as O’Neill et al point out, "although the writing standards in the CCSS are intended to ensure that students are 'college ready,' the absence of the voices of college writing teachers and researchers from the committees developing the Standards was striking from the beginning" (522). With these beliefs at its foundation and multiple voices from stakeholders ${ }^{26}$ at various levels, the taskforce created the Framework "to focus on what students need to know and

\footnotetext{
${ }^{26}$ In "Creating the Framework for Success in Postsecondary Writing" Peggy O'Neill, Linda Adler-Kassner, Cathy Fleischer, and Anne-Marie Hall explain that "In August, leaders of CWPA, NCTE, and NWP provided us with additional feedback on the draft, and we made a new round of revisions that reflected their concerns. In September, the organizations' leaders approved a draft of the Framework to be used for gathering feedback from writing teachers. During the fall of 2010, we collected feedback on the Framework draft from focus groups that included a variety of secondary teachers funded by NWP, as well as from high school and college instructors in sessions at professional conferences. This feedback provided by several hundred teachers was invaluable in helping us refine the final draft and make plans for promoting the document" (523).
} 
be able to do at the beginning of the first-year course so they could reach the outcomes" (522).

The Framework is comprised of two parts: Habits of Mind and Experiences with Writing, Reading, and Critical Analysis. The first part explains that "[h]abits of mind refers to ways of approaching learning that are both intellectual and practical and that will support students' success in a variety of fields and disciplines" (525). It continues to state that "[t]eachers can do much to develop activities and assignments that foster the kind of thinking that lies behind these habits and prepare students for the learning they will experience in college and beyond" (527). The second part explains that "[p]articular writing, reading, and critical analysis experiences contribute to habits of mind" (529). These experiences are in line with the WPA OS. The Framework also explains that because it is "concerned primarily with foundations for college-level, credit-bearing writing courses, it is based on outcomes included in the CWPA Outcomes Statement for First-Year Composition" (527). The ways in which the eight habits of mind identified in the Framework are incorporated in the literacy experiences of AP English Language and Composition has yet to be investigated, even though "[t]his Framework identifies the habits of mind and the kinds of writing experiences that will best prepare students for success as they enter" first-year writing courses (3). One way of considering the ways in which literacy is being fostered within AP English Language and Composition is to examine how and where evidence of the eight habits are present in the foundational documents. However, before moving to this investigation, it is important to consider the history, affordances, and limitations of the Framework because the circumstances 
surrounding the document contribute to its validity and argue for its usefulness as a tool for preparing students for postsecondary writing experiences.

\section{Affordances of the Framework}

The Framework offers many affordances for investigating AP English Language and Composition because it allows the dispositions being cultivated to be separated from course outcomes, even though developing the dispositions also lead to meeting the outcomes. This separation is important because the purpose of AP courses is complicated by open enrollment and initiatives to enroll nontraditional students in AP courses. Open enrollment is a complicating factor because with changing demographics and more students enrolling, not as many students will leave AP courses, such as AP English Language and Composition, having gained mastery over the outcomes. Thus, as the outcomes are met to varying degrees by different populations of students, the outcomes alone are not enough to ensure sufficient college preparation, especially when the goal of enrolling in AP coursework may not be to gain college credit but to gain increased preparation for college. But, a curriculum, such as AP English Language and Composition, that is also promoting dispositions would offer sufficient preparation for students looking not necessarily for college credit from AP English Language and Composition but college preparation. In short, the Framework focuses on dispositions that have the potential to benefit students across disciplines and in college in general, while the outcomes for AP English Language and Composition focus on skills that are relatable to first-year writing. All students enrolled in AP English Language and Composition benefit from the dispositions cultivated and the outcomes. Additionally, the Framework provides a different orientation towards learning that focuses more on concepts of learning rather than on emphasizing assessment. Historically, as addressed in 
chapter one, conversations concerning AP English have centered around the question of granting college credit based on student performance on the AP exam. Thus, the Framework allows AP to be discussed as an environment for learning where the consideration is on what learning is taking place within the course, why such learning is occurring, and works to distance the course from the AP exam.

\section{The History of Linking the Habits of Mind and Success}

Before moving to examining the ways in which the eight habits from the Framework intersect with course outcomes for AP English Language and Composition, it is important to take a moment and explore where the eight habits come from and how the cultivation of these dispositions increases the potential for success. While Judith Summerfield and Philip M. Anderson point out the origin of the habits of mind in their critique of the Framework, the Framework does not provide any indication of where the eight habits originated. However, there is a long history associated with habits of mind that extends back to 1982 with Arthur Costa, and even further to John Dewy in 1933 with his "habits of thought" (Perkins vii). Most of the work completed on habits of mind in the last thirty years has occurred in education and been under the direction of Arthur Costa and Bene Kallick. Their work has been informed by various theories concerning intelligence, such as structural intelligence (Wimbey, Wimbey, and Shaw), multiple intelligence (Gardner), emotional intelligence (Goleman) and moral intelligence (Cole). An abbreviation of this work appears to provide the foundation for the eight habits of mind included in the Framework ${ }^{27}$.

\footnotetext{
${ }^{27}$ For more information about the sixteen habits of mind in Costa and Kallick's work see: Learning and Leading with Habits of Mind.
} 


\section{Connections Between the Habits of Mind and Critical Thinking Initiatives}

Not only are the eight habits of mind rooted in other work that has a long history in education, they also overlap with critical thinking initiatives adopted by universities across the country. For example, the University of Louisville's critical thinking initiative adopted the Paul-Elder Critical Thinking Model, and the Intellectual Traits that are part of this model closely resemble the dispositions fostered through the eight habits of mind. These intellectual traits include humility, autonomy, fair-mindedness, courage, perseverance, empathy, integrity, and confidence in reasoning. According to The Miniature Guide to Critical Thinking Concepts and Tools, "[h]abitual utilization of the intellectual traits produce a well-cultivated thinker [that will] raise vital questions and problems... [gather and assess relevant information...come to well-reasoned conclusions and solutions...think open-mindedly within alternative systems of thought...[and] communicate effectively with others" (xx). Not only does the University of Louisville follow the Paul-Eder Model of Critical Thinking, but many other school systems, colleges, and universities do as well. These include Surry Community College in Dobson, North Carolina, Wilkes Community College in Wilkesboro, North Carolina, Eastern Kentucky University, the Lampton School in London, United Kingdom, the Thompson School District in Loveland, Colorado, and Beacon College in Leesburg, Florida ${ }^{28}$. The traits found in critical thinking initiatives reinforce and call for students to develop dispositions that are very similar to the dispositions called for by the Framework. Therefore, because many postsecondary institutions explicitly promote critical thinking and the habits included in the Framework overlap with critical thinking traits, students

\footnotetext{
${ }^{28}$ Information obtained from the Foundation for Critical Thinking. Last updated 3/2010.
} 
are entering postsecondary institutions with a potential advantage because they already started to develop the necessary skills and habits for success.

\section{Critiques of the Framework}

Before using the Framework to explore AP English Language and Composition, it is also important to note some of the limitations that it brings. While the document has largely received a positive response from teachers and scholars, a few concerns have been raised. Carol Severino identifies several possible negative consequences of the Framework. She points out that high school teachers are already overworked "teaching five classes and 100-plus students whose literacy skills range from college level to minimal" (533) and the that majority of high school English courses focus on literature. She also argues that "it makes more sense in terms of setting, timing, and exigency for students to take the course that prepares them for writing they do in college, when they are fully matriculated in college" (533-534). She also "[w]orr[ies] that this articulation enterprise will continue to widen the gap between students from wealthier, middle-class schools and those from poorer schools, especially schools with greater proportions of students who are dialect speakers or second language speakers of English" (534). Despite these criticisms, Serverino does praise the Framework because it "demystifies for high school teachers, their students, and their students' parents these habits and experiences so they can take more control of their teaching, learning, and coaching lives" (534). It is important to note that Serverino is not alone in expressing concerns over the Framework. Servino's critique is important to this study because she acknowledges drawbacks potentially associated with the Framework that need to be considered when using it to examine the ways in which precollege credit for writing alternatives prepare students for postsecondary writing experiences. 
Bruce McComiskey also raises some concerns over the function and purpose of the Framework because of its similarity to other documents already in existence. $\mathrm{He}$ points out that "the Framework will never have the institutional clout that the CCSS already has" (538). However, he continues to say that "if the Framework is viewed as additional support for the CCSS...then it should have some impact on secondary education and the preparation of high school students for the rigors of college writing" (538). He also points out that "[t]he Framework ... is different from the CPWA Outcomes Statement but not radically so" (538). Yet, he sees promise in the Framework for its ability to act "as a bridge between the CCSS and the CWPA Outcomes Statement" (538). While secondary teachers of writing are already overwhelmed by policy documents and guidelines, the Framework appears to seek a different orientation towards learning that has the potential to expand success outside of the classroom.

While Serverino focuses on possible negative outcomes of the Framework and McComiskey works to locate the document in relation to other documents circulating in the discipline, Kristine Hansen questions the connection between the eight habits and preparing students to write in college. She claims that she "heartily approve[s] of the Framework's emphasis on developing students' habits of mind as a major goal of education" (540). Yet, she argues that “"college readiness' in writing and reading does not depend on habits of mind so much as it depends on many diverse experiences with rhetoric, critical thinking and writing processes" (541). She continues to argue that the focus should be on helping students continue to develop as they engage with writing experiences in first-year college writing courses. Thus, just because a student has developed the dispositions outlined by the eight habits does not mean that he or she is 
ready to bypass first-year writing because these dispositions may be further developed by the first-year composition experience. Hansen's critique is relevant to this project because this investigation seeks to show alignment between the habits of mind, AP English Language and Composition outcomes, and instructional practices found in a variety of AP English Language and Composition courses.

I have examined the Framework, its affordances and limitations in order to lay the foundation for examining the ways in which the habits of mind overlap with outcomes for AP English Language and Composition. In what follows, I argue that not only does this overlap exist but it is an important aspect of the learning experience that students encounter in AP English Language and Composition because the cultivation of dispositions better prepare students for postsecondary writing experiences. While I realize that policy statements and course documents do not guarantee practices, they do offer insights into goals and expectations that are important to consider. Additionally, classroom practices will be discussed in chapters five, six, and seven.

\section{AP English Language and Composition Preparing Students for Postsecondary} Writing

The College Board introduces AP English Language and Composition to prospective students in the following statement:

An AP course in English Language and Composition engages students in becoming skilled readers of prose written in a variety of rhetorical contexts, and in becoming skilled writers who compose for a variety of purposes. Both their writing and their reading should make students aware of the interactions among a writer's purposes, audience expectations, and 
subjects, as well as the way genre conventions and the resources of language contribute to effectiveness in writing.

\section{(Course Description 7)}

Based on the above course description and other descriptions produced by the College Board, it can be concluded that AP English Language and Composition is designed to help students become the type of readers and writers that will allow them to be successful in future educational and life experiences. Students completing the course will not just be proficient in reading and writing in educational contexts but "in a variety of rhetorical contexts" and "for a variety of purposes" (7). Throughout the course, students gain insight and experience into analyzing how what they write and what others write interact with the audience in order to increase their effectiveness as both readers and writers.

In addition to the course description, the College Board clearly outlines three goals for AP English Language and Composition, and these goals work to promote literacy in specific ways. The first goal centers on students' ability to read and write texts. It states that "the purpose... is to enable students to read complex texts with understanding and to write prose of sufficient richness and complexity to communicate effectively with mature readers" (7). Complexity is a key issue in this goal. Students are expected to move beyond basic comprehension and response to a level that shows they have a deeper understanding of the issues at hand. The second goal also builds on the idea of complexity. It states that the "course should help students move beyond such programmatic responses as the five-paragraph essay [because] they often encourage unnecessary repetition and fail to engage the reader" (7). Again, the goal stresses that students need to move past the basic level of understanding and to a level where they are 
critically engaging with material on a deep and meaningful level. However, it seems interesting that while the course description specifically cautions against the dangers of the five paragraph essay and boasts that students in AP English courses learn to write at more complex levels, the essay portion of the exam is very often answered quite effectively using the five-paragraph essay model. The third goal focuses on allowing students to use the rhetorical situation to help guide the organization of their composition. It states that "[s]tudents should be encouraged to place their emphasis on content, purpose and audience and to allow this focus to guide the organization of their writing" (7). This last goal clearly supports the rhetorical approach that the course uses as its foundation. The course encourages student to break away from models and templates for their writing and expand possibilities by considering the different needs and anticipations of their audience and situation. Breaking away from these models requires a level of skill that is promoted through the curriculum of AP English Language and Composition.

The types of literacy experiences that are supported in AP English Language and Composition are laid out in even more detail when the outcome statements for the course are investigated. The course description explains that at the completion of the course students should be able to demonstrate competency in the following twelve outcomes:

- Analyze and interpret samples of good writing, identifying and explaining an author's use of rhetorical strategies and techniques

- Apply effective strategies and techniques in their own writing

- Create and sustain arguments based on readings, research and/or personal experience

- Write for a variety of purposes 
- Produce expository, analytical and argumentative compositions that introduce a complex central idea and develop it with appropriate evidence drawn from primary and/or secondary sources, cogent explanations and clear transitions

- Demonstrate understanding and mastery of standard written English as well as stylistic maturity in their own writings

- Demonstrate understanding of the conventions of citing primary and secondary sources

- Move effectively through the stages of the writing process, with careful attention to inquiry and research, drafting, revising, editing, and review

- Write thoughtfully about their own process of composition

- Revise a work to make it suitable for a different audience

- Analyze image as text

- Evaluate and incorporate reference documents into researched papers From an outcomes standpoint, AP English Language and Composition aligns with the outcomes of first-year writing as outlined by the WPA OS very well, as Kathleen M. Puhr successfully demonstrates in "The Evolution of AP English Language and Composition" and as David Jolliffe shows in the Teacher's Guide section he authors on "College Composition: Goals, Outcomes, Innovations" (4-6). While Puhr lists the WPA OS and the outcomes for AP English Language and Composition side-by-side to draw attention to the numerous similarities, a quick comparison and categorization of the WPA OS and the 
AP English Language and Composition outcomes make the similarities even more apparent. For example, I constructed the following table:

Table 1: WPA OS \& AP English Language and Composition Outcomes

\begin{tabular}{|c|c|}
\hline WPA OS & $\begin{array}{l}\text { AP English Language \& Composition } \\
\text { Outcomes }\end{array}$ \\
\hline Rhetorical Knowledge & $\begin{array}{l}\text { - Analyze and interpret samples of } \\
\text { good writing, identifying and explaining } \\
\text { an author's use of rhetorical strategies } \\
\text { and techniques } \\
\text { - Apply effective strategies and } \\
\text { techniques in their own writing } \\
\text { - Create and sustain arguments based } \\
\text { on readings, research and/or personal } \\
\text { experience } \\
\text { - Write for a variety of purposes } \\
\text { - } \quad \text { Produce expository, analytical and } \\
\text { argumentative compositions that } \\
\text { introduce a complex central idea and } \\
\text { develop it with appropriate evidence } \\
\text { drawn from primary and/or secondary } \\
\text { sources, cogent explanations and clear } \\
\text { transitions } \\
\text { - } \quad \text { Revise a work to make it suitable for } \\
\text { a different audience } \\
\text { - } \quad \text { Analyze image as text } \\
\text { - Evaluate and incorporate reference } \\
\text { documents into researched papers }\end{array}$ \\
\hline Critical Thinking, Reading and Writing & $\begin{array}{l}\text { - Analyze and interpret samples of } \\
\text { good writing, identifying and explaining } \\
\text { an author's use of rhetorical strategies } \\
\text { and techniques } \\
\text { - Create and sustain arguments based } \\
\text { on readings, research and/or personal } \\
\text { experience } \\
\text { - Produce expository, analytical and } \\
\text { argumentative compositions that } \\
\text { introduce a complex central idea and } \\
\text { develop it with appropriate evidence } \\
\text { drawn from primary and/or secondary } \\
\text { sources, cogent explanations and clear } \\
\text { transitions } \\
\text { - Analyze image as text }\end{array}$ \\
\hline
\end{tabular}




\begin{tabular}{|c|c|}
\hline Processes & $\begin{array}{l}\text { - Move effectively through the stages } \\
\text { of the writing process, with careful } \\
\text { attention to inquiry and research, } \\
\text { drafting, revising, editing, and review } \\
\text { - Write thoughtfully about their own } \\
\text { process of composition } \\
\text { - Revise a work to make it suitable for } \\
\text { a different audience }\end{array}$ \\
\hline Knowledge of Conventions & $\begin{array}{l}\text { - Demonstrate understanding and } \\
\text { mastery of standard written English as } \\
\text { well as stylistic maturity in their own } \\
\text { writings } \\
\text { - Demonstrate understanding of the } \\
\text { conventions of citing primary and } \\
\text { secondary sources } \\
\text { - Evaluate and incorporate reference } \\
\text { documents into researched papers }\end{array}$ \\
\hline Composing in Electronic Environments & N/A \\
\hline
\end{tabular}

With this visual mapping, it is very apparent that the AP English Language and Composition outcomes map directly on to the WPA OS. The only exception is the WPA OS dealing with Composing in Electronic Environment that was added in 2008.

Even though alignment exists between the outcomes, the ways in which different settings encourage literacy and promote the eight habits of mind has not been addressed. These are important issues to consider because students are enrolling in this course to prepare to enter the postsecondary institution of their choice and possibly as a substitute for first-year composition. Therefore, the following analysis examines the ways in which the outcomes for AP English Language and Composition intersect with the dispositions that the Framework identifies as being essential for student success. The dispositions present in the eight habits of mind are already associated with the WPA OS and this analysis extends the conversation by taking a more in-depth look at the ways in which the eight habits overlap with the foundational documents for AP English Language and 
Composition. I argue that intersections between the dispositions and the outcomes are present and important because these connections indicate alignment between specific skills associated with the course and the larger rationale for learning that underlies AP courses, which seeks to cultivate a foundation of success that allows students to experience an easy transition from secondary to postsecondary coursework. In short, students that have begun to develop these dispositions will potentially experience greater success in postsecondary education. Therefore, because of the relationship that exists between certain dispositions, AP English Language and Composition outcomes, and success, I argue that students needs to be offered opportunities to develop these traits and enrollment in AP English Language and Composition offers this opportunity.

\section{Dispositions and AP English Language and Composition Outcomes}

The eight habits of mind identified in the Framework are fostered in multiple ways in AP English Language and Composition. The discussion in this section begins to explore some of these possibilities by pointing out potential points of alignment between the dispositions identified in the Framework and the outcomes for AP English Language and Composition. Using the criteria outlined for each disposition in the Framework and the outcomes identified in the official course documents produced by the College Board, in what follows, I map out alignment between the AP English Language and Composition outcomes and the criteria that the Framework identifies for each disposition in order to show that the course has the potential to successfully prepare students for postsecondary writing experiences. 


\section{Curiosity}

According to the Framework, students demonstrate curiosity when they ask questions that are appropriate for real-world audiences in multiple contexts. They continue to exhibit curiosity as they use discipline specific research methods to locate and use sources responsibly to answer the questions that they have formulated. In addition, students show curiosity when they use discipline specific conventions to express their research findings to a variety of real-world audiences. The following table depicts the outcomes for AP English Language and Composition that potentially encourage students to be curious.

Table 2: Curiosity \& AP English Language and Composition Outcomes

\begin{tabular}{|c|c|}
\hline Habit of Mind & $\begin{array}{c}\text { AP English Language and Composition } \\
\text { Outcomes }\end{array}$ \\
\hline $\begin{array}{l}\text { Curiosity-the desire to know more about } \\
\text { the world. } \\
\text { Curiosity is fostered when writers are } \\
\text { encouraged to } \\
\text { - use inquiry as a process to develop } \\
\text { questions relevant for authentic } \\
\text { audiences within a variety of } \\
\text { disciplines; } \\
\text { - seek relevant authoritative information } \\
\text { and recognize the meaning and value of } \\
\text { that information; } \\
\text { conduct research using methods for } \\
\text { investigating questions appropriate to } \\
\text { the discipline; and } \\
\text { communicate their findings in writing } \\
\text { to multiple audiences inside and outside } \\
\text { school using discipline-appropriate } \\
\text { conventions. }\end{array}$ & $\begin{array}{l}\text { - Analyze and interpret samples of good } \\
\text { writing, identifying and explaining an } \\
\text { author's use of rhetorical strategies and } \\
\text { techniques } \\
\text { - Apply effective strategies and } \\
\text { techniques in their own writing } \\
\text { - Create and sustain arguments based on } \\
\text { readings, research and/or personal } \\
\text { experience } \\
\text { - Write for a variety of purposes } \\
\text { - Produce expository, analytical and } \\
\text { argumentative compositions that } \\
\text { introduce a complex central idea and } \\
\text { develop it with appropriate evidence } \\
\text { drawn from primary and/or secondary } \\
\text { sources, cogent explanations and clear } \\
\text { transitions } \\
\text { Demonstrate understanding of the } \\
\text { conventions of citing primary and } \\
\text { secondary sources } \\
\text { Evaluate and incorporate reference } \\
\text { documents into researched papers }\end{array}$ \\
\hline
\end{tabular}


While the table draws attention to alignment between the criteria outlined for curiosity in the Framework and the outcomes for AP English Language and Composition, the ways in which curiosity makes its way into the classroom differs based on the individual course and the school, teacher, and students involved at a particular location. For example, students could demonstrate curiosity when they analyze writing completed by others, look into the practices that produce effective compositions, and use these models for their own compositions. Curiosity may also be seen as students question other texts and develop lines of inquiry. The ways in which curiosity is cultivated through AP English Language and Composition in Jefferson County Public Schools is further addressed in chapter four.

\section{Openness}

The Framework contends that students show openness when they realize how their individual perspective relates to the ways in which others see things. Students continue to demonstrate openness when they are open to and try new ways of questioning, researching, and sharing information. Moreover, openness becomes evident when students reflect on outside responses to their work. AP English Language and Composition is designed to create openness indirectly. While none of the twelve outcomes are directly tied to the criteria described for openness, there is an academic focus to the reading and writing completed in the course and, because of this, students should be expected to investigate multiple perspectives and examine how their line of inquiry fits into larger conversations on their topic of choice. While language tied to point of view and/or perspective is missing from the student learning outcomes, rhetorical devices, such as diction, tone, and purpose for example, lead students to examine perspective through the rhetorical situation. So, while the outcomes do not overtly 
address openness, it is embedded within other experiences provided by the course that are further addressed in chapter four.

Table 3: Openness \& AP English Language and Composition Outcomes

Openness - the willingness to consider new

ways of being and thinking in the world.

Openness is fostered when writers are

encouraged to

- examine their own perspective to find connections with the perspectives of others;

- practice different ways of gathering, investigating, developing, and presenting information; and

- listen to and reflect on the ideas and responses of others - both peers and instructors - to their writing.

\section{Engagement}

Students display engagement, according to the Framework, when they have a sense of awareness of how their ideas relate to others. They also show engagement when they experience growth and expand possibilities through new networks they have made and using what they have learned. Engagement is also encouraged through the learning outcomes for AP English Language and Composition and the table below shows alignment between the criteria for engagement presented in the Framework and the learning outcomes for AP English Language and Composition.

Table 4: Engagement \& \& AP English Language and Composition Outcomes

\begin{tabular}{|l|l|}
\hline $\begin{array}{l}\text { Engagement-a sense of investment and } \\
\text { involvement in learning. }\end{array}$ & $\begin{array}{l}\text { Analyze and interpret samples of good } \\
\text { Engagement is fostered when writers are } \\
\text { encouraged to }\end{array}$ \\
$\begin{array}{l}\text { author's use of rhetorical strategies and } \\
\text { techniques }\end{array}$ \\
$\begin{array}{l}\text { make connections between their own } \\
\text { ideas and those of others; }\end{array}$ & $\begin{array}{l}\text { Apply effective strategies and } \\
\text { techniques in their own writing } \\
\text { existing meanings as a result of new }\end{array}$ \\
\hline
\end{tabular}


connections; and

- act upon the new knowledge that they have discovered. experience

- Produce expository, analytical and argumentative compositions that introduce a complex central idea and develop it with appropriate evidence drawn from primary and/or secondary sources, cogent explanations and clear transitions

Even though the above table demonstrates alignment between the criteria for engagement and the outcomes for AP English Language and Composition, it is important to note that many different learning experiences have the potential to fall in this category. For example, when students are asked to engage in active reading and critical analysis they are engaged with texts. Engagement is also possibly demonstrated when students have an awareness of the ways in which their ideas relate to the ideas of others and how their initial ideas change as a result of these interactions. Specific literacy experiences included in various AP English Language and Composition courses that promote engagement are further discussed in chapter four.

\section{Creativity}

The Framework claims that students express creativity when they explore topics and subjects that are new to them and use unfamiliar research methods in this exploration. Students continue to display creativity when they express their findings in multiple ways and reflect back on how their choices impact their work, themselves, and others. The outcomes for AP English Language and Composition can be seen to encourage creativity in multiple ways, as demonstrated in the table below.

\section{Table 5: Creativity \& AP English Language and Composition Outcomes}

Creativity - the ability to use novel approaches for generating, investigating, and representing ideas.

Creativity is fostered when writers are
- Analyze and interpret samples of good writing, identifying and explaining an author's use of rhetorical strategies and techniques 
encouraged to

- take risks by exploring questions, topics, and ideas that are new to them;

- use methods that are new to them to investigate questions, topics and ideas;

- represent what they have learned in a variety of ways; and

- evaluate the effects or consequences of their creative choices.

- Apply effective strategies and techniques in their own writing

- Create and sustain arguments based on readings, research and/or personal experience

- Write for a variety of purposes

- Produce expository, analytical and argumentative compositions that introduce a complex central idea and develop it with appropriate evidence drawn from primary and/or secondary sources, cogent explanations and clear transitions

- Revise a work to make it suitable for a different audience

- Evaluate and incorporate reference documents into researched papers

Multiple opportunities exist for students in AP English Language and

Composition to cultivate and engage with creativity. For instance, students may be engaging in creativity when they are encouraged to explore topics and ideas that are new through reading and analyzing a variety of texts. Creativity may also be fostered as students are challenged to expand their lines of inquiry and ways of researching through obtaining information by broadening their horizons about the types of materials available and the function and purpose these materials may serve in their work. Moreover, creativity can also potentially be seen as students reflect on the ways in which their choices influence their work, themselves, and others. The ways creativity is encouraged through various literacy experiences is further explored in the next chapter.

\section{Persistence}

According to the Framework, students exhibit persistence when they work through the many stages of a challenging task through writing and finish projects that they start. They also demonstrate persistence when they use their time wisely and take advantage of opportunities for assistance and feedback. The following table shows how 
persistence is potentially fostered through AP English Language and Composition outcomes.

Table 6: Persistence \& AP English Language and Composition Outcomes

Persistence - the ability to sustain interest in and attention to short- and long-term projects.

Persistence is fostered when writers are encouraged to

- commit to exploring, in writing, a topic, idea, or demanding task;

- grapple with challenging ideas, texts, processes, or projects; and

- consistently take advantage of in-class (peer and instructor responses) and outof-class (writing or learning center support) opportunities to improve and refine their work.

Persistence can be demonstrated in various ways that are influenced by circumstances unique to particular locations. However, generally, students can be seen to persist when they work through challenging tasks through writing, such as the ones they are asked to complete in AP English Language and Composition. Persistence can also be seen as students revise compositions because revision often requires that students use their time wisely and continue to work with difficult projects as they take advantage of opportunities for assistance and feedback. While this brief comparison begins to show the ways in which the criteria for persistence are met by the outcomes of AP English Language and Composition, persistence is also connected to specific literacy experiences found in AP English Language and Composition and this is discussed more in chapter four.

\section{Responsibility}

The Framework explains that students reveal responsibility when they take ownership of their learning process. Students also show responsibility when they 
understand that they are entering and contributing to a conversation that is already in progress and cite when using ideas that are not their own. The following table depicts the AP English Language and Composition outcomes that have the potential to promote responsibility.

Table 7: Responsibility \& AP English Language and Composition Outcomes

\begin{tabular}{l|l}
\hline $\begin{array}{l}\text { Responsibility-the ability to take } \\
\text { ownership of one's actions and understand } \\
\text { the consequences of those actions for } \\
\text { oneself and others. }\end{array}$ & $\begin{array}{l}\text { Produce expository, analytical and } \\
\text { argumentative compositions that } \\
\text { Responsibility is fostered when writers are } \\
\text { encouraged to } \\
\text { - } \begin{array}{l}\text { recognize their own role in learning; } \\
\text { develop it with appropriate evidence } \\
\text { drawn from primary and/or secondary } \\
\text { sources, cogent explanations and clear } \\
\text { transitions }\end{array} \\
\begin{array}{l}\text { act on the understanding that learning is among the writer and others- } \\
\text { students, instructors, and the institution, } \\
\text { as well as those engaged in the } \\
\text { questions and/or fields in which the } \\
\text { writer is interested; and } \\
\text { engage and incorporate the ideas of } \\
\text { others, giving credit to those ideas by } \\
\text { using appropriate attribution. }\end{array}\end{array}$ \\
\hline
\end{tabular}

The above table depicts alignment between the criteria given for responsibility by the Framework and the outcomes for AP English Language and Composition. While alignment exists, the ways in which responsibility is demonstrated within classroom spaces varies. However, generally, students in AP English Language and Composition demonstrate responsibility when they take ownership of their own learning process through developing lines of inquiry, researching topics, and producing compositions to relate their findings. Moreover, students show responsibility when they interact in a mature manner with primary and secondary sources by showing an understanding that they are entering into and contributing to a conversation with others that is already in progress. Even though responsibility is seen in the outcomes for AP English Language 
and Composition, it is also seen in elements of the course that are not covered by the outcomes, such as when students act responsibly by preparing for class. These additionally literacy experiences that also foster responsibility are addressed in the following chapter.

\section{Flexibility}

Students demonstrate flexibility, according to the Framework, when they consider the rhetorical situation when deciding how to approach tasks. They continue to display flexibility when they utilize discipline specific conventions that are determined by context. The following table shows how the outcomes for AP English Language and Composition potentially align with the criteria for flexibility, as outlined by the

\section{Framework.}

Table 8: Flexibility \& AP English Language and Composition Outcomes

Flexibility - the ability to adapt to situations, expectations, or demands. Flexibility is fostered when writers are encouraged to

- approach writing assignments in multiple ways, depending on the task and the writer's purpose and audience;

- recognize that conventions (such as formal and informal rules of content, organization, style, evidence, citation, mechanics, usage, register, and dialect) are dependent on discipline and context; and

- reflect on the choices they make in light of context, purpose, and audience.

Flexibility is shown when students consider the rhetorical situation, including using discipline specific conventions, to plan their writing tasks. They also demonstrate flexibility when they reflect on the choices that they have made in response to the situation for which they are composing. While these things show flexibility, flexibility is
- Apply effective strategies and techniques in their own writing

- Write for a variety of purposes

- Write thoughtfully about their own process of composition 
also encouraged through specific literacy experiences that will be further addressed in the next chapter.

\section{Metacognition}

According to the Framework, students demonstrate metacognition when they are aware of and reflect on the ways in which they think and write in context for multiple audiences. They also demonstrate metacognition when they realize the relationship between the various elements of the rhetorical situation. Likewise, metacognition is shown when students reflect on their completed work and use reflections to improve future work. Students enrolled in AP English Language and Composition reflect on their learning through two of the outcomes, as demonstrated by the table below.

Table 9: Metacognition \& AP English Language and Composition Outcomes

\begin{tabular}{|c|c|}
\hline $\begin{array}{l}\text { Metacognition-the ability to reflect on } \\
\text { one's own thinking as well as on the } \\
\text { individual and cultural processes and } \\
\text { systems used to structure knowledge. } \\
\text { Metacognition is fostered when writers are } \\
\text { encouraged to } \\
\text { - examine processes they use to think and } \\
\text { write in a variety of disciplines and } \\
\text { contexts; } \\
\text { - reflect on the texts that they have } \\
\text { produced in a variety of contexts; } \\
\text { connect choices they have made in texts } \\
\text { to audiences and purposes for which } \\
\text { texts are intended; and } \\
\text { use what they learn from reflections on } \\
\text { one writing project to improve writing } \\
\text { on subsequent projects. }\end{array}$ & $\begin{array}{l}\text { - Write thoughtfully about their own } \\
\text { process of composition } \\
\text { - Revise a work to make it suitable for a } \\
\text { different audience }\end{array}$ \\
\hline
\end{tabular}

The exact ways in which these types of reflection activities enter AP English Language and Composition depends greatly upon the individual teacher and structure of the course. However, the outcomes do foster metacognition, even though the degree to which this is promoted depends heavily on the individual course. 
The above analysis considers the ways in which the official course outcomes for AP English Language and Composition intersect with the Framework by examining alignment between the eight habits of mind and the outcomes. However, it is also important to see how these dispositions are picked up by and carried out by actual AP English Language and Composition teachers. Therefore, in the next chapter I turn to examining the dispositions and skills that are promoted in AP English Language and Composition courses in Jefferson County Public Schools in Kentucky to identify common literacy experiences that are being fostered and the ways in which these experiences promote college readiness as it is identified in the Framework.

\section{Conclusions}

While the outcomes for AP Language and Composition focus on skills that are directly relatable to first-year composition, the eight habits included in the Framework allow the conversation to focus on dispositions that are important for students to develop because of their connection to success. The Framework provides another way to look at college readiness that moves the conversation away from standardized assessments and towards a focus on student development and learning. The conversation shifts as more and more students are enrolling in AP courses for the rigorous curriculum and not necessarily for the potential college credit. And, the dispositions fostered in AP English Language and Composition become even more important as the demographics of students enrolled in AP courses changes because students will meet the outcomes to varying degrees. Thus, the outcomes, while important, do not ensure sufficient college preparation, especially for students scoring below a 3 on the exam or in programs such as Advance Kentucky. However, a curriculum that promotes certain dispositions, just as I 
show AP English Language and Composition does, would offer sufficient preparation for students to begin to develop dispositions associated with success. In short, I argue that the habits promoted in the Framework are fostered in AP English Language and Composition and encourage dispositions that will not only help students in reaching the outcomes for the course but also prepare them to enter postsecondary institutions ready to succeed.

This chapter has considered where the eight habits originated and the ways in which the official outcomes for AP English Language and Composition intersect with the criteria outlined for these dispositions. However, it is also important to see how the course is picked up by and carried out by actual AP English Language and Composition teachers. Therefore, in chapter four, I turn to exploring the various literacy experiences found in several AP English Language and Composition courses across Jefferson County Public Schools and the ways in which these experiences promote the cultivation of dispositions found in the Framework through the incorporation of the outcomes for AP English Language and Composition. In short, the College Board is promoting specific types of literacy experiences in AP English Language and Composition that purposefully align with literacy experiences promoted in first-year writing courses. Based on the alignment of criteria associated with individual dispositions with outcomes for the course, the implicit assumption exists that the dispositions described in the eight habits of mind in the Framework are also encouraged in AP English Language and Composition instructional practices. However, the dispositions cultivated in AP English Language and Composition literacy experiences have not yet been examined. I begin this investigation in the following chapter. 


\section{CHAPTER 4: CULTIVATING DISPOSITIONS THROUGH LITERACY EXPERIENCES: AP ENGLISH LANGUAGE AND COMPOSITION AND COLLEGE READINESS}

"My goal is to not only help my students in terms of skills—critical reading skills, research skills, writing skills, and writing in terms of research writing, argumentative writing, rhetorical analysis writing — but I am also really pushing habits that they have, that they form as a junior in high school, so that when they are in college they are going to have the stick-with-itness, the motivations, the discipline to be able to yes not just take the freshmen level classes that are easy but be able to be very successful in those upper level classes and some of them are even successful as freshmen and get to take those upper level classes.” (Interview 13 March 2014)

$\sim$ Stella

The opening quotation by Stella, an AP English Language and Composition teacher at Violet Fields High School, highlights the goals that provide the foundation for the learning experiences she offers students. While she greatly hopes that students in her class will develop and mature in their writing skills, she also stresses that students also cultivate and form habits that assist them in being successful in college.

\section{Literacy Experiences in AP English Language and Composition}

While the previous chapter examines how policy documents produced by the College Board for AP English Language and Composition overlap with dispositions that 
have been shown to increase college readiness, this chapter focuses on the ways in which these policy documents play out in individual classrooms to foster different types of literacy experiences. This is important to consider because how individual teachers pick up and carry out the outcomes is influenced by their individual history, experiences, teaching philosophy, and thoughts on college readiness. The following analysis is based on syllabi ${ }^{29}$ collected from four AP English Language and Composition teachers in Jefferson County Public Schools during the 2013-2014 academic year. All four teachers agreed to participate in this research project and graciously shared their AP English Language and Composition resources with me. In this chapter, I focus on the ways in which individual teachers adopted and adapted the official course description for AP English Language and Composition to reflect their individual perspective and course design. I then investigate the ways in which the outcomes included on individual syllabi reflect the eight habits discussed in chapter three.

The course description provided by the College Board encourages teachers of AP English Language and Composition to individualize the course and emphasizes that the course is based on skills and not content. As the Teacher's Guide points out, “[b]ecause both the AP English Language and Composition and English Literature and Composition Exams are skills-based as opposed to content-based, teachers have tremendous latitude in designing their classes" (xii). Therefore, teachers can use a variety of methods and a wide range of texts to teach the skills covered by the outcomes. This individualization becomes apparent when looking at the similarities and differences in how different teachers

\footnotetext{
${ }^{29}$ Selections from syllabi discussed in this chapter can be found in the appendix. Supplements, such as handouts, assignment sheets, and scanned documents from other sources are not included, even though some teachers include this material with the syllabus.
} 
describe the AP English Language and Composition course based on their approach and experience.

However, because all AP English Language and Composition courses must be approved through the audit process to ensure that secondary courses assigned the AP label offer the rigor and challenging curriculum prescribed by the College Board, many of the syllabi for the course share similar traits. The Teacher's Guide explains,

College Board member schools at both the secondary and college levels requested an annual AP Course Audit in order to provide teachers and administrators with clear guidelines on curricular and resource requirements that must be in place for AP courses and to help colleges and universities better interpret secondary school courses marked 'AP' on students' transcripts" (xi).

Additionally, "[ $t$ ]he AP Course Audit form identifies common, essential elements of effective college courses, including subject matter and classroom resources...Schools and individual teachers will continue to develop their own curricula for AP courses they offer-the AP Course Audit will simply ask them to indicate inclusion of these elements in their AP syllabi or describe how their courses nonetheless deliver college-level course content" (xi). In short, the course audit is a measure taken by the College Board to ensure quality control of AP courses while still allowing teachers to individualize courses based on personal experiences and the available resources at particular locations. Yet, this process has the potential to be problematic because the College Board is only auditing a paper document and provides no oversight as to what is actually occurring at the classroom level. Therefore, the possibility exists that teachers, while having a syllabus 
that passes the audit system, are teaching the course radically different from the intentions of the College Board.

\section{AP English Language and Composition: An Investigation of Four Courses Course Descriptions and Outcomes}

\section{Stella at Violet Fields High School}

Stella teaches AP English Language and Composition at Violet Fields High School $^{30}$. Stella's course description is very extensive and covers a single page of singlespaced text. She emphasizes six different elements when describing her AP English Language and Composition course. The first aspect of the course Stella emphasizes is that "AP English Language and Composition corresponds to the college composition course; therefore, it is an advanced writing course that includes the study of rhetoric and argument" (1). With this portion of the description, she also explains that the course will focus on nonfiction texts and students will be expected to compose in a variety of different modes. The second aspect of the course emphasized focuses on the interconnectedness between reading and writing. She explains that students will be required "to read complex texts with understanding and to write prose of sufficient richness and complexity to communicate effectively with mature readers" (1). In the third aspect, Stella describes the type of student that the course is designed for when she explains that "[s]ince teacher recommendation is a requirement for this course, an assumption is made that students have already developed a command of Standard English grammar and mechanics" (1). Moreover, students should also demonstrate the "ability to think abstractly, interpret, and read beyond the surface or for mere plot summary are keys to success" (1). The fourth element details the type of feedback the student can expect

\footnotetext{
${ }^{30}$ See chapter two for a more complete description of Violet Fields High School.
} 
from the teacher during the course. This includes vocabulary usage, sentence structure, organization, use of detail, and use of rhetorical devices. The fifth element plainly states, without description, that "skills, knowledge, habits, stamina, endurance, selfassessment, reflection" will be "emphasized in this course in order to prepare students for college" (bold original 1). The sixth element details how the course is taught in conjunction with the $11^{\text {th }}$ grade district curriculum and therefore will focus on "American Literature, in addition to nonfiction, by reading several novels and other minor pieces of creative writing" (1).

\section{Sophia at Green Gables High School}

Sophia teaches AP English Language and Composition at Green Gables High School $^{31}$. The school is taking part in Advance Kentucky, described in chapter one, to increase enrollment of nontraditional students in AP courses. Sophia's course description is very different from Stella's. Sophia provides a succinct five-sentence description. She describes the course by saying that "[t]his course is an English course, a college-prep course, and a preparatory course for the College Board's Advanced Placement Exam in English Language and Composition" (1). She continues to remind students that they must take the AP exam, if they remain in the course. She ends her description by touching briefly on the skills that students will practice. She breaks this into two elements. First, she explains that they will be studying literature that "will build on analytical skills you have been developing throughout high school" (1). She then explains that "[t]he language and writing component of the course trains you to analyze prose style and rhetoric" and write effectively in a variety of different genres.

\footnotetext{
${ }^{31}$ See chapter two for a more complete description of Green Gables High School.
} 


\section{Henry at Orange Tree High School}

Henry teaches AP English Language and Composition at Orange Tree High School $^{32}$. Similar to Sophia's description, Henry focuses the course in two brief paragraphs. In these two paragraphs he explains that AP English Language and Composition will "offer a broad writing experience to allow students to sharpen their analytical and rhetorical skills" (1). He continues to explain that his "course will focus on the art and analysis of argument, and how to apply rhetorical skills in future careers" (1). He ends by stating that the course will prepare students to take the AP English Language and Composition exam.

\section{Owen at Red River High School}

Owen teaches AP English Language and Composition at Red River High School $^{33}$. He also provides a concise description of what to expect in his AP English Language and Composition course. His description covers four main points. First, he explains that " $[\mathrm{t}]$ his course engages students in becoming skilled readers of prose written in a variety of periods, disciplines, and rhetorical contexts and in becoming skilled writers who compose for a variety of purposes and audience" (1). He continues to explain that the examination of effective writing will be a key component of the course. His syllabus states that "[b]oth their writing and their reading should make students aware of the interactions among writer's purpose, audience expectations, and subjects as well as how the generic conventions and the resources of language contribute to effectiveness in writing" (1). He goes on to explain that "the class discussion will focus on the author's technique, meaning, and expression of philosophical ideas" (1). Finally, similar to Stella,

\footnotetext{
${ }^{32}$ See chapter two for a more complete description of Orange Tree High School.

${ }^{33}$ See chapter two for a more complete description of Red River High School.
} 
Owen stresses that this course is "similar to an introductory college writing course that focuses on exposition, argument, and literary analysis" (1).

Although course descriptions, outcomes, and goals reveal clues as to how individual teachers promote literacy through AP English Language and Composition, the ways in which the teachers adopt and adapt the outcomes also provides information concerning the skills and dispositions being fostered. It is important to keep in mind that even though differences exist between the AP English Language and Composition courses in this study, all teachers base the course on the materials produced and endorsed by the College Board that where examined in chapter three. Now, I turn to examining how the outcomes included in Stella's, Sophia's, Henry's and Owen's syllabi work with the outcomes produced by the College Board to encourage literacy experiences that promote college readiness. As demonstrated by the differences in course documents, these four courses encourage literacy experiences in slightly different ways, even though they are created from the same official course documents produced by the College Board for AP English Language and Composition. Yet, these differences are slight and most commonly arise because of differences in student population, school histories, teacher history, and material resources. The following analysis indicates that there are several consistent experiences being fostered in AP English Language and Composition courses participating in this project. Although there is slippage and problems arise, the goal of this section is to use textual documents and information gained from teacher interviews to examine the ways in which teachers interpret and use official documents to enact individual AP English Language and Composition courses. 
Stella adopts the outcomes from the College Board word for word. Owen also adopts the language of the learning outcomes produced by the College Board but he adds three learning outcomes to his course. At the end of his course students should also be able to "[a]nalyze the historical and cultural development of American literature with insight and clarity", which reflects the outcomes mandated by the district for $11^{\text {th }}$ grade. Students will also "[w]rite under time constraints" because not only will they have limited time to compose responses to the essay portion of the AP English Language and Composition exam but they will also be sitting for the on-demand writing assessment that all $11^{\text {th }}$ grade students in the state of Kentucky take. Lastly, Owen's students will "[r]ead and analyze a minimum of six longer works of fiction in addition to the required summer reading" (1).

Unlike Stella and Owen, Sophia takes the twelve outcomes published by the College Board and makes them her own by re-writing and condensing them. Sophia's students can expect to: "[w]rite in several forms... about a variety of subjects;" utilize the writing process; reflect on their work through journaling; "[c]omplete expository, analytical, and argumentative writing assignments that are based on readings representing a wide variety of prose styles and genres;" "[a]nalyze a variety of fiction and nonfiction readings" for rhetorical strategies; "[a]nalyze how graphics and visual images both relate to written texts and serve as alternative forms of texts;" research and cite according to appropriate conventions; and "cite sources" (1). While Sophia's outcomes still align with the outcomes stated by the College Board, the wording is more approachable and provides a concrete idea of what students will actually be doing in the course. Sophia's approach to presenting a condensed version of the outcomes may be influenced by the 
student population that Green Gables High School serves. Many students in Sophia's class would typically be excluded from AP coursework and the possibility exists that stating the outcomes as constructed by the College Board would prove to be overwhelming for students. In short, Sophia's abbreviated version works to rely the purpose of the course in simplified terms to students needing extra support, both with developing academic skills and developing confidence.

Similar to Sophia, Henry greatly alters the outcomes for his AP English Language and Composition course. He condenses the outcomes into four extremely concise statements. His students can expect to "examine the nature and history of the English essay;" "read broadly among a variety of authors, rhetorical purposes and eras;" "engage in a significant study of writing as art;" and "learn to employ the fundamentals of sound argumentation" (1). While Henry also condenses the outcomes, his approach seems to be more the result of blending the AP English Language and Composition outcomes with other outcomes that his course meets through incorporating state and district standards and presenting students with a reasonable number of outcomes for the course. Even though there are fewer outcomes, Henry has combined ideas from multiple outcomes and continues to cover the content described by the College Board.

Literacy experiences are shaped by the ways teachers adopt and adapt the foundational framing documents. The course description for individual teachers reveals the experiences that particular courses are designed to foster and provide clues to the background and goals of the student population. While course syllabi provide some details about what is occurring in AP English Language and Composition, a more accurate and detailed picture of the learning experiences emerge through examining 
informal and formal writing assignments and through conversations with teachers about how they interpret the purpose of the course and how they see the course preparing students for college, either as a precollege credit for writing option or as a course to promote college readiness so that a student is ready to enter first-year composition when they enter their chosen postsecondary institution.

While the teachers participating in this study all heavily rely on the outcomes produced by the College Board, they make adjustments as necessary to better relate to the students they are serving. Despite these differences, the skills and dispositions fostered by these teachers remain consistent, even though not all students are ready to approach the skills and dispositions at the same level. In short, the differences in course descriptions discussed above possibly indicates the ways in which individual teachers enact AP English Language and Composition based on their history, expectations of individual schools, and resources available in order to best serve the student population and their future goals.

\section{Writing}

\section{Assignments}

Stella's students at Violet Fields High School begin their AP English Language and Composition course the summer before they enroll and complete the first formal writing assignment before any instruction has occurred. For this independent assignment, Stella asks her students to either read Outliers by Malcolm Gladwell or Lies My Teacher Told Me by James W. Loewen and "write an essay in which you define one of the central arguments of the book and analyze the rhetorical strategies that...[the author] uses to construct his argument" (12). This assignment is "used as a diagnostic tool" (12). During the school year, students also use critical reading skills to investigate an editorial about a 
current event every other week. In addition to the ongoing editorial project, students complete book reviews where they introduce a book, summarize the main points, and evaluate how well rhetorical devices are used. Students in Stella's class also visit Ekstrom Library at the University of Louisville to complete a research project. In short, Stella's students are completing a variety of challenging writing assignments that work to cultivate the skills addressed in the outcomes and promote dispositions linked with success.

Sophia's students at Green Gables High School write one formal paper per unit, which equals six assignments throughout the year. Students are performing much less formal writing in Sophia's class than they are in Stella's class. However, the population of students that Sophia serves includes many students that would traditionally be excluded from AP courses. Even though the amount of formal writing that Sophia's students complete is less than at other schools, they do complete a variety of informal writing assignments. These informal assignments include responding to texts discussed during class and completing items released by the College Board as practice for the AP English Language and Composition exam. While Sophia's students do not compose as frequently or in response to the challenging tasks that are seen in Stella's course, Sophia's students have not yet developed the skills and dispositions that allow them to work intensely outside of class. The students at Green Gables High School are at a lower developmental level, as indicated by the large number of students missing college readiness benchmarks in English and Reading by several points, and need more guidance through scaffolded writing instruction. These students also need more support and direction from Sophia and the course moves at a slower pace as a result. 
Henry's students at Orange Tree High School compose a variety of formal and informal compositions. Students compose a personal essay, persuasive speech, rhetorical analysis, compare/contrast essay, synthesis paper, and issue based research paper. The expectation is that students will work through the various stages of the writing process and receive feedback from peers during peer response activities and from Henry during individual conferences. In addition to these formal assignments, students in Henry's class also compose daily informal writing assignments where they respond to texts. Some of these responses take the form of dialectical journals. Henry's students are composing frequently to a variety of rhetorical situations that mimic the writing required on the AP English Language and Composition exam and genres commonly found in first-year writing courses.

Owen's students at Red River High School also compose multiple assignments, both formal and informal. Owen's students can expect to complete a literary analysis, editorial, personal essay, rhetorical analysis, analytical essay, synthesis essay, definition essay, satire essay, rhetorical analysis on style, compare/contrast essay, and a final writing project. These eleven writing projects undergo peer revision, discussed during student-teacher conferences, and revised based on all comments. Not only do Owen's students complete these formal writing projects, they also complete a variety of informal writing assignments that ask them to respond critically to readings, to practice composing released prompts from past AP English Language and Composition exams, and to experiment with rhetorical elements of their own writing ${ }^{34}$. In short, students at Red River High School are frequently composing in response to a variety of rhetorical situations where they combine critical reading and writing skills to compose assignments

\footnotetext{
${ }^{34}$ The assignments included in Owen's class will be looked at in more detail in chapter seven.
} 
that prepare them for the AP English Language and Composition exam and postsecondary writing experiences.

\section{Writing Process}

Despite the portfolio system being abandoned in the state of Kentucky and less emphasis on the writing process as a result, all teachers participating in this project encourage students to engage in the writing process. While Stella's syllabus hints at the role that the writing process plays within her course, she speaks explicitly about it during our interview. Stella explains that once the assignment is explained and students have read professional models that they "talk about pre-writing in terms of all right here's the assignment. What are some of your ideas right now? Where are you going to go" (Interview 13 March 2014)? Stella's students complete drafting outside of class. After drafting, Stella explains that students engage in some type of peer workshop. Stella uses a variety of peer response techniques but in all of her approaches she continues to follow the ethics of portfolio conferencing that the state of Kentucky required when the portfolio assessment system was in place. Stella explains that the ethics of portfolio conferencing says no conferencing partnerteacher, peer, parent, outside workshopper—can change a student's writing. You cannot correct something for them. You cannot tell them how to fix something...You can ask questions of the text. So, that limits us just a little in terms of what they can write but they are instructed to write comments as they go through and at the very end they're supposed to give some praise and some constructive criticism. (Interview 13 March 2014) 
Additionally, Stella strongly encourages students to conference with her on drafts. These conferences usually take place afterschool and it is the student's responsibility to seek out a conference. In short, the writing process plays a key role in the composing process of Stella's students and works to foster dispositions, such as responsibility and persistence.

Similar to Stella, Sophia expects students to actively engage with the writing process in her course and describes the various stages of the writing process on her syllabus. Moreover, Sophia explains the pre-writing process for her course: "I call it my down and dirty outline. Where they should have a thesis statement, three topic sentences for their body, and, ideally, have one piece of evidence that they'll use in each of those body paragraphs" (Interview 11 March 2014). The writing process for Sophia's students is very prescriptive and teacher directed. However, this allows students the structure and support that they need in order to compose. Additionally, Sophia explains "we really start small" and the students need guidance. Sophia even goes as far as to have students separate claims, evidence, and analysis and identify each with a different color highlighter to help them visualize what aspects are present in their writing. Although Sophia is more directive in how students engage with the writing process, students at Green Gables High School are developing an awareness of the recursive process of writing.

Similar to Sophia, Henry is very specific in the role the writing process plays in his course. In his syllabus, he explains that "[e]ach paper will proceed through multiple drafts. We will use teacher conferences and peer response groups where students will help each other brainstorm, revise, edit and polish their papers" (2). Furthermore, Henry explains that students need to understand that they cannot write the paper the night before 
it is due and ignore prewriting and revision. He explains, "[i]n high school, as good of writers as I have, they still need instruction. They still need the... process [topic selection, brainstorming, drafting, more brainstorming, revision]... So I've got to at least train them for that...so that when they are turned loose they will know how to" go about composing a paper and realize that they need the process. In short, Henry sees incorporating the writing process as directly preparing students for a variety of postsecondary writing experiences.

Owen also stresses the writing process in his AP English Language and Composition course. He is more directive than Stella but does not provide the strict guidelines that Sophia does for her students. Owen describes the place of the writing process in his syllabus. He says, "a great deal of time will be spent on prewriting, editing, and revision (with multiple opportunities for revision afforded to include teacher review, counseling and commentary as well as peer review)" (2). Furthermore, Owen breaks apart what he sees as important processes for each stage. He explains that "First drafts will be peer reviewed under strict guidelines provided by the teacher" (2). Students can then expect that "[s]econd drafts will be reworked in workshops...[and] [t]hird drafts will be revised and edited through teacher conferencing to finalize edits and discuss effect and voice" (2). Owen, similar to Sophia, is very directive in the ways in which students will engage in the writing process. The direct approach may be the result of the variety of students that are enrolled in AP English Language and Composition at Red River High School and the need to train students how to give useful critical feedback.

Although encouraging students to engage in the writing process fosters important work, how this is being carried out in some instances raises concern and creates tension 
with the AP English Language and Composition outcomes and with the habits of mind encouraged in the Framework. For example, Sophia approaches the writing process in somewhat rigid ways that neglect to acknowledge the recursive nature and messiness often associated with writing. Sophia's control and directness with the writing process does contradict the goals and purpose outlined in the AP English Language and Composition outcomes, especially when considering whether or not the students are achieving competency in meeting the outcome that calls for them to "move effectively through the stages of the writing process, with careful attention to inquiry and research, drafting, revising, editing and review" (AP English Language and Composition Outcomes). Additionally, this prescriptive approach runs contrary to the creativity, openness, and flexibility promoted in the Framework. However, the need for Sophia to exert this type of control most likely stems from the population of students that she is working with and the resources available to her at her school. Because many of Sophia's students would place into developmental writing courses at the postsecondary level, with sub scores as low as 12 on ACT Reading and English, they not only need to develop writing skills and dispositions for success but they also need to develop confidence. Templates, models, and teacher directed process seems to be needed because the students, while enrolled in an AP class, are in need of remediation. In short, in order for Sophia to move students' writing development along, she must offer them specific supports, with the hope that as they develop as writers and gain the habits of mind associated with college readiness, they will be successful in first-year college writing at postsecondary institutions. Sophia is working with a group of students that were never intended to be served by the AP program. Thus, as AP courses, such as AP English 
Language and Composition, are being used in innovative ways to increase college readiness conflicts, such as this one, will arise and teachers, similar to Sophia, must work within the constraints to prepare students for postsecondary education.

\section{Synthesis and Research}

Through the exam, AP English Language and Composition attempts to foster synthesis skills. The source material is provided for students in the exam prompt when they are asked to synthesize. Synthesis skills are necessary in order for students to be successful in answering one of the essay questions on the AP English Language and Composition exam. Despite the fact that in postsecondary writing courses synthesizing source material is typically tied to locating and evaluating source material, the type of synthesis required on the AP English Language and Composition exam divorces the research process and synthesis process. Although students are still being asked to evaluate the material being synthesizing, because they have the choice over which material included in the prompt to use and how to use it in their response, the synthesis that students demonstrate on the exam is completely separated from the research process.

Even though the AP English Language and Composition exam does not connect synthesis and research, some teachers do promote synthesis in relation to effective research practices and move past the superficial synthesis of pre-selected materials that students are asked to complete on the AP English Language and Composition exam. Stella, for example, assigns her students a semester long research project that requires them to develop a topic of interest, conduct authentic research using a variety of scholarly and popular sources, write an argumentative paper around 10 double-spaced pages, and write and deliver a persuasive speech on their chosen research topic. Henry's students complete a similar assignment where students will compose "an issue-based research 
paper where... [they] will select an important cultural, political, or social issue and formulate a thesis based upon research" (2). Students are asked to complete true synthesis in this project and use "at least seven primary and secondary sources" (2). Thus, even though the level at which synthesis is being sponsored varies, students are gaining the valuable skill of using multiple sources to support an argument that they craft. In the best circumstances, AP English Language and Composition teachers are extending synthesis skills beyond what is necessary for students to do well on the AP English Language and Composition exam and allowing students practice with important skills that they will utilize in completing writing assignments for postsecondary courses.

\section{Reading}

Reading is also an essential element of AP English Language and Composition and participating teachers stress that teaching students to read critically is challenging but vital. Because reading is so important, students spend a great deal of time reading and responding to a variety of texts. Yet, what this means at individual locations varies. However, what remains consistent is that students are working with both fiction and nonfiction texts. The Course Description stresses that, while there is no set reading list, students must interact with nonfiction texts. Through the emphasis on nonfiction texts students are being encouraged to read a variety of texts that encompass multiple themes, issues, and contexts. The framing documents are clearly encouraging literacy so as to separate and differentiate between literature and nonfiction prose with a heavier emphasis on the latter.

While the primary text used by Stella's students at Violet Fields High School is The Informed Argument, $7^{\text {th }}$ Edition by Robert K. Miller, Stella's great use of supplemental material ensures that the students are exposed to a variety of high level 
texts. For example, Stella supplements with readings from Classical Rhetoric for the Modern Student, Prentice Hall Literature: The American Experience, Elements of Writing, Fifth Canon, The Norton Reader, Picturing Texts, 50 Essays: A Portable Anthology, Everything's An Argument, Ways of Reading $4^{\text {th }}$ edition, and many other texts such as Paulo Fierre and bell hooks. This is in addition to any literature that the students read for the course. Thus, students coming from Stella's class are being exposed to a wide range of text that are commonly used in the teaching of first-year writing. However, Stella is dealing with the top students in the district and this allows her to design the course using very challenging reading material.

Sophia's students at Green Gables High School also read a variety of texts but the level at which students investigate these texts differs greatly from Stella's students. Sophia openly discusses the difficulties of teaching AP English Language and Composition at one of the lowest performing schools in the district. She explains, "So, I would say out of the whole junior class, we had maybe, on the last practice test, I think $25 \%$ hit the Kentucky benchmark for English and reading. So, we are not starting with Jonathan Swift. We are reading Johnathan Swift now [in March] and they are still struggling with it" (Interview 11 March 2014). While Sophia also includes selections from other texts, such as 40 Model Essays, A Portable Anthology, The Bedford Reader, and Everything's An Argument, she mainly uses The Language of Composition and spends a great deal of time assisting her students in strategies to aid comprehension. As she explains, "I kind of use a mixture. I probably use The Language of Composition a little bit more. It just has great essays and follow-up questions...the questions are doing exactly what I need them to be doing, and it walks them through" the text (Interview 11 
March 2014). Thus, even though students are being exposed to some of the same texts as Stella's students, what the students are being asked to do with those texts differ.

A limited fund for purchasing confines Henry's students at Orange Tree High School to fewer texts. Henry relies on three main texts for readings. These are 100 Great Essays, $4^{\text {th }}$ edition by Robert DiYanni, $A$ Writer's Resource by Elaine P. Maimon and The Language of Composition, $1^{\text {st }}$ edition by Renee H. Shea et al. This core is supplemented by novels. As Henry explains, he would like to use additional texts but the resources permitted at his school do not allow for additional purchases. In fact, he is often forced to use a class set of texts which means that students cannot complete readings outside the classroom space. As he explains, "I use The Language of Composition $1^{\text {st }}$ edition. I would love to [have the new edition] and I only have a class set. We [at Orange Tree High School] have $\$ 40,000$ in textbook funds this year and I can’t even get a class set of [Everything's An Argument]" (Interview 10 March 2014). Even though Henry would like additional resources, the texts read by students at Orange Tree High School are challenging and allow students to practice the critical skills called for in the course.

Reading is also a core part of Owen's course at Red River High School. In addition to outside novels, his students rely on five core texts: The Language of Composition, Everyday Use: Rhetoric at Work in Reading and Writing, The Norton Reader: $11^{\text {th }}$ Edition, Literature: Reading, Fiction, Poetry, Drama, and Write for College. Similar to Sophia, Owen explains that he spends a great deal of time the first twelve weeks of school modeling reading strategies and teaching his students to read for comprehension because of the open enrollment policy that Red River High School follows for AP courses, as part of its participation in Advance Kentucky. As his course 
sequence illustrates, he spends multiple days reading short pieces with his students in the beginning of the school year. For example, students spend five days during the second week of school reading Francine Prose's "I Know Why the Caged Bird Cannot Read", a short essay of about 10 pages that originally appeared in Harper's Magazine in 1999. They then spend four days reading James Baldwin's “A Talk to Teachers. He explains that "[t]he majority of the first twelve weeks revolves around teaching students how to read critically and ascertain the effective uses of rhetoric" (Interview 24 March 2014). After the first trimester, the pace picks up as the class moves from comprehension to analysis and Owen "start[s] to transition the course away from strict textual analysis and move more toward writing instruction" (Interview 24 March 2014). In short, Owen seems very deliberate in the way in which reading is approached in AP English Language and Composition at Red River High School in order to support the development of critical reading skills and foster comprehension strategies.

In locations that encourage open enrollment for AP courses and seek to enroll students who may not be as qualified to take the course, teachers spend additional course time on reading and comprehension strategies. Sophia and Owen both discuss the fact that many students enrolled in their AP English Language and Composition courses are not prepared to handle the level of complexity present in the required readings. Sophia shares that she usually begins with basic comprehension. She explains that "half of the time, especially in the complex texts, in order to do any of the more analytical things, I need to know they actually understand what the heck this guy is saying" (11 March 2014). Likewise, Owen explains that he spends the first twelve weeks focusing on teaching the students how to read the texts and strategies for reading. As mentioned 
above, the first several reading assignments are intricately scaffolded so that students learn to read for pertinent information on their own and focus on the author's use of rhetoric and style.

While the focus on reading and reading comprehension is not commonly found to this degree in AP English Language and Composition, it does not seem to interfere with the course outcomes as designed by the College Board or to alter the shape of the course in drastic ways. As the Teacher's Guide explains, "'[b]ecasue... the AP English Language and Composition... exam...[is] skills-based as opposed to content-based, teachers have tremendous latitude in designing their classes...the course prescribes no core curriculum, no list of required titles, and no particular chapters to cover" (xii). Therefore, the focus on reading and reading comprehension at these particular locations does not seem to interfere with the outcomes because these are foundational skills that students must acquire before they are able to master the outcomes. Whereas the Framework ultimately pushes students towards independent and self-regulated learning, this practice of focusing on reading and reading comprehension in such directed ways may appear contradictory. However, the Framework describes the habits of mind that college ready students demonstrate before entering postsecondary education. The students enrolled in AP English Language and Composition are mostly eleventh grade students and have an additional year to work on cultivating these dispositions before they enter postsecondary education. Additionally, and even more important to consider, the students that Sophia and Owen are working with, for the most part, are not college ready according to benchmark scores on standardized assessments. Consequently, these students who would typically be excluded from AP English Language and Composition 
based on standardized assessment scores are in need of additional modeling so that they can develop important skills, such as reading comprehension strategies, that will allow them to be successful in postsecondary education. Moreover, several scholars in Rhetoric and Composition argue for the importance of reading instruction in first-year writing courses (Adler-Kassner \& Estrem; Keller; Jolliffe; Salvatori \& Donahue; Sommers). Thus, the focus on reading in AP English Language and Composition can be seen to align with practices advocated for in first-year writing courses.

\section{American Literature}

The AP English Language and Composition courses in this study also promote knowledge and awareness of the American literary tradition because American Literature is the focus of district curriculum for eleventh grade students. As Stella explains, "[t]his AP course at [Violet Fields High School] is taught to juniors as part of the regular English curriculum. The focus of junior year is American Literature with an emphasis on literary movements and authors, therefore, students will experience American Literature, in addition to nonfiction, by reading several novels and other minor pieces of creative writing" (1). Because Stella and the other participating teachers follow district mandated curriculum, the inclusion of American Literature is a common feature for AP English Language and Composition courses in Jefferson County Public Schools. As Owen comments in his syllabus, students are expected to "[a]nalyze the historical and cultural development of American Literature with insight and clarity" (1) and the major texts he includes focus on key pieces of American Literature. Henry's course also includes texts key to the American literary tradition. His students will read texts that "revolve around the American Abolitionist movement" (3), examine the workings of civil disobedience using Henry David Thoreau's Civil Disobedience and read texts focused on the American 
Dream. As Henry explains, "[m]any works of American literature revolve around the attainment or denial of this promise" (4). Therefore, Henry's students will explore work by Walt Whitman, F. Scott Fitzgerald and writers associated with the Harlem Renaissance. American Literature also plays a prominent role in Sophia's syllabus. However, she does not stress its appearance in the course but American Literature texts are included on the syllabus.

While the focus on American Literature can be traced to district requirements for $11^{\text {th }}$ grade English, its place in relation to the teaching of writing and the AP English Language and Composition course is less clear. However, this literary tradition does offer a wide variety of nonfiction texts that may be incorporated into the course and align with the College Board's goals for the course. Additionally, the inclusion of American Literature does not contradict the outcomes because two of the outcomes call for students to "analyze and interpret samples of good writing identifying and explaining an author's use of rhetorical strategies and techniques" and to "create and sustain arguments based on readings, research and/or personal experience" (AP English Language and Composition Outcomes). It does not matter so much what the students read but that they are reading and analyzing texts rhetorically. The Teacher's Guide even stresses that there are multiple readings that can lead students to develop competency in the outcomes. In short, AP English Language and Composition is designed in such a way that the focus is more centered on what students are doing with the texts rather than on the texts themselves.

However, the focus on American Literature may become problematic if the emphasis shifts too heavily to the type of literature under discussion and away from writing. This shift could potentially cause the course to become a humanities based 
literature class, rather than the rhetoric and writing course outlined by the College Board. Because teachers are attempting to merge state and district requirements with the requirements for AP English Language and Composition, finding balance between the two may prove to be difficult. This can result in course designs that either neglect state and district requirements or AP English Language and Composition requirements. The case studies presented in chapters five, six, and seven address the ways in which individual schools are dealing with this need for balancing a focus on writing and a focus on American Literature and present both balanced and unbalanced accounts of individual teachers trying to merge the multiple requirements.

\section{Nonfiction Texts}

The focus on American Literature lends well to the course goal having students read a variety of nonfiction texts. Following the guidelines and course description, Stella, Sophia, Henry, and Owen all make direct comments concerning the inclusion of nonfiction texts in their syllabi. Stella includes the Representative Authors for AP English Language and Composition from the Course Description verbatim in describing the types of texts that students may encounter during the course. In using this document, she foregrounds nonfiction prose and reinforces nonfiction texts as a major genre of study for this course. Sophia, again, does not provide as much specific information but is clear that many nonfiction texts are included in her course. Henry is more direct in centralizing the place of nonfiction texts within the course. He states that "[u]nlike your other English classes, this course will be focused on non-fiction work, especially essays and speeches" (1). Similarly, Owen's syllabus reveals the focus on nonfiction by including specific titles that the students can expect to read at each stage of the course. In short, the teachers participating in this study all heavily rely on nonfiction texts and work to foster 
familiarity in analyzing these types of texts in order to prepare students for the AP English Language and Composition exam and for postsecondary experiences.

The inclusion of nonfiction also becomes important when considering the course in light of its connections to first-year composition courses. Nonfiction texts make up the majority of reading assignments students in first-year composition courses are asked to complete. For example, many anthologies of nonfiction essays are designed for use in first-year writing courses and many reading sections of first-year writing textbooks are comprised mostly of nonfiction texts.

\section{Vocabulary}

In addition to focusing on reading comprehension, AP English Language and Composition courses in this study encourage the development and acquisition of a broader vocabulary. Stella states that she "will provide instruction and feedback on...a wide-ranging vocabulary used appropriately and effectively" (1). Similarly, Sophia asserts that she "will provide instruction and feedback on your writing assignments, both before and after you revise your work, that will help you develop...a wide-ranging vocabulary used appropriately and effectively" (2). Owen includes a separate section on vocabulary in his syllabus. In this section he states that, "[v]ocabulary will be stressed in every reading and writing assignment. They [students] will compile their own list from past SAT word lists and will be required to incorporate a set number (from 7-10) on each of their writing assignments" (2). The focus on vocabulary is much needed. Many students enrolled in the participating schools struggle on the multiple choice section of the exam because of a limited vocabulary. In fact, the single largest problem that I observed students having with multiple choice practice questions centered on not knowing what the words in the questions meant and therefore choosing the wrong 
answer. Moreover, many of the questions directed at the teacher during multiple choice practice time had to do with defining terms. This becomes problematic because students are not allowed to use any outside resources when taking the AP English Language and Composition exam and must rely on their own vocabulary knowledge.

Although incorporating strategies to increase students' vocabulary is important and useful, the way it is being achieved in AP English Language and Composition is potentially problematic and is directed by pressures presented by and in the AP English Language and Composition exam. Research has demonstrated that vocabulary instruction is most effective when it is contextualized within other learning experiences. Perhaps, it would be more effective, and students would have a higher chance of retaining newly acquired vocabulary words, if vocabulary instruction were contextualized and embedded within the reading experiences of the course. For example, instead of Owen having students select vocabulary words for past SAT lists, they could identify and select vocabulary words from the nonfiction and fiction texts that they are reading for the course. Moreover, research examining vocabulary acquisition in secondary and postsecondary environments cautions the potential ineffectiveness of decontextualized vocabulary instruction (Bromley; Dixon; Willingham \& Price).

\section{Current Events}

The AP English Language and Composition course is also designed to create an awareness of current events and the cultural impact of texts, which may implicitly speak to the types of dispositions that the course seeks to foster in students. Stella, Henry, and Owen all make specific references to students growing in awareness of current and cultural events. Stella has students complete multiple assignments where they "locate, print, read, and annotate a current editorial by a writer of national or international 
recognition" (19). Similarly, Henry explains that "[s]ince rhetoric surrounds us every day, and AP students are expected to keep up with the events of the world, we will take a 'news quiz' each week” (2). Along the same lines, Owen includes a special section on "Connectivity" in his syllabus where he links being informed and the effective analysis of rhetoric. In this section, he states that "[b]eing able to connect cultural, historical and philosophical precepts to writing is integral for a full understanding of an author's use of tone, voice, and desired effect" (2). In short, this focus on current events can be seen to promote the development of dispositions. This is further addressed in the following section.

\section{Rhetoric}

The course also promotes rhetorical skills and an awareness of the rhetorical situation. This course is labeled "the rhetoric course" by the College Board. Stella, Sophia, Henry, and Owen all emphasize that AP English Language and Composition focuses on students being able to understand, identify, and implement rhetorically effective strategies in their reading and writing. Teaching students to be rhetorically savvy in reading, interpreting the messages of others, and constructing one's own arguments are evident throughout all of the reading and writing assignments that students are asked to complete. Introducing students to the elements of the rhetorical situation, rhetorical devices, and audience expectations allows students to become critical consumers and thinkers. Ultimately, rhetorical awareness within the course is closely tied to the fact that the AP English Language and Composition exam requires students to complete a timed writing rhetorical analysis of a selected text. Therefore, in order for students to be successful on the AP English Language and Composition exam, these skills must be sponsored. 
Interestingly, the framing documents for the course promote and encourage the development of rhetorical literacy. Yet, it appears as though the framing documents also question the secondary English teacher's ability to support and lead students in developing rhetorical literacy skills. This is evident in a few ways. First, Puhr explains that "teachers...may have decidedly mixed feelings" when she tells them "that the AP English Language and Composition is essentially about the theory and practice of rhetoric" (Teacher's Guide 7). She asserts that many of these feelings of uncertainty about rhetoric come from the ways in which popular culture has represented what the term means. Secondly, she claims that teachers may be wary of rhetoric because "AP English Language teachers may have had little formal preparation in the subject and may wonder, therefore, how teaching students about the theory and practice of rhetoric fits within their curricula and syllabi" (8). Puhr then begins the rhetorical work of selling the term and its worth to teachers by first providing a basic definition of rhetoric. She explains that "rhetoric refers to the specific features of texts, written or spoken, that cause them to be meaningful, purposeful, and effective for readers or listeners" and can be analyzed by examining the diction, syntax, and figurative language (italics original 8). She then complicates this definition by pointing out that "defining rhetoric solely in terms of textual features can lead one to think of rhetoric as...something that can be turned up, down, or off" (8) She also points out that "defining rhetoric solely in terms of textual features...eliminates any philosophical and ethical dimension from rhetorical activity" (8). This allows her to expand the definition of the term to encompass the function that rhetoric performs. The expanded definition of rhetoric that Puhr offers states that "rhetoric refers to the art of finding and analyzing all the choices involving language 
that a writer, speaker, reader, or listener might make in a situation so that the text becomes meaningful, purposeful, and effective for readers and listeners" (8). With this expanded definition, the focus becomes more on how the features of the text are working and what impression they have on the audience given the situation. She leaves AP English Language and Composition teachers with six resources for further reading on rhetoric, all of which are popularly used with graduate students in Rhetoric and Composition. The suggested reading leaves the impression that many teachers in the target audience for this document-AP English Language and Composition teachersmust form for themselves a basic understanding of what rhetoric is and how it functions so that they can turn around and teach the course. It seems as though the type of literacy — rhetorical — that is central to the course needs first to be fostered in those individuals teaching the course before it can adequately be extended to students enrolled in the course.

\section{Exam Preparation}

Not surprisingly, AP English Language and Composition also creates a familiarity with the AP exam. However, the degree to which this occurs is heavily dependent on the teacher. For example, Stella includes a minimal amount of explicit AP exam preparation and what is included is limited to diagnostic multiple choice exam preparation and practice composing responses to released AP prompts. In contrast, Sophia is more direct in including exam preparation in her course. Sophia includes a separate section on her syllabus that describes the place of AP exam preparation in the course. She states that “[e]ach quarter, we will pair released items from the AP Language and Composition Exam in past years that are related to our unit focus, practicing the annotation of passages given on the exam and the answering of multiple choice questions" (2). Exam preparation 
is frequent, deliberate, and explicit in Sophia's class. Henry's course is also organized so as to prepare students to take the AP exam and explicitly states so in his description of the course. Yet, this preparation is embedded in the course with formal writing assignments designed so that "[s]ome of these papers will mirror the essays one will found on the AP...test" (2). Henry's class also includes practice exam essays as in class informal writing. Owen is also explicit in the presence of exam material in his course. In the schedule incorporated into his syllabus, he includes a section on "Test Prep" in each grading period. Throughout the year, the students will practice "prompt analysis, multiple choice example[s], rhetorical analysis, timed writing [and] open argument, synthesis question, rhetorical analysis, visual analysis, timed writing [and the] synthesis question" (4). With these differences in mind, it must be considered that Stella is teaching the best students in the district while Sophia is teaching at a Persistently Low Achieving school and participating in Advance Kentucky. Despite this variety in emphasis and approach, all of the courses discussed here fulfill the requirements for AP English Language and Composition because they are designed to create learning experiences that have the potential to lead students to demonstrating competency in the outcomes.

The constant presence of the exam complicates the learning environment and causes contradictions to arise between cultivating dispositions for success and preparing students to take the exam. While the teachers of the course are preparing students and trying to cultivate the dispositions necessary to succeed in postsecondary education, they must also prepare students for the AP English Language and Composition exam. This duality results in some tensions, as mentioned earlier, between the classroom practices that promote dispositions found in the Framework and the exam. Moreover, while the AP 
English Language and Composition exam does assess the outcomes described by the College Board for the AP English Language and Composition course, it, at the same time, limits those outcomes to the demonstration of skills that can be completed under the constraints provided by the exam. Therefore, some of the classroom practices—such as the controlled nature of the writing process and focus on the 3.5 essay at Green Gables High School, the focus on vocabulary instruction at Red River High School, and the emphasis on responding to practice exam prompts and other timed writing exercises at Orange Tree High School and Violet Fields High School—contradict the classroom environments and practices that work towards cultivating the dispositions found in the Framework. Students are not demonstrating creativity, curiosity, responsibility, or flexibility when they compose essays by filling in templates, choose vocabulary words from a decontextualized list, or practice writing responses for the exam. They are practicing for the assessment. While it is understandable that test preparation is part of AP English Language and Composition, assessing reading and writing through the use of timed-writing assessments works against some scholarship in Rhetoric and Composition (Albertson \& Marwitz; Cho; Del Principe \& Graziano-King; Huot). However, it must not be forgotten that the AP English Language and Composition exam is just one day in the course and one part of the AP English Language and Composition experience.

Although the presence of the AP English Language and Composition exam imposes restrictions on the course, not all of the learning experiences designed by the teachers operate within these restrictions. And not all class experiences are tied to the ways in which the AP English Language and Composition exam assesses the outcomes of the course. For example, the research project that Stella has students at Violet Fields High 
School complete, the focus on current events that Henry emphasizes with students at Orange Tree High School, and the outside reading and writing projects that Owen's students at Red River High School complete all are designed to meet the outcomes of the course and cultivate dispositions for success. These are just a few of the many examples where teachers are using the outcomes from the AP English Language and Composition course and designing learning experiences that work to cultivate the dispositions called for in the Framework.

\section{Instructional Practices}

It cannot be denied that the AP exam is constantly and continuously present in the AP English Language and Composition course, and its presence imposes, sometimes inadvertently, restrictions. Assessment is a constant presence in education and has a particularly longstanding historical presence in the AP program. Because AP English Language and Composition teachers need to prepare students to take the exam, the form and content of the exam informs and underlies the decisions that the teachers make, even though conflicts arise between preparing students for the exam, competency in meeting the outcomes, and in fostering the dispositions identified in the Framework. However, the AP English Language and Composition course is more than just the exam. While the students are assessed for competency over the outcomes on the exam, they also demonstrate competency of the outcomes in other, less sanctioned, ways throughout the course, such as formal writing projects and group discussions. The classroom practices encompass the outcomes in a variety of ways, even if the exam is asking students to demonstrate competency in narrowly prescribed ways.

The course experiences discussed in this section provide students with time, space, and material that allows them to fulfill their purpose, whether that be the 
possibility of precollege credit for writing or a rigorous curriculum that prepares them to enter college ready to enroll in first-year composition. While it is reassuring that many overlapping and complimentary experiences are occurring across locations within this particular district, it must also be acknowledged that there were many AP English Language and Composition teachers within Jefferson County Public Schools that either declined to participate in this study or did not respond to my initial research request. Nevertheless, these four locations, as the above analysis into syllabi, course materials, and conversations show, demonstrate the ways in which AP English Language and Composition is operating to encourage literacy experiences that will cultivate dispositions that students need to develop in order to experience a greater chance of success when they enter postsecondary institutions.

\section{Cultivating Dispositions for College Readiness: The Framework for Success in Postsecondary Writing and AP English Language and Composition}

In this section, I look more closely at the ways in which the dispositions identified in the Framework are operating through the literacy experiences outlined above. This investigation is important because it shows connections between practice at the local level and traits important for college readiness. In introducing the Framework and the AP English Language and Composition outcomes, I worked to establish connections between the two documents in chapter three. As chapter three demonstrates, the outcomes for AP English Language and Composition work to promote the dispositions included in the eight habits. Moreover, as the previous section of this chapter shows, the teachers participating in this study are adopting and adapting the outcomes described by the College Board and cultivating certain types of learning environments. In short, this 
section focuses on connections between the dispositions described in the eight habits and the AP English Language and Composition courses participating in this study.

Even though there are practices that exist within AP English Language and Composition that focus more on exam preparation than assisting students in developing dispositions, what follows looks at multiple ways that the AP English Language and Composition courses of Stella, Sophia, Henry, and Owen work to cultivate habits of mind linked with postsecondary success in writing. Although practices are occurring in AP English Language and Composition that contradict the Framework and approach the outcomes for the course in a narrow fashion that mimic what the exam asks students to do, the focus of the following analysis is on the learning experiences that address the outcomes for the course and work to cultivate dispositions called for in the Framework. While there are multiple possible connections between the dispositions and the course practices, this investigation begins to address a few of these possibilities.

\section{Curiosity}

The experiences included in AP English Language and Composition, and described in detail in the previous section, have the potential to encourage curiosity through multiple avenues. Students are encouraged "to know more about the world" when they work to expand their vocabulary because they are figuring out ways of investigating and figuring out things that they do not already know (528). This can be seen in Owen's course when he calls on students to self-select vocabulary words, become familiar with those terms, and incorporate them into their own writing. Curiosity is not only promoted through vocabulary expansion, it can also be fostered through the types of texts that students are asked to read. For example, Stella, Sophia, Henry, and Owen all stress the importance of reading nonfiction texts and current events for students enrolled 
in AP English Language and Composition. This type of reading has the potential to develop curiosity in students because they are being encouraged to read texts that are unfamiliar and explore issues that they may not have considered previously. While the texts that students read present the potential to encourage curiosity, this disposition is encouraged even more through the writing experiences that students are asked to complete. This is most evident in Stella's course when she requires students to complete a multi-process research project using outside resources. In conjunction with the writing assignments, the writing process is also fostering curiosity in students and this can be seen in Sophia's course when student complete their "down and dirty outlines" (Interview 24 March 2014). Through these types of projects and processes students are encouraged to explore the world around them and interact with texts in a way to satisfy and extend their curiosity. Finally, the emphasis on rhetoric in the AP English Language and Composition course also has the potential to cultivate curiosity in students because, as all of the participants in this study show, rhetoric is tool that students can use to investigate the world around them. In short, curiosity is a habit that is developed in multiple ways in the AP English Language and Composition course and, as the Framework argues and previous research shows, students who are curious are likely to be more success in postsecondary education.

\section{Creativity}

Not only are teachers trying to cultivate curiosity in students enrolled in AP English Language and Composition, creativity is also being promoted in multiple ways. Students are encouraged "to use novel approaches for generating, investigating, and representing ideas" through the writing assignments, focus on rhetoric, and in conjunction with texts that they read (528). For example, in Henry's class students are 
asked to complete multiple writing projects that have them composing in a variety of modes. In this process, Henry is encouraging students to consider the ways in which topic, purpose, and audience fit together and students must exercise creativity in figuring out how to best respond to the assignments, given the constraints of the rhetorical modes that Henry provides. Creativity is also evident though the focus on rhetoric and this is seen in Owen's course when students are instructed to complete multiple rhetorical analysis essays on various texts that they are reading. Moreover, when students are asked to interact with current events, as they are in Stella, Henry, and Owen's class, they are figuring out ways of interacting with the world around them and pose informed questions. In short, creativity is fostered in AP English Language and Composition through multiple learning opportunities that call on students to question and follow-up on those questions, similar to the inquiry experiences that students will need to complete to be successful in postsecondary education.

\section{Responsibility}

While curiosity and creativity are seen in multiple aspects of AP English Language and Composition, the experiences the course provides also help students develop responsibility. Students are encouraged "to take ownership of one's actions and understand the consequences of those actions for oneself and others" through the writing assignments, use of the writing process, and in preparing to take the AP exam (528). For example, when students in Owen's course complete formal writing assignments on fiction texts, they are demonstrating responsibility because these assignments take place completely outside of class time and students must pace themselves and structure their time to have the assignment completed by the due date without having any class time to work on it. A similar situation is also true for Stella's students. Students in AP English 
Language and Composition also demonstrate responsibility through the ways in which Stella, Sophia, Henry, and Owen incorporate the writing process in the course. In all instances, the students take a certain amount of responsibility in guiding their own writing process, and as Stella, Henry, and Owen make clear, must take the initiative to schedule a writing conference with the teacher. Furthermore, responsibility is also fostered through the amount of preparation that students must spend getting ready to take the AP exam. This can be seen most clearly in Sophia's and Owen's courses where students must make the decision to stay afterschool for additional preparation or attend Saturday sessions in order to aide in preparing for the exam. Additionally, the amount of coursework and the level of challenge that the coursework provides also helps cultivate responsibility in students. AP English Language and Composition is a difficult class with a heavy workload, as the teachers in this study make clear in their course syllabi and assignment prompts. In short, in order to complete the assignments, engage with the writing process, prepare to take the AP exam, and complete the coursework, students must demonstrate a great deal of responsibility.

\section{Flexibility}

In addition to responsibility, AP English Language and Composition encourages and promotes the cultivation of flexibility. Students are encouraged "to adapt to situations, expectations, or demands" when they engage with the writing process, read unfamiliar texts, and prepare to take the AP exam (529). For example, when students in Stella's, Sophia's, Henry's, or Owen's class engage with the writing process they should be open to the critique and feedback that they are receiving from peers. The call to see their writing through the eyes of someone else requires students to be flexible and responsive. Moreover, students are called on to exercise flexibility through the texts that 
they read for this course because, for many of the teachers, students are being asked to rhetorically analyze multiple types of texts, including American Literature, fiction, nonfiction, and current events. As Owen explains, he expects students to be able to analyze any text that is put in front of them on the AP exam. Flexibility also becomes extremely important for students taking the AP exam because, while they know what types of questions will appear on the exam, they do not know the content of the questions. Thus, being able to be flexible in the exam setting is invaluable.

\section{Openness, Engagement, Persistence, and Metacognition}

Although not cultivated as often or an intensely as the other habits, AP English Language and Composition also encourages students to develop openness, engagement, persistence, and metacognition. These habits are fostered through writing assignments, reading assignments, preparing to take the AP exam, and in reflecting upon one's progress that comes at multiple stages of the course. Students develop openness and "the willingness to consider new ways of being and thinking in the world" when they read a variety of texts (Framework 4). This can be seen in Stella's, Henry's, and Owen's course when students interact with current and cultural events, such as when Stella's students respond to current editorials with a reasoned argument, or when Henry's students take their weekly current events quizzes, or even when Owen pushes students to consider the ways in which culture is operating in a text. Furthermore, students demonstrate engagement when they have "a sense of investment and involvement in learning" (Framework 4). This is also evident in Stella's course when students design and complete long-term research projects or working on independent fiction reading. Furthermore, students demonstrate persistence and "the ability to sustain interest in and attention to short - and long-term projects" when they are asked to complete writing projects outside 
of class, as both Stella and Owen require student to do with novel analysis projects (Framework 5). Finally, students demonstrate metacognition and "the ability to reflect on one's own thinking as well as on the individual and cultural processes and systems used to structure knowledge" when they reflect on their progress in the course and after taking the AP English Language and Composition exam (Framework 5). For example, Stella's students write a written reflection with their research project that asks them to consider: "How has this experience helped you improve as a student in general and as a writer" (19)? "What are some valuable lessons you have learned from this experience that any student can apply to future academic pursuits" (19)? "How does this writing/research experience compare to your other writing/research experiences in the past" (19)? These questions ask students to reflect on their practices, successes, and failures during the project. Another example of this is when Owen asks students how they think they did after taking the AP English Language and Composition exam.

While curiosity, openness, engagement, creativity, persistence, responsibility, flexibility and metacognition are all fostered in AP English Language and Composition, some dispositions are more central to the course than others. Despite this unequal treatment, the cultivation of these habits helps prepare students to develop the dispositions necessary to be successful in college. Perhaps the eight habits of mind are enacted in different ways for different purposes, sponsoring students differently based on needs and the eight habits show themselves differently based on these differences. This may mean that curiosity for Stella's students looks very different than curiosity for Sophia's students. Yet, all of the AP English Language and Composition teachers participating in this study are working, some explicitly and others implicitly, to help 
students cultivate dispositions and character traits that will assist them in being successful when they begin their postsecondary careers.

\section{AP English Language and Composition and Literacy : A Few Concerns}

While the above recognizes the positive experiences that are occur within AP English Language and Composition, competing and conflicting values are present at times. These negative experiences include the financial gain the that College Board receives from teachers and students, AP courses setting up the expectation for a particular postsecondary educational experience, and teachers teaching to the exam in order to increase pass rates.

While the College Board is actively sponsoring a certain kind of literacy through the design of the course, goals, and expected outcomes that are proven to increase the chances of student success in college, they also have a financial stake in the number of students enrolled and this influences the ways in which literacy is sponsored throughout AP English Language and Composition. So, even though the College Board criticizes "gatekeeping" and "screening requirements" that some school use to block enrollment in AP courses, a possible reason behind this critique could be associated with the gain that the College Board sees as enrollments increase. The College Board also make a great deal of money off AP programs — both students and teachers — while providing little oversight with the exception of the syllabus audit, exam creation, and scoring. As Stella makes clear, "we [teachers] also have a problem because the College Board...make[s] a whole lot of money off of us... a whole lot of money and we have problems with that too" (Interview 13 March 2014). Along the same lines, Owen questions the motives behind the College Board's push for open enrollment in AP courses. He explains, "I think what 
you are seeing with AP is that they want their money. So, it behooves them the more people enrolled" in their courses (Interview 20 March 2014).

AP English Language and Composition anticipates that students will be entering a particular type of postsecondary institution upon completion of secondary education. This leads to a narrow conception of what college writing may be like. Moreover, this attitude is repeated and taken up by teachers of the course. For example, a certain attitude surrounds students traditionally served by using AP English Language and Composition as a source of precollege credit for writing. Stella exhibits this attitude when talking about whether or not students completing AP English Language and Composition should be required to enroll in some type of first-year college writing when they enter their chosen postsecondary institution. She explains, "I can tell you my opinion being at basically the top school in the state. There are going to be kids who get into the 102 class at $\mathrm{U}$ of $\mathrm{L}$ and even at some place like Harvard who really don't need to be there and who are going to be really bored" (Interview 13 March 2014). She continues to explain, "and I completely understand that you want to have a consistent... curriculum and skills that you want them to have before they move on but there are going to be kids that come that already have that. It seems kind of unfortunate for those kids to punish them and make them take the class again and to make them pay for the class they don't need to take" (Interview 13 March 2014). Owen also comments on this issue, but takes a slightly different perspective. He explains that "I would say a 3, 4, or 5 on AP exam should get you out of a base level 101, you don't need to freaking take that. Should you have to take a 102 ? Yes... That 102 class needs to be this is what UL's research facilities look like. Here are the things available, here's how you do research. Here's how you compile 
research. Here's how you compile evidence for research. That is what it should be for" (Interview 20 March 2014). In short, these teachers are talking about certain types of students that probably already had developed some of the dispositions that will help them be success in college before they entered AP English Language and Composition; they are not talking about the types of students served by the push for open enrollment in AP courses. And, in Owen's case, he is identifying a particular skill set-researching at a particular place - that he feels he cannot provide students based on location and resources. Similarly, while the Common Core State Standards promote college and career readiness, the literacy experience provided by AP English Language and Composition, and the teachers interviewed for this project, favor college readiness because of its historical ties as a means for gaining college credit. However, the curriculum of the course very easily lends itself to also making student career ready. Yet, fostering career readiness is overlooked.

Teachers may also result to teaching directly to the test in order to boost scores because of incentives attached to AP pass rates and certain programs, such as Advance Kentucky, seek to compensate teachers for passing scores on the exam. While motivating, the financial incentives for student achievement on AP exams is problematic for a couple of reasons. First, it shifts the conversation from learning and college preparation to financial gain. Second, with the incentives tied to exam scores, the risk is present that teachers will focus on strategies to increase exam scores, while ignoring the development of dispositions. As with any standardized assessment, the exam presents a selection of skills that should have been covered throughout the course but attaching 
financial incentives to particular achievement levels shifts the focus to performance on the assessment and away from the learning experiences.

\section{Conclusions}

By illustrating the ways in which AP English Language and Composition overlaps with the eight habits promoted in the Framework, I have attempted to show the ways in which the course is operating not only as a site of precollege credit for writing but as a site of college preparation for many students through fostering literacy experiences and cultivating dispositions for success. The literacy experiences encouraged assist students in developing the necessary dispositions to enter college and experience success. AP English Language and Composition makes an important contribution to the conversation concerning college readiness at state and local levels because of its dual function of being a site of precollege credit for writing and as a site of college preparation. Not only has the correlation between AP courses and later college success been proven by research, the teachers in this study, especially those encouraging participation from students not traditionally involved in the AP program, echo the ways in which AP English Language and Composition works to prepare students for college, and specifically the types of writing that they will be asked to complete in college. In short, AP English Language and Composition works as a particular kind of response to the conversation on college readiness by fostering dispositions that have been proven to lead to later success through sponsoring various literacy experiences that encourage the development of habits of mind and align with the curricular goals and outcomes laid out for the course by the College Board.

This chapter has focused on shifting the conversation surrounding AP English away from emphasizing the AP exam and towards an emphasis on the learning 
environments created through classroom practices as described in course documents and by teachers. When the conversation shifts from assessment measures to the learning environments created in these spaces, the ways in which dispositions are cultivated to promote college readiness through literacy experiences in the AP English Language and Composition course is revealed. 


\section{CHAPTER 5: EXCEPTIONAL CONSTRUCTIONS OF AP ENGLISH LANGUAGE AND COMPOSITION: A LOOK AT ONE TEACHER'S PRACTICE AND PHILOSOPHY}

AP English Language and Composition appears to be a stable entity, as it is described by the College Board. Yet, the College Board is quick to point out that there are multiple ways in which the course can be enacted and still meet the outcomes and requirements necessary to carry the "AP" label. The Teacher's Guide explains that "Because...the AP English Language and Composition... [exam is] skills-based as opposed to content-based, teachers have tremendous latitude in designing their classes" (xxi). This "tremendous latitude" is positive in many regards because it allows teachers to utilize their strengths, make good use of the resources available at their school, and focus on the student population that is served by their school. However, it also guarantees differences will exist among student experiences. Therefore, even though the AP English Language and Composition outcomes and exam act as boundary objects that guide the course at multiple locations, the specific ways in which the course is enacted is heavily influenced by the school's history, the resources available, the history and philosophy of the teacher, and background and goals of the students. This chapter explores the ways in which AP English Language and Composition is enacted at an affluent school with ample resources and privileged students in order to show the strong connection that the course can have to first-year writing given plentiful resources and well-prepared students. 
This is the ideal world here and I know that it is the ideal world. A lot of the things I do here, I would not be able to do elsewhere, or I would have to do half as much as I do because the pace is really fast and the workload is really intense. So, somewhere else, I would have to lower it.

-Stella (Interview 13 March 2014)

\section{AP English Language and Composition at Violet Fields High School}

As the above quote indicates, the case study at the center of this chapter was performed at a high-ranking school, where the resources are abundant and students are exceptionally well prepared for academic achievement. The descriptions and analysis that follow reflect the unique circumstances of the ways in which the AP English Language and Composition course is enacted at this particular location.

Fitting with the historical origins of the AP program and the long-standing practice of associating AP coursework with gifted or advanced students, Violet Fields High School sets requirements ${ }^{35}$ for students wishing to enroll in AP English Language and Composition. Furthermore, Stella ${ }^{36}$, the AP English Language and Composition teacher, explains on her syllabus that because:

teacher recommendation is a requirement for this course, an assumption is made that students have already developed a command of Standard English grammar and mechanics. Ideally, students in this course should have good to excellent reading and writing skills. Those who struggle with the fundamentals of grammar, with developing ideas, or with advanced-

\footnotetext{
${ }^{35}$ These requirements include teacher recommendation, GPA, and scores on standardized assessments.

${ }^{36}$ For more information about Stella's training, see chapter two. The 2013-2014 school year was her $8^{\text {th }}$ year teaching AP English Language and Composition and her $13^{\text {th }}$ year teaching with the district. She attended the Advanced Placement Summer Institute Training at Western Kentucky University before she started teaching AP English Language and Composition.
} 
level reading will have difficulty succeeding in the course. In addition to these skills, the ability to think abstractly, interpret and read beyond the surface or for mere plot summary are keys to success. (1)

As this passage indicates, this course is designed for students already mastering grammar conventions and are ready to compose at a more advanced level. Moreover, because this passage indicates that students should already have developed "good to excellent reading and writing skills" the course is framed as a space for advanced students to further develop their craft, not as a space where developing or emerging writers will have the support necessary for them to work with challenging material. Students still developing certain cognitive processes that allow for abstract thinking are also cautioned against enrolling because the course is based on the assumption that students will already have developed the ability to think abstractly. However, Stella does explain that she "think[s] any student willing to take on the challenge of an AP course should be encouraged to do so; however, they need to be fully aware that they may struggle all year and they will likely not earn an A or perhaps even a B if they start with really low skills" (Philosophy 2). In short, although all students wanting to enroll are encouraged, students not already performing at an advanced level are not sought out and encouraged to enroll. The responsibility rests with the student to seek out, enroll, and perhaps struggle throughout the course. AP English Language and Composition at Violet Fields High School is designed for students already performing at an advanced level and this is similar to the type of student originally imagined as enrolling in AP courses by the College Board. These students are ready for college-level coursework and enroll in the course with the intention of using a passing score on the AP English Language and Composition exam to 
bypass first-year composition when they enter their postsecondary institution. Therefore, Stella's approach reflects the fact that AP English Language and Composition is functioning as a site of first-year writing for many of the students at Violet Fields High School.

In this chapter I investigate the practices of Stella's AP English Language and Composition course at Violet Fields High School. As described in chapter two, Violet Fields High School is a magnet school that is highly ranked in the state. It offers 27 AP courses, the most of any high school in Kentucky, and has the highest ACT average of any high school in the state. First, this chapter explores Stella's approach to the course and teaching philosophy. Following Stella's perspective on the course, this chapter investigates the instructional approaches that she employs using interview material and textual documents provided by Stella. The chapter then moves to discussing the implications of this type of AP English Language and Composition course on students entering postsecondary education.

I constantly ask myself how every activity, assignment, and assessment will help my students be successful in their future endeavors: college, graduate school, the workplace. I try to eliminate busy work; there is no fluff. I want my students to understand why I am asking them to do something. Basically, this means if I expect my students to work really hard that I also have to work really hard. I want them to see my passion and enthusiasm; when we cover topics I don't particularly like to teach (i.e. grammar), I try to help them see why it is important even if we don't like it. -Stella (Philosophy 2) 


\section{Instructional Approach and Teaching Philosophy}

Stella clearly teaches AP English Language and Composition as though it were a college-level course. As the opening quote for this section shows, the students' imagined futures, and the skills that students will need in these futures to be successful, are at the center of the planning for this course, and college is the next immediate step for most students at Violet Fields High School. Furthermore, the amount of writing that students are completing exceeds the amount that they would be asked to complete in the typical first-year class when compared to the total number of pages suggested for first-year writing at the University of Louisville ${ }^{37}$. For example, at the end of the course, Stella provides students with a list of the different types of writing that they have completed over the course ${ }^{38}$. For instance, students complete the following writing tasks: Writing to Learn, Writing to Demonstrate Learning, Writing for Publication, Informative / Explanatory, Narrative, Argument, Writing that was Peer Workshopped, Writing that was Self-Scored, Writing that Required Research \& Documentation, Reflective Writing, SelfAssessment, Editorial Fridays, AP Free Response Essays, RASARs, Summaries, NoteTaking. Additionally, the types of writing and reading assignments that students complete closely align with the types of assignments included in many first-year composition courses at many postsecondary institutions. While this list encompasses both informal and formal writing, it is important to note that students are completing eight formal writing assignments that total forty-five plus pages of text. When considering only the formal writing assignments, the students are composing a personal essay, an extensive

\footnotetext{
${ }^{37}$ According to the Student Learning Outcomes for the University of Louisville, English 101 students "should expect to write four-to six papers during the term totaling about 18 to 20 pages of text" (UL Composition Student Learning Outcomes). English 102 students "can expect to write four to six papers during the term, including at least one extended research essay, totaling 20 to 25 pages of text" (UL Composition Student Learning Outcomes).

${ }^{38}$ Writing Completed in AP English can be found in the appendix.
} 
research project ${ }^{39}$, persuasive speech, satirical essay, and two literary analysis papers. This number does not even include the twelve released AP English Language and Composition essay prompts that students respond to, the five editorials that they compose, or the writing responses that they complete in response to reading assignments.

Not only does Stella strive to create a college-level course, she challenges students by continuously increasing the rigor of her course. An essential part of Stella's approach and philosophy is a rigorous curriculum that incorporates the standards from the state and district with the outcomes outlined by the College Board. Stella explains that she has "ramped it up every year" (Interview 13 March 2014). She continues to discuss this topic in her teaching philosophy when she explains that she "reflect[s] constantly on the design of...[her] curriculum; so,... [she] makes changes every year. It took... [her] 3 full years of teaching this course before...[she] felt like...[she] truly had a handle on everything...[she] needed... [her] students to know" (Philosophy 1). However, she is also quick to point out that once she finds something that meets the goals of the course and works well for students she makes very few changes.

While the rigor of the course is always a focus and changes occur from year to year to increase the rigor, setting high expectations for students is also a priority. AP English Language and Composition at Violet Fields High School is challenging and students must determine the amount of work they want to put into meeting the expectations set by Stella. Stella explains that there is "a huge range in class" in terms of students' abilities when they enter the course, even though she does indicate that the students in her AP English Language and Composition course are meeting college readiness benchmark scores in Reading and English (Interview 13 March 2014). She

\footnotetext{
${ }^{39}$ This writing project will be examined in more detail later in this chapter.
} 
continues to explain that "everybody goes up but they don't all get to the same level" (Interview 13 March 2014). She also explains that she "set[s] the bar extremely high...because...[she] find[s] that the majority of...[her] students will meet those expectations adequately, some will surpass them, and a spare few will struggle and/or fail to meet them. However, even the students who struggle to fail to meet...[her] extremely high expectations still improve in one or all of...her key elements" (Philosophy 1-2). One of the ways in which Stella establishes high expectations for students is by using exemplary writing from past students as examples in her instruction. She shared with me an outstanding model of a researched argument paper and explained that she "was probably not writing like this [student] in college, even at the end of college" (Interview 13 March 2014). However, Stella is adamant that it is up to the individual student to “decide how far they are going to push themselves" (Interview 13 March 2014). Stella's attitude concerning the student's own responsibility for individual success is more aligned with attitudes expressed by first-year writing instructors than high school teachers. For instance, it is the students' responsibility to recognize that they need a conference over their writing and contact Stella to schedule one. Moreover, students must decide how much time they are going to devote to outside of class assignments. She reflects that "[i]n the long run, most students appreciate being pushed, so they learn how to be successful in a really difficult course" (Philosophy 4), and this is an experience that they will benefit from when they enter postsecondary institutions.

Not only does Stella hold high expectations for students, she also holds high expectations for herself and frequently engages in reflective practice and makes adjustments to her teaching. A central aspect of Stella's teaching philosophy is that she 
"make[s] an effort to learn new content every year to make sure that...[she is] keeping up with the most current pedagogies, skills, types of assessment, etc. This means that...[she] often add[s] new things that are valuable and will help...[her] students in the future" (Philosophy 1). This continued learning is evident in Stella's very deliberate selection of material and creation of assignments that help foster the goals and outcomes of the course and prepare students for experiences that they will encounter in postsecondary writing assignments. Moreover, Stella's thoughtful and deliberate course design is informed by the ways in which she interprets the purpose and function of AP English Language and Composition as it is set-up by the College Board. It is because of Stella's challenging curriculum, rigorous pacing, and expectations for student responsibility that AP English Language and Composition course at Violet Fields High School is the equivalent of a first-year writing course. I would argue that Stella's approach to writing instruction is even more aligned with college writing instructors than it is with secondary writing instructors.

Looking at the College Board's course description and their suggested...possible syllabi...it was really clear to me that the focus of the course was argument and analysis and academic writing.

-Stella (Interview 13 March 2014)

\section{Argument, Analysis, and Academic Writing}

AP English Language and Composition at Violet Fields High School is very much focused on argument, analysis, and academic writing. Stella employs a variety of instructional approaches that include small and large group discussion, the use of professional and student writing models, novel projects, and limited test preparation, to promote the critical thinking, reading, and writing called for by the College Board. As 
Stella explains, "pretty consistently... students every week are asked to read something critically where they are asked to annotate. They're reading for the purpose of understanding what the writer's purpose was and how the writer achieved that purpose. So, that is practice with rhetorical analysis skills and critical reading and then some of that is directly connected to what...[they are] writing" (Interview 13 March 2014). As Stella shows, students are using texts in multiple ways to become better critical readers and writers.

\section{Reading}

Helping students develop the ability to read critically is an important aspect of first-year composition. In "Who is Teaching Composition Students to Read and How Are They Doing it?" David Jolliffe wants teachers of writing to teach reading deliberately. He contends that "Students don't come to college knowing how to read carefully and critically. They seem to think that reading consists of putting their eyes on the first word, moving them over each line, and then stopping when they reach the last word. They skim. They glance. They don't connect" (127-128). Moreover, Linda Adler-Kassner and Heidi Estrem argue for the importance of focusing on reading in first-year writing courses by looking at the ways in which reading was included in first-year writing courses at their institution. They came to the conclusion that "Articulating the kinds of reading that are enacted in classrooms and the roles that readers are expected to perform within them can open important conversations that enable instructors (and/or programs) to more productively approach reading" (44). Furthermore, Dan Keller, in "A Framework for Rereading in First-Year Composition" urges first-year writing teachers to reconsider the ways in which reading appears in their course and calls for fewer texts and more in-depth work with those texts. He asserts that "if we want to help students grow as attentive, 
critical readers, then we should examine how reading fits into composition's curricular space, which means asking questions about how many texts we assign as readings" (45). In short, reading is an important part of the first-year writing course and its place in the first-year writing curriculum is gaining increased attention. Therefore, the fact that Stella's AP English Language and Composition course focuses on critical reading aligns with practices seen in recent discussions concerning pedagogical choices in first-year composition.

\section{Discussion}

Small and large group discussions are a common practice in AP English Language and Composition at Violet Fields High School. Discussion formats range from formal Socratic circles with set procedures and teacher created prompts, to informal table discussions, to fish bowl discussions, to large group discussions that coincide with material that Stella is presenting in lecture format. These discussions are centered on a variety of college-level texts. For example, students read material from The Informed Argument, Classical Rhetoric for the Modern Student, Prentice Hall Literature: The American Experience, Elements of Writing, Fifth Course, The Norton Reader, Picturing Texts, 50 Essays: A Portable Anthology, Everything's An Argument, Ways of Reading, $4^{\text {th }}$ edition, The St. Martin's Guide to Writing, novels, and other current events non-fiction texts. Stella explains that no matter what type of discussion the students are participating in she stresses four things. These include: "asking questions of the text, making text references in your discussion, making connections... and playing devil's advocate" (Interview 13 March 2014). Stella scaffolds the course so that "second semester, the expectation is that...[the students] should be able to take a text that they've read and they should be able to come in and have an in-depth scholarly discussion without any help" 
from her (Interview 13 March 2014). From interviews and examining the course material provided by Stella, it becomes obvious that her goal is to create and foster a studentcentered classroom space where she acts as the facilitator but the students are actively working with one another to meet the outcomes and goals of the course. For example, when the students are examining the Declaration of Independence, Stella constructs the questions that the students will discuss but she does not directly participate in the discussion. These questions include:

- How does the Declaration of Independence work as an argument for democratic ideals?

- How does the Declaration of Independence indicate what Jefferson thinks government should be or do (i.e. the role and purpose of government)? Will most of his audience agree with him?

- What does the statement about submitting facts to a "candid world" suggest about the intended audience?

- What is Jefferson's purpose in presenting this information?

- What is his most convincing evidence to support this declaration of independence? How would you rate his overall effectiveness?

- How does Jefferson use the forms of appeal to create an effective argument? Declaration of Independence Socratic Circle Questions, updated 11/03/2010

As these questions indicate, students discuss the Declaration of Independence as it functions as an argument and examine how it works rhetorically. While Stella could present this information in lecture format, she explains that she would much rather have 
students work through the material and come to their own conclusions. She explains that “I'm not a worksheet kind of person, nor am I a sit in your seat quietly by yourself kind of teacher either. So, inevitably, you are more likely to come into my class and find the kids working at tables together, doing fish bowl discussions or Socratic circles or whole class discussions" (Interview 13 March 2014). The importance of discussion in Stella's AP English Language and Composition course is paramount because it not only allows for a student-centered approach, but it also allows students the opportunity to develop skills—-such as holding a discussion with their peers — that they will need in postsecondary education and cultivate dispositions that have been linked to success later in life and included in the Framework for Success in Postsecondary Writing ${ }^{40}$.

\section{Modeling}

In addition to multiple types of discussion, modeling also plays a large role in AP English Language and Composition at Violet Fields High School. Students frequently read and analyze both professionally written models and student written models completed by students in past AP English Language and Composition courses at Violet Fields High School. Stella explains she "consistently [uses]...models of whatever we are writing by former students" in addition to professional models so that students can see actual writing that prior students enrolled in this course completed. Moreover, Stella comes to the conclusion that "the professional models and the student models are some of the most helpful things that...[she] use[s] in terms of resources" (Interview 13 March 2014). This is reiterated in her teaching philosophy when she describes the importance of using models with students. She says that "[i]t is essential to use models with students.

\footnotetext{
${ }^{40}$ See chapters three and four for more discussion concerning AP English Language and Composition, the Framework for Success in Postsecondary Writing, and the cultivation of dispositions linked with success.
} 
We must show them what to do and what not to do" (Philosophy 3). Stella also models for her students the skills and practices that she desires for them to acquire. For example, she explains that "when...[she is] teaching new content or skills...[she] build[s] in modeling, guided practice as a whole groups, practice with peers, individual practice, and review before...[she] asses[es] for mastery" (Philosophy 3). So, not only do the students use models for writing, teacher modeling is also important to the course. It is encouraging that Stella uses models, both from professionals and past students, in the writing instruction of AP English Language and Composition. This practice aligns with current scholarship in Rhetoric and Composition. For example, the 2010 edited collection, Teaching with Students Texts by Joseph Harris, John D. Miles, and Charles Paine explores various aspects of this practice and provides writing instructors with thoughtful considerations of both ethical and practical issues that arise when using student texts as teaching tools.

\section{Fiction}

While not a core part of the curriculum outlined by the College Board for AP English Language and Composition, the teaching of fiction novels is a core part of state and district curriculum, and therefore Stella includes them in her course. However, as Stella explains, "We only read one novel actually together and that is The Things They Carried by Tim O'Brien" (Interview 13 March 2014). The reading of this text happens in a short period of time. Stella spends "one day where... we listen to music from the era, we watch some videos about the era, you know, we talk about what the Vietnam era is all about, we talk about what modernism vs post-modernism, we do a Socratic circle on an essay that Tim O'Brian wrote called "The Vietnam In Me". And, then they read the book, the whole book, themselves" (Interview 13 March 2014). The students are then 
tested over the material and spend several days having different types of discussions about the text. Stella explains that "ultimately the goal is to transfer the skills with rhetorical analysis to literary analysis and they have to write a literary analysis of The Things They Carried. Again, something that could be published ultimately, if it was good enough. Again, scholarly writing" (Interview 13 March 2014). The fact that this unit is covered so quickly indicates the rigorous pace at which students in Stella's AP English Language and Composition course are moving. Other than this one text, students complete their novel reading outside of class. However, including this material in the course allows Stella to meet state and district requirements, while still meeting the outcomes laid out by the College Board for AP English Language and Composition.

\section{Read, Annotate, Summarize, Analyze, and Respond}

A pedagogical tool that Stella developed and frequently uses with her students is called a RASAR ${ }^{41}$. She uses this tool to help students learn to read critically. She explains that "RASAR stands for read, annotate, summarize — in a paragraph — just the basics skill of writing a brief summary, analyze, which is a rhetorical analysis and then reaction. And so the reaction is the place where they don't have to be formal, it doesn't have to be in the third person, etcetera. They can say whatever they want, however they want, basically, about what they've read" (Interview 13 March 2014). The assignment sheet for this activity explains that as students read, they should be asking themselves "[w]hat is it about" (Packet 88)? In addition to figuring out what the text is saying, students should also be annotating as they read and asking themselves "[w]hat is important" (Packet 88), and they should also be actively reading by "[m]ark[ing] key words/phrases, important dates, standout images, significant sentences, etc" (Packet 88).

\footnotetext{
${ }^{41}$ See the appendix for Stella's instructions for this activity.
} 
Additionally, they should also be "[m]ak[ing] notes \& ask[ing] questions" in the margins (Packet 88). Students then practice the skill of summarizing the material. For this part of the activity, the assignment sheet directs students to "[u]se the things you marked to write a summary of what you read" (Packet 88). Once the text has been read, annotated, and summarized, students are instructed to move on to conducting analysis. Once students complete the analysis, they then move to the personal reaction portion of the assignment. Students complete multiple RASAR responses over the course and the pattern required teaches them how to read material critically. They can and will, hopefully, use the format of the RASAR in other contexts, such as when read materials for postsecondary courses because they will mostly likely need to frequently use the skills of summarizing and analyzing in order to complete course assignments.

\section{Test Preparation}

While students enrolled in AP English Language and Composition are well prepared and meeting college readiness benchmarks, the pace of the course intense and the rigor great, Stella still spends time on test preparation for both the AP English Language and Composition exam and the state on-demand writing assessment. However, Stella is clear to point out that "[n]otice I have said very little about the test itself, because in some ways it is such an afterthought for me. However, you could also easily say 'I teach to the test' because everything I do is designed to help them be a critical reader and writer, and therefore directly prepares them for the test" (Philosophy 3). Because AP English Language and Composition engages students with rigorous reading materials and requires students to perform complex tasks, there is little need for specific test preparation. However, Stella does feel the need to help students become familiar with the format of the exam. Therefore, during the second semester of the course, there is a slight 
focus on test preparation for the AP English Language and Composition exam. As Stella's teaching philosophy describes,

Second semester I spend more time with specific test prep and more multiple choice and free response practice. By the test my students have typically taken 5 to 7 multiple choice AP exams and written 12 times, free response essays. Most of this is done for homework. I even offer a complete mock exam on a Saturday morning to help students understand what it is like to focus for 3 hours and 15 minutes with 2 hours and 15 minutes of that being writing. (Philosophy 4)

Stella also explains that the prompts that students practice with for the AP English Language and Composition exam are more difficult than the prompts for the state ondemand test. Therefore, by composing responses to released exam prompts for AP English Language and Composition students are also preparing for the state on-demand assessment.

While it bodes well that Stella limits the amount of direct test preparation that occurs in AP English Language and Composition at Violet Fields High School, the ability of standardized timed assessments to measure writing ability is a longstanding area of tension in scholarship focused on first-year writing. Brain Huot argues that a new type of writing assessment is needed. He claims that "these new procedures recognize the importance of context, rhetoric, and other characteristics integral to a specific purpose and institution. The procedures are site-based, practical, and have been developed and controlled locally" (552). Additionally, he notes that "Composition's justifiable distrust of writing assessment has given those outside of the discipline power to assess our 
students. The ability to assess is the ability to determine and control what is valuable.

Standardized forms of assessment locate the power for making decisions about students with a central authority" (564). Thus, relying on entities, such as the College Board, to assess student writing is problematic in Huot's view. More recently, Ann Del Principe and Janine Graziano-King ${ }^{42}$ have reported findings that suggest that a "Self Revised Essay" is a more accurate assessment of students enrolled in developmental writing at their institution than the traditional timed writing. Similarly, Arthur Lau cautions that "in electing to use timed writing assessment as a measure of writing ability, instructors and administrators should take care to consider the potential consequences for the culture of writing among their students and to recognize that the representation of student abilities offered by such an assessment may not be fully generalizable to other contexts" (n.p.). Moreover, he further cautions that timed writing "may be inadvertently encouraging a reductive mode of writing and elevating the importance of speed at the expense of thoughtfulness and creativity" (n.p). Thus, while Stella does limit the focus on timed standardized assessments and that is encouraging, timed writing assessments are still part of AP English Language and Composition at Violet Fields High School.

The main focus is [on] the kind of writing...that they're going to do in college. -Stella (Interview 13 March 2014)

\section{The Unit: Keys to Successful College Writing}

Above, I have looked at some of the pedagogical strategies that Stella uses in AP English Language and Composition at Violet Fields High School. I now turn to

\footnotetext{
${ }^{42}$ In "When Timing Isn't Everything: Resisting the use of Timed Tests to Assess Writing Ability," Del Principe and Graziano-King report on a small pilot study that compared student performance on "Self Revised Essays" and timed essays for a small sample of students enrolled in developmental writing courses.
} 
examining a single extensive unit included in the course. This unit focuses on Keys to Successful College Writing and in this unit, among other smaller assignments, students complete a multiple-layer Researched Argument Paper. This unit takes place at the start of the course and lasts the entire first semester.

\section{Argument}

During the Keys to Successful College Writing unit, many of the skills and concepts that are covered in first-year writing courses are addressed. For example, this unit includes material on argumentation and rhetoric, thesis statement construction, prewriting exercises, organizational patterns, and locating, evaluating and incorporating research material. These aspects are looked at more in-depth below. Not only do many of the skills and concepts overlap with the content of many first-year writing classes, there is also an emphasis on critical reading skills that have the potential to help students succeed in postsecondary education. Furthermore, the large assignment that accompanies this unit is the Researched Argument Paper and it is similar to writing assignments that students complete in first-year writing course. In what follows, I compare the material included in this unit to the material commonly included in first-year writing courses. I then move to examining the ways in which the Researched Argument Paper is similar to assignments that are included in first-year writing.

The material in the Keys to Success in College Writing unit can be separated into three parts, for the purpose of analysis. These parts include: focus on argumentation and rhetoric, writing elements, and research skills. In the first part of this unit, students learn about the historical foundation of argument, the appeals associated with Aristotle's rhetorical triangle, logical fallacies, and persuasive techniques. The unit is set-up so as to create a contrast between argument and persuasion. For example, one of the resources 
given to students is a chart that shows the different purposes, methods, usages, characteristics, endings, and organizational patterns for argument and persuasion. The chart explains that the goal of argument is to "[d]iscover the "truth,", while the goal of persuasion is to "[p]romote an opinion on a particular position that is rooted in truth" (Packet 58). It continues to point out that the technique and writer's approach for each differs. For example, it describes the general technique of arguments as "[o]ffers good reasoning and evidence to persuade an audience to accept a 'truth,", while persuasion uses a general technique that "[u]ses personal, emotional, or moral appeal to convince an audience to adopt a particular point of view" (Packet 58). In addition to the emphasis on differentiating between argument and persuasion, this unit introduces students to three different types of argument: Classical Argument, Rogerian Argument, and Toulmin Argument.

The similarities between AP English Language and Composition and first-year writing concerning the work with argumentation and rhetoric are encouraging. The material discussed above is commonly associated with first-year writing. For example, argumentation is included as a pedagogical approach in A Guide to Composition Pedagogies. In this edited collection, David Fleming argues for the importance of argument in the first-year writing classroom in "Rhetoric and Argument". Moreover, the importance of argumentation in the first-year writing course is also evidenced by other professional resources addressed to teachers of writing. One example of this is Timothy Barnett's Teaching Argument in the Composition Course published by Bedford/St. Martin's. Similarly, George Hillock's Jr. argues that “Those of us who know the needs of college writers and who are familiar with the new ACT and Sat writing samples know 
that persuasive writing will not suffice. For college and career one needs to know how to make an effective case, to make a good argument" (25). Additionally, sections on argumentation and rhetoric are commonly included in first-year writing textbooks. For example, The Purposeful Argument by Harry Phillips and Patricia Bostian, Everything's An Argument by Andrea A. Lunsford and John J. Ruszkiewicz, and Writing Arguments by John D. Ramage, John C. Bean, and June Johnson all include chapters on the foundation of argument, including the three different types of argument: Classical, Rogerian, and Toulmin. Moreover, this type of knowledge allows students to understand how the arguments that they are reading and writing work from a structural standpoint, thus allowing students to make deliberate decisions about structuring rhetorically effective arguments themselves. By focusing on argumentation, students learn to be more critical consumers of material and have a greater understanding of the ways in which arguments around them work; so that when they are tasked with creating argument, they are prepared.

\section{Rhetoric}

In addition to the focus on helping students understand how argument writing is different from persuasive writing and exposing students to three different models of argumentation, this unit also focuses on the appeals found in Aristotle's rhetorical triangle. The resources that students are given for this unit include a teacher-created handout that describes each of the appeals. For example, it describes pathos as "appealing to the audience using their emotions" (Packet 61) and provides the following examples in a bulleted list: "personal experience, figurative language (esp. metaphors/similes), analogies, playing on people's fears and insecurities, playing on people's sympathies and compassion, playing on people biases, flattery, pointing out how they will benefit, visual 
images/photographs, heart-warming/wrenching anecdotes, selecting evidence that plays on emotions" (Packet 61). Additionally, an extensive handout adapted from The AP Vertical Teams Guide for English that includes a bulleted list describing the elements of rhetoric is provided to students. The list includes categories such as purpose, audience, logical appeal, emotional appeal, and ethical appeal. For instance, it instructs students that they can appeal to emotion by the "use [of] language that involves the senses (imagery), include an emotional anecdote, use emotional description, use figurative language that evokes an emotion, include bias or prejudice, include connotative language, explore euphemisms, develop tone (attitude towards topic), experiment with informal language" (Packet 62). Additionally, "A General Summary of Aristotle's Appeals..." is taken directly from the $4^{\text {th }}$ edition of Writing Arguments by John D. Ramage and John C. Bean and describes, in a different way, ethos, pathos, and logos. For example, this resource describes pathos as:

Pathos (Emotional) means persuading by appealing to the reader's emotion. We can look at texts ranging from classic essays to contemporary advertisements to see how pathos, emotional appeals, are used to persuade. Language choice affects the audience's emotional response, and emotional appeal can effectively be used to enhance argument.

Pathos (Greek for 'suffering' or 'experience') is often associated with emotional appeal. But a better equivalent might be 'appeal to the audience's sympathies and imagination.' An appeal to pathos causes an audience not just to respond emotionally but to identify with the writer's point of view - to feel what the writer feels. In this sense, pathos evokes 
meaning implicit in the verb 'to suffer' — to feel pain

imaginatively...perhaps the most common way of conveying a pathetic appeal is through narrative or story, which can turn the abstractions of logic into something palpable and present. The values, beliefs, and understandings of the writer are implicit in the story and conveyed imaginatively to the reader. Pathos thus refers to both the emotional and the imaginative impact of the message on an audience, the power with which the writer's message moves the audience to decision or action. (Bold Original Packet 63)

A fourth resource on Aristotle's rhetorical triangle by Professor Jeanne Fahnestock from the University of Maryland is also included that uses narrative to explain the concepts. In this instance, pathos is described as:

The persuasive appeal of pathos is an appeal to an audience's sense of identity, their self-interest, their emotions. Many rhetoricians over the centuries have considered pathos the strongest of the appeals, though this view of persuasion is rarely mentioned without a lament about the power of emotion to sway the mind.

Appeals to our sense of identity and self interest exploit common biases; we naturally bend in the direction of what is advantageous to us, what serves our interests or the interests of any group we believe ourselves a part of. Even when advantage is not an issue, writers who belong to groups we identify with, or create groups we can belong to, often seem 
more compelling. We also naturally find more persuasive the speaker or writer who flatters us (especially indirectly) instead of insulting us. Thus skillful writers create a positive image in their words of the audience they are addressing, an image their actual readers can identify with. Who does not want to be the "sensible, caring person" the arguer describes?

Especially powerful are devices that create an identity between the writer and reader so that the speaker almost seems to be the audience addressing itself.

The emotions also strongly assist, perhaps sometimes determine, persuasion. If, for example, a writer wants a reader to evaluate something negatively, she or he may try to arouse the reader's anger. Or to produce action to someone's benefit (e.g. to persuade us to make a charitable donation), an arguer may work on our pity.

Direct appeals to the reader to feel an emotion (e.g. "You should be crying now") are rarely effective. Instead, creating an emotion with words usually requires recreating the scene or event that would in "real" circumstances arouse the emotion. Thus descriptions of painful or pleasant things work on the emotions. Or the arguer can work on the natural "trigger" of the emotion. If, for example, we usually feel anger at someone who, we believe, has received benefits without deserving them, then the arguer who 
wants to make us angry with someone will make a case that person was rewarded unfairly. (Packet 64-65)

Moreover, a fifth resource on Aristotle's rhetorical triangle is also included that similarly uses a narrative structure to explain the concepts ${ }^{43}$. In this instance, pathos is described as follows:

Persuasion from pathos involves engaging the readers' or listeners' emotions. Appealing to pathos does not mean that you just emote or "go off' through your writing. Not that simple. Appealing to pathos in your readers (or listeners), you establish in them a state of reception for your ideas. You can attempt to fill your readers with pity for somebody or contempt for some wrong. You can create a sense of envy or of indignation. Naturally, in order for you to establish at will any desired state of emotion in your readers, you will have to know everything you can about psychology. Maybe that's why Aristotle wrote so many books about the philosophy of human nature. In the Rhetoric itself, Aristotle advises writers at length how to create anger toward some ideal circumstance and how also to create a sense of calm in readers. He also explains principles of friendship and enmity as shared pleasure and pain. He discusses how to create in readers a sense of fear and shame and shamelessness and kindness and unkindness and pity and indignation and envy and indignation and emulation. Then he starts all over and shows how to create such feelings toward ideas in various types of human

${ }^{43}$ This is taken from Martha L. Henning's Friendly Persuasion: Classical Rhetoric-Now! 
character' of "people" of virtue and vice; those of youth, prime of life, and old age; and those of good fortune and those of bad fortune." Aristotle warns us, however: knowing (as a goodwilled writer) how to get your readers to receive your ideas by making readers "pleased and friendly" or "pained and hostile" is one thing; playing on readers' emotions in ways that make them mindless of concepts and consequences can corrupt the judgment of both individuals and the community. (Packet 66-67)

Therefore, as these five examples of different ways of explaining pathos demonstrate, students in AP English Language and Composition at Violet Fields High School are being provided with multiple explanations of ethos, pathos, and logos and have multiple resources to consult when conducting rhetorical analysis of texts. In short, these students are not just learning about Aristotle's rhetorical appeals as a-contextual tools. They are actually being asked to think about rhetorical theory.

The extensive work that students in AP English Language and Composition at Violet Fields High School complete concerning Aristotle's rhetorical appeals is also encouraging. Just as the above focus on argumentation and rhetoric, Aristotle's rhetorical triangle is a core part of many first-year writing classrooms and included in many commonly used first-year writing textbooks. For example, there are a total of four chapters in Everything's An Argument that focus on Aristotle's rhetorical triangle, and Writing Arguments also includes a chapter on this topic. This inclusion shows alignment between AP English Language and Composition and first-year writing because students are learning the same material in similar ways. Not only is Aristotle's rhetorical triangle included in AP English Language and Composition, it appears to be covered quite 
extensively and explained to students in multiple ways. This has the potential to lead to a better understanding of this concept for students.

\section{Logical Fallacies and Persuasive Techniques}

Not only do students learn about Aristotle's rhetorical triangle, logical fallacies

and persuasive techniques are also introduced in AP English Language and Composition at Violet Fields High School. Students are given a handout that includes thirty-nine fallacies and persuasive techniques that writers can use to persuade a reader ${ }^{44}$. Stella explains that a key goal is for students to recognize and identify these fallacies when they are reading and understand the effect these fallacies produce when they use them in their writing.

Similar to argumentation, rhetoric, and Aristotle's rhetorical triangle, teaching students to identify fallacies in other people's arguments and avoid them in their own arguments is a core part of many first-year writing courses. This is also reflected in many textbooks used for first-year writing. For instance, Everything's An Argument includes a chapter on Fallacies of Argument that address emotional, ethical, and logical fallacies that weaken arguments. Writing Arguments also includes an appendix devoted to explaining fallacies and the ways in which they negatively impact arguments. Similarly, A Reader's Guide to College Writing by John J. Ruszkiewicz includes a chapter on

\footnotetext{
${ }^{44}$ These fallacies include: either / or fallacy (false dilemma), equivocation, hypothesis contrary to fact, illicit process (non sequitur), faulty analogy, faulty causal generalizations, post hoc, ergo propter hoc, hasty generalization, special pleading (card stacking), appeal to force, argumentum ad hominin, argumentum ad misericordium, argumentum ad populum, bandwagon, begging the question, complex question, dicto simpliciter (unqualified generalization), labored hypothesis, red herring, syntactic ambiguity, tu quogue, name calling, testimonials, humor, glittering generalities, fear and insecurities, loaded language, celebrity endorsement, sex appeal, something for nothing, plain folks, science and statistics, comparisons and negatives, snob appeal, repetition, rhetorical questions, direct command, cuteness factor, transfer" (Packet 68-71).
} 
Critical Reading that focuses on fallacies in arguments. In short, when students have the appropriate resources, they are better able to craft strong arguments.

\section{Writing Instruction}

While argumentation and rhetoric play a large role in the Keys to Successful College Writing unit, there is also a strong focus on writing instruction. Multiple foundational elements included in a writing course are included in this unit. These include instruction on crafting a thesis statement, learning organizational patterns for different rhetorical situations, incorporating multiple types of evidence, including the voices of others in the form of quoting responsibly, and advancing in stylistic maturity. This section will explore the ways in which these aspects of writing instruction are approached in Stella's AP English Language and Composition course at Violet Fields High School.

\section{Thesis Statements}

One element of writing instruction that is thoroughly addressed in AP English Language and Composition at Violet Fields is crafting a thesis statement. The resources given to students outline twelve characteristics of a thesis statement. And, explain that "a thesis statement:

- is a one-or two-sentence condensation of the argument or analysis that is to follow

- is the topic + student's own idea/argument = main idea of the paper

- is the answer to the question your paper explores

- is relevant to the intended audience

- is debatable 
- tests your ideas by distilling them into a sentence or two

- helps you better organize and develop your argument

- is usually found at the end of the lead

- often includes a triad which establishes the organization of the paper

- requires proof (sufficient reasons and evidence)

- is the foundation of your paper used to tie all reasons and evidence together with synthesis" (Packet 13)

Through this material, students are being directed to compose argumentative thesis statements and not purpose statements. Additionally, this material clearly positions the student's idea/opinion and the topic in conversation in order to highlight the argument that the student wishes to make about the topic. This instruction also ties the crafting of the thesis statement to the rhetorical situation which the student is writing for by drawing attention to the intended audience and by focusing on the synthesis of evidence to help support the argument. While the information above relates to students what the thesis statement should do, students are also provided with material that reflects what the thesis statement should not do. For example, the resources given to students explain that "A Thesis Statement is NOT:

- a question

- a statement of the inherently obvious

- a vague or ambiguous statement

- a simple factual sentence" (Packet 13)

From this information, students are being guided to move away from genres of writing where they report information, and away from the genres associated with the writing 
portfolio when it was a requirement of the state ${ }^{45}$. Additionally, these guidelines assist in encouraging students to be specific when crafting their argument and ground their thinking with concrete ideas. Stella also provides a model for two different types of thesis statements that students will be expected to compose for different assignments while enrolled in AP English Language and Composition. In these examples, Stella explains that "[a] thesis statement has three main parts: the limited subject, the precise opinion, and the blueprint" (emphasis original Packet 13). She then provides the following examples:

- Rhetorical Analysis Example: The book Black Elk Speaks accurately represents Indian lifestyle by its attention to cultural detail, its use of Indian $\underline{\text { words, and its direct quotes from black Elk. }}$

- Argumentation Example: Because of his determination, his courage to follow his beliefs, and his unwavering sense of justice, Martin Luther king, Jr. is a symbol of American freedom.

These examples not only provide additional evidence of the modeling that is a central part of the instructional practice in AP English Language and Composition at Violet Fields High School but also allows students to visually see and separate the different parts of the thesis statement that Stella has identified as being important for the writing that they will complete in the course.

Not only are students provided with the above teacher created resource, but they are also provided with information from the Online Writing Lab from Purdue University. In this handout, students are provided with additional information that details how thesis

\footnotetext{
${ }^{45}$ When the state of Kentucky required a writing portfolio, the emphasis was on literary, transactive, and reflective writing, not on argument and analytical writing.
} 
statements for analytical, expository, and argumentative papers differ. This handout also reinforces the modeling that Stella relies upon in instruction by providing students with additional examples of each type of thesis statement. In addition to these examples, Stella provides students three additional argumentative models for thesis statements that were composed by former students of AP English Language and Composition at Violet Fields High School. All three samples provided by Stella fit within the guidelines addressed above; yet, they differ structurally so that students may see a variety of viable possible structures for crafting their own thesis statements. For example, the first student sample states that " The United States should legalize physician-assisted suicide for terminally ill patients because it preserves the freedom and autonomy of the patient, improves the patient's quality of life in the final days, and upholds the Hippocratic Oath required by all physicians" (Packet 14). This example clearly has all three parts—limited subject, precise opinion and blueprint—identified by Stella in the resources. Additionally, the structure focuses on an action that should take place and the supporting reasons. The second student sample states that "Due to the need for greater public safety and as a reaction to a changing world, the USA must now interpret the Second Amendment as a collective right meant primarily for governmental institutions" (Packet 14). In this example, the reasons for the action are presented first, and the argument is stated second. The reasons are more abstract and not as clearly defined as they are in the first student sample. The third student sample presents a two-sentence example that qualifies as it presents the argument. It states, "Although the facts remain unclear on whether meat consumption affects world hunger, there is clear evidence that shows meat production does affect the environment by contributing to deforestation, air and water pollution, and inefficient land and resource 
usage. Eating less meat, and perhaps more importantly, knowing where meat comes from, will make a difference in the negative impact that corporate agriculture has on the environment" (Packet 14). All of these examples provide students with different models to consider when they begin composing their own thesis statements.

In addition to the resources discussed in the previous paragraph, Stella provides students with a teacher created resource that presents the above information in a different way. For example, it takes a more narrative form and explains that " $[\mathrm{t}]$ he thesis statement is one of the (if not the) most important parts of your paper" (Packet 15). Additionally, although the first set of resources provide parts of thesis statements and models, at this point, Stella emphasizes that the information she is providing "offers general guidelines on writing thesis statements, but it's important to remember: thesis statements are NOT formulas, and a successful one cannot be reduced to its parts" (Packet 15). She continues to point out and provide examples of some types of thesis statements to avoid, such as "the summary thesis, proving the universal, the overly general thesis, the cliché thesis, [and] the list thesis" (Packet 16). Therefore, students have examples of successful thesis statements and examples of things to avoid when crafting thesis statements. In addition to this descriptive material addressing thesis statements, Stella provides students with two templates for crafting the types of thesis statement they will be working with most often in AP English Language and Composition ${ }^{46}$. While these templates are formulaic and have the potential to stifle student creativity, Stella explicitly points out that the template are "super-structured; yours may not look just like this—-but will have similar parts" (Packet 18). It is encouraging that the AP English Language and Composition course at Violets Fields High School spends so much time teaching students to craft solid thesis

\footnotetext{
${ }^{46}$ These documents can be found in the appendix.
} 
statements because this is a core skill that students will need when writing in

postsecondary education. Additionally, it is encouraging that this topic is covered in such a thorough manner and using resources that are also potentially used in first-year composition courses.

\section{Organization}

Attention to organizational patterns is also a central part of the writing instruction, as is signaling the reader throughout writing to guide them through the argument being presented. Stella has developed what she refers to as THE PATTERN to assist students in organizing paragraphs. THE PATTERN requires students provide a reason that supports their argument in the topic season that is supported by evidence and followed by synthesis. Stella notes that "[e]ach element must be tied directly back to the thesis statement; therefore, without a concise, specific thesis statement the rest of the essay will fall apart” (Packet 21). In addition to THE PATTERN for organizing paragraphs, students also receive instruction focused on the 3.5 essay. For example, students are provided with resources that detail the structure of the 3.5 essay format that even goes so far as to tell students what piece/type of information should be included in each sentence of each paragraph. Students are also provided with an empty outline as a template and an organizational sheet ${ }^{47}$. Even though the Keys to Successful College Writing unit includes this focus on the 3.5 essay, Stella explains that it is used as a jumping off point for more sophisticated writing structures and students are encouraged to very quickly master the 3.5 format and move on to organizational patterns that fit the needs of their specific rhetorical situation. However, students in AP English Language and Composition are encouraged to use the 3.5 essay format on timed assessments, such as the state on-

\footnotetext{
47 These documents can be found in the appendix.
} 
demand writing assessment and in composing responses for the three essay questions on the AP English Language and Composition exam. Stella explains, "there are some things like the 3.5 essay that is the most basic [and I tell them] you have to go beyond that. They are supposed to go beyond the basic format because they want to be more effective and sophisticated than the basic" (Interview 13 March 2014). Furthermore, students are also provided with online resources from college writing centers that focus on organizing an argumentative research paper. These include resources from the OWL at Purdue University, University of Washington, and University of Houston. It bodes well that students in AP English Language and Composition at Violet Fields High School are being taught foundational elements of organization, being pushed to expand from basic modes and formulas to more sophisticated organizational choices, and being exposed to college-level resources, especially since the teacher views this course as an alternative way of fulfilling the first-year writing requirement.

\section{Using Evidence}

Moreover, material is also presented in AP English Language and Composition that allows students to explore the different types of evidence that they might use when supporting arguments. Students are provided with a resource that describes the five types of evidence that they may use to support a claim. These include: expert opinion, facts and statistics, anecdotes, personal experience, and values. In conjunction with finding evidence there is also a focus on developing print and electronic research skills. Stella explains that her students actually have the opportunity to visit the university library as a field trip in order to gather evidence to support the arguments that they are making in their Researched Argument Papers. This allows students the chance to research at an actual university library and use the same resources that are available to first-year college 
students. In addition to the university library field trip, students also have access to the school's extensive library, databases that the school subscribes to, and databases provided through the Kentucky Virtual Library. A key concern that arises when students fulfill first-year writing credit through alternative means, such as AP English course credit, is that they are missing the opportunity to be taught how to use college-level academic research resources. However, this concern is greatly reduced at Violet Fields High School because students have the opportunity to spend time using the resources at and provided by the local university. It is very encouraging that students in AP English Language and Composition are being afforded the opportunity to work at a university library and with college level resources as they complete a course that is equivalent to first-year composition.

\section{Incorporating Sources}

Not only is selecting evidence an important part of the AP English Language and Composition course, but directing students how to incorporate the voices of others in a responsible manner also plays a role. For this task, Stella relies on resources commonly used in first-year college writing classrooms. She provides students with several templates included in They Say / I Say: The Moves that Matter in Academic Writing by Gerald Graff and Cathy Birkenstein. This material allows students a safe format for learning to incorporate the voices of others within their texts and provides models to show students how they might frame quotations, paraphrases, and summaries for both agreeing and disagreeing with sources. In addition to providing students with the opportunity to learn how to successfully incorporate the words of others in their research, Stella's AP English Language and Composition course provides students with 
information on the correct citation practices for MLA and resources for avoiding plagiarism.

While is it encouraging that students are using resources commonly used in firstyear writing courses, such as They Say / I Say, it is potentially troubling the ways in which plagiarism is addressed because Violet Fields High School relies on the use of Turnitin.com to detect plagiarism cases. The use of plagiarism detection software is generally not looked on favorably by scholars in Rhetoric and Composition. As early as 1995, Rebecca Moore Howard argues that composition scholars need a new approach to plagiarism and suggests an alternative policy. As she explains, "This new policy does not endorse a "more lenient attitude" toward plagiarism; rather, it suggests an enlarged range of definitions and motivations for plagiarism, which in turn enlarges the range of acceptable responses" $(789)^{48}$. Additionally, many composition programs have issued statements against the use of plagiarism detection software. For example, the University of Louisville's composition program explains to instructors the principles behind the decision not to use this type of software.

- We regard the teaching of writing with research, including citation practices, as a rhetorical act.

- The use of such a service for student writers begins from a presumption of guilt.

- The best deterrents to plagiarism are well-designed writing assignments that are distinctive to course material and involve effective writing pedagogy.

\footnotetext{
${ }^{48}$ For further information about responses to plagiarism, see Price, Margaret. 'Beyond 'Gotcha!': Situating Plagiarism in Policy and Pedagogy.” College Composition and Communication 54.1 (2002): 88-115. Print. Or Valentine, Kathryn. "Plagiarism as Literacy Practice: Recognizing and Rethinking Ethical Binaries." College Composition and Communication 58.1 (2006): 89-109. Print.
} 
- Research on plagiarism detection software such as SafeAssign and Turnitin indicates that such software can produce many inaccurate reports, finding plagiarism where it doesn't exist and missing plagiarism that does.

- The results of plagiarism detection software make no distinction between plagiarism as a form of intentional cheating and students who are making mistakes in working with unfamiliar conventions of academic writing. Because scholarship in Rhetoric and Composition discourages the use of plagiarism detection software and individual composition programs prohibit its use for the reasons outlined above, it is troubling that students enrolled in AP English Language and Composition are required to use this software and provide the teacher with a report concerning the plagiarism found in the document ${ }^{49}$. The use of this software in a class, such as AP English Language and Composition, that markets itself as a precollege credit for writing alternative and claims to prepare students for the types of writing that they will experience in college is out of alignment with current scholarship and practices concerning plagiarism.

\section{The Researched Argument Paper and First-Year Composition Outcomes}

While students are completing the Keys to Successful College Writing unit, they are also working on completing what Stella has named the Researched Argument Paper. As referenced in chapter four, this is a multi-layered project that requires students to develop research questions, project proposals, conduct research at an academic library, compose an extensive annotated bibliography, compose a summary of sides, explain the position that the writer is taking on the topic, draft a 8-10 page argument paper, revise the

\footnotetext{
${ }^{49}$ Although this software is not used in the Composition program, it is commonly used in other courses at the University of Louisville.
} 
paper, and compose a reflection on the process of completing the project. While students are completing this project, they are also participating in peer workshops, conferencing with Stella, and revising their projects based on the information that they find throughout the research process.

It is encouraging that this assignment is very similar to, and even perhaps more extensive than, assignments that students in first-year composition complete. For example, this project meets the outcomes for English 102 at the University of Louisville. When considering the outcomes for Rhetorical Knowledge, the Researched Argument Paper presents the opportunity to meet all five outcomes. The Position Paper that students in AP English Language and Composition complete allows students to "demonstrate rhetorical purpose by creating a position relative to their research. For instance, the assignment sheet explains that, at this point in the project, the "task is to declare where you stand on this issue and why (i.e. your argument)... Write four-to-fivepage paper (typed) stating your position supported by reasons and specific evidence" (Researched Argument Paper Assignment 2). Moreover, this assignment also calls on students to "analyze the needs of the audience and requirements of the assignment or task" (UL English 102 Outcomes) throughout all parts of the assignment because students must take into account the generic conventions for the different composing tasks and meet the differing needs of their intended audience for each task. For example, students in AP English Language and Composition must adjust the level of formality in their writing when they are brainstorming and planning for the first component of the assignment — the Idea Dump —or writing the final, and more formal, academic argument. Similarly, students must "demonstrate knowledge of genres employed in writing with 
research" (UL English 102 Outcomes) when they are composing in different genres. For example, students will not compose the Idea Dump in the same way that they compose the Annotated Bibliography. Nor will students approach the Summary of Sides in the same manner as they will the Final Paper.

In addition to meeting the outcomes outlined for Rhetorical Knowledge for English 102 at the University of Louisville, students enrolled in AP English Language and Composition at Violet Fields High School meet the outcomes for Critical Thinking and Reading. For example, as students complete the Annotated Bibliography, Summary of Sides, and Position Paper, they are "identif[ying] rhetorical strategies and summarize[ing] main ideas of outside sources" (UL English 102 Outcomes) because these assignments call for students to incorporate outside sources in a rhetorically effective manner. Moreover, in completing the Summary of Sides, Position Paper, and Final Paper, students are "plac[ing] sources in context with other research" and "represent[ing] and respond[ing] to multiple points of view in research" (UL English 102 Outcomes). For example, the assignment sheet explains that students should "be sure... [they] understand what the various positions are and why certain groups or persons advocate them" (1). Students are engaging in a conversation with others through their writing when they respond to what others have said and incorporate and expand on these prior ideas.

Furthermore, students in AP English Language and Composition at Violet Fields High School are also meeting the outcomes outlined for Processes for English 102 at the University of Louisville. Students are "identif[ing] a research question" in the Idea Dump portion of the assignment. Furthermore, they are also "develop[ing] a research strategy" 
when they are proposing their idea in the Idea Dump and when they go to the library at the University of Louisville. Additionally, the Annotated Bibliography requires students to "identif[y] and evaluate sources" to determine which sources may prove valuable to their individual project. Students are also "using[ing] research sources to discover and focus a thesis" as they complete the Researched Argument Assignment.

One of my goals is to make my students ready to write multiple 4-to-5-page papers in a week at the same time they are learning new content and studying for tests. I want their early experience in college to seem relatively easy. Why not struggle now in high school when you have more support from your teachers, your school, your friends and your family.

$\sim$ Stella (Philosophy 2)

\section{Conclusions}

AP English Language and Composition at Violet Fields High School is an impressive course that mirrors first-year composition courses. Not only does Stella's AP English Language and Composition course at Violet Fields High School meet the outcomes outlined by the College Board for the course, it also arguably surpasses many first-year college writing courses in terms of complexity, rigor, and the amount of writing that students are producing. It is important that this alignment exists because the purpose of AP English Language and Composition at this location is to expose students to academic writing and serve as a precollege credit for writing alternative. Therefore, for many of the students enrolled in Stella's AP English Language and Composition course at Violet Fields High School, this course serves as their first-year writing experience.

Although AP English Language and Composition at Violet Fields High School is impressive, the unique circumstances of this location and the type of student population 
that attends, make this, as Stella tells us at the beginning of the chapter, "the ideal world" (Interview 13 March 2014). As Stella acknowledges, the course that she is able to deliver at Violet Fields High School would be extremely difficult to replicate at a location without the resources available at Violet Fields High School and with a different population of students. The highly affluent and privileged students who attend Violet Fields High School and the resources available allow for AP English Language and Composition to function at a level that arguably exceeds the common first-year writing course.

While the enactment of AP English Language and Composition at Violet Fields High School is noteworthy, it is not without limitations. One such limitation is the large class size of the AP English Language and Composition course. While the National Council of Teachers of English recommend that writing courses, like this one, have enrollments of 20 students, the AP English Language and Composition course at Violet Fields High School typically has 25-30 students in each section. This enrollment number is consistent with other courses offered at Violet Fields High School and within the district. The large class size is potentially troubling because it potentially does not allow the instructor to provide students with individualized writing instruction and restricts the number and length of conferences that the instructor is able to hold with individual students. In addition to the large class sizes, the use of plagiarism detection software is also potentially troubling, as it does not align with practices of many first-year writing programs.

Although the rigor, challenge, and complexity of AP English Language and Composition at Violet Fields High School are remarkable, perhaps the greatest potential 
limitation of this course also lies in its rigor, challenge, and complexity. Recently, attention has been brought to the fact that too much rigor and challenge negatively impacts students and their preparation for college because of the stress that students can potentially experience with the pressure to succeed in such courses. In examining the experiences of AP and International Baccalaureate students, Regan Clark Foust, Holly Hertberg-Davis, and Carolyn M. Callahan found that students identified some disadvantages with their participation in advanced coursework. They explain that "Three themes emerged concerning disadvantages: (a) the perception of unflattering stereotypes assigned to AP and IB students, (b) the heavy workload, and (c) stress and fatigue" (295). Specifically, they found that "Not only did the workload in AP and IB courses limit some students' ability to participate in extracurricular activities, many reported that they needed to use every spare moment—during lunch, during non-AP or non-IB classes, and outside of school - to finish their work" (301). Moreover, Foust et al also found that "Students reported that the workload, pace and level of challenge, and the grades they received in AP and IB courses had an impact on their emotional state" (301). Therefore, because many students at Violet Fields High School are taking multiple AP courses and participating in other activities, it is important to take into consideration and put measures into place that safeguard the wellbeing of students striving for excellence through advanced coursework.

In short, this case study shows that AP English Language and Composition at Violet Fields High School is effectively serving as a site of first-year college writing for the students enrolled. Students entering postsecondary education after taking this course have experienced writing instruction that is equal to that found in on-campus first-year 
composition courses. Students exiting this course have had extensive experiences crafting academic arguments and researching at a college library. However, the location is especially unique and the course described in this case study would be difficult to enact at a different location with a different student population. 


\section{CHAPTER 6: TRADITIONAL CONSTRUCTIONS OF AP ENGLISH LANGUAGE AND COMPOSITION: THE STORY OF ONE TEACHER'S INSTRUCTIONAL APPROACH}

Because there are multiple ways in which AP English Language and Composition can be enacted and continue to meet the outcomes and expectations outlined by the College Board, investigating specific practices at individual locations provides the most accurate indication of the type and focus of instructional practices. Even though AP English Language and Composition teachers are guided by boundary objects, such as the outcome statement for the course, Teacher's Guide, and structure and content of the AP English Language and Composition exam, the way in which an individual teacher incorporates other state and district curricular requirements influences the content and focus of the course. This chapter presents a case study that reflects the literary focus found in some secondary English courses and the pressures on the teacher to merge district curriculum focusing on American Literature with the requirements set by the College Board for AP English Language and Composition. Moreover, the AP English Language and Composition course that is enacted at any particular location is heavily influenced by the school's history, experiences of the teacher, and background and goals that the students bring with them into the classroom. This chapter examines the ways in which AP English Language and Composition is enacted at a successful school with adequate resources and achievement-driven students in order to demonstrate the range of 
experiences found in the instructional practices of AP English Language and Composition.

I think it prepares you to pass the test but I don't know if it actually prepares you for college.

〜Jill (Interview 27 May 2014)

\section{AP English Language and Composition at Blue Meadows High School}

Aligning with traditional notions of AP coursework, Blue Meadows High School encourages college ready students to enroll in AP English Language and Composition. However, any student that wishes to enroll is permitted. William ${ }^{50}$, the AP English Language and Composition teacher at Blue Meadows High School, explains that he wishes that the counselors would be more direct in describing the rigors of AP English Language and Composition to students during their sophomore year because many students that are unprepared for the demanding workload and rigorous pace are ill prepared to complete the course successfully. Therefore, after students have indicated that they want to enroll in AP English Language and Composition, William confers with the sophomore English teachers at Blue Meadows High School to identify students that would be better placed in another English course offering. William explains that students lacking preparation "would be better placed in a comprehensive English class with more ACT prep because this class has very little ACT prep and is focused on writing" (Interview 11 March 2014). Here William is possibly implicitly acknowledging that students best served by AP English Language and Composition at Blue Meadows High

\footnotetext{
${ }^{50}$ For more information about William see chapter two.
} 
School are already meeting college readiness benchmarks as measured by the ACT, and therefore additional ACT preparation would not be necessary for these students.

In this chapter I explore the practices of William's AP English Language and Composition course at Blue Meadows High School. First, the chapter looks at the instructional approaches that William employs using observation data, material from follow-up conversations with William, and student survey and interview data. This discussion shows the course is focused on exposing students to specific literary traditions and places a heavy emphasis on preparing students to be successful on the AP English Language and Composition exam. While the other AP English Language and Composition courses included in this study also incorporate literature and test preparation, they include and emphasize these aspects through writing instruction that asks students to move beyond the rhetorical situation provided by the AP English Language and Composition exam. However, at Blue Meadows High School, the ways in which this particular course is structured focuses on these in isolation from writing instruction that focuses on rhetorical situations outside of composing essays for the AP English Language and Composition exam and arguably in place of writing instruction. Following an examination of the instructional approaches, this chapter investigates student perceptions about the course and its relationship to first-year composition. The chapter ends by discussing the implications for students entering postsecondary institutions after completing this type of AP English Language and Composition course.

\section{We did a lot of grammar and language oriented things.}

〜Faith (Interview 27 May 2014) 


\section{Instructional Practices}

\section{Warm-Up}

One aspect of AP English Language and Composition at Blue Meadows High School is the extensive daily warm-up exercise that students complete at the start of each class. The warm-up exercise is comprised of four parts: a vocabulary/grammar/usage multiple choice question, word of the day, quote of the day, and big question. While the theme of the big question relates to the content of the day's class, the other parts of the warm-up directly relate to test preparation for the ACT and the AP English Language and Composition exam. Students arrive in class and immediately start copying the vocabulary/grammar/usage multiple choice question from the board. Once class begins and all students have copied the question and answered it individually, William has a student pull a name out of the jar. The name that is pulled from the jar is the student that is selected to answer the question. The student is given one chance to answer correctly and explain why the answer they choose is the correct response. If the selected student answers incorrectly, another name is pulled from the jar and this continues until the correct answer is selected. After the correct answer is selected, William explains why the other choices are incorrect. He invites students to assist in this explanation. Table 10 provides example vocabulary/grammar/usage multiple choice questions. While it is encouraging that students are being exposed to sophisticated stylistic structures and additional vocabulary words through this activity, it is troubling that the sentences and vocabulary words are decontextualized from the course. From a writing instruction standpoint, students would most likely experience greater benefit from this type of exercise if they were working on revising their own compositions for greater stylistic 
maturity or working with sentences composed by past students of AP English Language and Composition.

Table 10: Warm-Up: Vocabulary/Grammar/Usage Question Examples

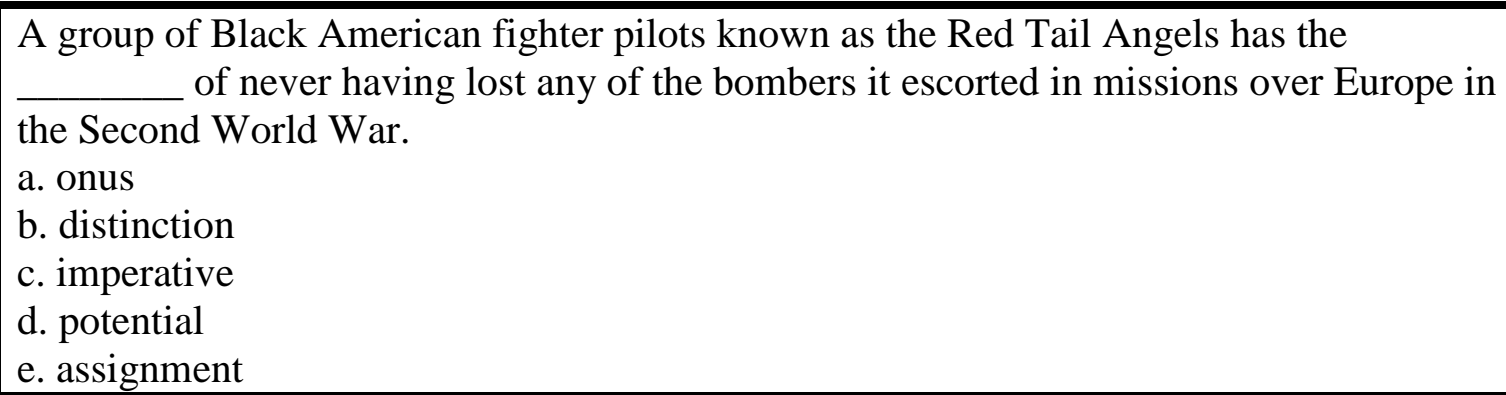
of never having lost any of the bombers it escorted in missions over Europe in the Second World War.

a. onus

b. distinction

c. imperative

d. potential

e. assignment

Bolstered by his unflagging determination and physical preparation, Tom

Whittaker became the first amputee to successfully climb to the summit of Mount Everest.
a. fortuitous
b. assiduous
c. heedless
d. expeditious
e. pedantic

Currently rising temperatures in the Artic and Antarctic are of a still warmer

world that could result from an excess of atmospheric carbon dioxide produced by the burning of oil, gas, and coal.
a. polarities
b. harbingers
c. vestiges
d. counter examples
e. aftereffects

In her review of a recent novel, the book reviewer insisted on discussing details of the author's life, in open consideration of biographical matters.
a. fixation on
b. defiance of
c. deference to
d. incitement of
e. collusion with

The purpose of this portion of the warm-up is to help students expand their vocabulary and practice identifying grammatical structures, with the ultimate goal that students will incorporate these into their writing. These skills are important for students enrolled in this course because a problem that arises on both the ACT and AP English 
Language and Composition exam is that students are unfamiliar with the vocabulary used in reading passages and questions and, as a result, are unable to answer questions correctly. In order to assist students in expanding their vocabularies, they are introduced to new vocabulary words through exercises testing grammar and usage rules each class and are tested over their retention of these every couple of weeks. William explains that he feels student knowledge of "vocab is a problem and it is getting worse because, with the Common Core, they are reading less and less in school. And, when they write, they abbreviate and use hashtags" (Observation 19 March 2014). However, recent studies challenge the idea that student writing errors are increasing. For example, Andrea A. Lunsford and Karen J. Lunsford's 2008 article ““"Mistakes Are a Fact of Life”: A National Comparative Study" finds "that papers are longer, employ different genres, and contain new error patterns" (781) but do not contain more errors than student papers of the past. Moreover, the focus on decontextualized grammar instruction observed in AP English Language and Composition at Blue Meadows High School also goes against research in Rhetoric and Composition concerning the teaching of grammar. James D. Williams notes that "[t]he conclusion that grammar instruction fails to improve writing is not new" (314), as he sites work in the field dating back to $1963^{51}$. Additionally, research on the increased use of text messaging and other forms of digital communication does not support the argument that students are negatively affected by these types of cultural shifts in communication. For example, David Crystal ${ }^{52}$ argues that

\footnotetext{
${ }^{51}$ Specifically, he cites: Research in Written Composition by Richard Braddock, Richard Lloyd-Jones and Lowell A. Schoer; Research on Written Composition: New Directions for Teaching by George Hillocks Jr.; Grammar and the Teaching of Writing: limits and Possibilities by Rei R. Noguchi.

${ }^{52}$ David Crystal is also the author of Txting: the Gr8 Db8.
} 
The whole point of style is to suit a particular technology where space is at a premium; and when that constraint is dropped, abbreviate language no longer has any purpose. Its 'cool' associations amongst young...people will allow some of its idiosyncrasy to achieve a use elsewhere, and there are occasional reports of Textspeak creeping into other forms of writing, such as school essays. But these are minor trends, part of the novelty of the medium. They can be controlled as part of the task of developing in children a sense of linguistic appropriateness. (82)

Similarly, Donita Massengill Shaw, Carolyn Carlson, and Mickey Waxman conclude from their study on the connection between text messaging and spelling mistakes that "Despite the increase in recent years in the number of news briefs that have recently been published regarding the correlation between texting/instant messaging abbreviations and students' written ability, we cannot conclude at this time that the implementation of technological writing reduces correct spelling with pen and paper” (61). Therefore, perhaps William is buying into popular negative perceptions that circulate concerning the influence that digital communication has on student writing ${ }^{53}$.

Similar to the previous portion of the warm-up, the next part also focuses on vocabulary expansion and culminates in students being tested over the accumulation of words multiple times throughout the semester. In the next part of the warm-up exercise William introduces the word of the day. Students copy the word into their notebooks. Another name is drawn from the jar and that student is asked to use the word in a sentence. William also uses the word in multiple sentences and asks the class to join in

\footnotetext{
${ }^{53}$ For examples of discussions of the negative influences of digital communication see: Bridget Carey's "The Rise of Text, Instant Messaging Slips into Schoolwork"; Laura Diamond's "Instant Message Shortcuts Creep into Homework"; USA Today's “Texting, Testing Destroy Kids' Writing Style”.
} 
and make sentences using the word. Table 11 provides examples of words and definitions included in this exercise.

Table 11: Warm-Up: Word of the Day Examples

truncate $(\mathrm{v})$-to cut short

erudite (adj) -wise

ogle (v) -stare at in an obvious manner

reciprocate $(\mathrm{v})$-pay back

subterfuge $(\mathrm{n})$-trickery

Again, while it is positive that William includes instruction to address an area

where students struggle, the way in which the words are not related to the context of the course is potentially problematic. Studies focusing on vocabulary development encourage the use of more embedded vocabulary instruction. For example, Donna C. Kester Phillips, Chandra J. Foote and Laurie Harper point out that "definition copying" "fail[s] to develop relational knowledge that is necessary for true understanding of the concepts represented by the vocabulary words (Blachowicz \& Fisher, 1996)" (63). Moreover, they also point out that definition copying "utilizes the lowest levels of cognitive processing from the perspective of Benjamin Bloom's (1956) Taxonomy of thinking and are therefore, highly unlikely to lead to true understanding, learning, or transfer to new situations" (63). In short, it may better serve students to locate words within their own reading that are unfamiliar and use these words to begin expanding their vocabularies in a contextualized manner, as Phillips et al recommend.

While these two exercises can be linked to preparing students for standardized assessments, the next section of the warm-up focuses on strengthening students' argumentative skills by focusing on analysis and the identification of fallacies that weaken arguments. After students complete the vocabulary/grammar/usage multiple choice question and review the word of the day, William introduces the quote of the day. 
Students copy the quote of the day into their notebooks and another student name is selected from the jar. This student is supposed to explain what the quote argues and identify one fallacy present within the quote. Table 12 provides examples of quotes included in this part of the warm-up exercise.

Table 12: Warm-Up Quote of the Day Examples

To live is the rarest thing in the world. Most people exist, that is all.

Oscar Wilde

People demand freedom of speech as a compensation for the freedom of thought which they seldom use.

$\sim$ Soren Kierkegaard

Our real blessings often appear to us in the shape of pains, losses and disappointments but let us have patience and we soon shall see them in their proper figure.

Joseph Addison

A creative man is motivated by the desire to achieve, not the desire to beat others. $\sim$ Ayn Rand

Great minds have purposes, others have wishes.

$\sim$ Washington Irving

Although it bodes well that students frequently practice analyzing brief arguments and identifying flaws that weaken arguments, it is troubling that this most often occurs verbally and not though written assignments. Moreover, it is also troubling that students are not conducting extended written analyses of longer and more complex arguments. Yet, students do select a quote and construct a response to the writer's argument every couple of weeks in a 500 word blog post. However, pedagogically, William links this writing activity to preparing students to compose one of the essay questions included on the AP English Language and Composition exam.

Many possibilities exist to explain why William feels this is the most effective method of teaching the course. There is a strong possibility that William focuses so intensely on test preparation because high performance is expected from students on the AP English Language and Composition exam from parents, the school, the district, and 
the state. Yet, while the focus on test preparation helps students perform well on the exam, it does not necessarily prepare students for college writing experiences outside of timed writing responses. Focusing on preparing students for the exam teaches students how to write responses for the exam, not how to compose process-based out of class research assignments. First-year composition seeks to prepare students to write in a variety of rhetorical situations that cannot be captured through timed writing scenarios. Because of the sensitivity that first-year writing shows to specific rhetorical contexts, scholars in rhetoric and composition, such as Brian Huot, Ann Del Principe and Janine Graziano-King, and Kathleen Blake Yancey argue against the use of timed writing as an authentic measure of student writing. Although knowing how to respond to an essay prompt in a timed setting will help students when they enter postsecondary courses that require exam essays, it does not prepare students to plan and execute a long-term written assignment that requires stylistic maturity and responsiveness to varied rhetorical situations. Moreover, focusing on test preparation does not allow students the opportunity to develop the dispositions identified in the Framework for Success in Postsecondary Writing ${ }^{54}$ because the dispositions identified in the Framework call on students to operate outside of constraints imposed by timed assessments and explore authentic real-world issues. It is difficult for students to develop curiosity, openness, engagement, and creativity when they are focused on navigating the structure of the exam and ways to respond that have been noted to increase scores. In short, while William's approach is influenced by many factors and pressures, it does not present students with an experience similar to first-year writing.

\footnotetext{
${ }^{54}$ See chapters three and four for further discussion concerning the Framework for Success in Postsecondary Writing.
} 
The warm-up also includes students copying down what William refers to as the "Big Question" for the day. This is the question that guides class activities and students should be able to successfully answer the question at the end of the class session. Table 13 provides examples of "Big Questions" used to focus lessons during my observational period.

\section{Table 13: Warm-Up Big Question Examples}

Which characters or conflicts have you most intrigued?

What examples of Romanticism and Realism did you find in today's viewing? Think character interactions, setting, plot, etc. [Neal, Charlie, Know, Todd, Mr. Keating]

What is giving you the most trouble in answering the multiple choice questions on the AP practice questions?

How did you select the rhetorical devices about which you wrote your practice analysis essay?

What conflict do you expect to encounter in The Great Gatsby?

Why did you miss the questions you missed, and what were the strengths and weaknesses of the synthesis exemplars?

While the course is clearly organized with each class session having a particular end target and this is clearly communicated to students so that they can assess as to whether they have successfully mastered the material for a particular class session, as the above "Big Questions" indicate, many class sessions are focused on humanities based topics and test preparation that would not be included in first-year writing classrooms, especially ones focused on argumentative academic writing. In short, the "Big Questions" do not indicate that this course employs composition pedagogies that are equivalent to the pedagogies found in first-year writing courses. For example, while students are composing different types of arguments in response to essay questions on the AP English Language and Composition exam, the writing instruction is not similar to an argumentative approach to first-year writing, as described by David Fleming in "Rhetoric and Argument." Moreover, students are also not exploring genre in explicit ways so there 
is very little connection between this course and genre approach to first-year writing, as described by Amy J. Devitt. Students are also not being exposed to a research writing curriculum, as described by Rebecca Moore Howard and Sandra Jamieson, because they are not researching. When students write about the literature studied, William's approach comes closest to a literature approach to first-year writing. Yet, students are not composing formal arguments about the texts that they read or conducting extended written analyses. In short, when considering William's approach in light of current composition pedagogies $^{55}$, the lack of writing instruction outside of preparation for the AP English Language and Composition exam does not align with common practices. Therefore, the students are not receiving an experience that is similar to first-year writing, even though the majority of students indicate that they are taking this course in an attempt to bypass first-year writing when they enter postsecondary education.

I now turn to exploring three aspects addressed in the "Big Questions" for AP English Language and Composition at Blue Meadows High School. These include Romanticism and Realism, The Great Gatsby, and the ways in which test preparation for the AP English Language and Composition exam is included in the course. Although, before I move on to this examination, I would like to note that the AP English Language and Composition course at Blue Meadows High School is responding to a variety of pressures because William feels he must continue to include state and district curriculum focusing on literature, even though this inclusion is in tension with first-year writing courses. This leads the course, at this particular location, to resemble a more traditional construction of high school English where literature occupies a central role. While

\footnotetext{
${ }^{55}$ For more information about current pedagogical approaches commonly used in first-year writing courses see A Guide to Composition Pedagogies edited by Gary Tate, Amy Rupiper Taggart, Kurt Schick, and H. Brooke Hessler.
} 
literature was included in the other AP English Language and Composition courses participating in this project, its inclusion at Blue Meadows High School differs because of the amount of instructional time devoted to it and the fact that the teaching of literature is divorced from the practice of having students construct formal written arguments about the literary works that they read.

We should have learned a lot more about rhetoric and not that we didn't [but] I don't think we went in-depth because we did a lot of things off to the side that really didn't help us get ready for the test.

〜Jill (Interview 27 May 2014)

\section{Romanticism and Realism}

The students in AP English Language and Composition at Blue Meadows High School learn about Romanticism and Realism through film. At the start of this lesson, William tells that class that there will be "no test prep today" (Observation 3/11/2014) because they will consider the characteristics of Romanticism and Realism through the characters and events in The Dead Poet's Society. Before William starts the film ${ }^{56}$, the students engage in a brief writing exercise. First, students are asked to write for five minutes, consulting their notes on Romanticism and Realism when needed, considering the examples of Romanticism and Realism that they have witnessed thus far in the film. Students then share their examples and William asks them what criteria they are using to base their judgments. The students make miniature verbal arguments about what characters, events, and settings were aligned with which literary tradition and supporting these arguments with points from the film. Moreover, during this class session students

\footnotetext{
${ }^{56}$ The students had started watching the film during the previous class session.
} 
also complete a second short writing assignment that asked them to consider the following quotes:

Show me the heart unfettered by foolish dreams. And, I'll show you a happy man.

\section{Tennyson}

But only in their dreams can men be truly free. It was always thus and always thus will be.

\section{Keating}

Once students have thought about the meaning of each quote, they are instructed to "argue for and/or against each of these points of view" and choose a side to identify with (Observation 11 March 2014). The students have three minutes to complete this writing activity. This writing activity is followed by another short writing activity that focuses on conflict. For the next part students are asked to take three minutes and "Identify as many conflicts as you can identify thus far in the movie" and "predict any potential conflicts that have not yet surfaced in the movie" (Observation 11 March 2014). Students are then asked to complete another three minute writing activity where that look at the following three quotes:

- "Most men live lives of quiet desperation" (Thoreau).

- "Dare to strike out and find new ground" (Mr. Keating).

- "I sound my barbaric YAWP over rooftops of the world" (Whitman). After students complete this activity, William asks students to randomly share. Students are allowed to either read what they have written or summarize their response for these 
three short writing activities. Many of the students provide a summary instead of reading what they composed.

While it is useful that the students are writing and being asked to think reflectively, this type of writing, which students seem to do quite a bit in AP English Language and Composition at Blue Meadows High School, is not the academic and argumentative writing required in many first-year writing courses. Moreover, students are only spending a few moments on each writing task and not being allowed the time to construct thorough responses. It is also problematic that during the discussion of student responses William pushed for students to connect their thoughts to school and other readings that they had completed. The text connections, while important, are only one aspect of critical thinking and encourage students to stay within the world around them and not consider the larger rhetorical situations for which the excerpts and quotations that they are responding to come from. In short, these short in-class writing assignments are more aligned with journaling and/or reflecting than they are with the academic argumentative researched based writing that students are asked to complete in first-year writing courses at postsecondary institutions.

Well this class was more of a literature class.

-Brandon (Interview 27 May 2014)

This class focuses more on literature.

Ruth (Interview 27 May 2014)

\section{Novel Instruction}

In addition to focusing on literary traditions, the curriculum in AP English Language and Composition at Blue Meadows High School focuses on fiction texts from 
the American tradition. During my period of observation, students read The Great Gatsby. In what follows, I examine the practices associated with this unit. While students complete the actual reading of the novel outside of class over a three week period, William spent class time introducing the novel and author using documentaries about The Great Gatsby and F. Scott Fitzgerald. The first documentary focuses on presenting the biography of F. Scott Fitzgerald. While the students watch this film, they complete a guided viewing sheet ${ }^{57}$. After the film concludes, William asks students if there are any blanks that they missed and the students share answers for those question. After learning about F. Scott Fitzgerald through film, the students then view the Great Books documentary for The Great Gatsby. William explains that this is an instructional strategy that he frequently employs when beginning a novel unit and that some students are upset because the Great Books documentaries give away the story. However, he feels that students are able to be critical readers if they approach the text with knowledge because then they can read for more than plot summary. As students watch this film, they complete another guided viewing worksheet ${ }^{58}$. After this class session, students read The Great Gatsby for homework over the next three weeks. While they are reading, they are assigned a Moments Journal. For this assignment, students select three quotes from each chapter and relate their chosen quotes to themes, symbolism, character, or conflict. For a final assessment of the novel, William typically gives a test that pulls images from the novel and asks students to explain the significance of the image in three lines. However, the students were asking that this assessment be replaced with a Socratic circle and William was leaning towards that option for this final assessment.

\footnotetext{
57 This activity can be found in the appendix.

${ }^{58}$ This activity can also be found in the appendix.
} 
While exposure to classic works of literature is an important part of a humanities education, this type of instruction and accompanying work is not typically seen in firstyear writing classrooms. The types of writing that students are completing for this unit, similar to the writing they completed for the Romanticism and Realism unit, is focused on short reflective passages where they make connections between the text and other things they have read or their personal experiences. Students are not being asked to create an argument and support that argument with evidence from the text. Additionally, an opportunity for research is being missed because students could be finding and locating historical material about F. Scott Fitzgerald and reception to The Great Gatsby through formulating research questions and conducting small research projects. This type of project could easily be undertaken with the resources available at Blue Meadows High School and within the same amount of time that was spent viewing documentaries where students passively recorded directed notes. For example, this school has portable class sets of laptop computers and access to Kentucky Virtual Library, in addition to book resources in the school's library. Furthermore, as mentioned above, to more align with a first-year writing course, the assessment for this unit could be replaced with a formal writing assignment where students are asked to compose an argument about the text and support that argument with points from the text. While some of this function is performed by a Socratic circle, if William chooses to go in that direction for the final assessment, students are missing out on an opportunity to practice writing arguments and locating evidence. Moreover, a Socratic circle would eliminate the little bit of writing that students are completing. The issue lies not within the intellectual work accomplished by the pedagogical methods employed by William but in the fact that AP English Language 
and Composition is acting as a site of first-year writing for many of these students and they are not experiencing writing instruction comparable to that of first-year writing because they are not constructing and sustaining written arguments.

The actual AP test was easier than the practice tests.

〜Karen (Interview 27 May 2014)

We mostly just focused on how to pass the AP test. So, I learned how to do those types of essays and answer those types of questions.

〜Ruth (Interview 27 May 2014)

\section{Test Preparation}

Test preparation for the AP English Language and Composition exam is also an essential part of the AP English Language and Composition course at Blue Meadows High School. Class sessions frequently focus on students completing practice multiple choice questions and released essay prompts for the exam, discussing their responses in small groups, and reviewing sample responses released by the College Board. In this section, I examine these practices.

During the first class observation, students were working in groups to select answers to a series of practice multiple choice questions and reviewing responses to the 2010 AP English Language and Composition Free-Response Question 2 (Form A) that they had completed for homework the night before. William started this class session by reminding students that they only need to get $50 \%$ of the multiple choice questions correct to still receive a 5 on the AP English Language and Composition exam, as long as they write strong essay responses. This reminder continued throughout class as William moved around the room and asked students if they were continuing to hit the $50 \%$ mark. 
After the initial reminder about only needing to get $50 \%$ correct, William reviewed strategies that would be helpful in approaching the multiple choice questions. These strategies included figuring out if a question was focused on close reading or textual analysis and suggestions for figuring out unknown vocabulary words. The students were then instructed to answer the multiple choice questions in groups by talking through each question, eliminating options, and explaining why they were incorrect. While the students were working in groups, I observed them notice the word choices used in the questions and answers. They were also talking through the possible answers and explaining why they thought certain answers could be immediately eliminated. Students also spent a great deal of time discussing and defining terms that were unfamiliar. Throughout this class session William moved around the room and continued to ask individual students "Why did you miss the ones you missed?” (Observation 19 March 2014). Many students came to the conclusion that it is time consuming to read the passage(s) thoroughly and then spend time answering each question.

Although this type of instruction and practice is very useful in preparing students to take the AP English Language and Composition exam, and arguably other types of standardized assessments, it is not well-matched to the focus and instruction in first-year writing courses. It appears that the instruction at Blue Meadows High School that focuses on preparing students to answer the multiple choice questions on the AP English Language and Composition exam centers not so much on the content or knowledge needed to provide a successful answer but on strategies for test taking. While this is problematic in terms of its compatibility to first-year writing courses, students are being taught to actively reflect on their choices, which does align with the Framework for 
Success in Postsecondary Writing ${ }^{59}$, specifically the habit of mind focusing on metacognition.

Not only were students working with practice multiple choice questions for the AP English Language and Composition exam, they were also examining student responses released by the College Board for the 2010 AP English Language and Composition Free-Response Question 2 (Form A) during this class session. This particular prompt presents a passage from a letter written in 1791 from Benjamin Banneker to Thomas Jefferson and George Washington. The students are instructed to "Read the following excerpt from the letter and write an essay that analyzes how Banneker uses rhetorical strategies to argue against slavery" (Prompt). William explained that before he assigned the prompt he spent time discussing the importance of focusing on "syntax, diction and tone on the analysis prompt because it is always there" to be analyzed, unlike other rhetorical elements (Observation 19 March 2014). They had written a response to this prompt for homework. At the start of class, William instructed the students to highlight their thesis statement and mark one paragraph. The students were then instructed to use the exemplars from the College Board to score their response. He collected responses at the end of class. He later explained to me that he would look at their thesis statement and if the thesis statement presented a sound argument, move on to reading the paragraph that the student had marked. Therefore, students were only receiving feedback on how well their thesis answered the prompt and, possibly additional feedback on a single supporting paragraph.

\footnotetext{
${ }^{59}$ For a fuller discussion on the ways in which the AP English Language and Composition outcomes intersect with the Framework for Success in Postsecondary Writing see chapters three and four.
} 
This writing experience is representative of the formal writing that students in AP English Language and Composition at Blue Meadows High School complete, based on my observations. The focus is very much on writing successful exam responses and on strategies, such as focusing on specific elements guaranteed to appear on the exam, and structuring the response in such a way that features, such as the thesis statement, are clear for the exam scorer. While this type of writing instruction is not necessarily bad, it relies on narrow conceptions of writing that follow a formulaic approach. For example, students are being taught to compose in response to a very narrow rhetorical situation and follow a 3.5 essay format. Moreover, while it is encouraging that the students are examining models of other students' writing, it is troubling that the task is narrowly prescribed so that students are examining the samples in terms of successful writing for the AP English Language and Composition exam and not in terms of successful academic or argumentative writing. In short, the writing instruction that I observed at this particular location is tailored to the expectations for writing held by the AP English Language and Composition exam and not first-year writing courses.

\section{Student Perceptions}

According to survey and interview data ${ }^{60}$, the majority of students enrolled in AP English Language and Composition at Blue Meadows High School view AP English Language and Composition as an alternative to taking first-year writing at postsecondary institutions. The data shows that $23.5 \%$ of students disagreed and $17.6 \%$ of students strongly disagreed when asked: "I plan on enrolling in some type of first-year writing class during my first year of college" (survey). Moreover, this attitude was echoed during

\footnotetext{
${ }^{60}$ See chapter two for a description of survey and interview methods.
} 
interviews with students. Leslie explains, "I just really wanted to get college credit. Basically, so I wouldn't have to spend so much time in school” (Interview 27 May 2014). Dylan has a similar response when he tells me that he enrolled in this class "to get college credit for it so I can get out of taking the course in college" (Interview 27 May 2014). Likewise, Eric explains that he wanted to take this course "to get exempt from introductory college classes" (Interview 27 May 2014). On a similar note, Joyce tells me that she is enrolled "pretty much for the college credit and hopes to be able to get out of it in college" (Interview 27 May 2014). While Leslie, Dylan, Eric and Joyce are wanting to "get out of taking" first-year writing, Jeffery and Charles have the same goal but point to the financial implications that not having to take an additional course in college will have on their future. Jeffery explains that he is enrolled "to get the credit out of the way so I don't have to pay for it later on" (Interview 27 May 2014). Similarly, Charles directly tells me that he "just wanted to save money in college because it's cheaper [to take AP] than taking the actual [first-year writing] course" (Interview 27 May 2014). In short, students enrolled in AP English Language and Composition at Blue Meadows High School view this course as a replacement for first-year writing and not as a means to place into an appropriate first-year writing experience as Jolliffe and Phelan suggest in their argument about the relationship between AP English and first-year writing placement ${ }^{61}$.

Given the data collected for this project and the findings discussed in the previous section, it is troubling that the majority of students enrolled in AP English Language and

\footnotetext{
${ }^{61}$ Jolliffe, David A., and Bernard Phelan. "Advanced Placement, Not Advanced Exemption: Challenges for High Schools, Colleges, and Universities." Delivering College Composition: The Fifth Canon. Ed. Kathleen Blake Yancey. Portsmouth: Boynton/Cook, 2006. 89-103. Print.
} 
Composition at Blue Meadows High School feel that the course is preparing them for college level writing tasks when, in reality, it is operating to prepare them to construct essay responses for the AP English Language and Composition exam and gain credit that will possibly allow them to bypass first-year writing requirements. Even though $20.6 \%$ of students strongly agreed and $47.1 \%$ of students agreed that their "AP English Language and Composition course is preparing me for college level writing tasks" (survey), students expressed a contradicting attitude toward this subject during interviews, with many students expressing that they felt the class was tailored to helping them pass the AP English Language and Composition exam. For example, while some students felt the course was to prepare students for the writing they would be asked to complete in college, many felt the purpose was to pass the AP English Language and Composition exam. When asked about what she saw as the purpose of the course, Leslie responded that the "focus [is] on passing the test, not necessarily on obtaining the knowledge" (Interview 27 May 2014). Damion agreed with Leslie. He explained that he felt that "at [Blue Meadows High School], I think it [the purpose] is just to get college credit" (Interview 27 May 2014). On a similar note, Ruth explained that the purpose of the course is "strictly for passing the AP exam, to get...that college credit, mostly" (Interview 27 May 2014). The survey and interview data, taken together, lead me to conclude that it is possible that students at Blue Meadows High School realize that their experience in AP English Language and Composition does not align with the practices of many first-year writing courses. However, some of the interview responses indicate that students are aware that the purpose that the course serves should be greater than allowing students to obtain a passing score on the AP English Language and Composition exam. 
Jill comments that "I think it prepares you to pass the test but I don't know if it actually prepares you for college" (Interview 27 May 2014). Similarly, Damion tells me that "I don't know how much it will help me when I get to college except for the fact that it has already given me college credit” (Interview 27 May 2014). In short, even though the course is supposed to be the equivalent of first-year writing, the majority of writing that students complete for this course focuses on composing responses to released prompts to the AP English Language and Composition exam or short in-class writings in response to given prompts. These practices do not align with the practices of many first-year composition courses at many universities and student appear to recognize this discrepancy.

\section{Conclusions}

Although this AP English Language and Composition course at Blue Meadows High School does align with the College Board's outcomes for the course, it does not resemble a first-year writing course because the writing and writing instruction is centered on composing AP English Language and Composition exam essays. However, AP English Language and Composition at Blue Meadows High School does reflect the pressures that implicitly influence the course, such as the high-stakes assessment and financial incentives that students and their families gain through high achievement on the exam. As discussed in this chapter, students view this course as a way of obtaining precollege credit for writing and avoiding first-year writing when they matriculate to their chosen postsecondary institution. An expectation exists at this location that students will leave this course and perform well enough on the AP English Language and Composition exam to obtain precollege credit for writing. Therefore, pressure exists to increase student 
performance on the exam and this pressure seems to appear in the course through an emphasis on test preparation. Yet, this pressure is not unique to Blue Meadows High School and exists in many high schools across the country. The AP program is growing as more and more students enroll with the belief that the course can lead to the opportunity for precollege credit for writing. This increased enrollment increases the pressure on teachers to provide instruction throughout the course that leads to high performance on the AP English Language and Composition exam. This type of pressure can shift the emphasis away from writing instruction and towards test preparation. At locations where test preparation is the focus, such as Blue Meadows High School, students are most likely participating in a rigorous and challenging course that prepares students well for the exam, but preparing students for the exam does not necessarily equate with providing a course that is similar to first-year writing. This suggests that teachers of writing at both secondary and postsecondary levels need to consider the diversity of practices present within AP English Language and Composition courses and awareness needs to be raised concerning how different AP English Language and Composition can look in different locations 


\section{CHAPTER 7: INNOVATIVE CONSTRUCTIONS OF AP ENGLISH LANGUAGE AND COMPOSITION: PRECOLLEGE CREDIT FOR WRITING AND PREPARATION FOR COLLEGE READINESS}

This chapter presents yet another version of AP English Language and Composition that is guided by framing documents produced by the College Board. While the case study of Violet Fields High School in chapter five presents an exceptional construction of AP English Language and Composition that replicates the first-year writing experience but can only be enacted with the resources and population at this location and chapter six presents the story of an AP English Language and Composition course that focuses on test preparation and literature at Blue Meadows High School that presents a challenging and rigorous course but neglects to provide writing instruction consistent with the practices of first-year writing courses, this case study tells the story of AP English Language and Composition at Red River High School and explores the ways in which the course is being used in innovative ways to serve students not traditionally served by the AP program. As in the previous two case studies, even though the enactment of AP English Language and Composition is bounded by the course outcomes and, ultimately, the exam, the particular circumstances associated with the location heavily influence the shape that the course takes. This chapter investigates innovative uses of the AP program at a school recovering from low performance in order to continue 
to showcase the range of experiences that students encounter in AP English Language and Composition.

Advance Kentucky's mission is to work with local, state and national partners to dramatically expand access to and participation and success in rigorous college-level work in high school, particularly among student populations traditionally underrepresented in these courses.

$\underline{w w w . a d v a n c e k e n t u c k y . c o m}$

\section{College Readiness and Kentucky}

As Kentucky’s Governor Steve Beshear points out, "Senate Bill 1 passed by the Kentucky General Assembly in 2009 brought a new focus on what students actually learn, and aligned that learning to what colleges and employers expect high school graduates to know in order to be successful"' (Speech 28 February 2012). A particularly important change is that, and Governor Beshear is drawing attention to this, college readiness is tightly linked to experiencing success after high school. As Governor Beshear continues to explain, "the definition of a successful student is no longer limited to receiving a high school diploma. A successful student is one who has the knowledge, skills, and abilities to be ready for whatever comes next, whether that is a job that can provide a living wage or some form of postsecondary education" (Speech 28 February 2012). As Governor Beshear indicates, success in terms of completion of secondary education has become obsolete because students must be prepared to succeed once they exit secondary schools. The Common Core State Standards, or Unbridled Learning ${ }^{62}$ as it was renamed in Kentucky, was a watershed moment for redefining the trajectory of

\footnotetext{
${ }^{62}$ This renaming and branding by the Kentucky Department of Education sought to align the educational reform with the state's focus on horse breeding and racing.
} 
education and creating a P-16 pathway of completion. As I address in chapters three and four, the focus on college readiness as a marker of student achievement has gained increased attention since the adoption of the Common Core State Standards in 2009. In order to address the problems that hindered success for students entering postsecondary education, a major focus in Kentucky has been on implementing programs and making curricular changes that increase college readiness and decrease the need for remediation once students enter their chosen postsecondary institution.

Moreover, the Southern Regional Education Board (SREB) refers to the need for remediation as the "readiness gap" and argues that "[t]he college readiness gap reflects the disparity between the skills and knowledge that students gain in high school versus the skills and knowledge that colleges and universities expect" (3). Students that enter postsecondary institutions in need of remediation are less likely to graduate. In fact, the SREB asserts that "[1]ack of readiness for college is a major culprit in low graduation rates, as the majority of students who begin in remedial courses never complete their college degrees" $(2)^{63}$. While many students and parents are under the false impression that a college preparatory curriculum will prepare students for success in college, research has shown that many students completing a college preparatory program in secondary school are still in need of remediation when they enter their chosen postsecondary institution. Among the numerous critiques of college preparatory curriculum, three important criticisms are addressed in "Beyond Rhetoric: Improving College Readiness Through Coherent State Policy" published by SREB. These critiques include: "P-12 and postsecondary expectations are disconnected"; "Courses and seat time

\footnotetext{
${ }^{63}$ This topic is also addressed in the Remediation: Higher Education's Bridge to Nowhere published by Complete College America.
} 
do not guarantee skills and knowledge;" and "Traditional readiness assessments do not measure college readiness" (4-5). These three criticisms are important to consider for this project because they are reduced, and arguably eliminated, through encouraging students to enroll in AP courses as a way to increase college readiness. For example, the College Board positions the AP English Language and Composition course to mimic expectations of outcomes and skills required of first-year college composition course by borrowing heavily from the WPA OS. AP English Language and Composition teachers also participate in a syllabus audit "to provide secondary and higher education constituents with the assurance that an 'AP' designation on a student's transcript is credible, meaning the AP Program has authorized a course that has met or exceeded the curricular requirements and classroom resources that demonstrate the academic rigor of a comparable college course" (Course Description 1). Furthermore, even though the SREB points out that "courses and seat time do not guarantee skills and knowledge," student performance on the AP English Language and Composition exam is a measurement of skills and knowledge of the skills covered in the outcomes. And, although "traditional readiness assessments do not measure college readiness," there is significant research supporting the benefits of AP coursework and links between AP enrollment in secondary school and success in postsecondary education. In short, while seat time does not correlate to knowledge gained and retained in any course, not just AP, AP offers an end of course assessment that the College Board claims is an effective indicator of the skills covered in the course.

Since their creation in 1954 by the College Board as a way for advanced students to begin work on college-level material while still enrolled in high school, AP courses 
have continued to increase in popularity. Even though the AP program was originally conceived as an instructional and assessment program for a small minority of exceptionally gifted students, currently students of all academic levels are permitted to enroll in AP courses because of the combination of rising college costs and the association of the AP program with rigor, challenge, and academic excellence in the larger culture. Whereas the intention of the College Board is to provide students with college credit before they enroll in postsecondary institutions, AP is also being used in innovative ways as a site to help increase college readiness through programs, such as Advance Kentucky. Because course rigor is an essential element of promoting college readiness and preparing students for the experiences that they may face after they exit secondary schools, innovative programs, such as Advance Kentucky, are providing opportunities to expand a program—AP—already known for its rigorous and challenging curriculum to students not traditionally served. While much scholarship focuses on the benefits that the challenging curriculum and rigorous pace of AP courses provide students, this prior work has focused on traditional configurations of AP courses where the students selected for the courses are ready for advanced course offerings that offer the possibility of college credit. This scholarship is discussed in some detail in chapter one. However, studies that focus on pedagogically innovative uses of AP curriculum to serve populations of students not typically served by the AP program in preparation for college need to be developed and the effectiveness of these programs investigated.

In this case study, I examine how Red River High School's participation with Advance Kentucky facilitates an open enrollment policy for AP courses and address the influence that this relationship has on AP English Language and Composition and writing 
instruction. Specifically, I start by examining the institutional effects that Advance Kentucky had on Red River High School and the way in which the English department functioned. I then move to investigating the daily instructional practices of AP English Language and Composition and student perceptions of the course and of college writing. In short, using data collected between February 2014 and June 2014 from classroom observations, institutional documents - minutes from planning meetings, ACT test scores, AP test results—interviews with the AP English Language and Composition teacher, course documents — scope and sequence, formal assignment prompts, daily work prompts—and student interviews, this chapter investigates how the Advance Kentucky model is enacted at a particular location at the administrative and classroom level. It also examines the positive changes that resulted from this partnership and the ways in which the pedagogical innovations adopted to align with the mission of Advance Kentucky led to increases in student achievement in both English and Reading on standardized assessment measures. Additionally, it looks at how college preparation in reading and writing were emphasized through the curriculum for AP English Language and Composition. This chapter concludes by discussing possible implications for writing instruction and college readiness.

I'm interested in how it goes because this is our first year doing it...Because Advanced Kentucky is predicated on you don't gate keep, that idea of a kid doesn't have [a certain qualification], they don't get in the program goes away. So, I'm going to be interested to see how it works. Now, am I going to have a $74 \%$ pass rate this year? Certainly not, but it's kind of changing your mindset to it's not about the pass rate. It's about the amount of kids that pass. It is a completely kind of different shift because I 
think a lot of AP teachers get too wrapped up in their pass rate because they seem to think that is reflection on them. I guess to an extent it is. But this is not about you, it's about the students. You got your education, hopefully. So, your job [should probably be] preparing these kids for college. Well, wouldn't it be more advantageous that more kids have access to this curriculum?

\section{Owen (Interview 20 March 2014)}

\section{Becoming Part of Advance Kentucky}

In the above statement, Owen addresses the ways in which being an Advance Kentucky school changed the mindset concerning AP courses at his school and stresses the importance and benefits of opening access to the AP English Language and Composition curriculum to a wider variety of students in order to better prepare them for postsecondary education. He also comments on important elements—open enrollment, exam pass rate, and college preparation — that will be further investigated in this chapter. It is important to note that Owen is reacting to the changes Red River High School and he, as the AP English Language and Composition teacher, had to make as the school expanded their AP program. These institutional changes influence how AP courses are structured and how teachers work together to increase college readiness for students within these courses. Specifically, in AP English Language and Composition, the conception of writing instruction as a means of college preparation is expanded to a larger portion of the student population, and this expansion results in instructional modifications.

Red River High School practices open enrollment for AP courses because of its participation in Advance Kentucky. This means that any student who wishes to enroll in 
an AP course is allowed. The school counselors and teachers encourage students who would not traditionally be encouraged to enroll in AP courses to enroll based on their work ethic and determination. Because of participation in Advance Kentucky, Red River High School is provided with extra resources to support the increased enrollment and nontraditional AP students. In addition to extra resources provided by Advance Kentucky, Red River High School is required to engage in vertical planning so as to better prepare students to enter the rigors of AP coursework.

\section{Supplemental Instruction at Red River High School}

It is encouraging that measures are taken through supplemental programs to provide extra assistance through optional afterschool writing instruction. This extra assistance comes in two forms: afterschool sessions and Saturday sessions. In afterschool sessions, Owen extends the instruction that has been provided during class. These sessions allow students extra time to ask questions, practice reading strategies, engage in additional analysis, and receive small group and individualized assistance and writing instruction. In order to assist students in making good use of their time, Owen advertises what each session will cover so students can decide how to spend their afterschool time.

While Owen plans the afterschool sessions, the Saturday sessions are more structured, as is required by Advance Kentucky. In the Saturday sessions, Advance Kentucky plans an enrichment program for schools in the same region, and speakers are brought in to present on different aspects of the AP English Language and Composition exam. The Student Study Session Framework provides an overview of what should occur. During the first Student Study Session, individual AP English teachers are responsible for conducting the session at their own school and covering content that their students need 
emphasizing. During the second Student Study Session, students take a mock-exam that will be scored by teachers participating in Advance Kentucky. During the third Student Study Session, AP English Language and Composition teachers deconstruct the mockexam. These Student Study Sessions allow students to become more familiar with the exam, content that is covered on the exam, gain practice taking the exam, and revisit their strengths and weaknesses as they review the mock-exam under the expert guidance of an AP English Language and Composition teacher. This type of support is crucial for students new to the AP program or performing academically below where tradition AP students perform. However, Owen was not overly impressed with these sessions and felt that he could have provided his students with stronger instruction. (Interview 18 December 2014). Although the availability of extra opportunities is beneficial for students, it is potentially troubling that these resources are afterschool and optional because some students cannot or will not take advantage of these opportunities, even though they could benefit from the additional writing instruction and individualized attention that these sessions provide.

\section{Preparing Students for the Rigors of AP}

In addition to supplemental instruction, one of the key elements of placing students capable of successfully completing AP English Language and Composition is the preparation that these students receive during their freshmen and sophomore years at Red River High School. Through the implementation of vertical team meetings, Red River High School seeks to prepare students for the rigors that accompany AP coursework. While these meetings began with a basic overview of Advance Kentucky, teacher resources, and AP English exams for involved teachers, later meetings focused on 
and continue to focus on ways in which all teachers could better structure their classes so to better prepare students to enter AP courses. An unspoken outcome of the initial meeting was an increased awareness about what other teachers were doing in their classrooms. Moreover, vertical teams allow for important considerations to be addressed and discussed to better serve and prepare students to move from one grade level to the next. For example, at the January 2014 meeting two important issues were brought up to all of the English teachers teaching students who might later filter into AP English courses. These issues include: course requirements and workloads for students in pre-AP courses and criteria to move students in and/or out of AP English courses. Both of these issues hold important implications. With the influx of students due to the new open enrollment policy, the AP English teachers, both for Language and Literature, wanted to address issues they saw arising in their courses based on students' level of preparation, or lack thereof. Therefore, the AP English teachers framed the issue around the following point: "many of the negative issues arising from this year's move to an increased AP enrollment is [sic] the lack of student preparation for AP coursework" (January 2014 Meeting Minutes). However, instead of lamenting this problem, the vertical team meeting allowed the AP English teachers to open a dialogue with the ninth and tenth grade teachers and develop a plan of action to better prepare students to enter AP English courses. In short, vertical team meetings, while required of schools participating in Advance Kentucky, function to align student experiences across grade levels and prepare students to enroll and successfully complete AP English courses. 


\section{Marketing to Nontraditional AP Students}

Because AP has long been associated with the academically gifted, schools practicing open enrollment for AP courses must actively recruit students. In encouraging students to enroll in AP courses, Advance Kentucky distributes promotional materials to students and parents. Interestingly, four out of the nine benefits for students that Advance Kentucky stresses focus on financial considerations. Advance Kentucky tells students that "AP students: who are in Advance Kentucky schools receive \$100 per qualifying score of 3,4 , or $5 \ldots$ have a better chance to earn $\operatorname{KEES}^{64}$ money...Are more likely to keep their KEES awards in college...Reduce college expense" (Why Take AP?). Thus, cost and the potential for future savings is a marketing technique designed to entice increased student enrollment. The increase in enrollment in AP English Language and Composition at Red River High School is a possible result of this type of marketing, as students are aware of potential financial incentives tied to strong performance on AP exams and cited this during interviews as a reason for wanting to enroll in AP coursework. Furthermore, the promotional material stresses the increased long-term earning potential for individuals that graduate college. Through the use of present and future financial incentives and possibilities, Advance Kentucky seeks to link AP coursework, college preparation, and positive financial outcomes. Emphasizing the financial benefits of AP, college preparation, and postsecondary education is an effective strategy for Red River High School because of the population of students that it serves.

\footnotetext{
${ }^{64}$ KEES stands for Kentucky Educational Excellence Scholarship. According to the Kentucky Higher Education Assistance Authority, "The KEES program provides scholarships to students who earn at least a 2.5 GPA each year they attend a certified Kentucky high school. The better they do in high school, the more they earn toward college. They may also earn awards for ACT/SAT scores and Advanced Placement (AP) or International Baccalaureate (IB) test scores" (https://www.kheaa.com/website/kheaa/kees?main=1). Accessed on 11/9/2014.
} 
While opening enrollment to all interested students is a positive move, the imagined student for this course still comes from the advanced track of students. As Owen explains, "[t] here is no cut off. Part of [preparing students is a very, very good sophomore advanced English teacher. And if that person follows a good sophomore advanced curriculum and has the rigor then" the students from that class are probably ready to enroll in AP English Language and Composition (Interview 29 October 2014). Therefore, even though nontraditional AP students are actively recruited, AP courses, such as this one, are still out of reach for certain populations of students because the recruitment is directed at students already placed in the advance track.

\section{Student Diversity within AP English Language and Composition}

Because of Red River High School's participation in Advance Kentucky and active recruitment, a variety of students enrolled in three sections of AP English Language and Composition during the 2013-2014 school year. The diversity spanned gender, socio-economic status, race, language, and academic ability. The students also come from diverse backgrounds in terms of prior AP experience with some students having taken all of the AP courses they were eligible for at Red River High School, others taking one AP course a year, and still others trying AP courses for the first time with AP English Language and Composition. It is because of this diversity that AP English Language and Composition takes its shape at Red River High School.

This diversity is also reflected in the college readiness benchmarks of students enrolled. For example, the ACT Plan English scores for students entering AP English Language and Composition in 2013 were between 13 and 27. Moreover, at this time, there were thirty-eight students not meeting the college readiness benchmark of 18 . 
During this same period, ACT Plan Reading scores were between 13 and 28, with fortyseven students not meeting the college readiness benchmark of 20 . This means that many of these students, without substantial gains in most cases, would place into developmental writing and reading courses at the postsecondary level and would most likely not be admitted to the larger four-year public institutions in the state ${ }^{65}$. Remarkably, scores in both of these categories saw a substantial increase in March when students took the official ACT exam, and after having engaged in the AP English Language and Composition curriculum for almost eight months. At this time the English scores were between 14 and 32, with only six students not meeting college readiness benchmarks. The Reading scores were between 14 and 32, with only seventeen students not meeting the college readiness benchmark of 20. The average English score increased to 22.54. This is an increase of 4.45 points. The average Reading score increased to 22.47 . This is an increase of 3.79 points. Comparatively, students not traditionally enrolled in $\mathrm{AP}^{66}$ saw an average growth of 4.1 in English and 5.5 in Reading. Students not enrolled in AP English Language and Composition saw an average English gain of 2.3 points and a Reading gain of 2.25 points.

Accordingly, not only did non-AP English Language and Composition students at Red River High School see a larger than average increase than the state as a whole, students enrolled in AP English Language and Composition achieved scores that were higher than the state average in both categories, with several students making impressive individual gains. Despite the positive outcomes that result from having a range of

\footnotetext{
${ }^{65}$ For example, the University of Louisville and the University of Kentucky recommend an ACT composite score of 22 or higher.

${ }^{66}$ I am classifying students not traditionally enrolled in AP as students scoring 15 or below in English and/or Reading on the PLAN or ACT. Although it is important to note that standardized assessment measures are not the only criteria used to indicate a student traditionally served by the AP program.
} 
students in the class, it is troubling that certain types of students - those already in the advance track - are actively sought out and offered the AP experience when there are many other potential students that are not being encouraged as strongly. This is especially disheartening when considering the gains towards college readiness that nontraditional AP students experienced after enrolling in AP English Language and Composition.

\section{Measuring for College Readiness}

It is important to note, at this point, that measuring for college readiness is complicated, and standardization between locations is extremely important. Because of this, many states, Kentucky included, have decided to use benchmark scores on the ACT to measure for college readiness. The ACT college readiness benchmark for English is 18. The ACT college readiness benchmark for Reading is 20. "The Reality of College Readiness," a report issued about the state of Kentucky by ACT, explains that the "benchmarks are ACT subject area scores that represent the level of achievement required for students to have a $50 \%$ chance of obtaining a B or higher or about a $75 \%$ chance of earning a $\mathrm{C}$ or higher in a corresponding credit-bearing first-year college course" (3). While correlations between benchmark scores and anticipated performance are one way to look at the importance of benchmark scores, benchmark scores also allow performance to be compared from multiple locations within the state, region, and nation. For example, in August 2014 the Kentucky Department of Education released data that showed that "[f]rom 2010-2014, Kentucky public school students registered from a halfpoint to more than a full-point gain in every subject and nearly a one-point improvement in the overall composite score-up to a 19.9 on a 36-point scale. At the same time, student performance nationally stayed nearly unchanged" (1). While benchmark scores 
are one indicator of college readiness, it is also important to look at the learning outcomes that are associated with meeting benchmarks. For example, the Kentucky Department of Education released outcomes for each subject area where students are expected to achieve college readiness. These outcomes indicate the skills that students should demonstrate competency in at the end of a developmental course ${ }^{67}$. For writing, there are eight outcomes that overlap with the WPA $O S$ and the experiences identified in the Framework for Success in Postsecondary Writing. While this project focuses on writing instruction within classroom practices, one way of examining the effectiveness of these classroom practices is to compare results indicating college readiness before and after enrollment in AP English Language and Composition. In short, growth in ACT English and Reading scores provide evidence of student progress that may be attributed to classroom practices and allows a comparison across the district and state. In addition to the gains that students are showing on the ACT in Kentucky, the Kentucky Department of Education also notes that "there is a strong correlation between student performance on the ACT and the rigor of the courses a student takes in high school" (3). Course rigor is also an important factor in assisting students in becoming college ready and developing dispositions that lead to success in postsecondary writing ${ }^{68}$. The College Board's AP program has a long and documented history of preparing students to be successful at the postsecondary level ${ }^{69}$.

\footnotetext{
${ }^{67}$ See the appendix for this document.

${ }^{68}$ For a larger discussion of the Framework and AP English Language and Composition, see chapters three and four.

${ }^{69}$ For more information about the connection between AP coursework and postsecondary success see: McKillip, Mary E. M., and Anita Rawls. "A Closer Examination Of The Academic Benefits Of AP." Journal Of Educational Research 106.4 (2013): 305-318. Academic Search Complete. Web. 10 Nov. 2014 ; Pahl, Larry. "Another Look At AP." Social Education 78.1 (2014): 38-44. Academic Search Complete. Web. 10 Nov. 2014; Scott, Tim, Homer Tolson, and Yi-Hsuan Lee. "Assessment Of Advanced Placement Participation And University Academic Success In The First Semester: Controlling For Selected High School Academic Abilities." Journal Of College Admission 208 (2010): 26-30. Education Full Text (H.W. Wilson). Web. 10 Nov. 2014.
} 


\section{Mixing Traditional and Nontraditional AP Students}

It could be potentially problematic that students of all academic levels are mixed together in AP English Language and Composition at Red River High School because concerns over watering down the curriculum arise. The dynamics change when nontraditional students are mixed with traditional AP students. The range of academic levels in the class presents the possibility that changes could be made to the curriculum in order to accommodate the nontraditional students and, therefore, potentially lead to an altered experience for the traditional AP students. However, the decision to mix traditional and nontraditional AP students in English Language and Composition at Red River High School was made after deliberate consideration of the alternatives. As Owen explains,

Oh it's random. You've got every kind of kid in each class. They are in there together. It's not like I've got: smart class, medium class, traditionally not an AP kid class... We batted that idea around and we even batted that idea around that even if that was possible for scheduling, would we want to do that? And I've batted that around of whether we would or not because part of me says yes — separate them based on their PLAN score and their GPA. Because I would teach that section differently than I would teach this other section. But then my concern with that would be how much... would I devolve my teaching to meet their concerns as opposed to...leave my teaching the same and let them rise to that. Then, I come to the conclusion if they are all dumped in with these kids 
[traditional AP], they're not rising to meet me, they are rising to meet their peers. (Interview 29 October 2014)

Moreover, the nontraditional AP students recognize that there is something different about traditional students. As one student tried to explain, she found that "AP kids had a different way of thinking about things" (Interview 23 May 2014). Although nontraditional AP students noticed a difference being in class with traditional AP students, the traditional AP students were not as clear on if they benefited from being in class with nontraditional AP students, aside from the fact that they found the focus on reading comprehension strategies helpful. Therefore, while the class dynamic is definitely altered, the traditional students did not indicate that these changes result in a negative experience.

As discussed in this section, the administration and the AP English Language and Composition course at Red River High School underwent change in order to align with the goals and mission of Advance Kentucky. These changes include expanding open enrollment through the recruitment of students not traditionally included in AP courses, the use of extra resources to provide supplemental instruction to students, and the formation of vertical teams to ensure that students moving from grade level to grade level are better prepared to enroll in AP English Language and Composition. Now that the institutional changes have been addressed, I turn to examining the instructional practices incorporated in AP English Language and Composition and the ways in which these practices work to prepare students for postsecondary writing experiences.

This class is kind of half and half. I think the big misconception about this class is that it is all writing. And I think that's kind of the big misunderstanding. It's not all writing. 
It is largely trying to teach these kids to understand how rhetoric works. So, it is probably half and half. Half the reading, critiquing, and analyzing other people's writing and then it is your own writing. So, it is a twofold purpose. That's why the exam is set up-you analyze this person for effect and purpose and then you write for effect and purpose.

Owen (Interview 9 April 2014)

\section{Reading and Writing in AP English Language and Composition}

This quote, by Owen, illustrates the scope of AP English Language and Composition as it plays out at Red River High School. It also is an attempt to clarify for those outside secondary English classrooms the focus of the course. Owen explicitly references what he sees as the misinterpretation of AP English Language and Composition, namely that the course is all writing. It is understandable that those outside the course may view it solely in terms of writing because the course is most often viewed as a precollege credit for writing option and a way for students to gain credit for first-year composition - a course focused on writing. While both reading and writing instruction are included in AP English Language and Composition and the course works to prepare students for the types of reading and writing experiences they will experience in postsecondary education, the investigation below finds that the course is a very effective reading course. However, some tensions and contradictions arise between the writing instruction included in this course and practices of first-year college writing courses.

The dual focus on reading and writing is also illustrated by students when asked to talk about what they had learned in AP English Language and Composition. Amy explains, she feels this class taught her "how to scan through texts and find...what's 
really important in them" (Interview 23 May 2014). She also "feels[s] like... [she] is making better arguments that are stronger and a little more backed up with evidence" (Interview 23 May 2014). Matthew concludes that he learned "mainly just how to write better...how to make an argument clearer... [and] how to pick up on little things when you're reading" (Interview 23 May 2014). Likewise, Patrick feels this class taught him "how to argue a lot better...how to compose an essay... read in-depth...gaining sources or evidence from the passage" (Interview 23 May 2014). James also discusses how AP English Language and Composition helped him grow as a reader and writer. He explains that he learned "academic writing — making strong arguments through rhetoric" (Interview 23 May 2014). His reading skills have also grown as the course helped train him to employ “active reading” skills (Interview 23 May 2014). The students' experiences are reinforcing Owen's point that the exam is clearly assessing both reading and writing skills.

\section{Reading}

As is the case in many classrooms across America, the range of student ability widely varied in AP English Language and Composition at Red River High School, and this variation influenced the way in which the course was structured. Owen spends the first trimester focusing on reading skills because as he explains,

The first probably 6 weeks of the class is just focusing on reading. I'm trying to teach these kids to read for the uses of rhetoric. Instead of just reading for plot summary, or reading for theme or conflict... I'm trying to shift their focus on how to read nonfiction. That you can't read nonfiction the same way you do fiction. It's a different mindset because if I don't 
teach them that you have to read that differently, how am I going to teach them that you write about it differently" (Interview 29 October 2014)?

As the discussion of ACT English and Reading scores indicate, the students spread across a wide range in terms of meeting college readiness benchmarks and because of this, individual ability to complete the tasks asked of students on the AP English Language and Composition exam varies greatly. Therefore, Owen starts with reading comprehension and text analysis strategies because this allows students already possessing these skills additional practice and provides students needing to develop these skills a chance to acquire and practice them. For example, after reading and discussing Francine Prose's "I Know Why the Caged Bird Cannot Read," the students complete ten questions that ask them to explore the rhetoric that Prose employs and consider the stylistic elements of the text. These questions ask students to analyze for ethos and logos, consider diction and audience, and identify the claims and assumptions that Prose makes throughout her argument. Students also focus on reading skills again when they read James Baldwin's “A Talk to Teachers". At this time, students continue to exercise close reading skills as they consider diction and audience, analyze for ethos and pathos, and examine stylistic effectiveness. Once again, students continue practicing critical reading when reading Henry David Thoreau's “Where I Lived, and What I Lived For”. Again, students are asked to explore the rhetoric that Thoreau employs and consider his stylistic choices. Specifically, at this point, students are asked to consider the ways in which the use of specific rhetorical devices — antitheses, simile, metaphor, repetition, parallel structure, rhetorical questions, paradox, allusion, alliteration-produce certain effects throughout the text. This focus on analyzing texts for rhetorical and stylistic elements 
continues as students read the following: Virginia Woolf's “Thoughts on Peace in an Air Raid" and "Professions for Women," George Orwell's “Shooting an Elephant," Chris Hedges' "The Destruction of Culture," Paul Theroux's "Being a Man," and Deborah Tannen's “There is No Unmarked Woman". These texts are all read during the first trimester, along with other supplemental handouts and questions provided by Owen. As the above paragraph shows, students in AP English Language and Composition at Red River High School engage with strategies for reading. This time spent on reading instruction, while not explicitly part of the outcomes for the course, helps prepare nontraditional AP students for postsecondary education experiences by allowing them time and space to practice skills linked to college readiness and measured on standardized assessments that measure college readiness. It is also helps students traditionally served by the AP program because these students also see increases in college readiness indicators. For example, students at Red River High School not enrolled in AP English Language and Composition saw an average gain of 2.25 in Reading between the ACT PLAN taken during sophomore year and the ACT taken in March of their junior year. However, students enrolled in AP English Language and Composition saw an average gain of 2.75 points in this same time period. While the gain experienced by AP English Language and Composition students in 2013-2014 is not as large as the gain experienced by students enrolled in the 2012-2013 school year ${ }^{70}$, the course in 2013-2014 enrolled more students and many of these students were entering at a lower level. So, while the gains are not as great, they are still impressive, especially considering the individual gains that some students experienced.

\footnotetext{
${ }^{70}$ AP English Language and Composition students in the 2012-2013 school year had the following gains: English 4.66; Reading 4.86.
} 
Individual students enrolled in AP English Language and Composition saw gains as high as 12 points in Reading, when the national average gain is around 2 points. These gains are important because they mean that students, even students missing college readiness benchmarks by five or more points at the start of their sophomore year, are meeting those benchmarks and achieving college readiness, or at least coming closer to achieving college readiness ${ }^{71}$. Yet, these types of gains are not unusual for students enrolled in AP English Language and Composition, as they existed before Red River High School began expanding enrollment through participation in Advance Kentucky. For many of the nontraditional students, the average gains achieved by non-AP English Language and Composition students would not have been enough to render them college ready. It is remarkable that so many students were able to make such large gains in Reading, and these results can quite possibly be attributed to the rigorous reading activities that students in AP English Language and Composition complete, as this is a trend that also occurred in the previous year.

Both traditional and nontraditional AP students are becoming stronger readers after enrolling in AP English Language and Composition and evidence of this is reflected on standardized assessments that measure college readiness. While the average ACT growth was only slightly greater than those students not enrolled in AP English Language and Composition, the number of students making large gains allow for a greater impact on individual students. If nontraditional students were not experiencing the rigorous and challenging work associated with AP English Language and Composition, many of them would risk not meeting college readiness benchmarks and enter postsecondary

\footnotetext{
${ }^{71}$ See the appendix for a chart depicting the gains made by students enrolled in AP English Language and Composition during the 2013-2014 school year.
} 
institutions in need of remediation. This growth also lends support to arguments about the benefits students exposed to AP curriculum experience and shows that this curriculum works for a lot of students. While it is important to note the gains experienced by the majority of students enrolled in AP English Language and Composition, it is also important to note that not all students experienced gains. For example, thirteen students had Reading scores that either remained the same or decreased. The lack of progression towards college readiness for these students may indicate that, although ample support was provided at Red River High School, these students needed still additional support.

\section{Writing}

While reading is important, students are experiencing even larger gains in meeting college readiness benchmarks in English, which claims to measure writing. For example, students enrolled in AP English Language and Composition saw an average gain of 2.3 in English, while students enrolled in AP English Language and Composition saw an average gain of 4.37 during this same period. It is even more interesting to note that individual students saw gains as high as 9 points. Additionally, thirty-eight students were not meeting college readiness benchmarks at the ACT PLAN and only six students were not meeting college readiness benchmarks after taking AP English Language and Composition. And, many of these students would not have been able to achieve college readiness status with the average increase students not enrolled in AP English Language and Composition experienced. This can possibly be attributed to the writing instruction that takes place in AP English Language and Composition. In what follows, I highlight some of the writing tasks and instruction that the students engage with throughout AP 
English Language and Composition at Red River High School and discuss the ways in which the writing instruction functions to prepare students for postsecondary experiences.

\section{Close Reading, Rhetorical Analysis, and Synthesis}

The first four formal writing assignments that students in AP English Language and Composition complete extend close readings of texts that began during informal class assignments. These four assignments, which I discuss in more detail below, require students to closely read and analyze a text, or in some instances multiple texts, and communicate the analysis through composing written essays. It is interesting to note that all of these assignments are described in detailed assignment prompts that resemble assignment prompts used in first-year writing courses. Moreover, it is also interesting to note that while the assignment sheets are detailed and directive in relating information about structure and topics to be covered in each paragraph, they become less directive as the course progresses, and the assignments increase in difficulty. Although, the directive nature of the assignment prompts decrease, they do still continue to promote and encourage use of the 3.5 essay structure, with this being the organizational model detailed and tailored to the specific assignment. This repeated emphasis on the 3.5 essay has the potential to lead students to believe that this is the structure used in first-year college writing classes, when it is this very structure that first-year college writing teachers work against. In what follows, I examine the formal writing assignments that require students to perform close readings of text.

For the first assignment, students are asked to continue the close reading of two texts they worked with during class and make an argument that connect the ideas in each. As the assignment sheet explains, "Francine Prose and James Baldwin both assert that the American education system is broken. While they both have very different approaches, 
they each share a disdain for how America's youth is being taught. In a 3-5 page essay, synthesize their ideas into one cogent, central thesis. Then, explain how they use rhetorical strategies to exemplify and support their shared claim" (Paper Assignment \#1 1). Students have support from the classroom instruction provided by Owen during the reading and discussion of each of these texts. Yet, this first assignment asks students to branch out from the close reading that they will be required to do for all texts in this course and begin to focus on ways of analyzing texts rhetorically through writing.

Interestingly, the assignment sheet for this paper is very directive ${ }^{72}$, as are all of the assignment sheets for formal writing for Owen's AP English Language and Composition course. For example, students are informed that "[t]he first paragraph should give a brief overview of each author's main arguments. Then provide a thesis sentence that states a synthesized, central thesis that both Prose and Baldwin would agree on" (1). Basically, the assignment sheet is telling students how they should introduce their synthesized argument. This direction goes even further when the assignment sheet provides a template for the thesis statement. It states that " $[\mathrm{t}]$ he thesis statement should have three devices that are common for both Prose and Baldwin. Example: Prose and Baldwin use , and to argue that "(1). Therefore, all the students have to do is fill in this template to construct their argument. The assignment sheet then proceeds to tell the writer what information should be included in each paragraph. While this directive approach does provide guidance to inexperienced and struggling writers, whom Owen has a lot of in AP English Language and Composition, it risks leading students to believe that college writing is about filling in templates and following precise directions, which is not the case in most instances. But

\footnotetext{
${ }^{72}$ See the appendix for Paper Assignment \#1.
} 
perhaps even more important, it limits the writer's choices and ownership over the work - two things that are strongly fostered in first-year college writing experiences. Yet, this approach does align with and is very similar with the methods employed in the popular They Say / I Say text by Gerald Graff and Cathy Birkenstein used in first-year writing courses. However, one part of this writing assignment does allow the writer to exercise choice and ownership. The assignment sheet explains that "[t]he fifth paragraph will deal with how their arguments could be improved. Neither Baldwin or Prose effectively provides a solution to their stated problems. Going back to your central thesis, explain how this central problem in education could be solved. In short, this is your turn to posit a solution and argue for its effectiveness" (1). So, students are asked to move, ever so slightly, away from the close readings of texts and formulate an argument in response to the authors. Practically, at this early point in the course, the students may be given an overview of organization for the paper because very little class time at this point has been directed towards the teaching of writing. In short, this first writing assignment focuses on close reading of the texts, becoming familiar with rhetorical strategies for analyzing texts, and demonstrating knowledge through writing.

While the first writing assignment associated with close reading asks students to perform a synthesis of two texts, the second writing assignment asks students to conduct a rhetorical analysis of a single text-George Orwell's "Shooting an Elephant". The assignment sheet states, "In a 3-5 page essay, explain how Orwell uses three (3) rhetorical strategies to exemplify and support what you believe his main thesis" (1). While students continue to have support from classroom instruction, this assignment is slightly more difficult because students are required to identify Orwell's main thesis. In 
contrast to the first assignment sheet, this assignment sheet lessens the direction that students are provided. For example, it says that "[t]he first paragraph should give a brief overview of Orwell's essay. Summarize the essay (approx. 3-4 sentences) as it relates to your thesis statement. Then provide a thesis statement you will argue throughout your essay" (1). Although students are still being told what type of information should be included in the introduction, as opposed to discussing the purpose behind an introduction and examining different approaches for achieving this purpose, they are given more freedom to read and summarize the text in relationship to their individual argument. Moreover, this assignment sheet does not provide a template that the thesis statement should follow; it just points out a thesis statement is a necessary component of the assignment.

It is also interesting to note that this assignment sheet, while still adhering to the 3.5 essay structure, draws attention to flow and issues of cohesion. It says, "Be sure to organize your argument so that each device builds on the previous device and leads into the following device being argued" (1). Additionally, focus on the structure of argument, outside of the number of paragraphs, comes into play for this assignment. For example, while directing students about the content of the second paragraph, the assignment sheet says that it "should discuss, in depth, the first rhetorical strategy Orwell employs to make his argument. You should use at least three (3) examples from the essay. Be sure to follow the format of analytical argument: statement, quote/evidence, explanation of quote, discussion of how quote/evidence proves/supports the thesis" (1). Aristotelian reasoning and logic are incorporated in this assignment, as students are also told to "pay attention to deductive and inductive reasoning" (1). These components are discussed on 
the assignment sheet and included in the scope and sequence for the course. These are terms and concepts that students are becoming familiar with and are using this assignment to practice. This inclusion is encouraging because it resembles what occurs in first-year writing courses, based on the inclusion of these concepts in multiple texts commonly used in first-year writing courses $^{73}$.

Similar to the second formal writing assignment in AP English Language and Composition at Red River High School, the third formal writing assignment asks students to compose another rhetorical analysis of a single text. For this assignment, students read Chris Hedges' essay "The Deconstruction of Culture” and "[i]n a 3-5 page essay, explain how Hedges uses three (3) rhetorical strategies to exemplify and support what you believe is his main thesis" (1). The overview for this assignment, and no doubt class discussion, indirectly directs students to construct arguments on certain topics or themes. For example, the overview for this assignment explains that "Chris Hedges' essay "The Deconstruction of Culture" offers many viewpoints on the effects of war. Hedges shows how human beings are conditioned to embrace what he calls 'the myth of war' - the idea that combat is noble, selfless, and glorious. The reality of war, which Hedges knows firsthand, is about the destruction of culture, the perversion of human desire, and the embrace, ultimately, of lies over truth" (1). Similar to the second assignment, students are required to identify Hedges' thesis and then construct a thesis statement about the ways in which the text uses rhetorical strategies to make the argument. However, the overview may lead students to develop a thesis that coincides with the themes already

\footnotetext{
${ }^{73}$ For example, In They Say / I Say, Gerald Graff and Cathy Birkenstein focus on connecting quoted material to the writer's these. Moreover, Writing Arguments by John D. Ramage and John C. Bean includes chapters on argument structure, as does Everything's An Argument by Andrea A. Lunsford and John J. Ruszkiewicz. These texts are chosen for comparison because they are often used in first-year writing programs at the University of Louisville.
} 
identified on the assignment sheet. This assignment does ask students to branch out from the text in the concluding paragraph because the fifth paragraph asks students to "summarize your analysis and relate how this theme is important to contemporary society"(1). So, even though students may be led to particular themes through the framing of this assignment, students are asked to engage with current issues, which align with the sponsorship of current events addressed in chapter three. Other than the difference in text, the assignment sheet for this assignment is identical to the assignment sheet for the second assignment. Once again, the assignment is setup to be completed using the 3.5 essay structure and specific instructions are provided for the information that should be included within each paragraph, which is potentially problematic as discussed above.

The fourth paper students complete aligns with a thematic unit on "gender roles, gender stereotypes, and the role society plays in establishing how we see ourselves as individuals" (Paper Assignment \#4). For this assignment, students return to synthesizing multiple texts and have some choice about which readings to synthesize. This assignment shows a notable increase in difficulty because it asks students to make informed choices about which texts to synthesize and how to connect the texts through a common theme. For example, the prompt states that students "will select either the male gender or the female gender to discuss in your essay...In a 4-6 page essay, synthesize your selected authors' ideas into one cogent, central thesis. Then, explain how they use rhetorical strategies to exemplify and support their shared claim" (1). Students are also provided with less direction on the assignment sheet in respect to templates, although they are directed how to pair the possible readings for synthesis. The assignment sheet is very 
direct in telling students that they “will either work with Theroux's essay and McMurty's essay, or...Woolf's essay and Tannen's essay" (1). And, this direction is repeated when explaining what is required in the thesis statement.

Additionally, students are still provided with an organizational frame that utilizes the 3.5 essay structure and an overview explaining the type of information that should be covered in each paragraph. For instance, the assignment sheet states that "[t]he first paragraph should give a brief overview of each author's main arguments. Then provide a thesis sentence that states a synthesized, central thesis that both authors (Theroux and McMutry or Woolf and Tannen) would agree on. Note: The thesis statement should have a central theme that is based in cause and effect. It DOES NOT need to have common rhetorical devices" (1). So, while students are still provided with direction, they have more options in terms of the direction that the synthesis takes and tailoring the analysis to the individual essays read for this assignment. Once again, and similar to assignments two and three, students are asked to branch out from the close reading of the text and connect their argument "to the larger social context of our times" (1). Even though the assignment provides tight boundaries, the skills that students are asked to demonstrate on this assignment relate closely to skills covered in first-year writing courses, such as close reading of multiple texts, synthesizing ideas, crafting thesis statements, and using textual evidence to support claims.

The four assignments discussed above ask students to perform close readings of texts and contribute to the focus on reading comprehension and reading strategies mentioned in the quotation opening this section. During this time in the course, which spans from the middle of September until the end of November, students in AP English 
Language and Composition at Red River High School are writing frequently and are composing papers of substantial length. Moreover, while the types of writing — synthesis and rhetorical analysis - do prepare students to compose genres that are included on the AP English Language and Composition exam, students also compose these genres in first-year college writing classes. In fact, AP English Language and Composition at Red River High School looks very similar to many first-year writing courses. Additionally, the types of writing assignments that students complete engage students in the kinds of activities and practices that the WPA OS encourage and in cultivating the dispositions that the Framework for Success in Postsecondary Writing identify and link with success.

\section{Released Exam Prompts}

In addition to students completing writing assignments that ask them to perform close readings identifying rhetorical elements of texts and synthesizing ideas, they also practice composing released exam prompts for the AP English Language and Composition exam. The syllabus for the course explains that "[a]t least five times every six weeks students will be required to write critical responses under timed situations" (2). During multiple observations, class time was devoted to reading and interacting with different types of essay exam prompts released by the College Board. While one such instance is included here, this instance is representative of multiple class sessions observed. During this particular class, students had already responded to the 2008 AP English Language and Composition Free-response Question (Form B) Question 1 and were led by Owen in a discussion focusing on the strategies and tactics that students used to negotiate the prompt, a discussion where Owen frequently interjected and modeled strategies and tactics that students neglected to mention. Throughout this lesson, Owen 
used questions, such as "What type of prompt is this?" "How is the prompt framed?" and "How did you organize the evidence?" to get students talking about strategies they used to answer the prompt and point out areas of struggle.

When the students were asked what was difficult, they responded with three issues that all centered on the sources provided with the question. Multiple students felt the sources "were not that good" and that made it difficult to use them to answer the prompt sufficiently. One student brought up that he had "a hard time figuring out what was important" and Owen used this opportunity to point out that the prompt provided a lot of source material, that "this is common in a lot of prompts" and they needed to "use the information that the prompt gives" to construct a response. Another student brought up the fact that he "could not figure out what was important and where to focus" and, to this, Owen responded that although it was difficult to sift through to figure out what was important and what could be discarded it was necessary. The students also pointed out that the sources seemed to be one-sided and leading them to argue for a specific position in their response. Owen conceded that these were all very good points and then proceeded to structure class around the concerns students pointed out. He continued to point out that they had to "use the information that the prompt [gave] them" in order to construct their response and this aspect made this type of writing different from the types of writing they would be asked to do in the future (in college) because, as he told the class, "not many classes will give you data to make your argument, you will have to find the data" through research.

Throughout this lesson, and other lessons, Owen made explicit references to the ways in which the writing strategies they were using to construct responses for released 
exam prompts could be used in other types of circumstances, such as writing the formal assignments for AP English Language and Composition or in the future for postsecondary writing tasks. For example, when one student asked "which side should you argue for a better response?" Owen responded that "there was not just one right answer because it is all in how you use the evidence to support the claim (Observation 3/13/2014). Additionally, Owen stressed the contrived nature of the writing task they were completing and the ways in which they needed to respond as writers and adjust their writing process because the AP English Language and Composition exam was a timed writing experience. For example, Owen explained that for answering a prompt, it was important to figure out a thesis quickly; however, when writing in untimed settings he pointed out that "you need to consider your thesis in light of your claims" and be prepared for "that thesis to change" as you write. Although, it is also true that learning how to write for timed exams is a useful rhetorical strategy for college writing because students will most likely be required to complete this type of writing at some point during their time in college.

Owen also focused attention on organizational patterns that could potentially assist students in responding to the prompt. For this particular prompt, he asks students: "how did you organize your response?" Answers varied but it became evident throughout the conversation that students writing more successful responses began writing with an organizational structure in mind. Because so many students did not approach the prompt thinking that having a structure would assist them in crafting a response, Owen provided two models that students might use for responding to this type of question. The first model he referred to as the "agree/disagree" where students would take a stance and 
support that stance with the sources provided. Generically, this model should produce five paragraphs, start with an introduction where the thesis statement is introduced, followed by two paragraphs where students address a topic and provide evidence from the sources, followed by a paragraph that presents a counter claim with evidence, and end with a conclusion that discusses the effect of the argument or makes a connection to contemporary society. The second option also is comprised of five paragraphs. It asks students to choose an option but qualify that choice. For this option, the first paragraph is an introduction with thesis statement, followed by a paragraph that argues for the option, the next paragraph argues against the option, followed by a paragraph that presents a middle of the road option, and a conclusion. While these forms appear to be a-rhetorical, Owen explains to students that this is an effective approach for composing a response for the exam because of the ways in which the reader is guided through the response. He also mentions the fact that, when writing outside of timed constraints, issues of audience are important to consider when making decisions about organizational structure. The focus on audience, Owen explains, is a driving force behind all choices that students must make when writing outside of timed constraints.

Both of these options prepare students to write 3.5 essays. However, given the constraints of the task, the structure of the 3.5 essay works rhetorically for this purpose. Yet, it would have been encouraging if Owen had pointed out the constraints of this structure. He did not during this particular lesson. Moreover, when I investigated many of the outside writing assignments, they too encouraged the adoption of the 3.5 essay format. It is troubling that so much of the course supported writing instruction for AP English Language and Composition appears to privilege this format, even outside of 
timed responses, when other, more rhetorically effective, options exist. Because of the troubling nature of the heavy emphasis seemingly placed on this aspect of writing instruction, I asked Owen about the types of organizational structures promoted in the writing instruction in AP English Language and Composition at Red River High School. He explained that the general writing instruction focuses on mastery of the 3.5 organizational format, and when students demonstrate competency and control over this format, they are encouraged to expand their organizational and structural possibilities. As Owen explained, by the time students are working on the fourth formal paper, he has "taught ...the 3.5 format. That is a basic format, so, this is a 5-6 page paper so you are not going to turn in 5 paragraphs... That's crazy talk. It is an...outline, an idea" and he explains to students that " if you want to explore and try new things out on this paper, please do...in effect... you will be rewarded. What I am looking at now is how are you organizing and developing an argument. It's that simple” (Interview 05 December 2014).

While I am not surprised by this approach because of the various levels of students enrolled in the course, the formulaic and contrived relationship this structure has to producing authentic work seems to work against the development of the dispositions and skills identified in the AP English Language and Composition course outcomes and in the Framework for Success in Postsecondary Writing, as addressed in chapters three and four. Furthermore, teachers and scholars at the secondary level are also arguing against teaching and emphasizing the 3.5 essay structure with students. For example, in Beyond the Five-Paragraph Essay, Kimberly Hill Campbell and Kristi Latimer explain how they were frustrated by the lack of critical thinking demonstrated in student writing following the 3.5 essay format. So, they "looked to the research and were stunned to find 
that research does not support literary essays taught in a five-paragraph formula" (3). Moreover, they point out that "the five-paragraph formula exists because we, as language arts teachers, accept the myths that support it" (4). They argue that teachers of writing (at the middle and high school level) "need to change how we structure our classrooms and how we support students as writers" (10). In short, while the 3.5 essay structure is included in AP English Language and Composition at Red River High School, Owen encourages students to move away from it as they develop as writers.

The next portion of the class was spent looking at the sources individually. Owen presented a series of questions that the students should ask about each source. These questions included:

- Where did it come from?

- Is the source of publication reputable?

- What do you get from the data?

- What is the effect of the data?

- Is the author biased?

Following this, the students were instructed to look for a common theme or thread among the sources but Owen cautioned that the sources are general and not specific because they are selected to give multiple jumping off points for a variety of arguments. This, then, broke off into a discussion about argument in more general terms. Owen pointed out that this writing task was different from the task of writing a research paper because it is under strict time constraints, students are not doing their own research, and must work with the sources that the exam provides. Students also realized, during this portion of class, that they can bring in outside knowledge in addition to the sources. 
Owen also brought the conversation back around to rhetoric at this point and stressed that rhetoric is "all about crafting an argument" and that it is a time tested method for making strong arguments. Students end this lesson with a clearer picture of where they need to focus in terms of structure and using sources.

It bodes well that, even though the AP English Language and Composition exam prompt that focuses on synthesis using research presents a restrictive and contrived task, the writing instruction surrounding the use of research follows practices found in Rhetoric and Composition scholarship and in first-year writing textbooks. For example, The Everyday Writer, $5^{\text {th }}$ edition by Andrea A. Lunsford ${ }^{74}$ provides nine criteria for evaluating sources. These include: purpose, relevance, level of specialization and audience, credentials of the publisher or sponsor, credentials of the author, date of publication, accuracy of the source, stance of the source cross-references to the source. And, many of these issues are addressed by Owen when discussing the use of sources with students in AP English Language and Composition. So, even though the exam is not asking students to conduct authentic research, the ways in which the writing instruction approaches the topic of incorporating sources follows practices supported by scholarship in Rhetoric and Composition and is similar to practices found in first-year writing.

The focus on practicing composing responses for released exam prompts leads students to feel prepared to take the AP English Language and Composition exam. Eighty-four percent of students ${ }^{75}$ strongly agreed and sixteen percent agreed that AP English Language and Composition prepared them to take the AP English Language and Composition exam. This is echoed in the confidence that the students exhibited when

\footnotetext{
${ }^{74}$ This text is chosen as an example because it is currently the recommended text for first-year writing at the University of Louisville.

${ }^{75}$ See chapter two for more information on the student participants.
} 
talking about how they thought they did on the exam after they had taken it. These feelings of preparation and confidence may be due to the structure of Owen's class, where students spent significant time learning about writing through composing released prompts for the exam. Students were very familiar with what to expect on the exam and were eager to express this during interview sessions. Paul told me that he was "pretty confident" about his performance on the exam (Interview 23 May 2014). Likewise, James was excited to share that he felt "really prepared, especially on the essay portion" (Interview 23 May 2014). Maria expressed a similar confidence in her level of preparation. She explained that she knew the steps and "how to tackle it" (Interview 23 May 2014). The way in which the course was structured most likely contributed to students feeling very well prepared for the exam. Thirty-two students out of eighty-nine passed the AP English Language and Composition exam by receiving a score of three or higher. This number indicates that, despite the fact that students spent a great deal of time on exam preparation and they felt as though they were being prepared to take the AP English Language and Composition exam, many students did not pass the exam, although they are, most of the time, making gains towards college readiness.

These outcomes indicate the dual purpose the course serves when enrollment is expanded and the goals are expanded to prepare some students for college and others to bypass first-year writing. Yes, the number of students enrolled increased but because so many students are coming to the course with scores several points under benchmark, the goal for nontraditional AP students shifts from passing the exam and towards progressing towards college readiness standards. This is also reflected below when many of the 
nontraditional AP student discuss their plans for enrolling in first-year composition when they enter their chosen postsecondary institution.

\section{Literary Analysis}

While the assignments discussed above all intersect with class discussions focusing on close reading, analysis of texts, and composing responses for essay questions included on the AP English Language and Composition exam, the students also compose written arguments in response to literary texts. It is interesting to note that, similar to when students began composing responses to the close reading writing assignments, the assignment sheets for the literary analysis writing assignments start off very detailed and become less detailed as time progressed. Issues of citation also come into play at this point in the course, as all three of the literary analysis assignments require students to "cite the page number of each example using MLA format" (bold original 1). Even though students are not conducting research and are only pulling from the primary text to complete each of these assignments, the importance of citation and citation practices are introduced to students. This is an encouraging practice that connects with practices that occur in first-year writing courses. For example, in the Knowledge of Conventions section of the WPA OS states that students will "Practice applying citation conventions systematically in their own work".

Moreover, it is important to note that plagiarism detection software also begins to be utilized at this point in the course. The first literary analysis assignment, The Great Gatsby Paper Assignment, explains to students that "you will have to run your paper through TurnItIn.com and print out and/or forward the report to me to prevent any plagiarism and insure the originality of your work" (bold original 1). The rest of the assignment sheets merely state that students "will have to run your paper through 
TurnItIn.com" (bold original 1). As discussed in chapter five, the use of this type of software is not encouraged in first-year writing courses at many institutions, even though it is used by other courses in postsecondary institutions.

Because of the misalignment concerning the use of plagiarism detection software, I asked Owen why he utilized this type of program as part of his pedagogy. He explained that the 2013-2014 school year was the first and only time that he used plagiarism detection software in a class focused on writing instruction. He explained that he originally implemented the policy of having students submit formal writing assignments to Turnitin.com because of several instances of plagiarism. Moreover, Owen was also trying to negotiate teaching almost three times as many students in AP English Language and Composition under Red River High School's involvement in Advance Kentucky and experimented with plagiarism detection software as measure to prevent cheating. However, Owen was dissatisfied with the results. He explains in a follow-up interview, "I don't use it, because like I said, it is a waste of money, it doesn't work, and I think it sends the message of we are going to play cops and robbers... It was doing what we don't want to do as writing instructors and that is turning writing into a formulaic game to play. It takes, as cheesy as it sounds, it takes the artistic element out of" writing (Interview 05 December 2014).

Even though the use of plagiarism detection software is out of alignment with the practices of first-year writing, it was only used during this one year, and, more importantly, the literary analysis assignments resemble writing tasks that students are asked to complete in some first-year writing courses. For the first literary analysis assignment, the overview explains that students will "have read F. Scott Fitzgerald's The 
Great Gatsby, now it is time for you to analyze Fitzgerald's use of rhetoric and/or literary devices to develop a central theme. While there are numerous themes prevalent in this novel, you need to be able to develop a central thesis that critiques/analyzes how Fitzgerald supports one of these" (1). In response to this, students will compose a 5-7 page analysis of the text. Similar to the close reading assignments that students completed during the first half of the course, the assignment sheets are directive in terms of what types of information should be placed in each paragraph. For example, the assignment sheet explains that "[t]he first paragraph should give a brief summary of the novel. This should not be an over-arching, subjective plot summary that encapsulates the entire novel. You will provide a brief, objective (no more than 10 sentences) summary of the novel that relates to your thesis. Then provide a thesis sentence that states a central thesis. Note: The thesis statement should have a central theme based in cause and effect" (1). Therefore, students are still limited in terms of authorial ownership in structuring their writing. It appears as though the directive nature of assignment sheets, such as this one, compartmentalizes writing into a series of checklist and students can complete the tasks laid out before them for each paragraph, mark them off, and move on to the next series of checklists for the following paragraph. This formulaic approach is potentially problematic because it directs and exerts control over the ownership of the texts being produced and neglects to allow students the opportunity to experiment and experience composing in authentic ways ${ }^{76}$.

\footnotetext{
${ }^{76}$ Standardized authentic writing assessment may take the form of a writing portfolio. As early as 1989 David Foster argued that both AP English courses should "Allow previously composed and revised essays to be submitted in partial fulfillment of the essay portion of each examination" (21). In 2001, Joseph Jones also calls for a portfolio to become part of the AP English assessment process.
} 
Although the continued directive nature of the assignment sheets have the potential to be troubling, it is interesting that the thesis statement is one area that is always addressed at some level. For this first literary analysis, students are told that they need a thesis and the purpose it should serve. They are also given an example of a possible thesis statement on the assignment sheet but also a caution that their individual thesis statements will need to be more specific. For instance, the example provided states that: "Fitzgerald uses characterization, symbolism, and imagery to illuminate the struggles people face to develop an individual identity because of demands placed on them by society" (1). However, this example is followed up with a discretionary note that "[t]he above thesis is very broad...your thesis needs to be more objective/specific as to the causes and effects than what is written above" (1). Therefore, this assignment prompt provides a model thesis statement but also cautions students that the model is imperfect and encourages them to construct stronger thesis statements.

While the first literary analysis prompt requires that all students read a single text, the second literary analysis prompt allows students to select between two literary textsRay Bradbury's Fahrenheit 451 or George Orwell's 1984. Other than the expanded text selection and the omission of an example thesis statement, this assignment sheet is almost identical to the assignment sheet for the first literary analysis. Moreover, the third literary analysis also largely follows the same format with three slight changes. The first notable change is the length for the third literary analysis. For this assignment, students are asked to compose 6-8 pages. The second notable change is that there are five text options for the students to select from: Franz Kafka's The Metamorphosis, Katherine Dunn's Geek Love, Virginia Woolf's Mrs. Dalloway, Kurt Vonnegut's Slaughterhouse Five, or 
Richard Wright's Native Son. The third notable change has to do with the construction of the thesis statement for this assignment. Similar to the second literary analysis assignment, there is no example given. However, the assignment sheet does advise students that they "need to make sure your thesis is specific and not a recycled from a previous paper" (1). Although students would most likely not be asked to compose multiple literary analysis papers in a first-year college writing class, this series of assignments grants them practice with composing arguments, working with texts, crafting thesis statements, developing claims to support the thesis statement, locating evidence to support claims, and citing sources, all of which are included in first-year college writing courses. So, these assignments allow students practice with the types of writing skills that they will be asked to complete in first-year writing courses when they enter postsecondary institutions, despite any tensions that exist in the ways in which the writing instruction is approached.

The writing instruction included in AP English Language and Composition at Red River High School appears to be very effective in preparing students for the types of writing that they will encounter on the AP English Language and Composition exam, due to the fact that so much class time is spent on writing instruction for this purpose and students practice composing in this genre through completing 46 released prompts. Additionally, the other types of writing assignments — close readings of texts that requires students to perform rhetorical analysis and synthesis and literary analysis—prepare students for some of the types of writing assignments that they will be asked to complete in college and resemble assignments that are given in first-year composition. However, the ways in which certain aspects of the writing instruction is approached in AP English 
Language and Composition are in tension with the ways in which writing instruction is approached in first-year composition. And, these places of tension could possibly lead students to have false expectations of the ways in which writing instruction is approached in postsecondary institutions because the writing instruction provided in the AP English Language and Composition course leads students to believe that teacher provided templates and formulas, 3.5 essay structures, and the use of plagiarism detection software are important parts of the writing process. Thus, students have the potential to enter postsecondary writing courses expecting these things to lead to success because they were successful in a course that presents itself as "designed to provide high school students the opportunity to engage in a typical introductory-level college English curriculum" (Course Description 8). In short, students are working with skills that are similar to those found in first-year writing courses but the type of instruction differs.

\section{Rhetoric in AP English Language and Composition}

In addition to writing instruction, analyzing the rhetorical choices that authors make plays a large role in the type of writing assignments that students complete. While there is no doubt on the part of the College Board or Owen that AP English Language and Composition is a rhetoric course, students expressed a range of attitudes concerning whether or not they actually understood rhetoric. This range of understanding is reflected in student interviews. For example, Paul and James were confident that they had a strong grasp of rhetoric after completing the course. James explains that "rhetoric is a way of structuring or using different forms of writing to strengthen your appeal or strengthen your argument" (Interview 23 May 2014). Likewise, Paul explains that "now...[he] understands what writing is about" because he now understand how rhetoric operates in 
other people's writing and in his own writing (Interview 23 May 2014). Now, while James and Paul are confident that they understand rhetoric after taking AP English Language and Composition, other students are not as sure. Aliyah explains that she is "a little bit closer than...[she] was at the beginning of the year...[because now she] can pick things out and start to interpret" (Interview 23 May 2014)). Patrick also feels more comfortable. He explains that he "wouldn't say... [he] fully understand[s] it...but..[he's] learned a lot about it" (Interview 23 May 2014). Laura explains that she has "gotten a lot better with it" over the course but still has things to learn (Interview 23 May 2014). Similar to Laura, other students express their experience in terms that indicate they may still be developing comfort. Matthew explains that he "didn't have a clue was it was... now... [he] can list a ton of rhetorical devices and... [he] knows how to pick up on them" (Interview 23 May 2014). Yet, there are also a few students who are unsure what rhetoric means. Jasmine explains that she did not know what the term meant before starting this class and she is still not sure but they've used it a lot and she has had a lot of practice looking for rhetorical devices. Likewise, Alexis explains that it was a new concept and she is still confused by it at times. As the students reflect on their understanding of rhetoric, it becomes apparent that they seem to fall along a continuum of understanding when it comes to rhetoric. In short, despite the fact that there is a clear rhetorical component to the course as described by the documents produced by the College Board and Owen clearly incorporates and emphasizes rhetoric in the course, rhetoric is such a loaded and complicated concept that some students seem to still need additional time and instruction to strengthen their comfort level. 
I talk to these kids all the time about do I want you to pass the exam? Sure. For you, I want you to pass. You put all this work in for...32 weeks. Yes, I want you to pass but if you don't, my big thing is that I don't want to see ones because a one indicates that you probably didn't get much, if anything out of the course...A kid gets two, fine. Because that kid has at least an initial handle and they are not going to completely die when they go to college when have to write. A kid gets a three, four, or five on an AP exam in this class, I am confident they can write in college.

Owen (Interview 20 March 2014)

\section{Students' Perceptions About Writing In Postsecondary Education}

Students are composing a lot in AP English Language and Composition at Red River High School through performing written close readings of texts, responding to released practice essay prompts, and conducting out of class literary analysis essays. And because of this intense focus on writing, many students feel prepared for the writing tasks they will be asked to complete in postsecondary writing courses. At the end of the course, eighty-eight percent of students strongly agreed and twelve percent of students agreed that AP English Language and Composition prepared them for college-level writing tasks. This was echoed in interviews. As Matthew explains, the class is supposed to "prep them [students] for college; show them what it is going to be like" (Interview 23 May 2014). Ada agrees with Matthew when she explains that she thinks the purpose of the class is to "prepare them [students] for college... and to be a better student" (Interview 23 May 2014). Aliyah agrees with Ada and Matthew. She tells me that she feels the purpose of the class is "to prepare for college" (Interview 23 May 2014). James also agrees that "it should prepare you to do, like, academic writing; to write in college" (Interview 23 
May 2014). Although this is an interesting perception, students enrolled in AP English Language and Composition at Red River High School do not actually know what college writing courses will be like. They are basing their perceptions off what they have been told about AP English Language and Composition preparing them for college writing and imagined possibilities for first-year college composition. In short, students in AP English Language and Composition at Red River High School feel prepared to write in college, but they do not know this for a fact. Moreover, although there are many (many) positives concerning the writing instruction in AP English Language and Composition at Red River High School, it is potentially problematic that these students believe that this course prepares them for college writing when tensions and contradictions exist between the writing instruction occurring in AP English Language and Composition, practices of first-year college writing courses, and scholarship on first-year college writing. However, while these tensions and contradictions cannot be denied at certain points, the writing instruction, overall, in AP English Language and Composition at Red River High School is preparing students for college writing through rigorous coursework, challenging assignments that resemble assignments given in first-year writing courses, and, at the very least, in preparing students to work independently outside of class using time management skills and negotiating workloads.

It is also promising that explicit references to future writing contexts are included in the writing instruction because this allows students to imagine future possibilities when they may need to employ the writing skills that they are using to address the released prompts. These discussions also move the writing instruction within the class outside of the constraints of writing within a rigid prompt and stylistic limitations caused by a timed 
assessment. Despite the fact that so much writing is focused on composing responses to released exam prompts and the formal assignments were directive in nature and, at times, contradicted the practices of first-year writing, students were able to see connections between what they were doing in AP English Language and Composition and what they expected to be doing in first-year college writing. In fact, forty-eight percent of students strongly agreed that there were connections between the two courses and forty-four percent agreed that connections existed. Students also brought up this connection during interviews. Paul asserts that he really believes this course is similar to first-year college writing because they are building a foundation for their writing skills (Interview 23 May 2014). Katie sees connections between her expectations of first-year college writing and AP English Language and Composition because they are covering the "basic fundamentals of writing" like thesis statements, claims, introductions, and conclusions, all things she anticipates a first-year college writing class to cover (Interview 23 May 2014). Patrick also sees similarities between AP English Language and Composition and what he anticipates would be covered in a first-year college writing class. He explains that they do "a lot with reading essays, writing, citing, finding evidence," and, from what he knows about first-year college writing, he feels these are some of the skills that are covered in those courses (Interview 23 May 2014).

It is encouraging that the majority of students at Red River High School do not see the AP English Language and Composition as a replacement for first-year writing. This is encouraging because it shows that the course is viewed as a way to better prepare for the writing that will be assigned in college. Forty-eight percent of the respondents strongly agreed that they plan on enrolling in some type of first-year writing class during 
their first year at college. And, forty percent agreed that they would enroll in some type of first-year writing class during their first year at college. When considering this data in light of students meeting college readiness benchmarks in English and Reading, it is not surprising that many students feel they need additional writing instruction when they enter college, given that many students moved to being college ready in English and Reading during the course of taking AP English Language and Composition and some students have still not achieved college readiness. Additionally, students made reference to enrolling in first-year college writing. Laura, a senior, revealed that she had already registered for a first-year writing class at the postsecondary institution that she would be attending in the fall because, while she learned a great deal from this course, she (and her mom who is a high school English teacher) felt like she would benefit from additional writing instruction (Interview 23 May 2014). Similarly, Shawn "feels ready for a college level English class" and feels he will do well in first-year composition after having completed AP English Language and Composition (Interview 23 May 2014). Moreover, this also aligns with Jolliffe and Phelan's argument in "Advanced Placement, Not Advanced Exemption: Challenges for High Schools, Colleges and Universities" when they argue that AP English "courses can be most appropriately seen as transitions from high school reading and writing instruction to the same at the college level” (89). However, not all students share the belief that enrolling in first-year composition during their first year of college would be helpful.

Whereas Laura and Shawn saw AP English Language and Composition as preparing them to enroll in first-year writing in college, some students that identified as the type of students traditionally served by AP Language and Composition did express 
the hope that they would be able to bypass first-year writing. Matthew traced his initial interest in the class because of the potential for college credit. He explains that he wanted to "push...[himself] because... [he] could possibly get college credit out of it" (Interview 23 May 2014). James and Hunter also see themselves bypassing part or all of the firstyear college writing requirement when they enter college, James explains that the course "should prepare you to do academic writing, to write in college... [much like a] college level English course" (Interview 23 May 2014). On a similar note, Hunter asserts that he was pretty confident that he scored "at least a three" on the AP English Language and Composition exam and therefore would receive some college credit as long as he sticks with his plan to attend a public institution in Kentucky. The attitudes and beliefs expressed by Matthew, James, and Hunter are more aligned with traditional configurations of AP that view the course as a precollege credit for writing alternative. However, these students are only buying into the promises made by the College Board and traditional attitudes concerning the purpose of completing AP coursework as a way to bypass general education courses ${ }^{77}$.

The AP English Language and Composition course is clearly marketed as way to earn college credit. The first page of the Course Description states that "Strong performance on AP Exams is rewarded by colleges and universities worldwide. More than 90 percent of four-year colleges and universities in the United States grant students credit, placement or both on the basis of successful AP Exam scores" (1). The Course Description also states that "although the specific college courses that AP credit will satisfy will differ from college to college, each exam represents a year's college-level

\footnotetext{
${ }^{77}$ While Jolliffe and Phelan and others in Rhetoric and Composition see AP English as a placement tool, they are in the minority.
} 
work" (4). This language lends to an interpretation of the course that favors AP English Language and Composition as a replacement for first-year writing, rather than as means for increasing college readiness and preparing students to enter first-year writing courses when they enter their postsecondary institutions. Yet, as this chapter demonstrates, AP is currently being used to perform both functions through Advance Kentucky.

\section{Conclusions}

The participation in Advance Kentucky and push to enroll more students of various academic levels in AP English Language and Composition at Red River High School is heavily influenced by conversations concerning college readiness. While not a new concept, as discussed in chapters three and four, an increased focus on college readiness accompanied the adoption of the Common Core State Standards in 2009 and the term college readiness became more concretely defined as certain benchmark scores achieved on standardized assessments. The rigorous pace and challenging curriculum of AP English Language and Composition at Red River High School assists students in moving towards, and in many instances achieving, benchmark scores in English and Reading. While the course is designed to prepare students for the exam, this preparation also seems to influence students' advancement towards college readiness standards as measured by the ACT. As discussed in this chapter, students enrolled in AP English Language and Composition at Red River High School had average English gains of 4.37 and the number of students not college ready decreased from thirty-eight to six in this area. Moreover, these same students had average reading gains of 2.75 and the number of students not college ready in this category decreased from forty-seven to seventeen. These increased scores and the college readiness label are important because they allow 
students to have more options. Whereas before enrolling in AP English Language and Composition, many of these students would have been placed into developmental writing at a community college and not granted acceptance in four-year institutions such as the University of Louisville and the University of Kentucky. These students now have options and will not need remedial coursework when they enter postsecondary institutions. The case study of Red River High School presents one way of decreasing the need for remediation in college by focusing on innovative and proven ways to increase college readiness while students are still enrolled in high school. Students meeting college readiness benchmarks at the end of the junior year are also at an advantage because they do not necessarily have to retake the ACT as seniors and definitely do not have to complete alternative assessments to measure for college readiness. This means they can focus more on making informed decisions about their postsecondary education. Additionally, the large gains experienced by students enrolled in AP English Language and Composition at Red River High School support arguments and research on the rigors of AP coursework and it helping to better prepare students for college.

In short, this case study shows AP English Language and Composition effectively serving as both as a site for precollege credit for writing and as a site associated with preparation for college readiness, despite the tensions that arise between the writing instruction included in this course and the writing instruction promoted in Rhetoric and Composition scholarship and fostered in first-year writing courses. Students entering postsecondary education after taking this course at Red River High School are equipped with experiences in writing instruction that will prepare them to be successful in their postsecondary writing tasks. For the small percentage of students seeking to bypass first- 
year composition, these students will enter with experiences similar to experiences fostered in first-year writing courses. They will have been sufficiently prepared to craft solid arguments through instruction and practice with thesis construction, claim development, evidence selection, citation conventions and revising their writing. Moreover, the much larger percentage of students indicating plans to enroll in first-year composition will enter with a firm foundation of writing instruction and be able to continue growing as writers with the additional instruction that first-year writing courses will provide. Both types of student—-traditional and nontraditional—will enter postsecondary education with a solid foundation of writing instruction after having already completed a variety of college-level assignments under conditions similar to the conditions fostered in first-year writing courses.

In addition to demonstrating the ways in which AP English Language and Composition prepares both traditional and nontraditional students for postsecondary writing experiences, this case study continues to highlight the diversity of practice found in the course. While Owen is bounded by the same foundational documents and boundary objects as Stella at Violet Fields High School and William at Blue Meadows High School, AP English Language and Composition at Red River High School is very different from these other locations. So, in addition to showing the ways in which AP English Language and Composition can be used to prepare students for postsecondary writing experiences, this case study also draws attention to the diversity of practices within the course at different locations. 
CONCLUSION: INVESTIGATING PRACTICES IN AP ENGLISH LANGUAGE AND COMPOSITION LEADS TO REIMAGINING POSSIBILITIES

AP isn't going away, so we need to pay attention. And, when we pay the kind of attention as I did in this study, even with only case studies of three schools, we see a variety of practices and experiences. As more students come to college with this as their writing classroom experience, it has important implications for college and high school classrooms, teachers, and policies. Because the AP program is continuing to expand, and increasing participation among all types of student populations is a state goal, I argue that there needs to be more awareness in how these courses are functioning in particular locations and how students are being prepared for postsecondary writing experiences. James Warren points out that "One of the few points on which AP English critics and defenders agree is the need for more collaboration between college writing programs and AP English programs" (79). This means that teachers of writing on both sides would benefit from knowing more about students' past experiences and the expectations of future experiences. In short, this dissertation begins to investigate the daily practices and experiences that students enrolled in AP English Language and Composition experience at different locations within a single school district.

\section{A Variety of Course Experiences in AP English Language and Composition}


In addition to work concerning literacy practices and sponsorship, work in actornetwork theory, especially the idea of the boundary object, played an important role in investigating the experiences found in AP English Language and Composition. Tara Edwards and Richard Fenwick quote Star and Griesemen in arguing that "boundary objects are: 'plastic enough to adapt to local needs and the constraints of the several parties employing them, yet robust enough to maintain a common identity across sites"” (50). This is important for this project because viewing the AP English Language and Composition outcomes as a boundary object operating differently in different locations and informed by the WPA OS allows the examination of the ways in which the course is being enacted in particular locations. As Fenwick and Edwards explain, "Positioning learning objects as tokens or boundary objects provides ways for researchers to trace their particular uptakes and fallings apart, even as they might be used to spread a unified curriculum across space and time" (79). While the College Board does regulate and oversee AP English Language and Composition through Advanced Placement Summer Institute trainings, common course outcomes, syllabi audits, released prompts, and examinations, the individual uptake of the course varies from location to location based on the "human and non-human entities" available to the individual networks, as the three case studies included in this dissertation demonstrate.

Similarly, objects, such as the WPA OS and/or the outcomes for AP English Language and Composition, can only shape actions in particular locations. Fenwick and Edwards assert that "an object that is taken to be singular is, in fact, often performed in different ways" (37). Because AP English Language and Composition is regulated and supervised by the College Board, the assumption exists that the course is executed in 
similar ways at different locations. While it is true that all AP English Language and Composition courses must be approved by the College Board through an audit process, this dissertation has shown that the actual enactment of the approved curriculum operates vastly differently based on location, teacher, types of students enrolled, and resources available. For example, students at Violet Fields High School are conducting research based assignments in a university library, while students enrolled in the same course at Blue Meadows High School only compose responses to released exam prompts and mainly focus on test preparation. In short, it is extremely important to recognize the relationship between the particular locations - their histories and resources—and the practices observed in AP English Language and Composition. In attempting to understand what students experience in AP English Language and Composition, the practices could not and cannot be divorced from the location. To argue that all AP English Language and Composition courses are alike neglects the reality of what is actually happening at unique locations with unique teachers and students.

Although AP English Language and Composition is guided by the College Board and its enactment is bounded by the outcomes statement, the ways in which it is enacted at individual locations is heavily influenced by the material resources available, the history and philosophy of the teacher, and the background and future goals of the students enrolled. The three case studies included in this dissertation show the varied experiences that students coming out of AP English Language and Composition experience. AP courses, in certain locations, continue to serve the best and the brightest, while in other locations AP courses are serving a dual purpose by offering challenge to advanced students ready for college-level coursework and providing rigorous material for 
students in need of remediation so that they can achieve college readiness. The case study of Violet Fields High School demonstrates that the rigor and challenge associated with this particular AP English Language and Composition course are unique to the specific location. Moreover, the writing instruction and course experiences at Violet Fields are very similar to the instruction and experiences in many first-year composition courses. This location also does an outstanding job at promoting the dispositions identified in the Framework for Success in Postsecondary Writing; however, it is important to note that many of the students enrolled in this course were already making significant progress towards the development of the dispositions identified for success. The case study of AP English Language and Composition at Blue Meadows High School shows a rigorous and challenging course that prepares students to take the exam but neglects to offer an experience that is similar to first-year writing. The case study of Red River High School shows the ways in which AP English Language and Composition has the potential to perform the dual function of serving as a precollege credit for writing alternative and as a way for students to become college ready. Moreover, the writing instruction and course experiences at Red River High School demonstrate the innovative uses of older programs, such as AP, to meet the needs of current students. Furthermore, teachers of writing at the postsecondary level need to realize that students are entering first-year writing classrooms with a variety of experiences, including having completed rigorous courses such as AP English Language and Composition, and are at various levels of writing development.

As this dissertation shows, teachers of AP English Language and Composition are relying on the College Board to keep them informed about the practices of first-year 
writing. And, as Kathleen Puhr points out, from an outcomes standpoint, there is a great deal of similarities between the courses. However, the ways in which the teachers approach meeting the outcomes and the instructional strategies they employ when teaching writing often can fall outside the scope of practices found within first-year writing classrooms, as is addressed in chapters five, six and seven.

\section{AP English Language and Composition Serves Multiple Purposes}

In the current educational landscape, AP English Language and Composition is reimagined to fulfill a variety of purposes, even though it continues to remain one of the most common ways that students earn precollege credit for writing completed in high school. With the push at local, state, and national levels to increase the number of students enrolled in AP coursework, AP must break out of its traditional role in catering to gifted and advanced students. While this goal of increasing access to AP is admirable, it is not without problems. Tim Lacy argues that "Over time the program became less concerned with keeping smart students from being board and more involved — to its credit — in the democratic ideal of increasing access to high-level coursework for able, motivated students" (41). However, Chrys Dougherty and Lynn T. Mellor question whether or not it is a responsible practice to increase AP enrollments, especially with students not prepared for the rigorous coursework and still striving to achieve college readiness benchmarks. They claim that "the problem of college readiness is a key issue for AP: since properly taught AP courses are college-level courses, a student should be college ready in the relevant subject on day one of an AP course in order to be adequately prepared for the course" (220). Yet, this attitude neglects to look at the multiple functions that AP courses are playing in the current educational landscape and makes the false 
assumption that all students are enrolling in AP courses in order to attain college credit. The interviews and survey data collected from Red River High School, where a great many of the students are not college ready on day one of AP English Language and Composition, indicate that students do not view the course as a replacement for first-year composition, but as preparation so that they will be better equipped to succeed when they enroll in first-year composition when they enter their chosen postsecondary institution. While Dougherty and Mellor argue that "A focus on the goal of college readiness for the majority of disadvantaged students requires early intervention, ideally in preschool and elementary school, to place those students on a path to college readiness" (225), they neglect to mention what should be done to assist students that did not receive those early interventions. Yet, as chapter seven examines, programs such as Advance Kentucky provide the necessary support so that students not yet meeting college readiness benchmarks can enroll in AP English Language and Composition and experience success and growth.

This dissertation also examines the relationship between AP English Language Composition and college readiness indicators, such as the cultivation of dispositions identified as being important for postsecondary success and standardized assessment benchmarks. As chapters three and four point out, the eight habits of mind identified in the Framework for Success in Postsecondary Writing - curiosity, openness, engagement, creativity, persistence, responsibility, flexibility, and metacognition — are all fostered in the AP English Language and Composition courses participating in this study, even though some dispositions are more central to the course than others and the emphasis on certain dispositions depends heavily on the teacher. In short, students enrolled in AP 
English Language and Composition are provided with a variety of experiences that offer them preparation for postsecondary writing experiences. Additionally, this is also indicated by the growth that the students at Red River High School experienced in regards to ACT English and Reading scores after enrolling in AP English Language and Composition.

\section{Implications for Policy and Pedagogy in AP English Language and Composition \& First-Year Composition}

AP English Language and Composition teachers are at an advantage for preparing their students for postsecondary writing experiences because the outcomes for the course overlap so heavily with the WPA $O S$. Why not focus on making all secondary high school English teachers familiar with the WPA OS and the skills and practices that students will need for successful college writing experiences? As described in chapters three and four, the Framework for Success in Postsecondary Writing attempts to make this important move. However, without the proper resources and support from the school, district, and state levels, teachers will not be able to implement meaningful changes.

As explored in chapters three and four, the curriculum associated with AP English Language and Composition does promote the cultivation of dispositions that have been linked to postsecondary success. However, as literacy educators, we must ask ourselves why these dispositions are not actively fostered in every English course that every student takes. Why does a course have to be labeled "Advanced Placement" in order for students to experience a challenging and rigorous curriculum?

\section{Limitations and Areas for Further Research}


This study is limited by the small sampling of participants. The voluntary participation of teachers is also a limitation. Because teachers self-selected to participate, many of the teachers that contacted me were very excited to share their practices. However, teachers of AP English Language and Composition that did not feel as though their courses were comparable to first-year composition may have chosen not to participate in this study. On a similar note, the investigations of this project were limited to the resources that the teachers were willing and able, because of material constraints, to share with me. This study may also be limited by the type of school district in which I observed. The enactment of AP English Language and Composition may differ in private schools or in rural areas of the state because of differences in resources, culture, teacher histories, and students' background and goals.

The work contained in this dissertation only begins to slightly address the practices occurring in AP English Language and Composition. The next step is expanding the investigation to include additional AP English Language and Composition classrooms, both inside and outside Jefferson County in public and private secondary schools. While the three case studies-Violet Fields High School, Blue Meadows High School and Red River High School—provide rich sources of material, these schools represent three distinctly different types of schools—one school that has a longstanding tradition of excellence in student achievement, one school with a demonstrated record of solid achievement, and one school trying to increase student performance and move out of the classification as struggling. Therefore, for a more thorough investigation, AP English Language and Composition courses at additional types of schools need to be examined. 
The time in which I had to complete this study was limited by the time-frame of my dissertation schedule. Therefore, I was only able to actively collect data and observe in AP English Language and Composition for a single semester and not for the entire course. Moreover, by the time that I had all of the appropriate approvals from IRB and Jefferson County Public Schools, it was late February. I was also constrained by the schedules at the individual schools, as end of course exams, other AP exams, and special student programs and events were scheduled frequently during the end of the school year. Perhaps the most exciting next step for future research involves following students from AP English Language and Composition into their chosen postsecondary institutions to follow their experiences with writing in college. This includes both students that enrolled in first-year college writing and students who bypassed the first-year writing requirement by achieving a passing score on the AP English Language and Composition exam. Although it may prove to be difficult to follow students down multiple paths, the only way to definitively assess the ways in which secondary students are prepared for writing in postsecondary institutions is to allow them the time and space to matriculate and follow-up to investigate their successes and failures.

Another possible line of inquiry that has developed from this project concerns examining the connections between the Framework for Success for Postsecondary Writing and other types of precollege credit for writing alternatives. Because the Framework establishes itself as a foundational document for preparing students to succeed in postsecondary writing experiences, it can be used to examine the similarities and differences between the knowledge and dispositions that it outlines and programs such as dual-credit college composition and writing courses included in the International 
Baccalaureate program. There is also potential for the Framework to be used to examine the ways in which regular secondary English courses prepare students for postsecondary writing experiences.

A common thread in the discussion of AP English Language and Composition is how the course fits into the landscapes of precollege credit for writing alternatives as a replacement for first-year writing. While many colleges and universities are reevaluating the ways in which they award college credit for AP exam scores, it is important to remember, and as is shown in this dissertation, the course holds value beyond the possibility of fulfilling a first-year writing requirement. Students are learning valuable foundational writing skills and are provided with opportunities to cultivate dispositions associated with later college success though participating in a well-designed and effectively taught AP English Language and Composition course. 


\section{REFERENCES}

A Brief History of the Advanced Placement Program. College Board Inc., 2003. Web.30 Jan. 2015.

ACT. The Reality of College Readiness |2012 Kentucky. ACT, n.d. Web. 2 Oct. 2014.

Adler-Kassner, Linda, and Heidi Estrem. "Reading Practices in the Writing Classroom." Writing Program Administration 31 (2007): 35-47. Print.

Advance Kentucky ..accelerated learning Advance Kentucky / Kentucky Science and Technology Corporation, 2014 Web. 30 Jan. 2015.

Albertson, Kathy, and Mary Marwitz. "The Silent Scream: Students Negotiating Timed Writing Assessments.” Teaching English in the Two Year College 29 (2001): 144153. Print.

AP Central. College Board Inc., n.d. Web. Sept. 2014.

AP English Course Description: English Language and Composition, English Literature and Composition. College Board Inc., 2010. Web. 3 Feb 2013.

Barnett, Timothy, ed. Teaching Argument in the Composition Course: Background Readings. Boston: Bedford/St. Martin's, 2002. Print.

Bartholomae, David, and Tony Petrosky, eds. Ways of Reading: An Anthology for Writers. Boston: Bedford/St. Martin's Press, 1996. Print.

Barton, David, Mary Hamilton, and Roz Ivanic, eds. Situated Literacies: Reading and Writing in Context. London: Routledge. 2000. Print. 
Behm, Nicholas N, Gregory R. Glau, Deborah H. Holdstein, Duane Roen, and Edward M. White, eds. The WPA Outcomes Statement a Decade Later. Anderson, S.C: Parlor Press, 2013. Print.

Berlin, James A. Rhetoric and Reality: Writing Instruction in American Colleges, 1900 1985. Carbondale: Southern Illinois University Press, 1987. Print.

Beshear, Steve. "Architecture for Implementing the Common Core Standards: Strategies, Partnerships \& Progress.” Marriott Louisville Downtown Hotel. Louisville, Kentucky. 28 Feb. 2012. Speech.

Bradbury, Ray. Fahrenheit 451. New York: Simon \& Schuster, 2003. Print.

Braddock, Richard R. Research in Written Composition. Champaign, IL: National Council of Teachers of English, 1963. Print

Brandt, Deborah. Literacy in American Lives. Cambridge: Cambridge University Press, 2001. Print.

----“Sponsors of Literacy.” CCC 49.2 (1998): 165-185. Print.

Bromley, Karen. "Nine Things Every Teacher Should Know about Words and Vocabulary Instruction.” Journal of Adolescent and Adult Literacy 50 (2007): 528-537. Print.

Brown, Lyn Mikel, and Carol Gilligan. Meeting at the Crossroads: Women's Psychology and Girls' Development. Cambridge: Harvard University Press, 1992. Print.

Campbell, Kimberly H, and Kristi Latimer. Beyond the Five-Paragraph Essay. Portland, ME: Stenhouse Publishers, 2012. Print.

Carey, Bridget. "The Rise of Text, Instant Messaging Vernacular Slips into Schoolwork." The Miami Herald 6 Mar. 2007. Web. 4 Feb. 2015. 
Chalmers, Gordon K. "Advanced Credit for the School Student." College Board Review 18 (1952): 309-312. Web. 15 Apr. 2013.

Chiseri-Strater, Elizabeth. Academic Literacies: The Public and Private Discourse of University Students. Portsmouth, NH: Boynton/Cook, 1991. Print.

Cho, Yeonsuk. “Assessing Writing: Are We Bound by Only One Method?” Assessing Writing 8 (2003): 165-188. Print.

Cintron, Ralph. Angels’ Town. Boston: Beacon Press, 1997.

Cohen, Samuel S., ed. 50 Essays: A Portable Anthology. Boston: Bedford/St. Martin's, 2004. Print.

Common Core State Standards. National Governors Association Center for Best Practices and Council of Chief State SchoolOfficers. 2015 Web. 30 Jan. 2015.

Connors, Robert J. Composition-Rhetoric: Backgrounds, Theory, and Pedagogy. Pittsburgh: U of Pittsburgh Press,1997. Print.

Corbett, Edward P. J. Classical Rhetoric for the Modern Student. New York: Oxford University Press, 1990. Print.

Costa, Arthur L, and Bena Kallick. Learning and Leading with Habits of Mind: 16 Essential Characteristics for Success. Moorabbin, Vic: Hawker Brownlow Education, 2009. Print.

Costa, Arthur L, and Bena Kallick. Dispositions: Changing Mindsets for Learning. Thousand Oaks, CA: Corwin, 2013. Print.

Crystal, David. Txtng: The Gr8 Db8. Oxford: Oxford University Press, 2008. Print.

----"Texting." English Language Teachers Journal 62.1 (2008). Print.

Council of Writing Program Administrators. WPA Outcome Statements for First-Year 
Composition, April 2000; Amended July 2008. WPA. Web. 31 March 2013.

----CWPA Position on Pre-College Credit for Writing. WPA, September 2013. Web. 5

November 2013.

Council of Writing Program Administrators, National Council of Teachers of English, and National Writing Project. Framework for Success in Postsecondary Writing. July 2011. Web. April 2013.

DiYanni, Robert, ed. One Hundred Great Essays. New York: Pearson Longman, 2011. Print.

Del, Principe Anne, and Janine Graziano-King. "When Timing Isn't Everything: Resisting the Use of Timed Tests to Assess Writing Ability." Teaching English in the Two-Year College 35.3 (2008): 297-311. Print.

Devitt, Amy J. "Genre." A Guide to Composition Pedagogies. Eds. Gary Tate, Amy Rupiper Taggart, Kurt Schick and H. Brooke Hessler. New York: Oxford University Press, 2014. 146-162. Print.

Diamond, Laura. "Instant Messaging Shortcuts Creep into Homework." The Florida Union Times [Jacksonville, FL] 23 April 2013. Web. 26 Jan. 2015.

Dixon-Krauss, Lisbeth. "Using Literature as a Context for Teaching Vocabulary." Journal of Adolescent and Adult Literacy 45 (2002): 310-318. Print.

DiYanni, Robert. Literature: Reading Fiction, Poetry, and Drama. Boston: McGraw Hill, 2007. Print.

Donahue, Christine. “Transfer, Portability, Generalization: (How) Does Composition 
Expertise“Carry’?” Exploring Composition Studies: Sites, Issues, perspectives. Eds. Kelly Ritter and Paul Kei Matsuda. Logan: Utah State University Press, 2012. 145-166. Print.

Dunn, Katherine. Geek Love. New York: Knopf, 1989. Print.

Faigley, Lester. Picturing Texts. New York: W.W. Norton, 2004. Print.

Fenwick, Tara J, and Richard Edwards. Actor-Network Theory in Education. Milton Park, Abingdon, Oxon: Routledge, 2010. Print.

Fenwick, Tara J, and Richard Edwards, eds. Researching Education Through Actor Network Theory. Malden, MA: John Wiley \& Sons, 2012. Print.

First-Year Writing: What Good Does It Do? Nov. 2013. Web. 25 November 2013.

Fitzgerald, F S. The Great Gatsby. New York: Scribner Paperback Fiction, 1995. Print.

Fleitz, Elizabeth. "Profits Over Process: AP English and the Decline of Writing Instruction." CEA Forum 36.1 (2007). Web. 3 Feb. 2013.

Fleming, David. "Rhetoric and Argumentation." A Guide to Composition Pedagogies. Eds. Gary Tate, Amy Rupiper Taggart, Kurt Schick and H. Brooke Hessler. New York: Oxford University Press, 2014. 248-265. Print.

Foster, David. "The Theory of AP English: A Critique." Advanced Placement English: Theory Politics, and Pedagogy. Eds. Gary Olson, Elizabeth Metzger, and Evelyn Ashton-Jones. Portsmouth: Boyton/Cook, 1989. 3-24. Print

Foundation for Critical Thinking. Institutions Using the Framework for Critical Thinking Developed by the Foundation for Critical Thinking, Mar. 2013 Web. 18 Sept. 2014.

Foust, Regan Clark, Holly Hertberg-Davis, and Carolyn M. Callahan. "Students' 
Perceptions of the Non-Academic Advantages and Disadvantages of Participation in Advanced Placement Courses and International Baccalaureate Programs." Adolescence 44.174 (2009): 289-312. Print.

Gladwell, Malcolm. Outliers: The Story of Success. New York: Little Brown and Company, 2008. Print.

Goldblatt, Eli. Because We Live Here: Sponsoring Literacy Beyond the College Curriculum. Cresskill, NJ: Hampton Press, 2007. Print.

Graff, Gerald, and Cathy Birkenstein. "They Say / I Say": The Moves That Matter in Academic Writing, New York: W.W. Norton, 2014. Print.

Green, J., and D. Bloome. "Ethnography and Ethnographers of and in Education: A Situated Perspective." Handbook of Research on Teaching Literacy through the Communicative and Visual Arts. Eds. J. Flood, S. B. Heath and D. Lapp. New York: Macmillan, 1997. 181-202. Print.

Grettano, Teresa, Rebecca Ingalls, and Tracy Ann Morse. "The Perilous Vision of the Outcomes Statement." The WPA Outcomes Statement a Decade Later. Eds. Behm, Glau, Holdstein, Roen, \& White. Anderson, S.C: Parlor Press, 2013.45-57. Print.

Hansen, Kristine. "The Framework for Success in Postsecondary Writing: Better than the Competition, Still Not All We Need." College English 74.6 (2012): 540-543. Print.

Hansen, Kristine, Suzanne Reeve, Jennifer Gonzalez, Richard R. Sudweeks, Gary L. Hatch, Patricia Esplin and William S. Bradshaw. "Are Advanced Placement English and First-Year College Composition Equivalent? A Comparison of 
Outcomes in the Writing of Three Groups of Sophomore College Students." Research in the Teaching of English 40.4 (2006): 461-501. Print.

----“An Argument for Changing Institutional Policy on Granting AP Credit in English: An Empirical Study of College Sophomores’ Writing.” Writing Program Administration 28.1-2 (2004): 24-54. Web. 15 Apr. 2013.

Hansen, Kristine, and Christine R. Farris. College Credit for Writing in High School: The 'Taking' Care of Business. Urbana, IL: National Council of Teachers of English, 2010. Print.

Harrington, Susanmarie, Keith Rhodes, Ruth Overman Fischer and Rita Malenczyk, eds. The Outcomes Book: Debate and Consensus After the WPA Outcomes Statement. Logan: Utah State University Press, 2005. Print.

Harrington, Susanmarie. "Introduction: Celebrating and Complicating the Outcomes Statement." The Outcomes Book: Debate and Consensus After the WPA Outcomes Statement. Eds. Susanmarie Harrington, Keith Rhodes, Ruth Overman Fisher, and Rita Malenczyk Logan: Utah State University Press, 2005. xv-xix. Print.

Harris, Joseph, John D. Miles, and Charles Paine, eds. Teaching with Student Texts: Essays Toward an Informed Practice. Logan: Utah State University Press, 2010. Print.

Hartman, Pamela. “'Loud on the Inside': Working-Class Girls, Gender, and Literacy.” RTE 41.1 (2006): 82-117. Print.

Heath, Shirley Brice. Ways With Words. New York: Cambridge, 1983. Print.

Heath, Shirley Brice, and Brian V. Street. On Ethnography. New York: Teachers College 
Press, 2008. Print.

Henning, Martha L. "Ethos, Pathos, and Logos." Friendly Persuasion: Classical Rhetoric--Now! Durhamtech, Aug. 1998. Web. 5 Feb. 2015.

Henry. Personal Interview. 10 Mar. 2014.

Hesse, Douglas. "Afterward: of Cellists and Writers, Getting Better and Getting On.” College Credit for Writing in High School: The 'Taking Care of' Business. Eds. Kristine Hansen and Christine R. Farris. Urbana, IL: National Council of Teachers of English, 2010. 283-292. Print.

Hillocks, George. Research on Written Composition: New Directions for Teaching. New York: National Conference on Research in English, 1986. Print.

---- "'EJ" in Focus: Teaching Argument for Critical Thinking and Writing: An Introduction." The English Journal 99.6 (2010): 24-32. Print.

Holladay, Sylvia. A. "AP and the Problems of Testing." AP English: Theory, Politics, and Pedagogy. Eds. Gary A. Olson, Elizabeth Metzger, and Evelyn Ashton-Jones, Portsmouth, NH: Boynton/Cook. 65-82. Print.

Howard, Rebecca Moore, and Sandra Jamieson. "Researched Writing." A Guide to Composition Pedagogies. Eds. Gary Tate, Amy Rupiper Taggart, Kurt Schick and H. Brooke Hessler. New York: Oxford University Press, 2014.231-247. Print. Howard, Rebecca M. "Plagiarisms, Authorships, and the Academic Death Penalty." College English. 57.7 (1995): 788-806. Print.

Hull, Glynda, Mike Rose, Kay Losey Fraser, and Marisa Castellano. "Remediation as Social Construct: Perspectives from an Analysis of Classroom Discourse." CCC. 42.3 (1991): 299-329. Print. 
Huot, Brian. "Toward a New Theory of Writing Assessment." CCC 47.4 (1996): 549-66. Print.

Jefferson County Public Schools. High School Data Book. 8 August 2013. Web. 24 November 2013.

---- Data Book-2013 Advanced Placement Results. 8 Aug. 2013. Web. 24 Nov. 2013.

Jolliffe, David A., and Bernard Phelan. “Advanced Placement, Not Advanced Exemption: Challenges for High Schools, Colleges, and Universities.” Delivering College Composition: The Fifth Canon. Ed. Kathleen Blake Yancey. Portsmouth: Boynton/Cook, 2006. 89-103. Print.

Jolliffe, David A. "Who Is Teaching Composition Students to Read and How Are They Doing It?" Composition Studies 31.1 (2003): 127-42. Print.

Jones, Joseph. "The Beginnings of AP and the Ends of First-Year College Writing." College Credit for Writing in High School: The 'Taking' Care of Business. Eds.

Kristine Hansen and Christine R. Farris. Urbana, IL: National Council of Teachers of English, 2010. 43-67. Print.

----“Recomposing the AP English Exam.” English Journal 91 (2001): 51-56. Print. Kafka, Franz, and A L. Lloyd. Metamorphosis. New York: Vanguard Press, 1946. Print. Keller, Dan. "Feature a Framework for Rereading in First-Year Composition." Teaching English in the Two-Year College 41.1 (2013): 44-55. Print.

Kennedy, X J, Dorothy M. Kennedy, and Jane E. Aaron, eds. The Bedford Reader. Boston: Bedford/St. Martins, 2012. Print.

Kentucky Department of Education and Kentucky Council on Postsecondary Education. 
Unified Strategy for College and Career Readiness Senate Bill 1 (2009). KDE, 16 Aug 2010. Web. 2 Oct. 2014.

Kentucky Department of Education. College and Career Readiness Measures. KDE, 26 Oct. 2012. Web. 2 Oct. 2014.

----College Readiness Indicators. KDE, n.d. Web. 2 Oct. 2014.

----A Parent's Guide to School Accountability in Kentucky. KDE, Aug. 2012 Web. 12

Oct. 2014.

----Kentucky School District Report Card: Jefferson County. KDE, 11 Aug. 2014 Web.

12 Oct. 2014.

---Kentucky School Report Card: Blue Meadows High School. KDE, 27 Sept. 2014 Web. 12 Oct. 2014.

---Kentucky School Report Card: Green Gables High School. KDE, 27 Sept. 2014 Web. 12 Oct. 2014.

---Kentucky School Report Card: Orange Tree High School. KDE, 27 Sept. 2014 Web. 12 Oct. 2014.

---Kentucky School Report Card: Red River High School. KDE, 27 Sept. 2014 Web. 12 Oct. 2014.

---Kentucky School Report Card: Violet Fields High School. KDE, 27 Sept. 2014 Web. 12 Oct. 2014.

"Kentucky Educational Excellence Scholarship." KHEAA-Administered Programs. Kentucky Higher Education Assistance Authority, n.d. Web. 9 Nov. 2014. Kinneavy, James L, and John E. Warriner. Elements of Writing. Austin, TX: Holt, Rinehart and Winston, 1998. Print. 
Kinsella, Kate. Prentice Hall Literature. Upper Saddle River, N.J: Pearson Prentice Hall, 2007. Print.

Koos, Leonard V. "The Record of a Notable General-Education Program." The School Review 52.6 (1944): 376-377. Print.

Lau, Arthur. "Timed Writing Assessment as a Measure of Writing Ability: A qualitative Study.” Discussions 9.2 (2013): n. pag. Web. 12 Jan. 2015.

Loewen, James W. Lies My Teacher Told Me: Everything Your American History Textbook Got Wrong. New York: New Press, 1995. Print.

Lunsford, Andrea A., John J. Ruszkiewicz, and Keith Walters. Everything's an Argument: With Readings. Boston: Bedford/St. Martins, 2010. Print.

Lunsford, Andrea A., and Karen J. Lunsford. "'Mistakes Are a Fact of Life": A National Comparative Study." CCC 59.4 (2008): 781-806. Print.

Lunsford, Andrea A., Paul K. Matsuda, and Christine M. Tardy. The Everyday Writer. Boston: Bedford/St. Martin's, 2013. Print.

Mahala, Daniel, and Michael J. Vivion. "The Role of AP and the Composition Program." Writing Program Administration 17.1-2 (1993): 43-57. Web. 15 Apr. 2013. Maimon, Elaine P., Janice Peritz, and Kathleen B. Yancey. A Writer's Resource: A Handbook for Writing and Research. New York: McGraw-Hill, 2010. Print. McComiskey, Bruce. "Bridging the Divide: The (Puzzling) Framework and the Transition from K-12 to College Writing Instruction.” College English 74.6 (2012): 537-540. Print.

McKillip, Mary E. M., and Anita Rawls. "A Closer Examination Of The Academic Benefits Of AP." Journal of Educational Research 106.4 (2013): 305-318. Print. 
Miller, Robert K. The Informed Argument. Boston: Thomson/Wadsworth, 2007. Print. Modu, Christopher C., and Eric Wimmers. "The Validity of the Advanced Placement English Language and Composition Examination.” College English 43 (1981): 609-620. Print.

Newkirk, Thomas. "Seduction and Betrayal in Qualitative Research.” Ethics and Representation in Qualitative Studies of Literacy. Eds. Peter Mortensen and Gesa E. Kirsch. Urbana, IL: NCTE, 1996. 3-16. Print.

Nickoson, Lee, and Mary P. Sheridan, eds. Writing Studies Research in Practice: Methods and Methodologies. Carbondale: Southern Illinois University Press, 2012. Print.

Noguchi, Rei R. Grammar and the Teaching of Writing: Limits and Possibilities. Urbana, IL: National Council of Teachers of English, 1991. Print.

O'Brien, Tim. The Things They Carried: A Work of Fiction. Boston: Houghton Mifflin, 1990. Print.

---- "The Vietnam in Me." New York Times Magazine. (1994). Print.

Olson, Gary A., Elizabeth Metzger, and Evelyn Ashton-Jones, eds. Advanced Placement English: Theory, Politics, and Pedagogy. Portsmouth: Boyton/Cook, 1989. Print. O’Neill, Peggy, Linda Adler-Kassner, Cathy Fleischer, and Anne-Marie Hall. 'Creating the Framework for Success in Postsecondary Writing." College English 74.6 (2012): 520-524. Print.

Orwell, George. 1984: A Novel. New York: New American Library, 1950. Print.

Owen. Personal Interview. 13 Mar. 2014.

---- Personal Interview. 24 Mar. 2014. 
---- Personal Interview. 9 Apr. 2014.

---- Personal Interview. 29 Oct. 2014.

---- Personal Interview. 5 Dec. 2014.

Pahl, Larry. “Another Look At AP.” Social Education 78.1 (2014): 38-44. Print.

Paul, Richard, and Linda Elder. The Miniature Guide to Critical Thinking: Concepts and

Tools. Dillon Beach, CA: Foundation for Critical Thinking, 2009. Print.

"Paul-Elder Critical Thinking Framework." University of Louisville Ideas To Action.

University of Louisville, n.d. Web. 12 Oct. 2014.

Perkins, David. Forward. Learning and Leading with Habits of Mind. Edited By Arthur

L. Costa and Bena Kallick. 2008. Moorabbin, Vic: Hawker Brownlow Education, 2008. xi-xv. Print.

Peterson, Linda H, and John C. Brereton, eds. The Norton Reader: An Anthology of Nonfiction. New York: W.W. Norton, 2004. Print.

Phillips, Donna C. K, Chandra J. Foote, and Laurie J. Harper. "Strategies for Effective Vocabulary Instruction." Reading Improvement. 45.2 (2008). Print.

Phillips, Harry L, and Patricia Bostian. The Purposeful Argument: A Practical Guide. Boston: Wadsworth, 2012. Print.

Price, Margaret. "Beyond 'Gotcha!': Situating Plagiarism in Policy and Pedagogy.” CCC 54.1 (2002): 88-115. Print.

Puhr, Kathleen M. "The Evolution of AP English Language and Composition." College Credit for Writing in High School: The 'Taking' Care of Business. Eds. Kristine Hansen and Christine R. Farris. Urbana, IL: National Council of Teachers of English, 2010. 68-85. Print. 
Puhr, Kathleen M., with sections by David Jolliffe. AP English Language and Composition Teacher's Guide. College Board Inc., 2007. Web. 14 July 2013.

Ramage, John D., John C. Bean and June Johnson. Writing Arguments: A Rhetoric with Readings. 8th Ed., 2010. Print.

Remediation: Higher Education's Bridge to Nowhere. Complete College America, 2012. Print.

Rhodes, Keith, Irvin Peckham, Linda S. Bergmann, and William Condon. "The Outcomes Project: The Insiders' History.” The Outcomes Book: Debate and Consensus After the WPA Outcomes Statement. Eds. Susanmarie Harrington, Keith Rhodes, Ruth Overman Fischer, and Rita Malenczyk. Logan: Utah State University Press, 2005. Print. 8-17.

Roskelly, Hephzibah, and David A. Jolliffe. Everyday Use: Rhetoric at Work in Reading and Writing. New York: Pearson/Longman, 2005. Print.

Ruszkiewicz, John J. A Reader's Guide to College Writing. Boston: Bedford/St. Martin's, 2014. Print.

Salvatori, Mariolina Rizzi, and Patricia Donahue. "Stories about Reading: Appearance, Disappearance, Morphing, and Revival.” College English 75 (2012): 19-217. Print.

Schwartz, Jeffrey. "Reflections of an AP Reader." English Journal 93.4 (2004): 53-7. Print.

Scott, Tim, Homer Tolson, and Yi-Hsuan Lee. "Assessment Of Advanced Placement Participation And University Academic Success In The First Semester: Controlling For Selected High School Academic Abilities." Journal Of College 
Admission 208 (2010): 26-30. Education Full Text (H.W. Wilson). Web. 10 Nov. 2014.

Sebranek, Patrick, Verne Meyer, and Dave Kemper. Write for College: A Student Handbook. Wilmington, Mass: Write Source, Great Source Education Group, 2007. Print.

Severino, Carol. "The Problems of Articulation: Uncovering More of the Composition Curriculum.” College English 74.6 (2012): 533-536. Print.

Shaw, Donita Massengill, Carolyn Carlson, and Mickey Waxman. “An Exploratory Investigation into the Relationship Between Text Messaging and Spelling." The NERA Journal 43.1 (2007): 57-62. Print.

Shea, Renée H., Lawrence Scanlon, and Robin D. Aufses. The Language of Composition: Reading, Writing, Rhetoric. Boston: Bedford / St. Martins, 2008. Print.

----The Language of Composition: Reading, Writing, Rhetoric. $2^{\text {nd }}$ edition, Boston: Bedford/ St. Martins, 2013. Print.

Sommers, Jeff. "Illustrating the Reading Process: The In-Class Read-Aloud Protocol." Teaching English in the Two-Year College 23 (2005): 298-306. Print.

Sophia. Personal Interview. 11 Mar. 2014.

Southern Regional Education Board and National Center for Public Policy and Higher Education. "Beyond The Rhetoric: Improving College Readiness Through Coherent State Policy. A Special Report By The National Center For Public Policy And Higher Education And The Southern Regional Education Board." Southern Regional Education Board (SREB) (2010): ERIC. Web. 4 Feb. 2015 Spear, Karen, and Gretchen Flesher. "Continuities in Cognitive Development: AP 
Students and College Writing." Advanced Placement English: Theory, Politics, and Pedagogy. Eds. Gary Olson, Elizabeth Metzger, and Evelyn Ashton-Jones. Portsmouth: Boyton/Cook, 1989. 25-51. Print.

Street, Brian. Literacy in Theory and Practice. Cambridge: Cambridge University Press, 1984. Print.

Stella. Personal Interview. 13 Mar. 2014.

Sullivan, Patricia. "Ethnography and the Problem of the 'Other'." Methods and Methodology in Composition Research. Ed. Gesa Kirsch and Patricia M. Sullivan. Carbondale: Southern Illinois University Press, (1992): 97-114. Print.

Sullivan, Patrick. "Essential Habits of Mind for College Readiness." College English 74.6 (2012): 547-551. Print.

Summerfield, Judith, and Phillip M. Anderson. "A Framework Adrift.” College English 74.6 (2012): 544-547. Print.

Tate, Gary, Amy Rupiper Taggart, Kurt Schick, H. Brooke Hessler, eds. A Guide to Composition Pedagogies, $2^{\text {nd }}$ edition. New York: Oxford University Press, 2014. Print.

"Texting, Testing Destroys Kids' Writing Style." USA Today Magazine. 2008. Web. 25 Jan. 2015 .

Thoreau, Henry D. Civil Disobedience. New York: Classic Books America, 2009. Print. Tolman, Deborah L., and Mary Brydon-Miller. "Interpretive and Participatory Research Methods." From Subjects to Subjectivities: A Handbook of Interpretive and Participatory Methods. Eds. Deborah L. Tolman and Mary Brydon-Miller. New York: New York University Press, 2001. 3-11. Print. 
University of Louisville Composition Program. Composition Program Outcomes. Nov. 2006 University of Louisville. Web. 15 May 2013.

----Policy Against Plagiarism Detection Software. University of Louisville. Mar. 2009. Web. 22 Nov. 2014.

Valentine, Katherine. "Plagiarism as Literacy Practice: Recognizing and Rethinking Ethical Binaries." CCC 58.1 (2006): 89-109. Print.

Vonnegut, Kurt. Slaughterhouse-Five, Or, the Children's Crusade: A Duty-Dance with Death. New York: Dell, 1988. Print.

Warren, James. "First-Year College Writing and the AP English Language Exam: How a High School/College Partnership Affected Exam Performance." Writing Program Administrators 33.3 (2010): 78-104. Web. 3 Feb. 2013.

Weir, Peter, Steven Haft, Paul J. Witt, Tony Thomas, Tom Schulman, Robin Williams, Robert S. Leonard, Ethan Hawke, Josh Charles, Gale Hansen, Dylan Kussman, and Maurice Jarre. Dead Poets Society. Burbank, Calif: Touchstone Home Video, 1998

White, Edward M. "Testing in and Testing out." Writing Program Administration 32.1-2 (2008):129-142. Web. 15 Apr. 2013.

---- "The Origins of the Outcomes Statement." The Outcomes Book: Debate and Consensus After the WPA Outcomes Statement. Eds. Susanmarie Harrington, Keith Rhodes, Ruth Overman Fischer, and Rita Malenczyk. Logan: Utah State University Press, 2005. 3-7. Print.

Whitley, Colleen, and Deirdre Paulsen. "What Do the Students Think? An Assessment of 
AP English Preparation for College Writing." College Credit for Writing in High School: The 'Taking' Care of Business. Eds. Kristine Hansen and Christine R. Farris. Urbana, IL: National Council of Teachers of English, 2010. 86-118. Print. Williams, Bronwyn T. Tuned In: Television and the Teaching of Writing. Portsmouth, NH: Boynton/Cook, 2002. Print.

Williams, Cheri L. "Dealing with the Data: Ethical Issues in Case Study Research." Ethics and Representation in Qualitative Studies of Literacy. Eds. Peter Mortensen and Gesa E. Kirsch. Urbana: NCTE. 1996. 40-57. Print. Williams, James D. “Grammar and Usage.” Concepts in Composition. Ed. Irene Clark. Mahawah, NJ: Lawrence Erlbaum Associates. 2003. 313-337. Print.

Willingham, Donna, and Debra Price. "Theory to practice: Vocabulary Instruction in Community College Developmental Education Reading Classes: What the Research Tells Us.” Journal of College Reading and Learning 40 (2009): 91-105. Print.

Woolf, Virginia. Mrs. Dalloway. San Diego: Harcourt Brace Jovanovich, 1990. Print. Wright, Richard. Native Son. New York: Perennial, 2003. Print.

Yancey, Kathleen Blake. "Standards, Outcomes and All That Jazz." The Outcomes Book: Debate and Consensus After the WPA Outcomes Statement. Eds. Susanmarie Harrington, Keith Rhodes, Ruth Overman Fischer, and Rita Malenczyk. Logan: Utah State University Press, 2005. 18-23. Print. 
APPENDICES 


\section{Appendix A:}

1. Chart of Participating School Data 2013-2014

2. Teacher Interview Script

3. Student Interview Script

4. Student Survey

5. Student Survey Results 


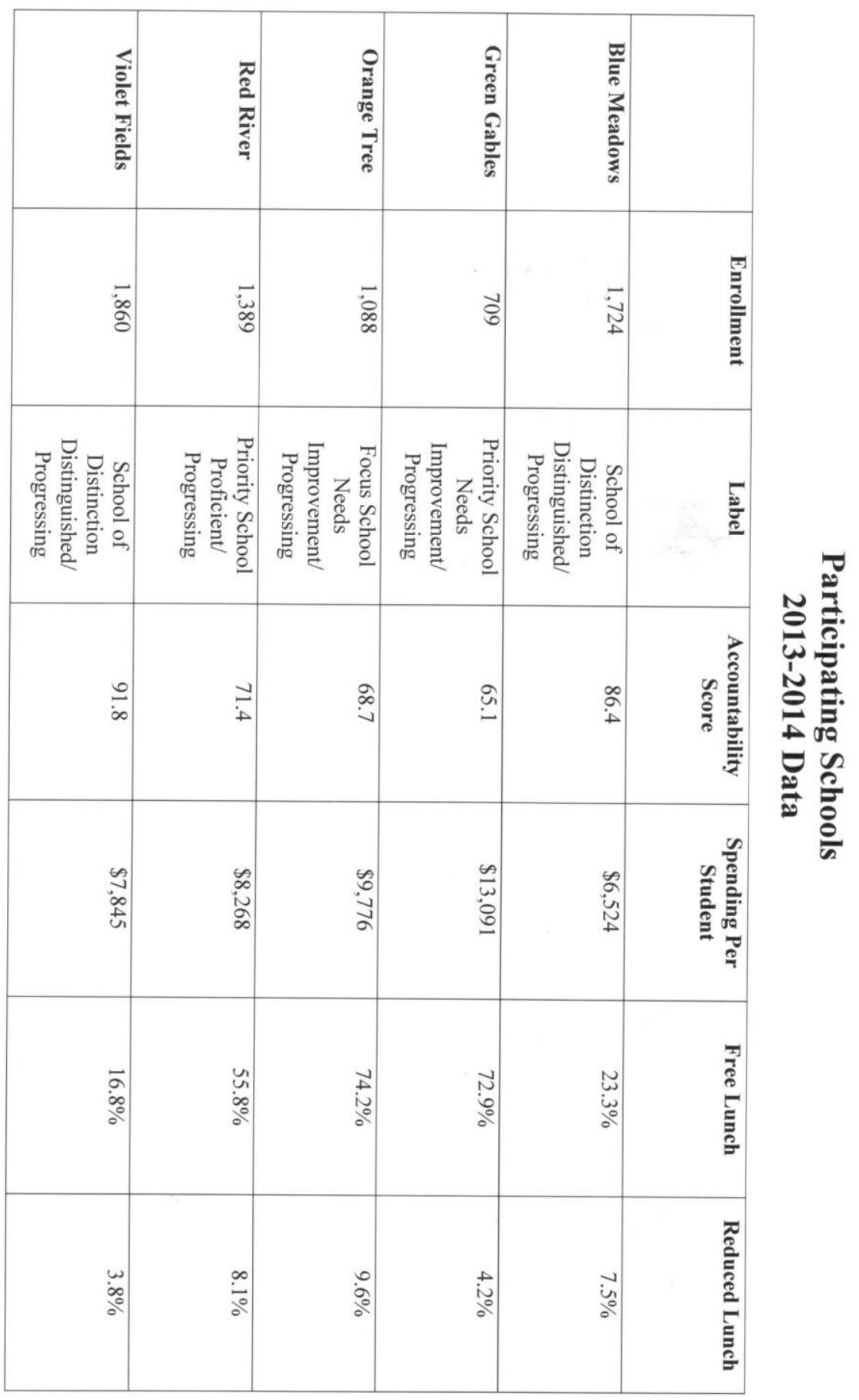




\section{Interview Script for Teachers \\ Project Title: Exploring AP English Language as a Site of First-Year Composition IRB Approval \#: 13.0942}

1. How long have you been teaching AP English Language and Composition?

2. Can you describe the type of training that you have had related to teaching AP English Language and Composition? When did this training take place?

3. What do you see as the purpose of AP English Language and Composition?

4. What types of assignments do you include in your AP English Language and Composition course?

5. What types of writing pedagogies or instructional strategies do you frequently employ in teaching AP English Language and Composition?

6. Can you talk about how you approach the writing process in your AP English Language and Composition course?

7. Can you talk about how you see AP English Language and Composition relating to first-year college writing?

8. Can you talk about how you see AP English Language and Composition preparing students for the types of writing they will be asked to complete in college?

9. What do you think are the benefits for a student taking AP English Language and Composition? What are the drawbacks?

10. Describe any local or national collaborative efforts that you know about between AP English and firstyear college writing programs. 
Interview Script for Students

Project Title: Exploring AP English Language and Composition as a Site of First-Year Composition IRB Approval \#: 13.0942

1. Why did you want to take the AP English Language and Composition course?

2. What have you learned from taking the AP English Language and Composition course?

3. What do you see as the purpose of the AP English Language and Composition course?

4. In what ways, if any, do you see the AP English Language and Composition course:

a. relating to first-year college writing?

b. preparing you for the writing you will do in college?

c. impacting your transition to college? 
Exploring AP English Language and Composition as a Site of First-Year Writing Student: Survey on Students Attitudes/Beliefs Concerning AP English Language and Composition and First-Year Writing

IRB Assigned Number: 13.0942

\begin{tabular}{|c|c|c|c|c|c|}
\hline Statement & $\begin{array}{l}\text { Strongly } \\
\text { Agree }\end{array}$ & Agree & Neutral & Disagree & $\begin{array}{l}\text { Strongly } \\
\text { Disagree }\end{array}$ \\
\hline \multicolumn{6}{|c|}{$\begin{array}{l}\text { The following statements ask you to reflect on your enrollment in AP English Language and } \\
\text { Composition and attitudes towards first-year college writing. Please indicate if your level of } \\
\text { agreement with each statement. }\end{array}$} \\
\hline $\begin{array}{l}\text { I plan on enrolling in some type of first-year } \\
\text { writing class during my first year at college. }\end{array}$ & $\begin{array}{l}\text { Strongly } \\
\text { Agree }\end{array}$ & Agree & Neutral & Disagree & $\begin{array}{l}\text { Strongly } \\
\text { Disagree }\end{array}$ \\
\hline $\begin{array}{l}\text { My AP English Language and Composition } \\
\text { course is preparing me for college level writing } \\
\text { tasks. }\end{array}$ & $\begin{array}{l}\text { Strongly } \\
\text { Agree }\end{array}$ & Agree & Neutral & Disagree & $\begin{array}{l}\text { Strongly } \\
\text { Disagree }\end{array}$ \\
\hline $\begin{array}{l}\text { I see connections between my AP English } \\
\text { Language and Composition course and first- } \\
\text { year college writing. }\end{array}$ & $\begin{array}{l}\text { Strongly } \\
\text { Agree }\end{array}$ & Agree & Neutral & Disagree & $\begin{array}{l}\text { Strongly } \\
\text { Disagree }\end{array}$ \\
\hline $\begin{array}{l}\text { The assignments for my AP English Language } \\
\text { and Composition course are comparable to } \\
\text { what I would expect in a first-year college } \\
\text { writing course. }\end{array}$ & $\begin{array}{l}\text { Strongly } \\
\text { Agree }\end{array}$ & Agree & Neutral & Disagree & $\begin{array}{l}\text { Strongly } \\
\text { Disagree }\end{array}$ \\
\hline $\begin{array}{l}\text { My AP English Language and Composition } \\
\text { course is preparing me to take the AP English } \\
\text { Language and Composition exam. }\end{array}$ & $\begin{array}{l}\text { Strongly } \\
\text { Agree }\end{array}$ & Agree & Neutral & Disagree & $\begin{array}{l}\text { Strongly } \\
\text { Disagree }\end{array}$ \\
\hline $\begin{array}{l}\text { My AP English Language and Composition } \\
\text { course is a rhetoric course. }\end{array}$ & $\begin{array}{l}\text { Strongly } \\
\text { Agree }\end{array}$ & Agree & Neutral & Disagree & $\begin{array}{l}\text { Strongly } \\
\text { Disagree }\end{array}$ \\
\hline
\end{tabular}


Figure 1: Survey Question \#1

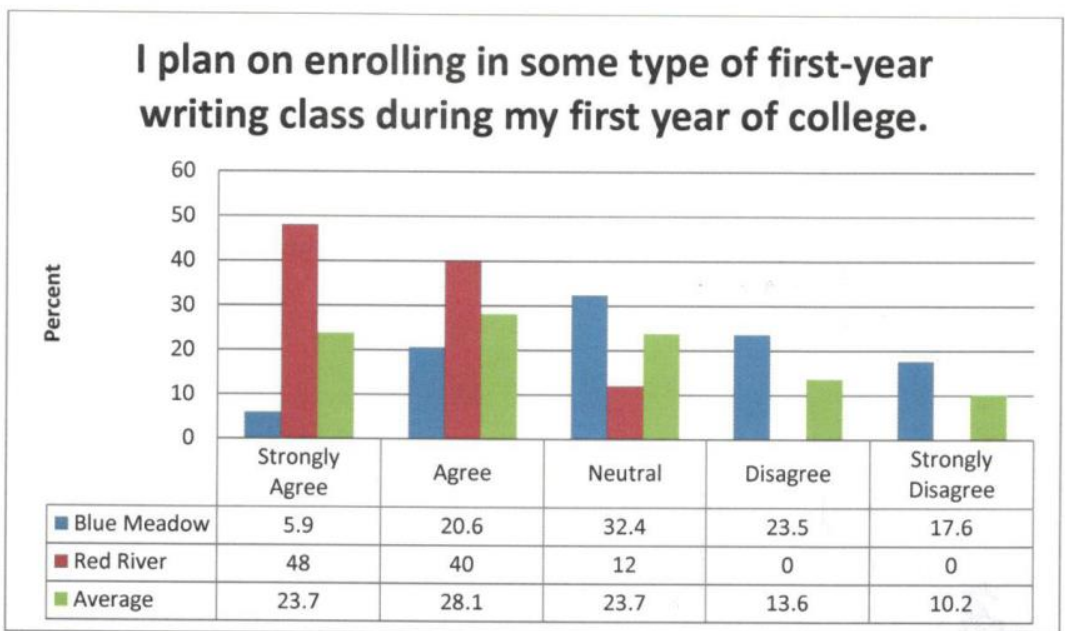

Figure 2: Survey Question \#2

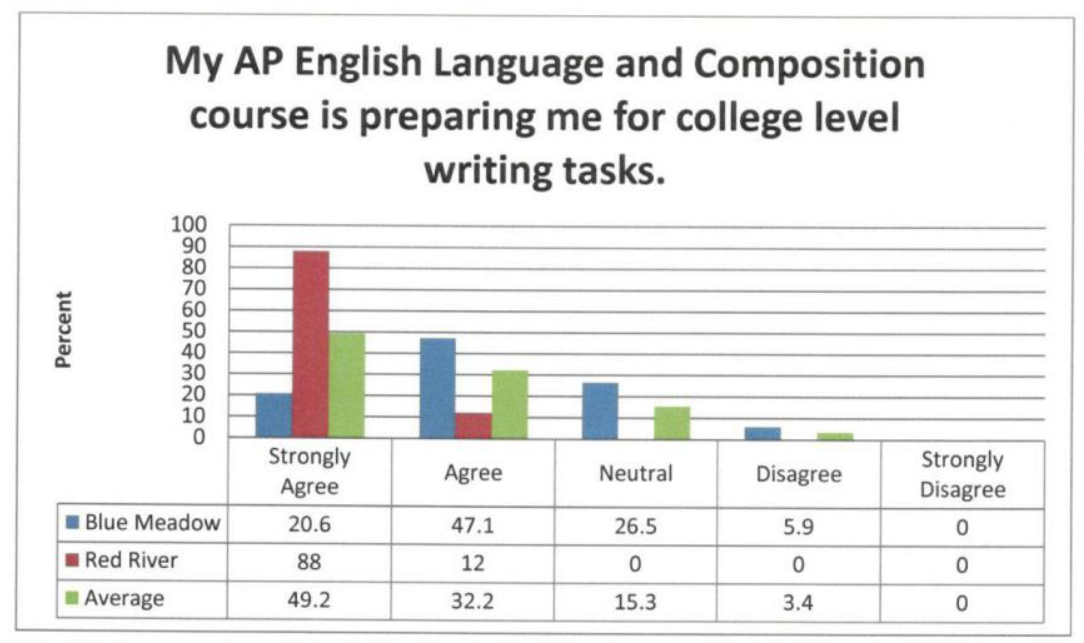


Figure 3: Survey Question \#3

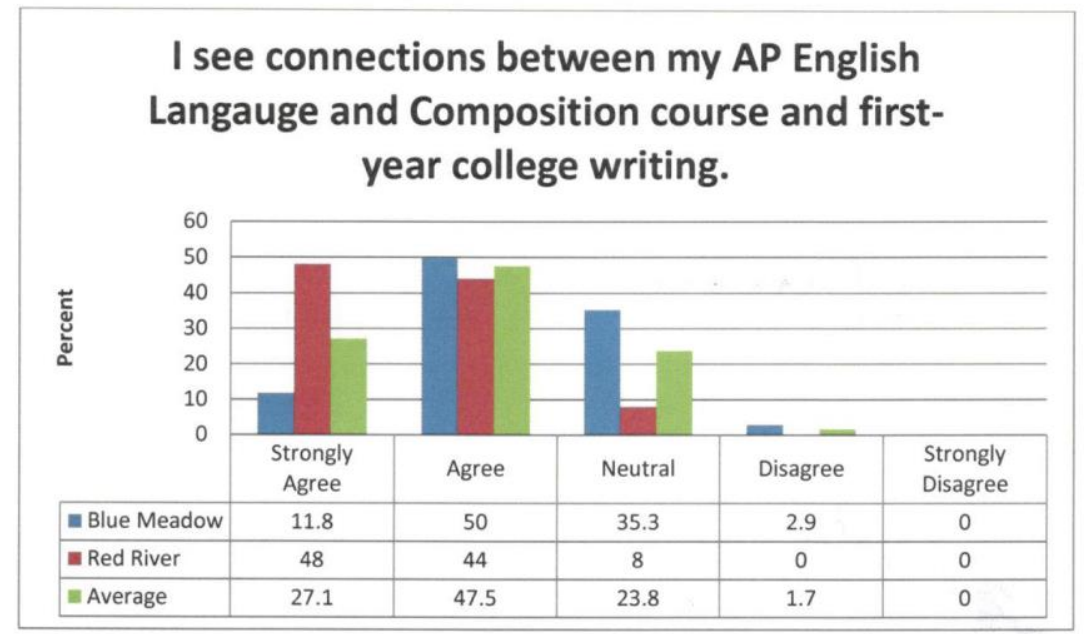

Figure 4: Survey Question 4

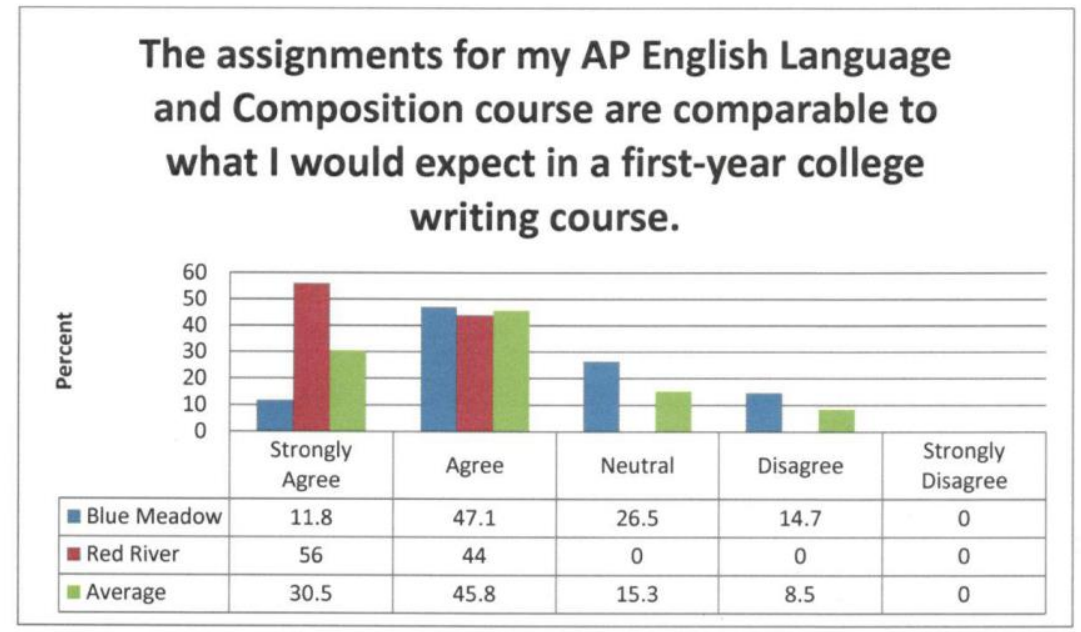


Figure 5: Survey Question \#5

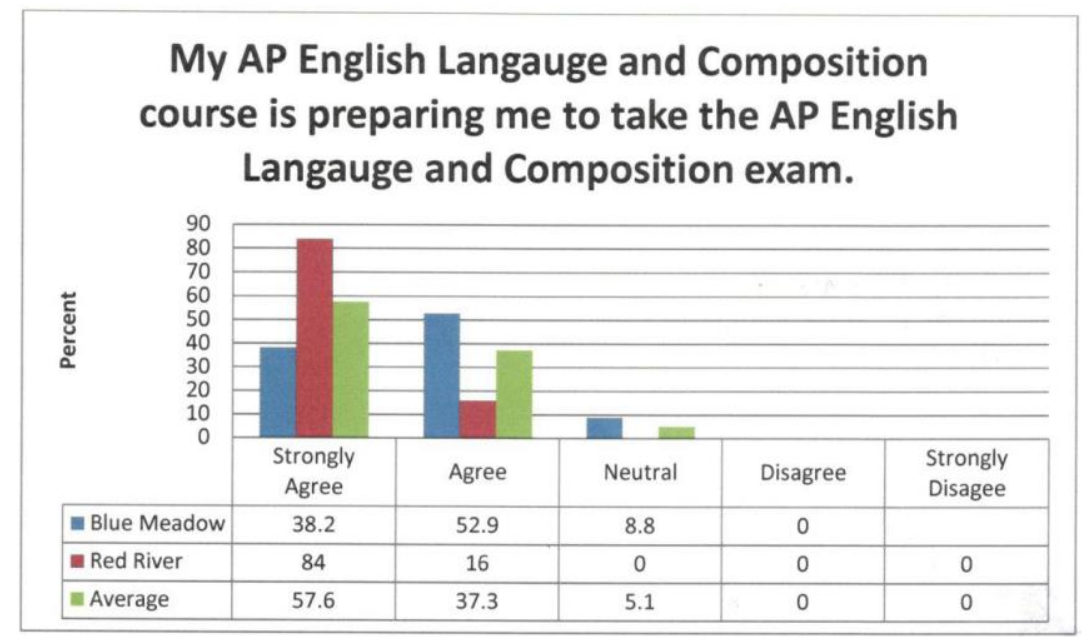

Figure 6: Survey Question \#6

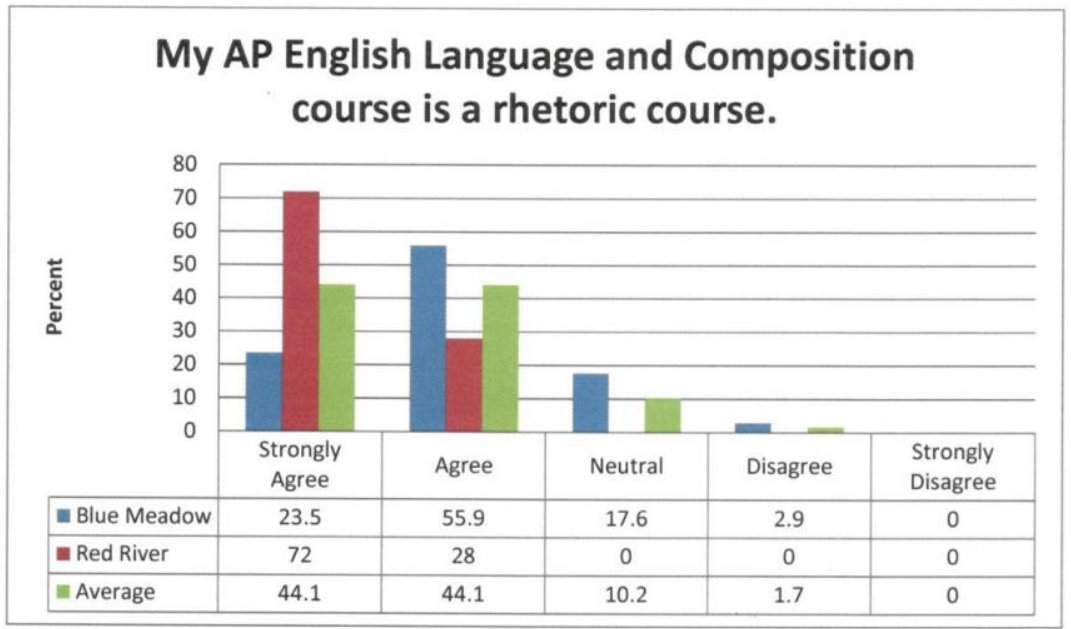




\section{Appendix B:}

1. Course Syllabus - Green Gables High School

2. Course Syllabus - Orange Tree High School

3. Course Syllabus-Red River High School

4. Course Syllabus-Violet Fields High School 


\title{
AP Language and Composition 2013-14
}

\author{
3
}

Welcome to AP Language and Composition for juniors! This course is an English course, a college-prep course, and a preparatory course for the College Board's Advanced Placement Exam in English Language and Composition. If you are enrolled in this course, you are required to take the AP Exam.

The literature component will build on analytical skills you have been developing throughout high school. The language and writing component of the course trains you to analyze prose style and rhetoric; and to write effective analytical, persuasive, and document-based essays, which can be used for your final Senior Writing Portfolio.

Per the AP College Board Requirements, students in this course will:

1. Write in several forms (e.g., narrative, expository, analytical, and argumentative essays) about a variety of subjects (e.g., public policies, popular culture, personal experiences).

2. Write essays that proceed through several stages or drafts, with revision aided by teacher and peers.

3. Write in informal contexts (e.g., imitation exercises, journal keeping, collaborative writing, and in-class responses) designed to help them become increasingly aware of themselves as writers and of the techniques employed by the writers they read.

4. Complete expository, analytical, and argumentative writing assignments that are based on readings representing a wide variety of prose styles and genres.

5. Analyze a variety of fiction and nonfiction readings (e.g., short stories, novels, essays, journalism, political writing, science writing, nature writing, autobiographies/biographies, diaries, history, criticism) that are selected to give students opportunities to identify and explain an author's use of linguistic strategies and techniques.

6. Analyze how graphics and visual images both relate to written texts and serve as alternative forms of text themselves.

7. Understand and be able to utilize research skills, and in particular, the ability to evaluate, use, and cite primary and secondary sources. The course assigns projects such as the researched argument paper, which goes beyond the parameters of a traditional research paper by asking students to present an argument of their own that includes the analysis and synthesis of ideas from an array of sources.

8. Cite sources using a recognized editorial style (e.g. MLA) 
As your AP instructor, I will provide instruction and feedback on your writing assignments, both before and after you revise your work, that will help you develop these skills:

- A wide-ranging vocabulary used appropriately and effectively

- A variety of sentence structures, including appropriate use of subordination and coordination

- Logical organization, enhanced by specific techniques to increase coherence, such as repetition, transitions, and emphasis

- A balance of generalization and specific, illustrative detail

- An effective use of rhetoric, including controlling tone, establishing and maintaining voice, and achieving appropriate emphasis through diction and sentence structure

\section{Required Texts:}

Students will read several novels on their own outside of class, which will be selfselected from a list of approved texts that focus on the current topic of instruction.

There will be specific assignments to accompany the reading of these texts. This list is subject to change, and students may make a case for any appropriate text to be added as well, providing it fits in with our course of study.

Beyond this, all materials will be provided and will include selections from:

1. 40 Model Essays, A Portable Anthology by Jane E. Aaron

2. The Bedford Reader, Bedford/St. Martin's

3. Walden \& Civil Disobedience by Henry David Thoreau

4. The Narrative of the Life of Frederick Douglass by Frederick Douglass

5. The Prentice Hall Reader, selected texts

6. Everything's an Argument

7. The Language of Composition, Bedford/St. Martin's

8. Selected speeches and persuasive essays (Alice Walker, Virginia Woolf, MLK, etc.)

9. Advertisements and political cartoons

10. Editorials from newspapers, magazines and online publications

\section{Exam Preparation:}

- Each quarter, we will pair released items from the AP Language and Composition Exam in past years that are related to our unit focus, practicing the annotation of passages given on the exam and the answering of multiple choice questions.

- This will also be quite useful for ACT and WOD testing preparation, as you will be inundated with testing this spring. 


\section{Vocabulary Study:}

- Focus is on all AP Language and Composition terms that relate to purpose, style, tone, and rhetorical devices.

- Begin building the bank of flashcards in the "vocabulary bucket"

- Work with www.quizlet.com for practice each week

\section{Writing:}

- In conjunction with the guidance of the JCPS District, we will pair our study of the rhetorical strategies authors use with the writing of various pieces demonstrating students' interest and learning, for inclusion in writing portfolios.

- We will spend time considering the guiding question of each unit, brainstorm ideas on how to turn this into an appropriate writing piece, and follow it through all of the stages of writing, until we are satisfied with a solid draft for the portfolio. These stages include:

- Pre-writing/brainstorming

- Drafting

- Conferencing with the instructor and peers

- Revising

- Constructive criticism

- Completion of a solid draft

- We will also be doing timed writings that mimic the experience of the AP Language and Composition exam, and the On-Demand Writing test that is administered in KY.

- We will look at prompts related to the focus of the unit and practice with the construction of an appropriate response by viewing sample responses, studying the scoring of them, and attempting to craft our own.

\section{Course Overview}

Trimester A: Course Introduction, Introduction to Rhetoric, Author Style Choices, Author Purpose, Identifying and Analyzing Arguments

\section{Skills:}

- Close Reading

- Annotation

- Explication

- Rhetorical Triangle

- Identifying Types of Arguments

- Identifying Rhetorical Devices

- Analyzing Arguments 


\section{Unit Questions:}

- How do writers establish a higher purpose in their writing?

- In what ways do they effectively achieve these higher purposes?

- Similarly, what is your purpose for doing things in everyday life? What drives you to write, to sing, to draw, to learn?

- Why do writers make arguments?

- How do writers make arguments?

- How do writers use fiction to make an argument?

Trimester B: Developing and Supporting an Argument; The Synthesis Essay

Skills:

- Understanding Appeals

- Deductive and Inductive Reasoning

- Supporting an Argument

- Developing an Argument

- Synthesizing Information

- Identifying and Understanding Fallacies

- MLA Citation

- Understanding and Avoiding Plagiarism

Unit Questions:

- How do writers appeal to their specific audience?

- How can you make an effective argument?

- What issues in your world are ones where you feel driven to make an argument?

- How do you find and use sources to make your argument?

- How do you avoid fallacious arguments?

Trimester C: Use of Satire in Argumentation, Use of Visual Text in Argumentation, Preparing for Exams, Reflection

Skills:

- Understanding Satire

- Analyzing Visual Text

- Self-analysis and Reflection

Unit Questions:

- How do writers use Satire to make an argument?

- How can Visual Texts be used to support or make an argument?

- Why is it important to reflect on your own writing?

- How do I prepare for the exams? 


\section{Expectations:}

1. Arrive to class on time and prepared

a. Bring any required books, paper, pencil, pen, highlighters

2. Access to the internet and a word processing program (Microsoft Word) is essential. Please let me know if you do not have access to these things at home.

3. Attendance is mandatory in order to maintain a good grade. Many assignments in class cannot be replicated and you may miss important work. Assignments that can be made up may be, according to the school policy. It is YOUR responsibility to check in with me for make-up work. After 1 week, you may not make up any missing assignments.

4. Major assignments will not be accepted after their designated due dates

5. If you need help, please see me. I am available most days after school, and will be happy to provide you with extra support as needed. I do ask that you check with me first, so I can be sure to be available for you.

6. You WILL be required to do reading and writing outside of class. This is essentially a college course, and will function as such. This requires you to be organized, keep track of due dates, and work independently.

7. Discussion will be a significant aspect of class. Be mature. Give others the respect you want when you speak. Participate fully, contributing your ideas and responding to the ideas of others.

\section{Student Evaluation Practices \& Grading Policy}

AP courses traditionally follow the college grading scale, and the district allows these courses to deviate from the district grade scale to accommodate that. Therefore, see the scale below for the grade ranges. In order to assign point values, students will be graded on a rubric developed for that particular assignment, which will be distributed with the assignment. All major writing assignments will be graded using the College Board 9 point rubric.

\begin{tabular}{|l|l|l|}
\hline $\begin{array}{l}\text { AP } \\
\text { Scale }\end{array}$ & AP Essay Scale \\
\hline A+ & $100-97$ & High 7, 8/9 \\
\hline A & $96-93$ & Mid/Low 7,6 \\
\hline A- & $92-90$ & $5 / 4$ \\
\hline B+ & $89-87$ & $3 / 2$ \\
\hline B & $86-83$ & 1 \\
\hline B- & $82-80$ & 0 \\
\hline C+ & $79-77$ & \\
\hline C & $76-73$ & \\
\hline C- & $72-70$ & \\
\hline D+ & $69-67$ & \\
\hline D & $66-63$ & \\
\hline D- & $62-60$ & \\
\hline F & $59-$ & \\
\hline
\end{tabular}


English .

\section{Syllabus - AP English Language and Composition}

Course Objective: To offer a broad writing experience to allow students to sharpen their analytical and rhetorical skills. The course will focus on the art and analysis of argument, and how to apply rhetorical skills in future careers. A major course objective is to prepare students for the AP Advanced Placement exam, which will be given in May. Students will practice both test procedure and subject matter. Note: This course is a requirement of ; Advanced Diploma standards, but it can be taken by any student who wishes to study and hone analytical skills.

Introduction: Everything is an argument of some sort. Almost every topic of conversation could lead to a debate: Where should we eat? How much should we spend on clothes? May I stay out after curfew? Although you might not realize it, whenever you are trying to convince someone of your "side" of an argument, you are using rhetorical skills. Such skills, in a more refined form, are used throughout the workplace. magnet programs offer the insight into careers which involve frequent rhetorical situations. Lawyers have to argue their client's innocence. Doctors find themselves having to convince patients to follow directives. Business people have to convince banks to lend them money. Any career in politics revolves around rhetoric, whether it is during a campaign or attempting to pass a law. Rhetoric is the art of argument, and it can be a powerful tool.

Organizing Principals: The course requires students to:

- examine the nature and history of the English essay

- read broadly among a variety of authors, rhetorical purposes, and eras

- engage in a significant study of writing as an art

- learn to employ the fundamentals of sound argumentation

\section{Requirements:}

Reading: You are required to read and respond to your reading (see informal writing below) on a daily basis for this class. We will be reading from a variety of British and American writers, and identify and analyze how those authors use rhetorical strategies and techniques. Unlike your other English classes, this course will be focused on non-fiction work, especially essays and speeches. Some fiction will be included, but we will focus on the rhetorical aspects of the work. Our core texts include anthologies of essay writing by authors from various historical periods:

- DiYanni, Robert, ed. 100 Great Essays. $4^{\text {th }}$ ed. Boston: Longman, 2011.

- Maimon, Elaine P., et al. A Writer's Resource, A Handbook for Writing and Research. $2^{\text {nd }}$ ed. New York: McGraw-Hill, 2007.

- Shea, Renne H., et al. The Language of Composition, Reading Writing Rhetoric. Boston: Beford/St Martin's, 2008.

In addition, we will read from several supplemental texts including The Great Gastby, Hind Swaraj, and The Narrative of the Life of Frederick Douglass. 


\section{English}

Formal Papers: You will write six formal papers (one for each grading period), in a variety of forms (e.g. expository, analytical or argumentative essays), during the course of the year. Each paper will be focused on a specific form (narrative, expository, analytical, and argumentative), but the subjects will be varied and based upon your choice. Some of these papers will mirror the essays one will find on the AP Advance Placement test. The schedule will go as follows:

- $1^{\text {st }}$ six weeks: Personal Essay

- $2^{\text {nd }}$ six weeks: Persuasive Speech

- $3^{\text {rd }}$ six weeks: Rhetorical Analysis

- $4^{\text {th }}$ six weeks: Compare/Contrast Essay

- $5^{\text {th }}$ six weeks: Synthesis Paper

- $6^{\text {th }}$ six weeks: Issue Based Research Paper

Each paper will proceed through multiple drafts. We will use teacher conferences and peer response groups where students will help each other brainstorm, revise, edit and polish their papers. The teacher will provide formative feedback by commenting on the individual drafts and giving mini-lessons that focus on areas of improvement for the individual and the whole class. All papers will follow MLA guidelines. We will be using A Writer's Resource to learn how to do in-text citations and document sources. All final drafts must be emailed to me so I can screen them for plagiarism.

Informal Writing: Informal writing will take place every class day. Much of this writing will be responses to on our daily reading. Reading journals will be used for reading responses, reaction to visual rhetoric, note taking, and dialectical journaling. We will also write summaries and/or editorials of current events. Journal writing will often be shared with the class. Other in class writing will include practice AP exam essays, small group activities, and impromptu exercises.

Class Work and Quizzes: Other daily work will include vocabulary development, exercises in sentence structures (imitations), class discussions and debates, and analysis of current events. Since rhetoric surrounds us every day, and AP students are expected to keep up with the event of the world, we will take a "news quiz" each week.

Research: Scholars and professionals continually seek out information and data sources that they can integrate into their own arguments. We will learn how to seek out reliable sources in an unreliable world. We will work with the school library, and students will be required to visit the public library four times during the year for homework. Your final paper for the year will be an issue-based research paper where you will select an important cultural, political, or social issue and formulate a thesis based upon research. You will synthesize ideas from at least seven primary and secondary sources in support of your thesis. Students will conference with the teacher starting with their working thesis through several drafts. 


\section{English}

\section{Course Schedule:}

1st Six Weeks - Introduction to Rhetoric

This unit will introduce the organization and techniques of argument beginning with Aristotle and continuing to modern rhetoric. In particular, we will focus on rhetorical terminology, use of appeals, sentence structures (coordination and subordination), use of tone and voice, and logical organization. Students will read a variety of essays from 100 Great Essays, and ultimately compose their own personal essay.

- Terminology

- The Rhetorical Triangle

- Tone and Appeals

- Personal Essay Examples

- Paper 1 - Personal Essay

2nd Six Weeks - Political Argument and Fallacy

During the political season, students will read a variety of political speeches, ranging from The "Gettysburg Address" to "Obama's Inauguration Address." An emphasis will be placed on logical argument and the dangers of logical fallacies. The unit will also include a section about visual rhetoric by studying artwork (Picasso's Guernica) and advertising. The final paper for this unit will be a persuasive speech where the student defends a position on a current event topic. The speech must contain research from at least two sources that supports the student's argument.

- Logic and logical fallacies

- Political Speeches

- Guernica and visual literacy

- Paper 2 - Persuasive Speech

3rd Six Weeks - Analysis of Argument

This unit will revolve around the American Abolitionist movement of the eighteenth and nineteenth centuries. In particular, we will analyze how Frederick Douglass makes his ethical appeals against slavery though his use of dialogue, oratory style, figures of speech, and details. [C9d] The students will be introduced to dialectical journals as a form of note-taking, and MLA guidelines will be taught. The final product will be a rhetorical analysis of Douglass's writings.

- Whole class reading - The Autobiography of Frederick Douglass

- Quote response essays

- Dialectical journaling

- MLA guidelines

- Paper 3 - Rhetorical Analysis of The Autobiography of Frederick Douglass

4th Six Weeks - Civil Disobedience Unit

In 1839, Henry David Thoreau published an essay entitled "Resistance to Civil Government." In it he argues that individual conscience should take precedence over an unjust law. This pamphlet, later to be called "Civil Disobedience," has been the foundation of world changing events, including the liberation of India and the American Civil Rights movement. We will 


\section{English}

read several papers, essays, and letters that show the development of nonviolent resistance and how these affected world history. A separate focus will look at how visual rhetoric is used in advertising by studying both print and multimedia sources.

- "Civil Disobedience," Thoreau

- Hind Swaraj, Ghandi

- "Letters from a Birmingham Jail," King

- Multiple choice practice

- The rhetoric of advertising

- Paper 4 - Comparison/Contrast Essay on the various interpretations of Civil Disobedience

5th Six Weeks - Synthesis - The American Dream

The American Dream is part of the romanticized notion of the United States: there is a promise of prosperity and success. Many works of American literature revolve around the attainment or the denial of this promise. We will read several pieces of American fiction that speak of this national ethos. The formal paper for this unit will be a synthesizing of elements from literature and non-fiction sources from previous units.

- Conception of the Dream: "Leaves of Grass," Whitman

- The struggle for the Dream: The Great Gatsby, Fitzgerald

- The Dream deferred: The Harlem Renaissance

- Sample AP essays

- Paper 5-Synthesis Paper

6th Six Weeks - Final Project

The last six weeks will focus on the writing of a major research paper utilizing one or more libraries as well as electronic media. As stated above, the paper will be based on a cultural, governmental, or social issue. Seven primary and secondary sources will be required, and the paper must be formatted in MLA style.

- Paper 6 - Issue-Based Research Paper

Plagiarism: Copying information off the Internet or taking a paper from someone else and claiming it as an original is considered plagiarism. This is a form of cheating that is taken very seriously by colleges and universities where plagiarism can result in expulsion from all classes. I do an Internet check on each paper turned into me. If I catch you plagiarizing, I will fail your for the assignment and insist that it be put on your permanent record so that your future college can be warned. Plagiarism is stealing, and in many cases cheaters have had to face criminal and civil court cases. You are AP students, and you have tremendous abilities. Use them!

Required Materials for Class: Your agenda book and ID are required to use the computer labs. You will also need to bring your books and journals to class every day.

\section{Grading Breakdown:}




\section{English}

Formal writing assignments $-40 \%$

Journals and informal writing $-20 \%$

Classwork and Assignments - $40 \%$

\section{JCPS Grading Scale}

\begin{tabular}{|c|c|c|}
\hline Letter grade & Percentage & Explanation \\
\hline $\mathrm{A}$ & $93-100$ & Exceeds Standards \\
\hline $\mathrm{B}$ & $86-92$ & Meets Standards \\
\hline $\mathrm{C}$ & $79-85$ & Marginally Meets Standards \\
\hline $\mathrm{D}$ & $70-78$ & Below Standards \\
\hline $\mathrm{U}$ & Below 70 & Unsatisfactory Performance \\
\hline
\end{tabular}

com: I keep a website where I post all assignments, due dates, original handouts, and research links. In the case of an absence, you can find out what the class covered at zom.

How to Reach Me: Both you and your parents can contact me through email. My address is . I read my mail at least three times per day. 


\section{SYLLABUS}

\section{Course Description}

This course engages students in becoming skilled readers of prose written in a variety of periods, disciplines, and rhetorical contexts and in becoming skilled writers who compose for a variety of purposes and audiences. Both their writing and their reading should make students aware of the interactions among writer's purpose, audience expectations, and subjects as well as how the generic conventions and the resources of language contribute to effectiveness in writing. Much of the class discussion will focus on the author's technique, meaning, and expression of philosophical ideas. Students should expect this course to be similar to an introductory college writing course that focuses on exposition, argument, and literary analysis.

\section{$\underline{\text { Standards }}$}

Upon completing this course students should be able to:

- Analyze and interpret samples of good writing, identifying and explaining an author's use of rhetorical strategies and techniques.

- Apply effective strategies and techniques in their own writing

- Create, sustain, and substantiate arguments based on readings, research, and/or personal experience.

- Show understanding and mastery of standard written English as well as stylistic maturity in their writing.

- Write for a variety of purposes.

- Produce expository, analytical, and argumentative compositions that introduce a complex central idea and develop it with appropriate evidence drawn from primary and/or secondary source material, cogent explanations, and clear transitions.

- Demonstrate understanding of the conventions of citing primary and secondary source material.

- Move effectively through the stages of the writing process, with careful consideration to inquiry and research, drafting, revising, editing, and review.

- Write thoughtfully about their personal writing process.

- Revise a work to make it suitable for a different audience and/or publication.

- Analyze image as text.

- Evaluate and incorporate reference documents into research papers.

- Analyze the historical and cultural development of American literature with insight and clarity.

- Write under time constraints.

- Read and analyze a minimum of six longer works of fiction in addition to the required summer reading.

\section{Textbooks}

The Language of Composition (2007) - by Renee H. Shea, Lawrence Scanlon, and Robin Dissin Aufses. Pub: Bedford / St. Martin's

Everyday Use: Rhetoric at Work in Reading and Writing (2005) - by Hephzibah Roskelly and David A. Jolliffe Pub: Pearson Longman

The Norton Reader: $11^{\text {th }}$ Edition (2004) — by Linda H. Peterson and John C. Brerton Pub: Norton

Literature: Reading Fiction, Poetry, Drama (and the Essay) (2006) - by Robert DiYanni

Write for College (2005) - by Patrick Sebranek Pub: McGraw-Hill (Glencoe)

Pub: Great Source Education Group

I will also provide you with handouts throughout the year to supplement our readings. These will include literary essays, criticism, historical documents, and study sheets.

\section{Material Required}

1 - Jump drive reserved for this class only

1 - Composition notebook for taking notes

1 - Folder / binder for handouts and returned work 


\section{Appendix C:}

1. Writing Completed in AP English Language and Composition

2. RAZOR Activity

3. Templates for Thesis Statements 


\section{Writing Completed in}

\section{AP English with}

\section{Writing to learn}

Research question/Idea dump

Warm-ups (about 26)

\section{Writing to demonstrate learning}

Summer reading diagnostic essay

12 AP free response practice essays

Annotated Bibliography

Summary of sides

RASAR for Friere \& hooks

RASAR for MLK's "Letter"

Analysis of professional analyses of MLK's "Letter"

Editorial Fridays \#1-5

RASARs for persuasive speech models

Compare/contrast Lincoln's "Gettysburg Address" \& JFK's "Inaugural Address"

"The Vietnam in Me" RASAR

Summaries for reflective writing models

2 K-PREP On-demand practices

Short answer responses on The Things They Carried test

\section{Writing for publication}

Personal essay

Position Paper

Researched argument paper

Persuasive speech

Satire

The Things They Carried literary analysis

Graphic novel analysis essay

Reflective writing

\section{Informative/Explanatory}

Summaries from RASARs and professional models

Summary of sides for researched argument paper

Annotated bibliography for researched argument paper

Letter to future students reflecting on the research paper (where applicable)

Literary analysis of The Things They Carried

Literary analysis of graphic novel 


\section{Narrative}

Personal essay

Researched argument paper (where applicable)

Persuasive speech (where applicable)

Satire (where applicable)

Reflective piece (where applicable)

\section{Argument}

WFP

Personal essay

Position paper

Researched argument paper

Persuasive speech

Literary analysis of The Things They Carried

Literary analysis of graphic novel

WTDL

2 K-PREP On demand practices

12 AP free response practice essays

\section{Writing that was peer workshopped}

Personal essay

Researched argument paper

Persuasive speech

\section{Writing that was self-scored}

12 AP free response essays

$2 \mathrm{~K}-\mathrm{PREP}$ On-demand writing practice

\section{Writing that required research \& documentation}

Summary of Sides

Position Paper

Researched argument paper

Persuasive speech

Literary analysis of The Things They Carried

Literary analysis of graphic novel (where applicable)

Satire final project (where applicable)

\section{Reflective writing}

Informal reflection of the first six-week grading period

Various informal reflections on summer reading essay \& free response practice

Letter to future students reflecting on the research paper

Informal reflection on satire final project

Informal reflection on improvement as a writer, especially on free response essays

Formal reflective piece (WFP) 


\section{Self-Assessment}

Summer reading essay

12 AP Free response questions

All writing for publication

\section{Editorial Fridays (5)}

RASARs on current editorials ( 2 conservative, 2 liberal, one centrist/apolitical)

\section{AP Free Response essays (12)}

Rhetorical analysis of Price's "Pink Plastic Flamingos" (2006; satire)

Argument on value of public opinion (2006)

Argument on Paine's characterization of America as it applies to today (2011)

Synthesis essay on the effect of TV on presidential elections

Rhetorical analysis (Queen Elizabeth's speech; unit quiz)

Argument of the ethics of incentives for charitable giving (2007; Free Response Friday)

Argument on the relationship between certainty and doubt (2012; Free Response Friday)

Rhetorical analysis on JFK speech (2012; Free Response Friday)

Synthesis about eliminating the penny (2008; Free Response Friday)

Synthesis about individuality \& conformity in schools (2009 Form B; Free Response Friday)

Synthesis on restructuring of the USPS (2012; Free Response Friday)

Rhetorical analysis (2009, question 2; satire unit quiz)

\section{RASARs}

Friere's "Banking Concept of Education"

hooks's "Toward a Feminist Pedagogy"

one of the 4 personal essay professional models

Martin Luther King's "Letter from Birmingham Jail"

Declaration of Independence???

Americanrhetoric.com top 5 speech

Tecumseh's "Broken American Promises"

Truth's “Ain't I a Woman" analyze one

Stanton's "Declaration of the Rights of Women"

McCarthy's witch hunt speech

Hitler's 1931 speech analyze one

Wallace's "Inaugural Address" (Segregation Now)

Malcolm X's "Ballot or the Bullet," just analysis

O'Brien's "The Vietnam in Me"

Swift's "A Modest Proposal"

The Onion's "Put Poor Students to Work," just analysis 


\section{Summaries}

Friere's "Banking Concept of Education"

hooks's "Toward a Feminist Pedagogy"

4 personal essay professional models: Mairs's "On Being a Cripple," Hurston "On Being

Colored," Didion's "On Going Home," Thoreau's "What I Lived for" from Walden

Martin Luther King's "Letter from Birmingham Jail"

Declaration of Independence???

Americanrhetoric com top 5 speech

Tecumseh's "Broken American Promises"

Truth's "Ain't I a Woman"

Stanton's "Declaration of the Rights of Women"

McCarthy's witch hunt speech

Hitler's 1931 speech

O'Brien's "The Vietnam in Me"

Swift's "A Modest Proposal"

Wallace's "Inaugural Address" (Segregation Now)

Gordon's "Putting Pen to Paper not Not Any Pen or Just Any Paper"

Haruf's "To See Your Story Clearly, Start by Pulling the Wool over Your Own Eyes"

Hiassen's "Real Life, That Bizarre and Brazen Plagiarist"

Mamet's "The Humble Genre Novel, Sometimes Full of Genius"

Proulx's "Inspiration? Head Down the Back Roads, and Stop for the Yard Sales"

Sontag's "Directions: Write, Read, Rewrite. Repeat Steps 2 and 3 as Needed"

Turow's "An Odyssey That Started with Ulysses"

Crews's Introduction to Classic Crews

O’Brien's "The Magic Show"

\section{Note-taking}

\section{HW}

Chapter 1, Informed Argument

Chapter 2, Informed Argument

Chapter 4, Informed Argument

Chapter 3, Informed Argument

Chapter 5, Informed Argument

Intro to rhetoric chapter, Classical Rhetoric for the Modern Student

Syllogism chapter, Classical Rhetoric for the Modern Student

Enthymeme chapter, Classical Rhetoric for the Modern Student

Chapter on Toulmin model from Everything's an Argument

\section{In-class}

Analytical writing defined

Personal essay as argument

Intro to rhetoric

Intro to syllogisms

Intro to enthymemes \& Toulmin model

Intro to Rogerian model

Intro to thesis statements

Intro to propaganda 
The Things They Carried

O'Gorman \& Calloway literary criticism of The Things They Carried

Student models of literary criticism of The Things They Carried

Graphic novel of student choice

Student models of graphic novel literary analysis (2)

Gordon's "Putting Pen to Paper not Not Any Pen or Just Any Paper"

Haruf's "To See Your Story Clearly, Start by Pulling the Wool over Your Own Eyes"

Hiassen's "Real Life, That Bizarre and Brazen Plagiarist"

Mamet's "The Humble Genre Novel, Sometimes Full of Genius"

Proulx's "Inspiration? Head Down the Back Roads, and Stop for the Yard Sales"

Sontag's "Directions: Write, Read, Rewrite. Repeat Steps 2 and 3 as Needed"

Turow's "An Odyssey That Started with Ulysses"

Crews's Introduction to Classic Crews

O'Brien's "The Magic Show"

Reflective writing student models (4)

Salinger's Catcher in the Rye

Steinbeck's Of Mice and Men

Research project student modeis

Annotated Bibliography

Various excerpts

Summary of Sides

Standardized testing

Physician-assisted suicide

Market in human organs

Position papers

Extraordinary rendition

Universal healthcare

Intelligent design

Final papers

Immigration

Public education

Stem cell research: effective \& adequate

Green business practices

Extraordinary rendition

Graded papers with comments

5 editorials

24 reading selections from six complete multiple choice exams

4 texts for AP free response rhetorical analysis essays

Student models for AP free response essays

AP multiple choice practice exams

$1991 \quad 2008$

19962010

2001 (twice) 2012

2007 


\section{Warm-ups}

1. How is everything an argument?

2. Discussion vs. debate

3. Rhetorical triangle, Bloom's taxonomy, pyramid of learning retention

4. What is analysis? What are the four elements of analysis? Why is it important to study analytical writing in high school?

5. What are the elements of an effective personal essay?

6. What is rhetoric? What does the general public associated with the term? What connotation does it have?

7. Research project intro: what are your fears, concerns? What have you heard about the project? What steps will help you be successful?

8. Reflection on the first six-week grading period

9. Statement by Alabama clergymen: reaction \& reevaluation of MLK's "Letter"

10. Mensa challenge \#1

11. Practice with syllogisms

12. Practice with syllogisms

13. Practice with enthymemes

14. Practice with enthymemes

15. Practice with enthymemes

16. Propaganda quotes: interpret \& react to one

A. What are the characteristics of an effective persuasive speech?

B. 3 open-ended questions \& 3 items to discuss for Tecumseh, Truth, \& Stanton

C. 3 open-ended questions \& 3 items to discuss for Hitler, Wallace, \& McCarthy

D. Mensa challenge $\# 2$

E. The Things They Carried intro: What do you associate with the Vietnam Era?

F. What is satire? How do we create satire? What are some examples of satire?

G. Reflection on satire unit: what are you still struggling with \& how can I help you?

$\mathrm{H}$. What are the elements of effective syntax?

I. Graphic novel intro: what comes to mind when you hear "graphic novel? Who reads them? What are they? Why read them in AP English Language?

J. What are the elements of effective diction? 
RASAR Strategy for Reading, Understanding, and Analyzing a Text.

-What is it about?

Annotate - What is important? Mark key words/phrases, important details, standout images, significant sentences, etc.. Make notes \& Ask questions - use the margins.

Summarize - How do you condense it? Use the things you marked to write a summary of what you read. Underline the things from your annotation and use page/line numbers.

Analyze - What Facts are most interesting and most important? What parts/Facts of this matter the most? What can you Infer? What Ideas come to mind? How does this information relate to other, similar, topics? Compare/Contrast? Cause-Effect?

Problem-Solution?

React - So What? Who Cares? Why does this matter in the bigger picture? Think Globally...

Critical Thinking Questions

(How and why/ universal and timeless/ critical, evaluative, analytical)

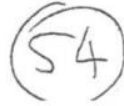


THE RHETORICAL ANALYSIS THESIS

\begin{tabular}{|l|}
\hline This is super-structured; yours may not look just like this - but will have similar parts. \\
\hline TOPIC: \\
\hline CLAIM [verb - look for CONTRAST (This is where you find complexity...)] \\
\hline DIRECTIONS (What? - Concrete) + ADJECTIVES (look on sheet!) \\
\hline 1. \\
\hline 2. \\
\hline 3. \\
\hline QUALIFIER/Bridge: \\
\hline UNIVERSAL IDEA / MEANING / Thematic Stmt (So What? - QUOTE?): \\
\hline WRITE FULL THESIS: \\
\hline
\end{tabular}

Abdion 15 


\begin{tabular}{|l|}
\hline \multicolumn{1}{|c|}{ THE ARGUMENT THESIS } \\
\hline NAYSAYER: \\
\hline TOPIC: \\
\hline CLAIM [verb]: Defend: \\
\hline DIIIENge: \\
\hline ADJECTIVES \\
\hline 2. \\
\hline 3. \\
\hline QUALIFIER: \\
\hline UNIVERSAL IDEA: \\
\hline WRITE FULL THESIS: \\
\hline
\end{tabular}




\section{Appendix D:}

1. The Great Gatsby Film Guide

2. F. Scott Fitzgerald Film Guide 


\section{Great Books: The Great Gatsby}

1) The story setting: summer, 192 NY.

Island

2) Gatsby lives in the town of West

3) Daisy has a green at the end of her dock.

4) Nick Carroway is the of the story.

5) Nick admires Gatsby's reinvention of

6) There are rumors of and in Gatsby's background.

7) Gatsby's large parties are meant to seduce

8) Gatsby is a veteran of (war)

9) Daisy is married is a bully.

10) People who cross Tom tend to

11) Nick is Daisy's , but he is also an outsider.

12) The Midwest is simple and

13) Myrtle Wilson thinks Tom embodies the

14) The Wilson's represent failure of the

15) The Wilson's live in the of

16) Doctor T. J. Eckleburg represents the of Gatsby's dream-landscape begins.

17) For Gatsby, the future is recapturing the Daisy were in love. when he and 
18) The green light represents infinite and

19) The green light can no longer be infinite possibility when Gatsby meets

20) Daisy's voice was full of

21) Gatsby captured the Age.

22) The 1920's had immigration problems, and The Great Gatsby is full of people with the wrong endings, who come from the wrong part of

23) Tom is rich and a

24) Gatsby's dreams run up against the of society.

25) When Tom reveals the source of Gatsby's wealth, the is over.

26) The Great Gatsby has been released in different languages.

27) when Myrtle is killed.

28) shoots for killing Myrtle. 


\section{F. Scott Fitzgerald Biography}

1. Francis Scott Key Fitzgerald was born in , MN.

2. He was a distant relative of the man who wrote the

3. F. Scott's father was a

4. F. Scott discovered early his gift for

5. He graduated from high school and attended University.

6. He wanted to be Big Man On Campus, but was cut the first day of practice from the team.

7. Fitzgerald showed the first signs of having a problem.

8. He was placed on probation for

9. Gevera King's father told him that girls. boys don't marry

10. he joined the Army and wanted to be a

11. He met Sayre at a dance, She came from a prominent family.

12. was wild.

13. ended before he was sent overseas.

14. He moved to New York to get a job and get

15. Zelda didn't want to marry him because he did not make much

16. Fitzgerald moved in with his and wrote his first novel, This Side Of Paradise.

17. The book was published and Fitzgerald was a hit at the age of 
18. Zelda changed her mind about

19. F. Scott was known as the King of The Zelda was known as the Queen of The

20. The Fitzgeralds were animals

21. F. Scott and Zelda's was expensive.

22. They moved to to escape the party scene.

23. They became part of a group of American artists known as the ex

24. F. Scott began working on a new novel,

25. He wrote many

26. Zelda had an with a French pilot.

27. F. Scott never got over the

28. The Great Gatsby was not a big

29. Fitzgerald met and began an intense rivalry.

30. The stock market Fitzgeralds' lives. mirrored the of the

31. Zelda slowly went

32. Zelda was diagnosed as (spell the way it sounds)

33. his next novel, was a flop.

34. Fitzgerald was drinking more now, averaging 30 beers a day, or a quart of

35. He was offered a job writing for the 
36. Shelia Graham, a gossip columnist, became his

37. Fitzgerald was let go from the movie company and has to was as a free writer.

38. His drinking became

39. He began writing a new novel as his health deteriorated.

40. Fitzgerald died of a at age 44

41. Few people came to his funeral including who was in poor health.

42. Zelda was killed in a at the age of 48 in an asylum.

43. The 1950's rediscovered F. Scott as one of the great of the twentieth century.

44. In 1996, St. Paul honored him with a commemorative on his $100^{\text {th }}$ birthday.

45. Some believe F. Scott knew he was

46. The Fitzgerlads' grandson himself. 


\section{Appendix E:}

1. Outcomes Met at the End of Developmental Writing

2. Charts showing Reading and English Growth-2013-2014

3. Paper Assignment \#1 
By fall 2012, the following learning outcomes will be included in developmental, transitional, and supplemental coursework and intervention programming supporting college readiness.

\section{WRITING}

Transitional, developmental, and supplemental education writing courses objectives:

1. Generate essays using a variety of modes to examine and convey complex ideas and information clearly and accurately through the effective selection, organization, and analysis of content.

2. Write arguments to support claims in an analysis of substantive topics or texts, using valid reasoning and relevant and sufficient evidence.

3. Produce clear, grammatically correct, and coherent writing in which the development, organization, style, usage, and diction are appropriate to task, purpose, and audience.

4. Develop and strengthen writing through the recursive processes of planning, drafting, revising, editing, or trying a new approach.

5. Use technology, including the Internet, to produce and publish writing and to interact and collaborate with others.

6. Conduct a short inquiry-based research project, demonstrating understanding of the subject under investigation.

7. Gather relevant information from multiple print and digital sources, assess the credibility and accuracy of each source, and integrate the information while avoiding plagiarism.

8. Write routinely over extended time frames (time for research, reflection, and revision) and shorter time frames (on demand or single sitting) for a range of tasks, purposes, and audiences.

Courses from public postsecondary institutions that meet the writing readiness learning outcomes:

KCTCS-ENC 091

Eastern Kentucky University-ENG 095

Kentucky State University-ENG 099

Morehead State University-ENG 099

Murray State University-ENG 100

Northern Kentucky University-ENGD 090

Western Kentucky University-DENG 055

University of Kentucky

University of Louisville 


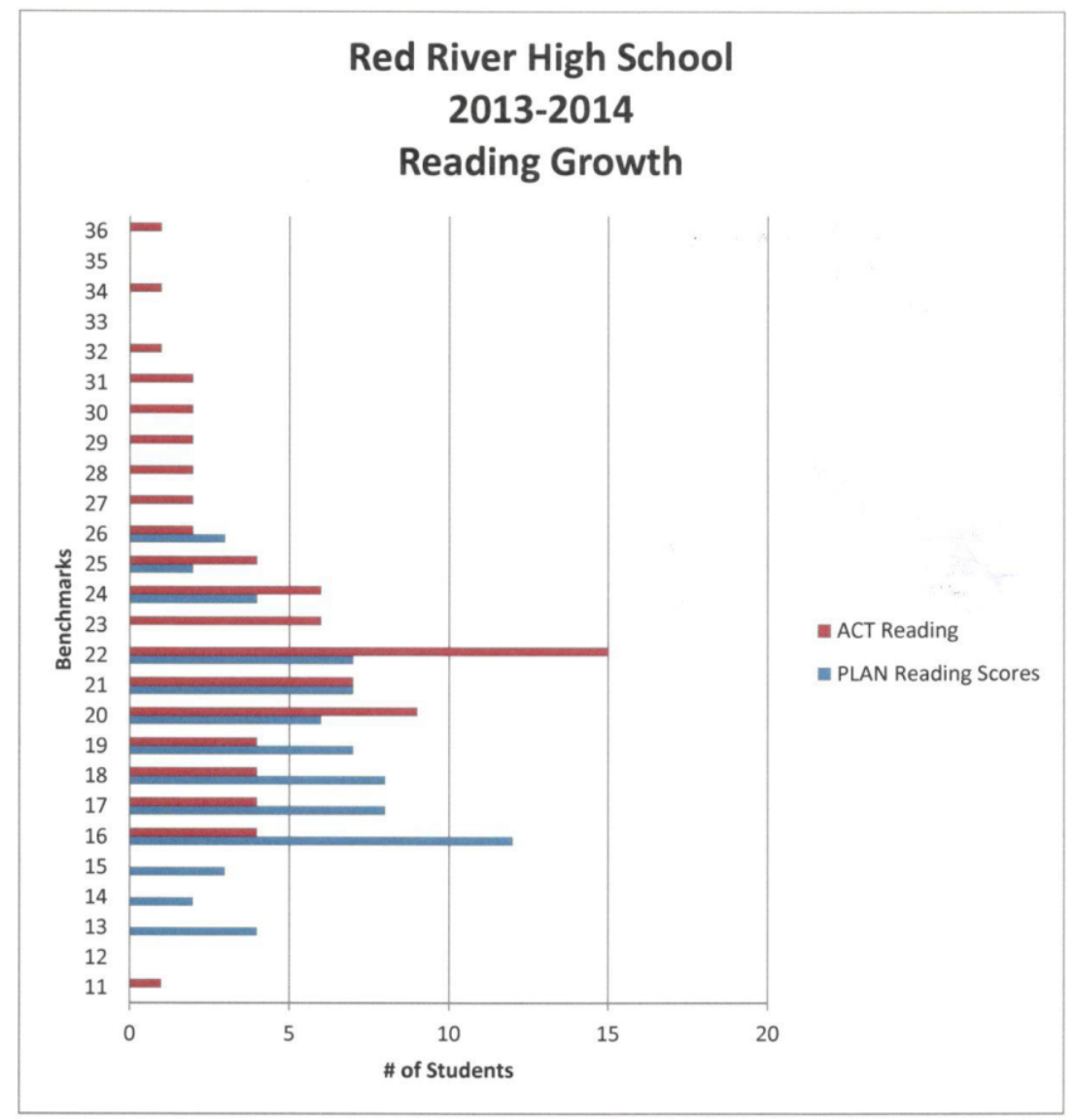




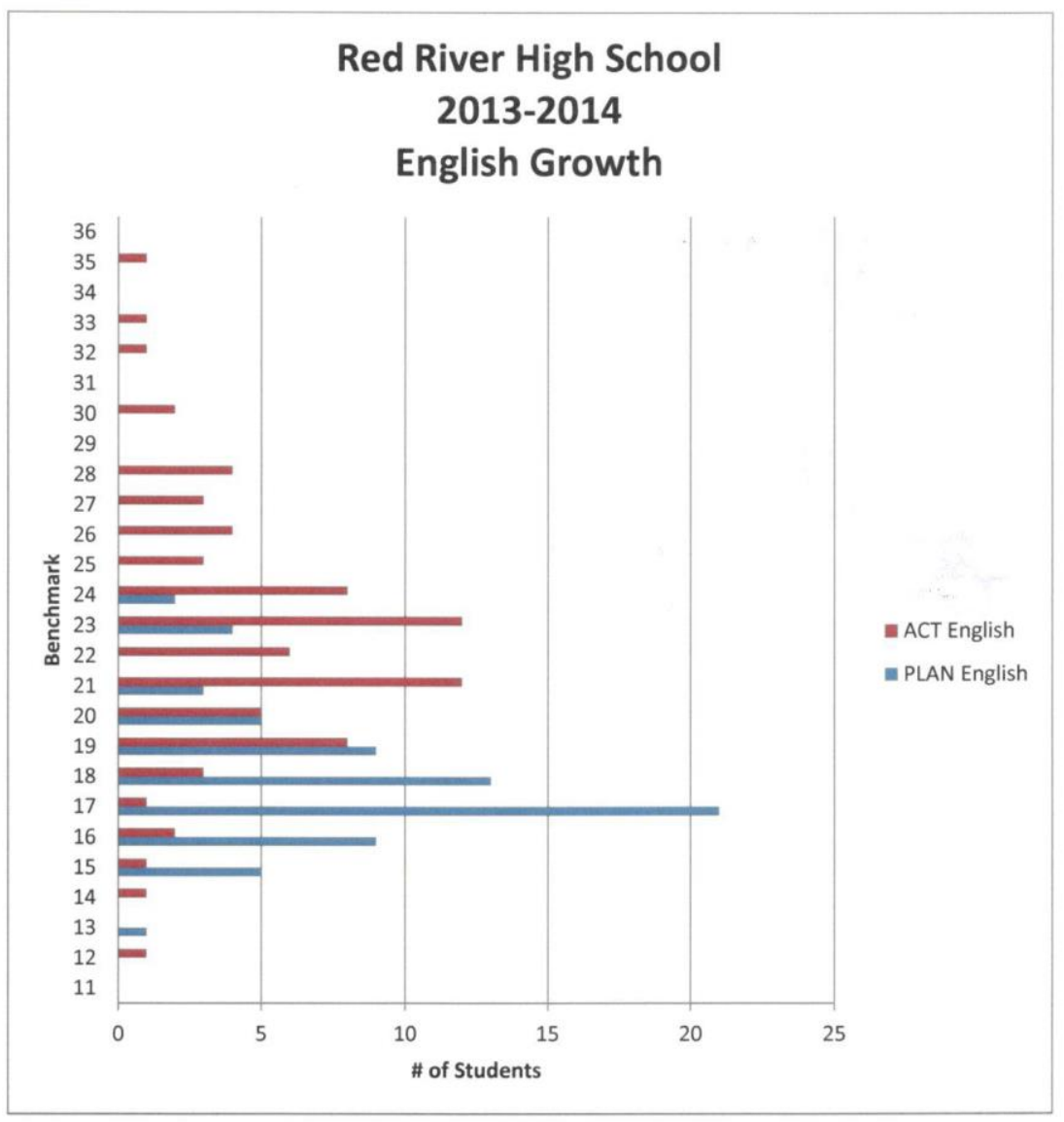




\section{Paper Assignment \#1}

"I Know Why the Caged Bird Cannot Read: How American High School Students Learn to Loathe Literature" and "A Talk to Teachers" synthesis essay

Due: Monday, September $16^{\text {th }}$

- This paper will be 3-5 pages - 12 pt. font - Times New Roman — double spaced.

Overview: Prose and Baldwin, if you distill their myriad ideas and sift through their many arguments, are essentially stating the same thing. It is your job to form a thesis that combines all these elements into one central argument.

Prompt: Francine Prose and James Baldwin both assert that the American education system is broken. While they both have very different approaches, they each share a disdain for how America's youth is being taught. In a 3-5 page essay, synthesize their ideas into one cogent, central thesis. Then, explain how they use rhetorical strategies to exemplify and support their shared claim.

Outline: The first paragraph should give a brief overview of each author's main arguments. Then provide a thesis sentence that states a synthesized, central thesis that both Prose and Baldwin would agree on. Note: The thesis statement should have three devices that are common for both Prose and Baldwin. Example: Prose and Balwin use , and to argue that

The second paragraph should discuss, in depth, either Baldwin's or Prose's argument as it relates to your thesis. Be sure to use plenty of evidence from the text that both identifies and explains his/her use of rhetorical devices to support your thesis. You should use at least three (3) examples of rhetorical devices used. Be sure to follow the format of analytical argument: statement, quote/evidence, explanation of quote, discussion of how quote/evidence proves/supports the thesis.

The third paragraph will be the same as paragraph 2, but it will address the other author.

The fourth paragraph will be a critique of how well they make their arguments. Think of the rhetorical triangle: How well do they engage their audience? How well do they use varying appeals? How well do they assert authority? Be sure to provide ample evidence to support your claims.

The fifth paragraph will deal with how their arguments could be improved. Neither Baldwin nor Prose effectively provides a solution to their stated problems. Going back to your central thesis, explain how this central problem in education could be solved. In short, this is your turn to posit a solution and argue for its effectiveness.

Reminder: Be sure to call or text me if you have any questions or get stuck...good luck! 


\title{
CURRICULUM VITAE
}

\author{
Hollye Nicole Wright \\ 5302 Mockingbird Valley Road \\ LaGrange, Kentucky 40031 \\ (502)592-2417 \\ hollye.wright@louisvlle.edu
}

\section{Education}

2011-2015

\section{University of Louisville}

Ph.D. in Rhetoric and Composition

- Dissertation: "Hidden Sites of 'First-Year' Composition: What Do We Mean When We

Say 'AP'? The Diversity of Practices in AP English Language and Composition Courses" (defended March 2015)

○ Committee: Bronwyn T. Williams (director), Mary P. Sheridan, Brenda Jo Brueggemann, Debra Journet, Dottie Willis

2008-2010

\section{University of Louisville}

\section{Master of Arts in English}

- Culminating Project: "Power Genre and the Church in the "Man of Law's Tale" and The Clerk's Tale"

o Director: Julia Dietrich

- Readers: Matthew Biberman and Andrew Rabin

2006-2008 University of Louisville

Master of Arts in Teaching-Secondary English with Middle Grades

\section{Extension}

2002-2006

University of Louisville

Bachelor of Arts in English-Magna Cum Laude

Bachelor of Arts in Humanities-Magna Cum Laude

- Thesis: "The Protest of Inequality and Oppression in the Harlem Renaissance as

Revealed in the Works of Langston Hughes, Zora Neale Hurston, and Billie Holiday"

○ Advisor: Michael Johmann

○ Readers: Tamara Yohannes and David Anderson

\section{Administration \& Research Experience}

Digital Media Academy for Girls

University of Louisville

March

2014-June 2015 
Assistant Director of Composition

University of Louisville June

2012-May 2014

Graduate Student Travel Administrator

University of Louisville May 2012-May 2013

Courses Taught

University of Louisville

Dual Credit English 101: Introduction to College Writing (5 sections)

English 101: Introduction to College Writing (3 sections)

Dual Credit English 102: Intermediate College Writing (5 sections)

English 102: Intermediate College Writing (6 sections)

English 306: Honors Business Writing (1 section)

English 309: Inquires in Writing (1 section)

English 310: Writing about Literature for Non-majors (1 section)

\section{Teaching Experience}

University of Louisville Composition Program

Fall 2011_Present_-Graduate Teaching Assistant

- Plan and implement instruction for a variety of writing courses, including

first-year composition, business writing, advanced writing, and writing about literature.

Fall 2010 - 2012 - Dual Credit Instructor

- Planned and implemented instruction for English 101: Introduction to

College Writing and English 102: Intermediate College Writing at

Louisville Male High School for advanced students.

Fall 2009-2011_Part-Time Faculty

- Planned and implemented instruction for English 101: Introduction to College Writing and English 102: Intermediate College Writing.

St. Aloysius Catholic School

October 2008 - 2011 - Substitute Teacher

South Oldham Middle School

Spring 2008-Student Teaching

North Oldham High School

Spring 2008-Student Teaching 
Fall 2007-40 hours of observation and classroom participation

\section{Grant Work}

Research Assistant-May 2011—January 2012

Collaborative Center for Literacy Development Small Research Grant—collected and coded data from initial teacher certification programs from eight public postsecondary institutions to gather statistics on teachers' literacy preparation.

Committee to Align FYC Outcomes with Common Core Standards-May 2011—August 2011

Recipient of the Professional Equity Project Grant-April 2010

To attend the Conference on College Composition and Communication in Atlanta as a Part-Time Faculty.

\section{Awards}

Graduate Student Spotlight at the University of Louisville—May 2013

The Carolyn Krause Maddox Prize in Women's \& Gender Studies—2012

$\$ 300$ award for one undergraduate student and one graduate student for the best papers on a topic in Women's \& Gender Studies.

Part-Time Lecturer Teaching Award-2011

Excellence in Teaching Award for Part-Time Lecturers in the Composition

Program

ETS Recognition of Excellence-2008

Outstanding score on The PRAXIS Series Principles of Learning and Teaching:

Grades $7-12$

Champions for Children-2007

from Jefferson County Public Schools

\section{Professional Development}

Kentucky Developmental Education Institute October 10, 2014

Commonwealth Commitment Summit February 27, 2013-March 1, 2013

Celebration of Teaching and Learning 2012-

Envisioning Teaching and Learning in the Digital Age

GTA Academy 2011-2012 
Part-Time Faculty Institute 2009-2010

Conference Presentations/Workshop Participation

Hollye Wright, (March 2015). Pre-College Credit for Writing, College Readiness and Pedagogical Innovation in AP English Language and Composition. Paper accepted at the Conference on College Composition and Communication in Tampa, Florida.

Hollye Wright, (November 2014). AP English Language and Composition and First-Year Writing: Practices, Pedagogies, and Theories. Poster Presentation at the National Council of Teachers of English Annual Convention in Washington, DC.

Hollye Wright, (October 2014). Aligning and Sponsoring: Responding to Students' Past and Future Writing Experiences. Paper accepted at The Thomas R. Watson Conference at the University of Louisville in Louisville, Kentucky.

Hollye Wright and Laura Determing, Ph.D. (May 2014). Promoting Critical Thinking in Informal and Formal Writing Assignments. Workshop Presentation at the 2014 Ideas to Action (i2a) Institute: Fostering a Community of Critical Thinking in Action at the University of Louisville in Louisville, Kentucky.

Robert Detmering, Laura Detmering, Ph.D. and Hollye Wright, (April 2014).

Twitterventions: Teaching Research-Based Writing and Information Literacy with

Twitter. Paper accepted for presentation at the 2014 Popular Culture Association Annual Conference in Chicago, Illinois.

Hollye Wright, (February 2014). Teaching Toni Morrison's Beloved in the High School English Classroom: An Analysis of Practice. Paper accepted at the Louisville Conference on Literature and Culture since 1900 in Louisville, Kentucky.

Hollye Wright, (October 2013). Incorporating the Symposium on Student Writing in Your Spring 2014 Course. Fall 2013 U of L Pedagogy Workshop in Louisville, Kentucky.

Hollye Wright, (June 2013). Transitions Matter: Moving from Writing in High School to Writing in College. Presentation at the Ohio Valley Educational Cooperative Summer Workshop at the University of Louisville in Louisville, Kentucky.

Hollye Wright, (June 2013). Helping Students Transition from High School to College Writing. Presentation at The English Teacher Connection Conference at Morehead State University in Morehead, Kentucky.

Hollye Wright, (March 2013). 3 Minute Thesis Presentation: Mr. Prezbo in HBO's "The Wire." Presentation at the Graduate Student Research Symposium at the University of Louisville in Louisville, Kentucky. 
Hollye Wright, (March 2013). Lessons Learned from a White Middle-Class Teacher in "The Wire." Paper accepted for presentation at the 2013 Popular Culture Association Annual Conference in Washington DC.

Hollye Wright, (October 2012). Laboring in Composition and Working Against the Feminization of the Discipline. Paper accepted for presentation at The Thomas R. Watson Conference at the University of Louisville in Louisville, Kentucky.

Laura Determing, Ph.D. and Hollye Wright, (September 2012). Using Workshops in the Composition Classroom, Fall 2012 U of L Pedagogy Workshop in Louisville Kentucky.

Hollye Wright, (March, 2012) Workshop Participant, 2012 Feminist Workshop of the CCCC in St. Louis Missouri.

Hollye Wright, (March, 2012). Arden of Faversham: Tragedy or Comedy? Paper accepted for presentation at the Kentucky Philological Association Meeting at Morehead State University in Morehead, Kentucky.

Nicole Fenty, Ph.D. and Hollye Wright, (October, 2011). Literacy in Teacher Education. Research findings presented at the Kentucky Reading Association Conference in Lexington, Kentucky.

Volunteer Work

March 2015

November 2013

June 2012-May 2013

Louisville

Spring 2012

Spring 2011
Volunteer for the Symposium on Student Writing

Attended the GTA Academy as an alumni mentor

Graduate Student Council at the University of

Co-organizer of the GSC Picnic

Worked SIGS Orientation to inform new graduate students of the serves provided by the GSC

Helped organize the GSC Christmas event 2012

Organized, set-up and worked the Graduate Student Symposium 2013

Graduate Student Mentor to perspective PhD students at the University of Louisville.

Internship with Louisville Free Public Library's Conversation Club 
Worked to organize, design, and implement English Language lessons for adult English Language Learners

October 2009-2011

Department Meetings

Fall 2009

Handbook at the University of

September 2008-May 2010

October 2008
Part-Time Faculty Representative to English

Committee to design the Part-Time Faculty

Louisville

St. Aloysius Catholic School

-implement small group literacy instruction

Watson Conference Technology Committee

\section{Graduate Coursework}

\section{Ph.D. Coursework}

English 620-Research in Composition

English 632-Shakespeare

English 670 - Composition Theory and Practice

English 671-History of Rhetoric I

English 673-Serial Narrative / Narrative Theory

English 674-Work In English

English 674-Interdisciplinary Rhetoric and Composition - Literacy

English 675-Studies in Professional Writing

English 681-Toni Morrison

English 686-Rhetoric of the Civil Rights Movement

English 687-Seminar in Rhetorical Studies-Ethnography

English 688-Watson Seminar

\section{M.A Coursework}

English 545-Study in British Literature-Romantic

English 561-Chaucer

English 601-Introduction to English Studies

English 602-Teaching College Composition

English 603-Studies in Genre: Film

English 631-Renaissance Drama

English $643-18^{\text {th }}$ Century Poetry and Prose

English 660-African American Literature

English 672-History of Rhetoric II

English 692-Queer Theory 


\section{Memberships}

College Composition and Communication

Golden Key International Honor Society

Honor Society of Phi Kappa Phi

National Council of Teachers of English

National Society of Collegiate Scholars

References available upon request 